\title{
Analysis and Experimental Qualification of an Irradiation Capsule Design for Testing Pressurized Water Reactor Fuel Cladding in the High Flux Isotope Reactor
}

Approved for public release. Distribution is unlimited.
Christian M. Petrie Richard H. Howard Kurt R. Smith Charles R. Daily

September 6, 2017 


\title{
DOCUMENT AVAILABILITY
}

Reports produced after January 1, 1996, are generally available free via US Department of Energy (DOE) SciTech Connect.

Website http://www.osti.gov/scitech/

Reports produced before January 1, 1996, may be purchased by members of the public from the following source:

\author{
National Technical Information Service \\ 5285 Port Royal Road \\ Springfield, VA 22161 \\ Telephone 703-605-6000 (1-800-553-6847) \\ TDD 703-487-4639 \\ Fax 703-605-6900 \\ E-mail info@ntis.gov \\ Website http://classic.ntis.gov/
}

Reports are available to DOE employees, DOE contractors, Energy Technology Data Exchange representatives, and International Nuclear Information System representatives from the following source:

Office of Scientific and Technical Information

PO Box 62

Oak Ridge, TN 37831

Telephone 865-576-8401

Fax 865-576-5728

E-mail reports@osti.gov

Website http://www.osti.gov/contact.html

\begin{abstract}
This report was prepared as an account of work sponsored by an agency of the United States Government. Neither the United States Government nor any agency thereof, nor any of their employees, makes any warranty, express or implied, or assumes any legal liability or responsibility for the accuracy, completeness, or usefulness of any information, apparatus, product, or process disclosed, or represents that its use would not infringe privately owned rights. Reference herein to any specific commercial product, process, or service by trade name, trademark, manufacturer, or otherwise, does not necessarily constitute or imply its endorsement, recommendation, or favoring by the United States Government or any agency thereof. The views and opinions of authors expressed herein do not necessarily state or reflect those of the United States Government or any agency thereof.
\end{abstract}


Reactor and Nuclear Systems Division

\title{
ANALYSIS AND EXPERIMENTAL QUALIFICATION OF AN IRRADIATION CAPSULE DESIGN FOR TESTING PRESSURIZED WATER REACTOR FUEL CLADDING IN THE HIGH FLUX ISOTOPE REACTOR
}

\author{
Christian M. Petrie \\ Richard H. Howard \\ Kurt R. Smith \\ Charles R. Daily
}

Date Published: September 6, 2017

\author{
Prepared by \\ OAK RIDGE NATIONAL LABORATORY \\ Oak Ridge, TN 37831-6283 \\ managed by \\ UT-BATTELLE, LLC \\ for the \\ US DEPARTMENT OF ENERGY \\ under contract DE-AC05-00OR22725
}





\section{CONTENTS}

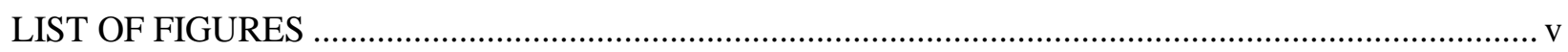

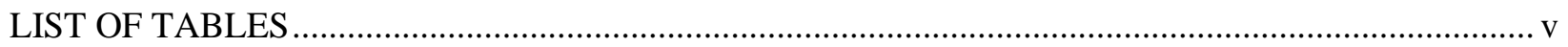

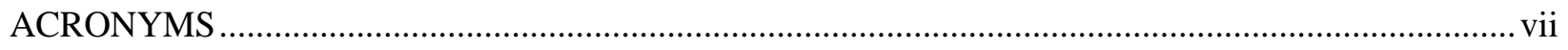

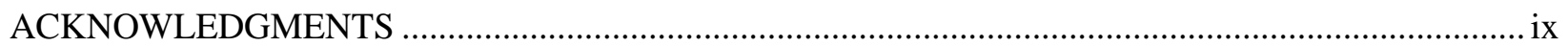

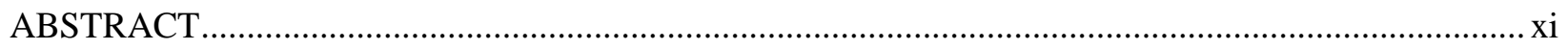

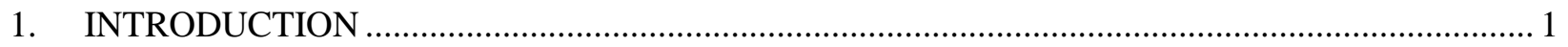

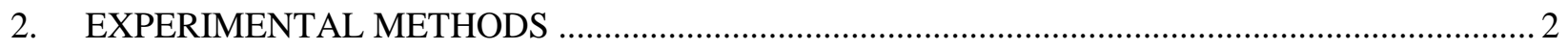

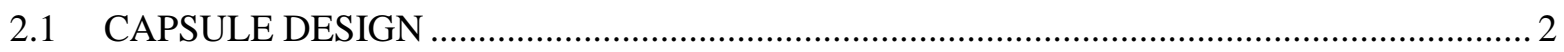

2.1.1 HFIR Irradiation and Experiment Design Concept............................................. 2

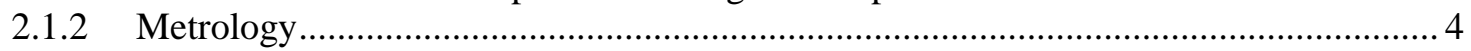

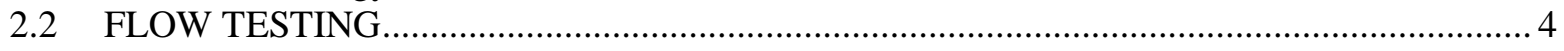

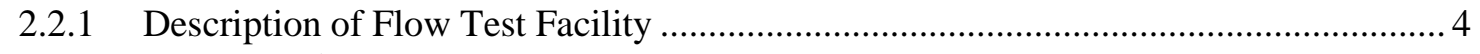

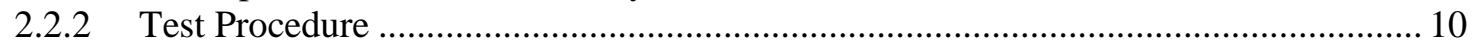

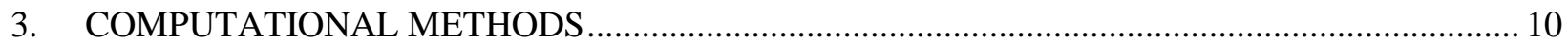

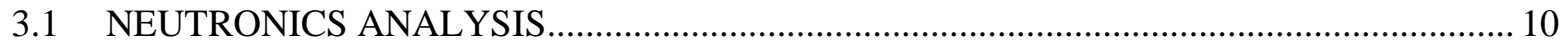

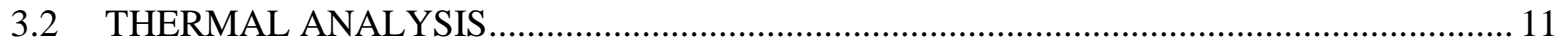

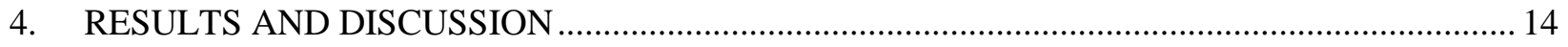

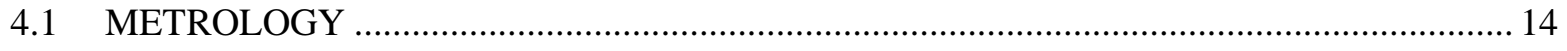

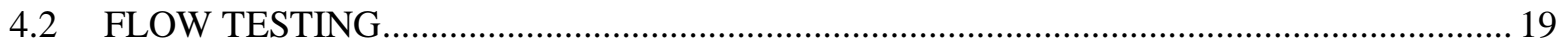

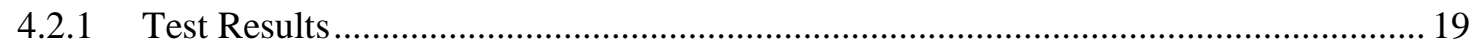

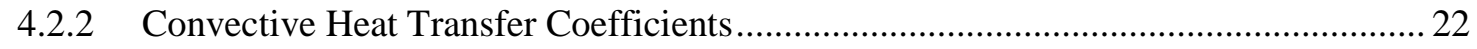

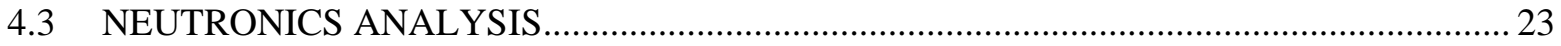

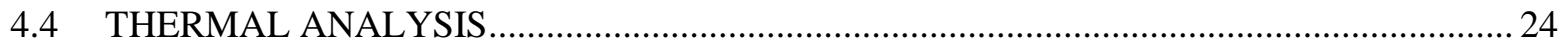

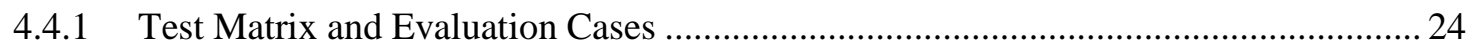

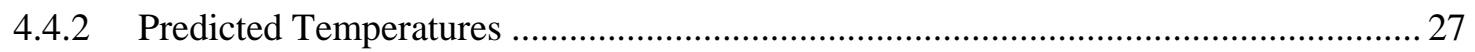

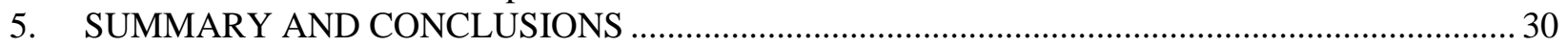

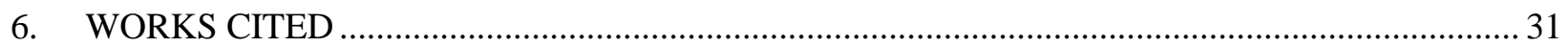

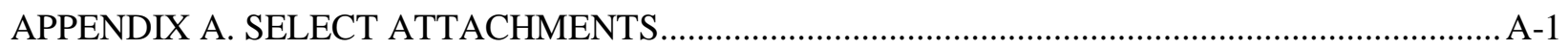

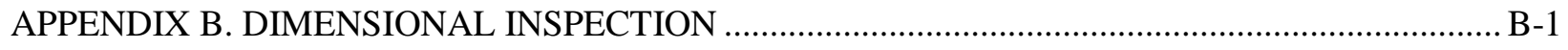

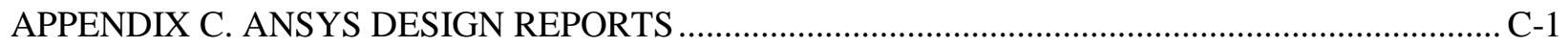





\section{LIST OF FIGURES}

Figure 1. Schematic (not to scale) showing transverse section view of HFIR core, reflector, and experimental positions.

Figure 2. Section view showing irradiation capsule design concept................................................ 3

Figure 3. Schematic of the WFL with test section to measure flow through a PTP holder loaded

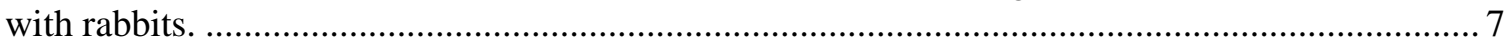

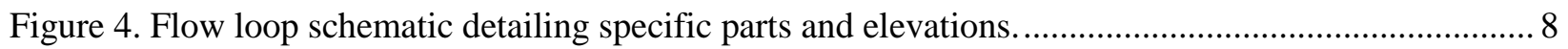

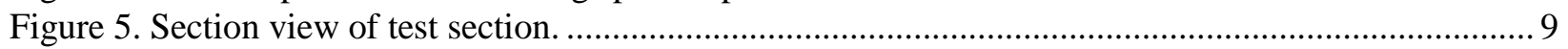

Figure 6. Flow rate and pressure drop data from one experiment and the corresponding steadystate subsets that were used to calculate average data points for each step in flow rate................ 10

Figure 7. Meshed 3D thermal finite-element model with $1 / 4$ symmetry.

Figure 8. Cladding outer diameter measurements for two FeCrAl specimens compared to the nominal $9.70 \mathrm{~mm}$ housing inner diameter. All $x$ and $y$ values are scaled such that they are $x$ and $y$ distances from some arbitrary reference radius that is unique to each specimen.

Figure 9. Cladding outer diameter measurements for two Zr-alloy specimens compared to the nominal $9.70 \mathrm{~mm}$ housing inner diameter. All $x$ and $y$ values are scaled such that they are $x$ and $y$ distances from some arbitrary reference radius that is unique to each specimen.

Figure 10. Measurements of one housing inner diameter at various axial locations as well as the nominal housing inner diameter. All $x$ and $y$ values are scaled such that they are $x$ and $y$ distances from some arbitrary reference radius that is unique to each specimen. ....................... 19

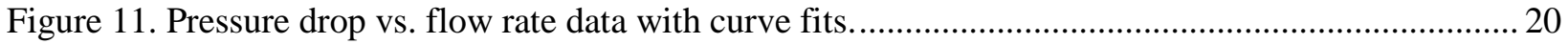

Figure 12. Pressure drop vs. dynamic pressure for Cases 1 and 2 ..................................................... 22

Figure 13. Temperature contours for the FCF04 rabbit assembly (left), bottom FeCrAl specimen (bottom right), and top $\mathrm{FeCrAl}$ specimen (top right).

Figure 14. Temperature contours for the FCZ03 rabbit assembly (left), bottom Zr-alloy specimen (bottom right), and top $\mathrm{Zr}$-alloy specimen (top right). .28

\section{LIST OF TABLES}

Table 1. Summary of the experiment assembly and part detail drawings............................................... 4

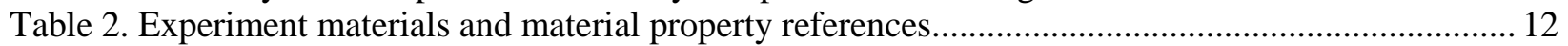

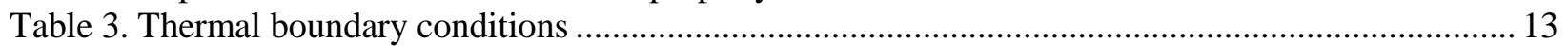

Table 4. Summary of average cladding dimensional measurements ........................................................ 15

Table 5. Summary of average housing dimensional measurements. ......................................................... 18

Table 6. Averaged flow and pressure drop data for the two tests that were performed ...........................20

Table 7. Flow areas and hydraulic diameters for the two experiment cases .......................................... 21

Table 8. Dynamic pressure and pressure drop (loss pressure) for the two experiment cases ................... 21

Table 9. Heat generation rates (W/g) for various materials at BOC and EOC in PTP and TRRH

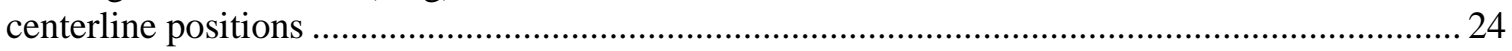

Table 10. Contributions to heat generation rates in experiment materials from various sources at BOC and EOC in PTP positions ....................................................................................... 24

Table 11. Irradiation test matrix, cladding specimen, housing, and sleeve pairing, gas gaps (using average cladding and housing dimensions), and gas mixtures for each rabbit ............................. 26

Table 12. Predicted cladding temperatures for each rabbit ...............................................................29

Table 13. Predicted passive temperature monitor (TM) temperatures for each rabbit............................... 30 



\section{ACRONYMS}

3D three dimensional

BOC beginning of cycle

CAD computer-aided design

DAC design and analysis calculations

DOE US Department of Energy

EOC end of cycle

HFIR High Flux Isotope Reactor

LWR light water reactor

MCNP Monte Carlo N-Particle

ORNL Oak Ridge National Laboratory

PIE post-irradiation examination

PTP peripheral target position

PWR pressurized water reactor

RB removable beryllium

$\mathrm{SiC} \quad$ silicon carbide

TRRH target rod rabbit holder

WFL water flow loop

$\mathrm{Zr} \quad$ zirconium 



\section{ACKNOWLEDGMENTS}

This research was sponsored by Advanced Fuels Campaign of the US Department of Energy (DOE), Office of Nuclear Energy. Neutron irradiation in the High Flux Isotope Reactor (HFIR) was made possible by the Office of Basic Energy Sciences, US DOE. The report was authored by UT-Battelle under Contract No. DE-AC05-00OR22725 with the DOE. The contributions of Kurt Terrani, the Oak Ridge National Laboratory program manager for Fuel Cycle Research and Development, are gratefully acknowledged. Kevin Field provided expertise in $\mathrm{FeCrAl}$ alloys. Mahmut Cinbiz performed the $\mathrm{Zr}$-alloy hydriding. Joel McDuffee offered helpful insights in the capsule design and reviewing the report. Yukinori Yamamoto was responsible for fabrication of the FeCrAl alloy tubes. Douglas Stringfield, Jordan Massengale, Frank Riley, and David Bryant assembled the irradiation capsules that will be irradiated in the HFIR. 



\begin{abstract}
The Advanced Fuels Campaign within the Fuel Cycle Research and Development program of the Department of Energy Office of Nuclear Energy is currently investigating a number of advanced nuclear fuel cladding concepts to improve the accident tolerance of light water reactors. Alumina-forming ferritic alloys (e.g., $\mathrm{FeCrAl}$ ) are some of the leading candidates to replace traditional zirconium alloys due to their superior oxidation resistance, provided no prohibitive irradiation-induced embrittlement occurs. Oak Ridge National Laboratory has developed experimental designs to irradiate thin-walled cladding tubes with representative pressurized water reactor geometry in the High Flux Isotope Reactor (HFIR) under relevant temperatures. These designs allow for post-irradiation examination (PIE) of cladding that closely resembles expected commercially viable geometries and microstructures. The experiments were designed using relatively inexpensive rabbit capsules for the irradiation vehicle. The simplistic designs combined with the extremely high neutron flux in the HFIR allow for rapid testing of a large test matrix, thus reducing the time and cost needed to advanced cladding materials closer to commercialization. The designs are flexible in that they allow for testing FeCrAl alloys, stainless steels, Inconel alloys, and zirconium alloys (as a reference material) both with and without hydrides. This will allow a direct comparison of the irradiation performance of advanced cladding materials with traditional zirconium alloys. PIE will include studies of dimensional change, microstructure variation, mechanical performance, etc. This work describes the capsule design, neutronic and thermal analyses, and flow testing that were performed to support the qualification of this new irradiation vehicle.
\end{abstract}





\section{INTRODUCTION}

Nuclear power produces approximately $20 \%$ of the electricity in the United States. Nearly all reactors that are either under construction or being considered in the short to near term are light water cooled and moderated. While traditional light water reactors (LWRs) with $\mathrm{UO}_{2}$ fuel and zirconium (Zr)-alloy cladding have a long history of successful operation, the accident tolerance of this fuel-cladding system has recently been questioned due to high-temperature steam oxidation, hydrogen generation, and radiation-induced embrittlement, particularly after the $\mathrm{Zr}$-alloy cladding forms hydrides [1-3]. In order to improve the accident tolerance of LWRs, a number of advanced nuclear fuel cladding concepts are currently being investigated $[4,5]$. These advanced cladding materials would provide enhanced fission product retention, slower high-temperature reaction kinetics with steam, reduced hydrogen generation, and improved thermomechanical properties. Of course performance under normal operating conditions including high fuel burnup, long fuel cycle length, and high reliability remain important for economic viability.

Some of the leading candidates to replace traditional Zr-based cladding are alumina-forming ferritic alloys (e.g., FeCrAl) [6-8]. FeCrAl alloys have shown superior oxidation resistance compared to $\mathrm{Zr}$ alloys, and they could also provide an additional margin for burst failure if they can retain superior hightemperature strength after irradiation. However, $\mathrm{FeCrAl}$ alloys are known to experience embrittlement under irradiation due to secondary-phase formations [9-11]. New information regarding the irradiation performance of $\mathrm{FeCrAl}$ alloys with representative LWR geometry and microstructure would be invaluable for qualifying these materials for use in commercial reactors. Ideally these materials would be irradiated in tube geometry at prototypic LWR temperatures $\left(300-350^{\circ} \mathrm{C}\right)$. Accelerated irradiation testing is preferred so that a large test matrix can be evaluated and down-selection of specific alloys and processing parameters can occur within a reasonable time and cost.

This report describes work that was done at Oak Ridge National Laboratory (ORNL) to develop and qualify experimental designs to irradiate thin-walled cladding tubes with the required LWR geometry and temperatures in the High Flux Isotope Reactor (HFIR). The design is flexible in that it can accommodate $\mathrm{FeCrAl}$ alloys, stainless steels, nickel (Ni)-based alloys, and Zr-based alloys (as reference materials) with an outer diameter $(9.50 \mathrm{~mm})$ equivalent to that of a $17 \times 17$ array pressurized water reactor $(\mathrm{PWR})$. Some advanced cladding materials would require reduced wall thickness (compared to traditional $\mathrm{Zr}$-alloy cladding) to reduce parasitic neutron absorption in the cladding. Therefore, the HFIR irradiation design can accommodate a range of cladding thicknesses from $0.3-0.7 \mathrm{~mm}$. The irradiated samples will allow the severity of the cladding degradation under irradiation to be determined through post-irradiation examination (PIE), which will include mechanical and microstructural evaluations. The experiments were designed using relatively inexpensive rabbit capsules for the irradiation vehicle. The simplistic designs combined with the extremely high neutron flux in the HFIR allow for rapid testing of a large test matrix. This work describes the capsule design, thermal and neutronic analyses, and other work such as flow testing to support experimental qualification in the HFIR. 


\section{EXPERIMENTAL METHODS}

\subsection{CAPSULE DESIGN}

\subsubsection{HFIR Irradiation and Experiment Design Concept}

\subsubsection{HFIR Irradiation}

The HFIR is a beryllium-reflected, pressurized, light water-cooled and moderated flux trap-type reactor located at ORNL [12]. The core consists of aluminum-clad involute-fuel plates, which currently use highly enriched ${ }^{235} \mathrm{U}$ fuel at a power level of $85 \mathrm{MW}$. A typical HFIR cycle is 25 days. The reactor core consists of two concentric annular regions, each approximately $61 \mathrm{~cm}$ in height. The flux trap region is located inside the fuel region. Moving radially outward from the fuel, there are control plates, a removable beryllium (RB) reflector, which includes $\mathrm{RB}^{*}$ irradiation facilities, and a permanent beryllium reflector with large and small vertical experiment facilities (VXFs). The water coolant for the reactor provides cooling for the fuel as well as for all experiment containments. The majority of experiments are conducted in the flux trap, typically in small, un-instrumented rabbit capsules, or less often in full length targets that span the entire length of the core. The flux trap has the highest fast and thermal neutron flux of all available facilities. As many as seven to nine rabbits can be stacked axially inside of a single peripheral target position (PTP) holder, a target rod rabbit holder (TRRH), or the hydraulic tube. The hydraulic tube allows short-term (less than a full cycle) irradiations to be performed. Orifices in the target rod and PTP holders allow for the outer surfaces of rabbits to be exposed to reactor coolant, which is approximately $50-60^{\circ} \mathrm{C}$. Positions are numbered in increasing order from bottom to top of a PTP or TRRH. Positions TRRH-4 and PTP-5 are closest to the reactor midplane (Figure 1).

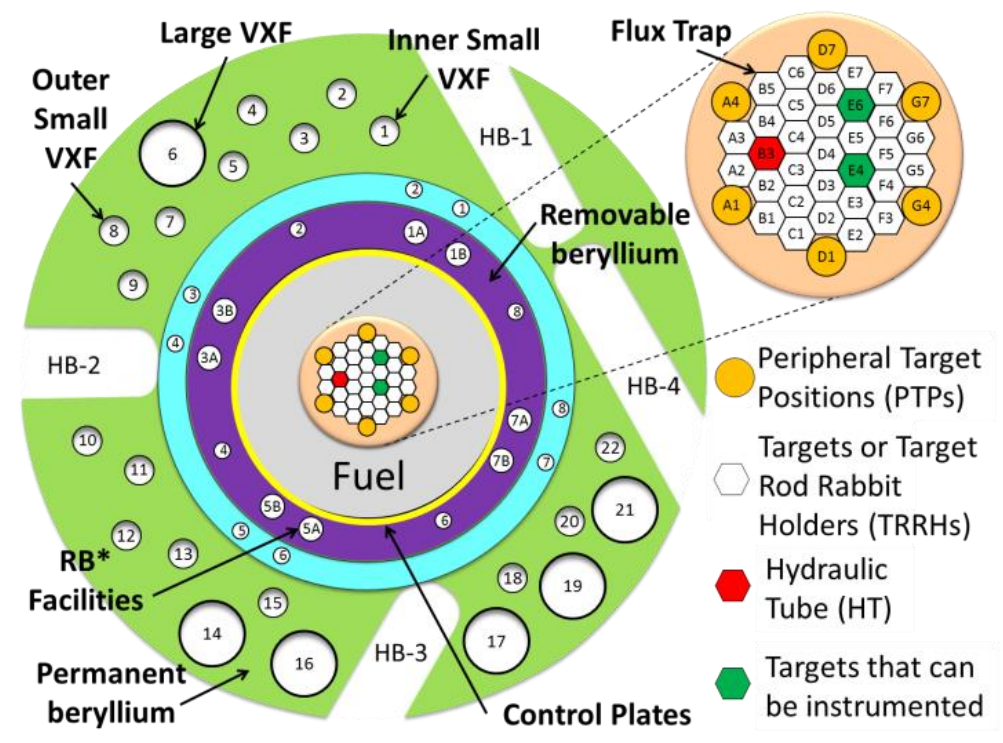

Figure 1. Schematic (not to scale) showing transverse section view of HFIR core, reflector, and experimental positions.

\subsubsection{Experiment Design Concept}

The goal of this work is to design an experiment to contain the cladding tube specimens inside a HFIRapproved irradiation vehicle so that they can accumulate the desired amount of radiation damage, or dose, while being irradiated at the design temperature. Neutron and gamma radiation from the HFIR fuel cause 
heating of the experiment materials. Heat generation rates are accurately determined using neutronics models of the HFIR core (Section 3.1) and are input to thermal models that are used to predict component temperatures during irradiation. As mentioned previously, experiments in the flux trap are almost always un-instrumented. Passive silicon carbide ( $\mathrm{SiC}$ ) temperature monitors, or thermometry, can be used to determine the irradiation temperature post-irradiation [13]. However, neutronic and thermal analyses are still required to ensure that the design temperatures are achieved. Section 3.2 summarizes the thermal models in more detail. However, the methodology is briefly discussed here so that the experimental design can be better understood. Typically HFIR irradiation experiments utilize a small insulating gas gap to achieve the desired component temperatures. The gap is established by the inner surface of the primary containment, which is actively cooled, and the outer surface of the internal components. The size of the gap and the choice of the fill gas (typically helium, neon, or argon) inside the experiment are chosen such that the heat generated in the experimental components passes through the gas gap, giving the desired temperature drop across the gap. The temperature drop is a function of the heat flux through the gap, the thermal conductivity of the fill gas, and the size of the gas gap.

The overall design of the irradiation experiments developed in this work is shown in the section views of Figure 2. Design drawings of the experiment assembly and part details are summarized in Table 1. The outer containment for the irradiation experiment is the rabbit capsule housing, which is directly cooled on the outer surface by the HFIR primary coolant. The cladding tube specimens are placed over molybdenum sleeves with slots on the inner surface and radial thru-holes drilled kat each end. In this design, the temperature is controlled by varying the concentration of a helium/argon gas mixture according to the measured size of the gas gap between the cladding and the housing. Varying the gas mixture changes the effective thermal conductivity of the gas gap. Centering thimbles are inserted inside the sleeves to keep the assemblies centered inside the housing and to maintain a constant gas gap between the cladding and the housing. Wires are inserted through the thimbles and the radial holes in the sleeves to keep the thimbles from being able to dislodge from the sleeves. Grafoil insulators are stacked on both ends of the capsule to reduce axial heat losses.

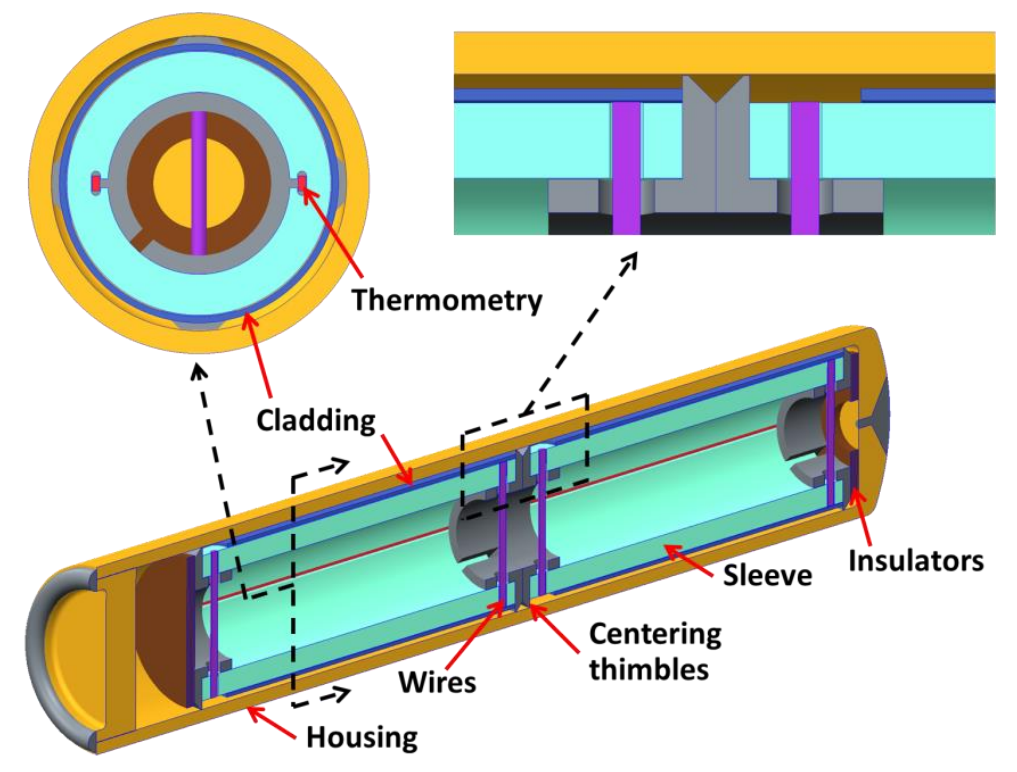

Figure 2. Section view showing irradiation capsule design concept. 
Table 1. Summary of the experiment assembly and part detail drawings

\begin{tabular}{|l|l|}
\hline \multicolumn{1}{|c|}{ Drawing } & \multicolumn{1}{c|}{ Title } \\
\hline X3E020977A689, Rev. 0 & Target Capsule Housing Assembly [14] \\
\hline X3E020977A690, Rev. 0 & Target Capsule Housing Details [15] \\
\hline X3E020977A634, Rev. A & Target Capsule Housing/End Cap Detail [16] \\
\hline S16-10-FLEXCLAD01, Rev. 0 & Flexible Cladding Rabbits Assembly [17] \\
\hline S16-11-FLEXCLAD02, Rev. 0 & Flexible Cladding Rabbits Assembly and Part Details [18] \\
\hline
\end{tabular}

\subsubsection{Metrology}

It is critically important that the temperature of the cladding tubes during irradiation be as close as possible to the temperature $\left(300-350^{\circ} \mathrm{C}\right)$ of fuel cladding in PWRs. As mentioned previously, the size of the gas gap is one of the parameters that determines the temperature drop through the gap. Therefore, very precise measurement of the cladding outer diameter and the housing inner diameter is required. Highprecision Mitutoyo 293-765-30 micrometers are used to measure the major and minor diameters (the cladding is circular but $\mu \mathrm{m}$-scale eccentricities are often observed) at five or six points along the length of the specimens, which are typically $15-23 \mathrm{~mm}$ long. Similarly, the inner diameter of the housing is measured at five axial locations using a Mitutoyo Crysta-Apex 920 coordinate-measuring machine (CMM) with Renishaw Modus 1.7 software. This level of detail is necessary to ensure that there are no significant eccentricities or axial variations in diameter that would affect the uniformity of the insulating gas gap.

\subsection{FLOW TESTING}

Standard HFIR rabbit housings (nominally $10.96 \mathrm{~mm}$ outer diameter, $9.52 \mathrm{~mm}$ inner diameter) are not large enough to accommodate $17 \times 17$ array PWR cladding tubes $(9.50 \mathrm{~mm}$ nominal outer diameter $)$ with a sufficiently large gas gap to control temperature. Therefore, this experiment required developing larger rabbit housings with nominal dimensions of $11.24 \mathrm{~mm}$ outer diameter and $9.71 \mathrm{~mm}$ inner diameter. The larger outer diameter of these new rabbits could potentially restrict flow through the channel between the rabbits and the PTPs or TRRHs in which the rabbits are contained during irradiation. Therefore, it was necessary to prove that adequate flow through the TRRHs could be achieved with a core pressure drop that is within the allowable range for HFIR operation. Engineering drawings of both the standard and large-bore rabbits are available upon request.

\subsubsection{Description of Flow Test Facility}

Flow testing was conducted at $22^{\circ} \mathrm{C}$ in the Water Flow Loop (WFL) facility, which is managed by the Thermal Hydraulics and Irradiation Engineering group at ORNL. A general schematic of the test loop is 
shown in

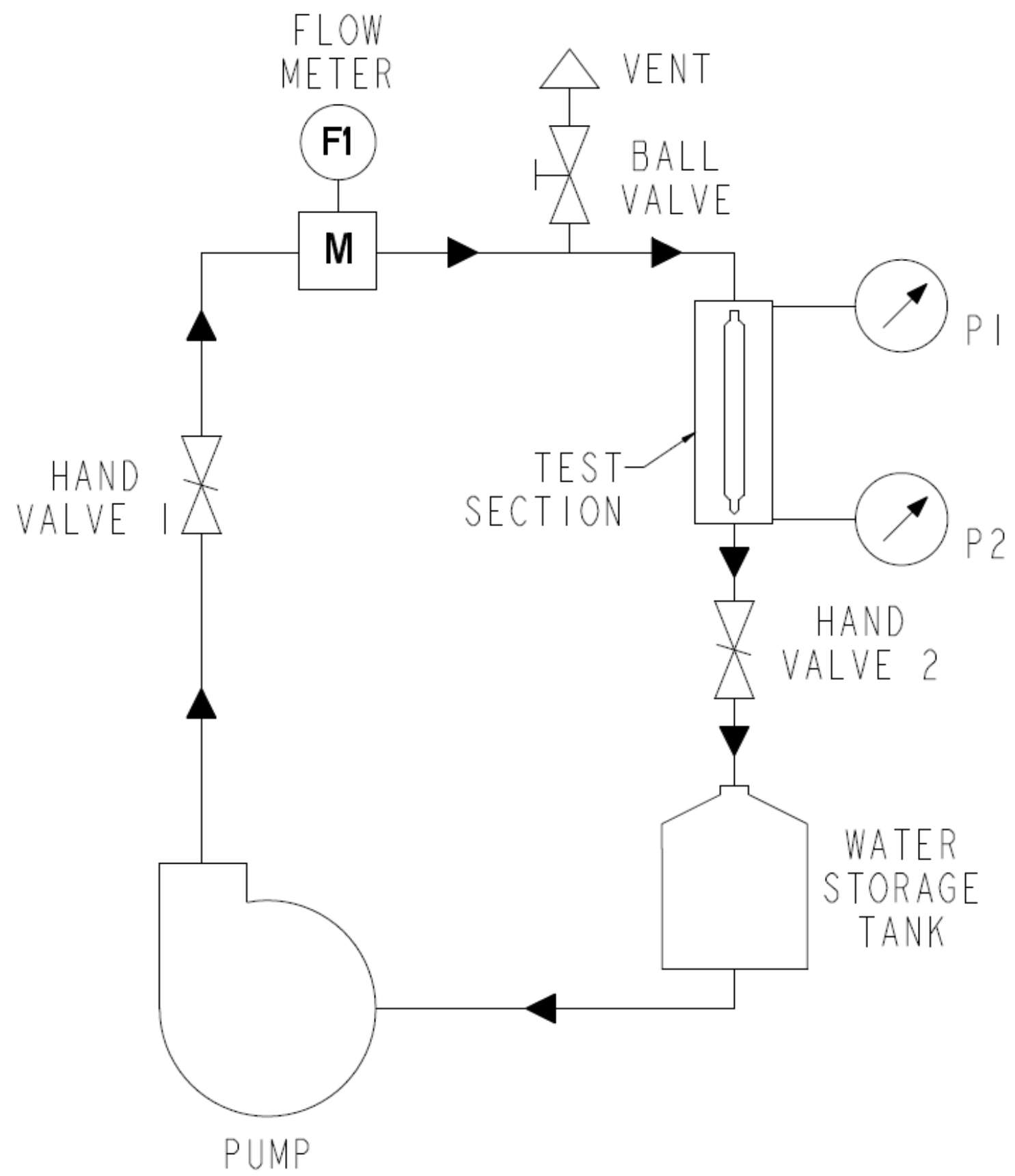

Figure 3. The WFL is essentially a pump and a water storage tank with a return line. A modular test region was added with hand valves in between the pump and the test section and between the test section and the water storage tank. In this experiment a PTP flow test section was used. Figure 4 and Figure 5 show computer-aided design (CAD) section views of the loop with the test section. A HFIR-issued PTP holder (serial number 11-02) was used for these tests. The PTP holder was loaded with a train of seven dummy rabbits (sealed rabbits containing aluminum slugs instead of cladding tubes and other experimental components) as shown in Figure 5. Both standard size and large-bore rabbits were tested. Dimensional inspection data for the dummy rabbits as well as other relevant information can be found in the attachments in Appendix A. Data on the PTP holder are available upon request. 
The WFL pump speed can be controlled using a variable frequency controller. A magnetic flowmeter (Azbil model MTG18A) was incorporated to measure the flow rate through the experiment. An Omegadyne DPG409-100DWU pressure gauge was used to measure pressure drop across the test assembly. Pressure measurements were taken at locations P1 and P2 as shown in Figure 4 and Figure 5. Engineering drawings of the PTP holder and the flow test section can be can be obtained by contacting the author. Calibration data for the pressure gauges and the flowmeter can be found in APPENDIX A, exhibits 1 and 2, respectively. The pressure gauge calibration data indicate that the maximum error observed over the entire calibration range $(0-689 \mathrm{kPa}$, or $0-100 \mathrm{psid})$ is $0.55 \mathrm{kPa}(0.08 \mathrm{psid})$. The flowmeter calibration data indicate a maximum error of $2.78 \mathrm{cc} / \mathrm{s}(0.044 \mathrm{gpm})$ over the testing range (roughly $210-610 \mathrm{cc} / \mathrm{s}$, or 3.33-9.67 gpm). It should be noted that the instrumentation was calibrated and set to acquire data in customary English units (psid and gpm, as is typically done for HFIR experiments). These data are later converted and reported in SI units. 


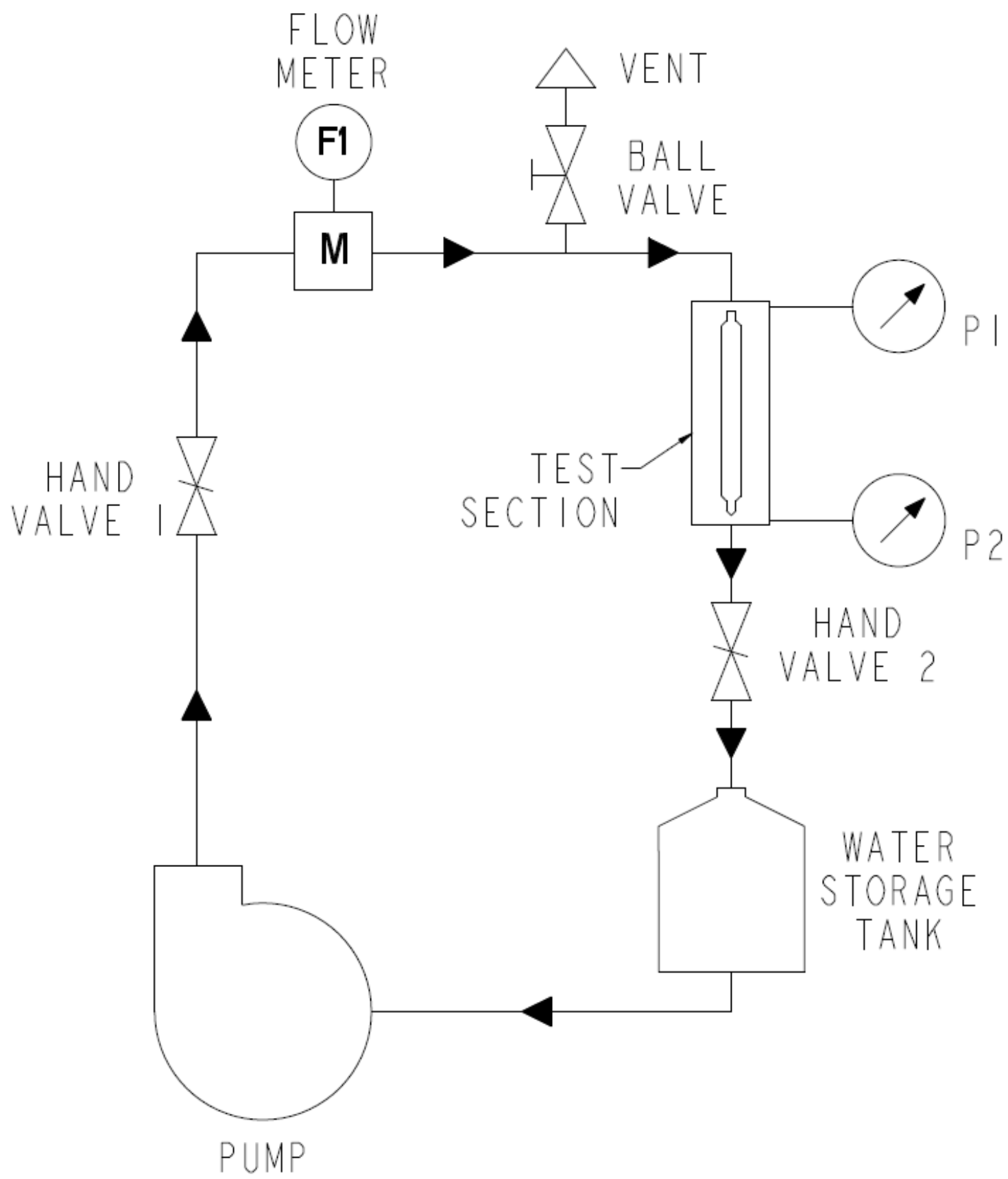

Figure 3. Schematic of the WFL with test section to measure flow through a PTP holder loaded with rabbits. 


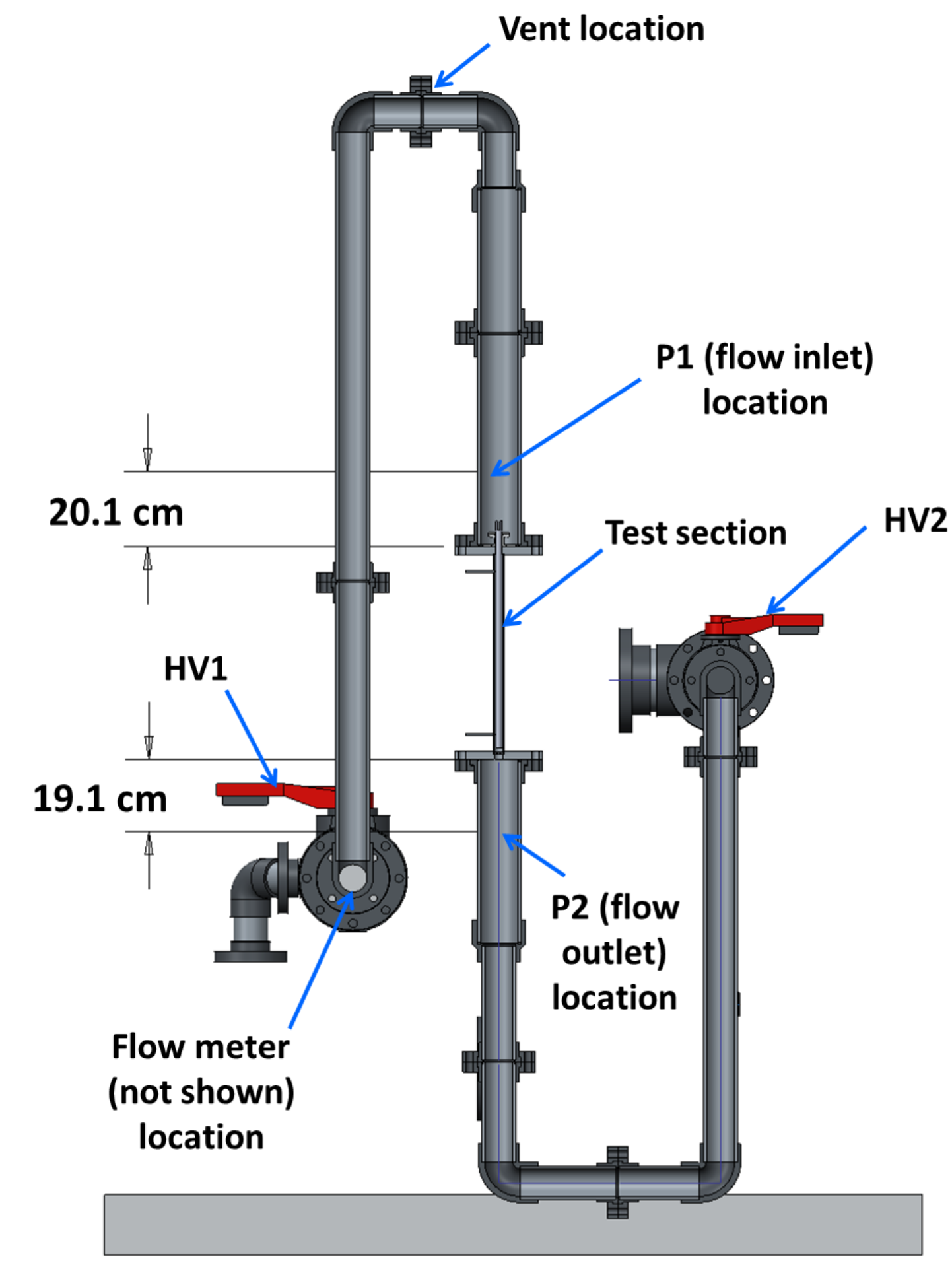

Figure 4. Flow loop schematic detailing specific parts and elevations. 


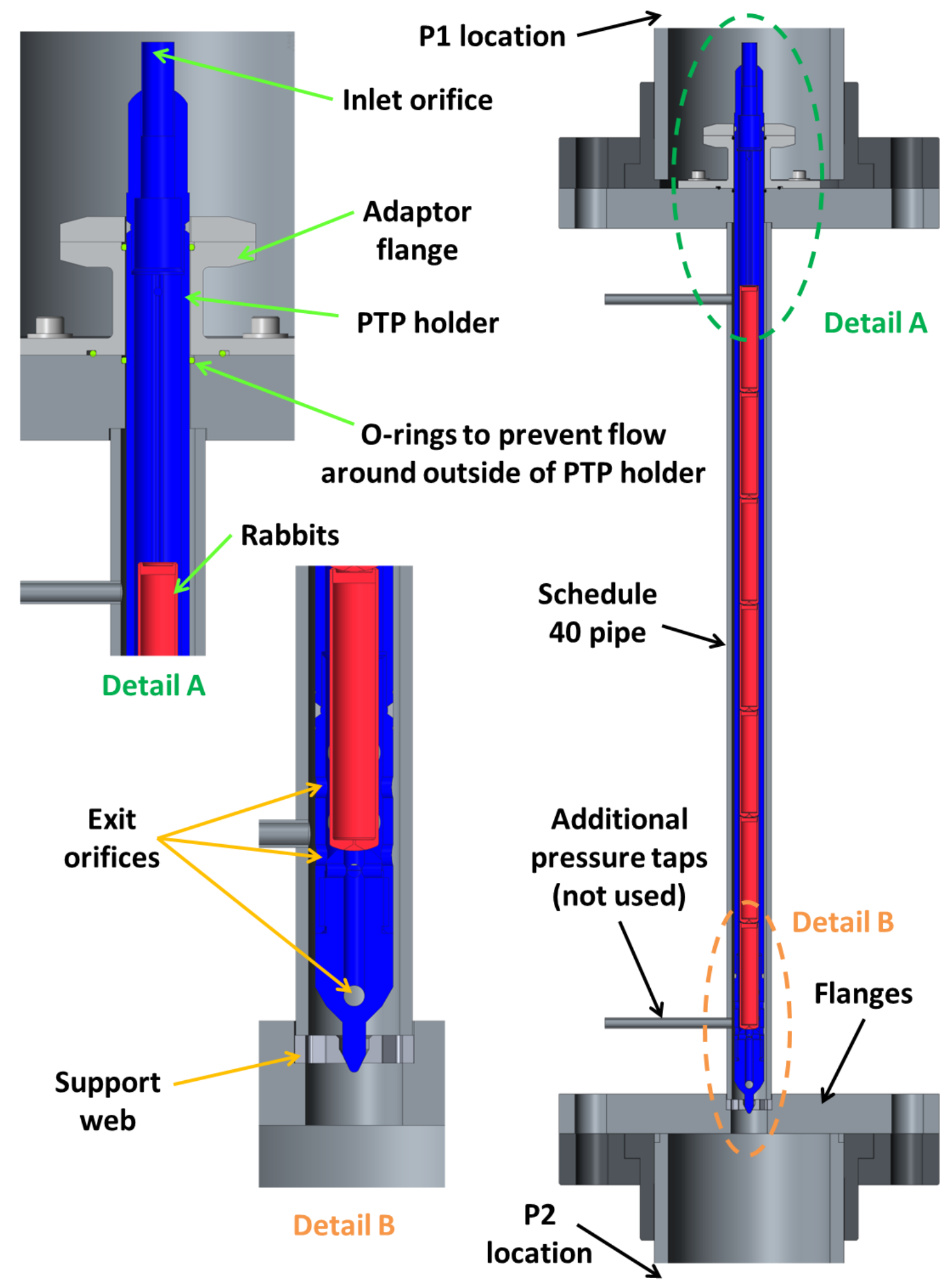

Figure 5. Section view of test section. 


\subsubsection{Test Procedure}

The facility was filled with water by starting the pump and circulating water through the test section and piping until no bubbles were observed exiting a bleed valve located at the top of the flow loop (Figure 4). Lines connecting the pressure gauges were also bled of air to ensure that all lines were full of water and free of air pockets. Flow testing was conducted by adjusting the pump speed to achieve the desired flow rate to the test section. The pump speed (and thus the flow rate) was increased in steps, and the system was allowed to reach a steady state after each increment in pump speed. Flow rates and pressure drops were recorded continuously using data acquisition software. The real-time data were verified against the gauge displays on both the pressure and flow rate readouts.

Steady-state measurements of pressure drop vs. flow rate were obtained by analyzing subsets of the data after a sufficiently long time after the pump speed was increased in each step. Small oscillations can be observed in both the pressure and flow rate data, so each data set was averaged over some time after reaching steady state. Figure 6 shows one example of data from an entire experiment and the corresponding steady-state subsets that were used to calculate average data points for each step in flow rate.

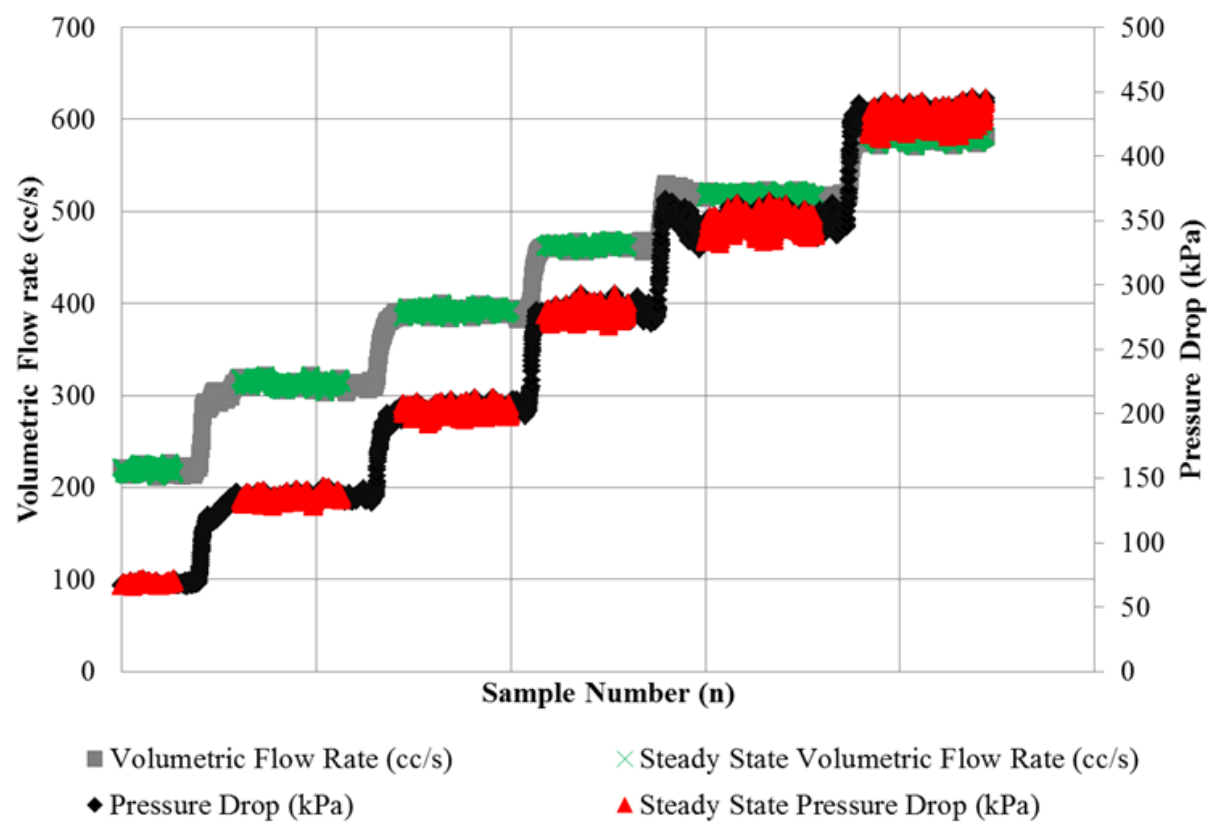

Figure 6. Flow rate and pressure drop data from one experiment and the corresponding steadystate subsets that were used to calculate average data points for each step in flow rate.

\section{COMPUTATIONAL METHODS}

\subsection{NEUTRONICS ANALYSIS}

Heat generation rates have four major components: (1) prompt neutron heating, (2) heating caused by fission photons and secondary photons produced by the fission neutrons (prompt photon heating), (3) heating due to fission product decay photons (fission product heating), and (4) heating due to the decay (primarily due to beta emission) of activation sources. Nuclear heating in HFIR is typically dominated by photon absorption in most materials. One exception is water, in which neutron scattering from hydrogen 
results in significant energy transfer to the scattered hydrogen nucleus, which produces substantial levels of neutron heat generation. Heat generation due to photon absorption is dependent on the atomic number of the absorbing element with higher-Z elements typically having higher heat generation rates due to increased pair production and photoelectric interactions. Photon absorption also depends on the magnitude and spectrum of the capture gammas released as a result of neutron absorption. For isotopes with a significant neutron absorption cross section, or at least one or more large resonance absorption peaks, the heat generation within the sample can be significantly affected by the shape of the specimen. This is because these isotopes often de-excite to their ground state by emitting a cascade of lower energy photons following neutron absorption. The low-energy photons may or may not deposit their energy locally in the material, depending on the component geometry.

Because of the geometric dependence of heat generation in some materials, the rabbit geometry was explicitly modeled using the Monte Carlo N-Particle (MCNP) to determine neutron and gamma heat generation rates in the experimental components including the aluminum housing, cladding tubes (FeCrAl and Zircaloy-4), and the molybdenum sleeves. The model does not consider minor components such as $\mathrm{SiC}$ thermometry, centering thimbles, wires, insulator disks, etc. The MCNP models of the HFIR core at beginning of cycle (BOC) and end of cycle (EOC) were developed previously [19]. These models include variations in fuel composition, control plate position, and fission density within the fuel at the two extremes of a HFIR cycle. Further modifications were made to these models to calculate heat generation rates. Prompt neutron and photon heating are modeled in MCNP. Fission product photon heating is also modeled in MCNP using a fixed photon source distributed throughout the HFIR fuel. The photon energy spectrum and steady-state photon yields for fission product decay photons were calculated using the ORIGEN software package. Heating due to local alpha and beta decay of components is also calculated using ORIGEN assuming 100\% local energy deposition.

\subsection{THERMAL ANALYSIS}

Three-dimensional (3D) thermal analyses are performed using the ANSYS finite-element software package to predict temperature distributions inside the experiment. These analyses use material-dependent heat generation rates (heat per unit mass) calculated from the neutronics analyses as inputs. Custom userdefined macros were incorporated into ANSYS to determine thermal contact conductance between components either in contact or separated by small gas gaps that expand or contract due to thermal expansion [20]. In this way, gas gaps are not directly meshed, which significantly reduces computational time. CAD models are imported into ANSYS and meshed. Thermal contacts are defined to allow heat to be transferred between multiple bodies. Gas gap heat transfer is assumed to only include conduction as there is very little space available for natural convection to occur. Gaps are typically on the order of microns to a few millimeters, and the total internal length of the capsule is less than $60 \mathrm{~mm}$. The solver accounts for thermal expansion using temperature-dependent thermal expansion data and the temperatures of contact and target surface nodes.

The ORNL Thermal Hydraulic and Irradiation Engineering Group maintains a database of design and analysis calculations (DACs) that includes temperature-dependent (and in some cases radiation dosedependent) thermophysical material properties that are used in thermal analyses. Properties are primarily obtained from CINDAS [21], MatWeb [22], and various literature sources. Properties of gas mixtures are calculated using the methods described by Wahid et al. [23]. Material properties for this calculation are included in the DACs shown in Table 2, which are available upon request. 
Table 2. Experiment materials and material property references

\begin{tabular}{|l|l|l|}
\hline \multicolumn{1}{|c|}{ Part } & \multicolumn{1}{c|}{ Material } & \multicolumn{1}{c|}{ Reference } \\
\hline Housing, end cap & Aluminum & DAC-10-03-PROP_AL6061 [24] \\
\hline Cladding & FeCrAl & DAC-16-02-PROP_FeCrA1 [25] \\
\hline Cladding & Zircaloy-4 or ZIRLO & DAC-11-03-PROP_ZIRCALOY [26] \\
\hline Centering thimbles & Grade 5 titanium & DAC-11-14-PROP_TI6AL4V [27] \\
\hline Insulators & Grafoil & DAC-11-16-PROP_GRAFOIL [28] \\
\hline Thermometry & Silicon carbide & DAC-10-06-PROP_SIC(IRR) [29] \\
\hline Sleeves and wires & Molybdenum & DAC-10-11-PROP_MOLY [30] \\
\hline Fill gas & Argon & DAC-10-09-PROP_ARGON [31] \\
\hline Fill gas & Helium & DAC-10-02-PROP_HELIUM [31] \\
\hline
\end{tabular}

Convection boundary conditions are applied to the outer surface of the housing. Details of the calculation of the convective heat transfer coefficients and bulk coolant temperatures are summarized in DAC-11-01RAB03 [32]. These parameters were calculated using turbulent flow correlations and the axial power profile (due to neutron and gamma heat generation in the coolant) specific to TRRHs in the HFIR flux trap. The temperatures calculated in the thermal analyses are not extremely sensitive to the convection heat transfer coefficient, as the housing surface temperatures are typically only $\sim 10^{\circ} \mathrm{C}$ warmer than the bulk coolant temperature.

The heat generation rates vary in each irradiation location (PTP vs. TRRH) and as a function of axial position from the midplane of the reactor core. Peak heat generation rates (at the core midplane), parameters for determining the axial profile, and convection parameters are summarized in Table 3. Some minor components were not explicitly included in the neutronics calculations described in Section 3.1. However, similar calculations were performed previously $[33,34]$ for other experiments that included the materials that make up these minor components. Results from these previous calculations were used in the analyses for this experiment for materials that were not explicitly modeled in the neutronics analysis. Although the geometries for previous experiments were different, the results are on a per-unit-mass basis, and therefore they provide a reasonable estimate of heat generation in this experiment. Aluminum heat generation rates were not modified based on whether the cladding was made of $\mathrm{FeCrAl}$ or Zircaloy-4. Minor discrepancies in aluminum heat generation rates with $\mathrm{FeCrAl}$ vs. Zircaloy-4 cladding were observed due to differences in attenuation of gammas that pass radially through the cladding and then generate heat in the aluminum housing on the opposite side. Aluminum heat generation rates between those calculated for $\mathrm{FeCrAl}$ and Zircaloy-4 cladding were used. This resulted in at most a $0.6 \mathrm{~W} / \mathrm{g}$ discrepancy, which has little effect on component temperatures because all of the heat generated in the aluminum housing is dissipated to the reactor coolant and does not affect internal temperatures. 
Table 3. Thermal boundary conditions

\begin{tabular}{|l|c|c|}
\hline \multicolumn{1}{|c|}{ Parameter } & Value in PTP & Value in TRRH \\
\hline Heat transfer coefficient & $48.4 \mathrm{~kW} \mathrm{~m}^{-2} \mathrm{~K}^{-1}$ & $47.1 \mathrm{~kW} \mathrm{~m}^{-2} \mathrm{~K}^{-1}$ \\
\hline Bulk coolant temperature & $54^{\circ} \mathrm{C}$ & $52^{\circ} \mathrm{C}$ \\
\hline Peak heat generation rate for aluminum & $29.9 \mathrm{~W} / \mathrm{g}$ & $28.8 \mathrm{~W} / \mathrm{g}$ \\
\hline Peak heat generation rate for titanium & $35.6 \mathrm{~W} / \mathrm{g}$ & $35.2 \mathrm{~W} / \mathrm{g}$ \\
\hline Peak heat generation rate for FeCrAl & $34.4 \mathrm{~W} / \mathrm{g}$ & $33.5 \mathrm{~W} / \mathrm{g}$ \\
\hline Peak heat generation rate for Zr-alloys & $46.1 \mathrm{~W} / \mathrm{g}$ & $45.1 \mathrm{~W} / \mathrm{g}$ \\
\hline Peak heat generation rate for SiC & $34.0 \mathrm{~W} / \mathrm{g}$ & $32.9 \mathrm{~W} / \mathrm{g}$ \\
\hline Peak heat generation rate for grafoil & $35.0 \mathrm{~W} / \mathrm{g}$ & $33.7 \mathrm{~W} / \mathrm{g}$ \\
\hline $\begin{array}{l}\text { Peak heat generation rate for molybdenum } \\
\text { with FeCrAl cladding }\end{array}$ & $43.6 \mathrm{~W} / \mathrm{g}$ & $42.5 \mathrm{~W} / \mathrm{g}$ \\
\hline $\begin{array}{l}\text { Peak heat generation rate for molybdenum } \\
\text { with Zr-alloy cladding }\end{array}$ & $41.0 \mathrm{~W} / \mathrm{g}$ & $39.8 \mathrm{~W} / \mathrm{g}$ \\
\hline Correlating parameter $(\sigma)$ & $30.07 \mathrm{~cm}$ \\
\hline Note: PTP = Peripheral Target Position, TRRH Target Rod Rabbit Holder \\
\hline
\end{tabular}

The local heat generation rate is estimated with the following profile:

$q($ material,$z)=q_{\text {peak }}($ material $) \cdot \exp \left[-\left(\frac{z}{\sigma}\right)^{2}\right]$

where
$q=$ local heat generation rate as a function of the material and axial location, $q_{\text {peak }}=$ heat generation rate at the HFIR midplane as a function of material,
$z=$ axial location in the HFIR, where the midplane is at $\mathrm{z}=0$, and
$\sigma \quad=$ correlating parameter.

Figure 7 shows one example of a fully meshed 3D finite-element model. The model utilizes $1 / 4$ symmetry to reduce computational time. The majority of the components were meshed using 20 node hexagonal elements with a mesh size of $0.3 \mathrm{~mm}$. The centering thimbles and housing end cap used 20 node tetrahedral elements. The housing and end cap used mesh sizes of 0.5 and $0.7 \mathrm{~mm}$, respectively. As-built specimen, sleeve, and housing dimensions obtained from metrology were used in the model to give the best estimates of component temperatures.

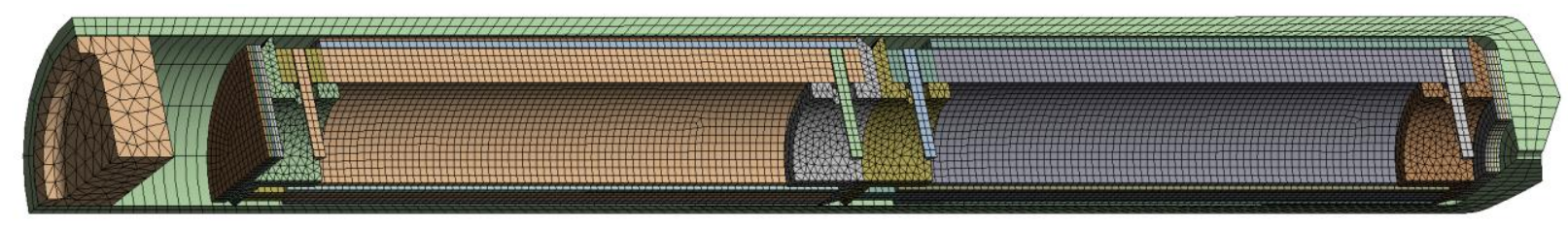

Figure 7. Meshed 3D thermal finite-element model with $1 / 4$ symmetry. 


\section{RESULTS AND DISCUSSION}

\subsection{METROLOGY}

As mentioned in Section 2.1.2, high-precision dimensional inspection of the cladding specimens and the capsule housings was necessary to ensure that the cladding-to-housing gas gap, which is used to control temperature, is uniform around the circumference of the cladding. Table 4 summarizes average dimensional measurements for all cladding specimens that were included in the irradiation experiments. The average gas gap is calculated using the averaged measured housing inner diameter and the cladding/housing pairing that is introduced later in Section 4.4. Figure 8 and Figure 9 show examples of the cladding outer diameter measurements that were made. The $x$ and $y$ values are scaled such that they are $x$ and $y$ distances from some reference radius (arbitrarily defined as 99\% of the minimum measured inner radius of the cladding) that is unique to each specimen. This allows one to observe the variations in the cladding outer diameter at various axial locations $(z)$ compared to the nominal housing inner diameter of $9.70 \mathrm{~mm}$. Both the cladding outer diameter values and the nominal housing inner diameter are scaled to the same reference radius.

Figure 8 shows that specimen B136Y-4 has a very uniform outer diameter along the entire axis. Specimen C06M-02 has more significant variation in diameter, particularly at one end $(\mathrm{z}=0 \mathrm{~mm})$. Because this nonuniformity would only affect temperatures at the end of the specimen, specimen C06M-02 was considered acceptable. Using similar logic, specimen Zirlo-HH-1 (Figure 9) is also acceptable because the most significant diameter nonuniformity is observed only on one end of the specimen $(\mathrm{z}=0 \mathrm{~mm})$ and the remainder of the specimen shows a variation of $<9 \mu \mathrm{m}$. Specimen Zirlo-MH-1 has an oval shape that is constant along its axis. This oval shape was explicitly modeled in the thermal analysis (Section 4.4) and was found to have no significant effect on the part temperatures. Cladding outer diameter measurements for all specimens used in the irradiation experiment can be found in APPENDIX B. 
Table 4. Summary of average cladding dimensional measurements

\begin{tabular}{|c|c|c|c|c|c|c|c|}
\hline $\begin{array}{l}\text { Cladding } \\
\text { Part }\end{array}$ & $\begin{array}{c}\text { Material } \\
\text { (Grade) }\end{array}$ & $\begin{array}{c}\text { Avg } \\
\text { Length } \\
(\mathrm{mm})\end{array}$ & $\begin{array}{c}\text { ID } \\
(\mathbf{m m})\end{array}$ & $\begin{array}{c}\text { Avg } \\
\text { OD } \\
(\mathbf{m m})\end{array}$ & $\begin{array}{l}\text { Max OD } \\
\text { Deviation } \\
(\mathbf{m m})\end{array}$ & $\begin{array}{c}\text { Avg Gas } \\
\text { Gap } \\
(\mathrm{mm})\end{array}$ & $\begin{array}{c}\text { Max OD } \\
\text { Deviation / Avg } \\
\text { Gas Gap (\%) }\end{array}$ \\
\hline C06M-01 & $\mathrm{FeCrAl}(\mathrm{C} 06 \mathrm{M})$ & 15.885 & 8.79 & 9.533 & 0.008 & 0.096 & $8.4 \%$ \\
\hline C06M-02 & $\mathrm{FeCrAl}(\mathrm{C} 06 \mathrm{M})$ & 15.750 & 8.79 & 9.527 & 0.010 & 0.100 & $9.5 \%$ \\
\hline B126Y-1 & $\mathrm{FeCrAl}(\mathrm{B} 126 \mathrm{Y})$ & 23.498 & 8.76 & 9.509 & 0.008 & 0.109 & $7.5 \%$ \\
\hline B126Y-2 & $\mathrm{FeCrAl}(\mathrm{B} 126 \mathrm{Y})$ & 23.481 & 8.76 & 9.509 & 0.005 & 0.109 & $4.5 \%$ \\
\hline B126Y-3 & FeCrAl (B126Y) & 23.305 & 8.76 & 9.510 & 0.004 & 0.108 & $4.1 \%$ \\
\hline B126Y-4 & $\mathrm{FeCrAl}(\mathrm{B} 126 \mathrm{Y})$ & 23.410 & 8.76 & 9.511 & 0.007 & 0.107 & $6.3 \%$ \\
\hline C36M3-1 & $\mathrm{FeCrAl}(\mathrm{C} 36 \mathrm{M} 3)$ & 23.359 & 8.79 & 9.535 & 0.002 & 0.095 & $2.5 \%$ \\
\hline C36M3-2 & $\mathrm{FeCrAl}(\mathrm{C} 36 \mathrm{M} 3)$ & 23.423 & 8.79 & 9.535 & 0.003 & 0.096 & $2.7 \%$ \\
\hline C36M3-3 & $\mathrm{FeCrAl}(\mathrm{C} 36 \mathrm{M} 3)$ & 23.364 & 8.77 & 9.535 & 0.003 & 0.096 & $3.5 \%$ \\
\hline C36M3-4 & $\mathrm{FeCrAl}(\mathrm{C} 36 \mathrm{M} 3)$ & 23.494 & 8.79 & 9.533 & 0.003 & 0.097 & $3.6 \%$ \\
\hline B136Y-1 & $\mathrm{FeCrAl}(\mathrm{B} 136 \mathrm{Y})$ & 23.399 & 8.78 & 9.528 & 0.005 & 0.098 & $5.6 \%$ \\
\hline B136Y-4 & $\mathrm{FeCrAl}(\mathrm{B} 136 \mathrm{Y})$ & 23.356 & 8.79 & 9.526 & 0.005 & 0.100 & $4.9 \%$ \\
\hline Zirlo-1 & ZIRLO & 23.374 & 8.35 & 9.493 & 0.005 & 0.116 & $4.0 \%$ \\
\hline Zirlo-2 & ZIRLO & 23.436 & 8.35 & 9.493 & 0.004 & 0.117 & $3.8 \%$ \\
\hline Zirlo-HH-1 & $\begin{array}{c}\text { ZIRLO (1000 } \\
\text { weight ppm H) }\end{array}$ & 23.476 & 8.35 & 9.508 & 0.021 & 0.096 & $21.7 \%$ \\
\hline Zirlo-MH-1 & $\begin{array}{c}\text { ZIRLO (500 } \\
\text { weight ppm H) }\end{array}$ & 23.476 & 8.37 & 9.511 & 0.014 & 0.095 & $14.7 \%$ \\
\hline Zirc-4H-1 & $\begin{array}{l}\text { Zircaloy-4 (150 } \\
\text { weight ppm H) }\end{array}$ & 23.475 & 8.36 & 9.481 & 0.004 & 0.109 & $3.3 \%$ \\
\hline Zirc-4H-2 & $\begin{array}{l}\text { Zircaloy-4 (150 } \\
\text { weight ppm H) }\end{array}$ & 23.434 & 8.36 & 9.480 & 0.003 & 0.110 & $2.8 \%$ \\
\hline Zirc-4H-3 & $\begin{array}{l}\text { Zircaloy-4 (150 } \\
\text { weight ppm H) }\end{array}$ & 23.437 & 8.36 & 9.481 & 0.003 & 0.110 & $2.5 \%$ \\
\hline ZIRLO-H-3 & $\begin{array}{c}\text { ZIRLO (250 } \\
\text { weight ppm H) }\end{array}$ & 23.511 & 8.35 & 9.505 & 0.004 & 0.098 & $3.9 \%$ \\
\hline ZIRLO-H-4 & $\begin{array}{c}\text { ZIRLO }(250 \\
\text { weight ppm H) }\end{array}$ & 23.347 & 8.35 & 9.505 & 0.008 & 0.097 & $8.7 \%$ \\
\hline ZIRLO-H-5 & $\begin{array}{c}\text { ZIRLO }(250 \\
\text { weight ppm H) }\end{array}$ & 23.441 & 8.35 & 9.504 & 0.002 & 0.098 & $2.5 \%$ \\
\hline
\end{tabular}



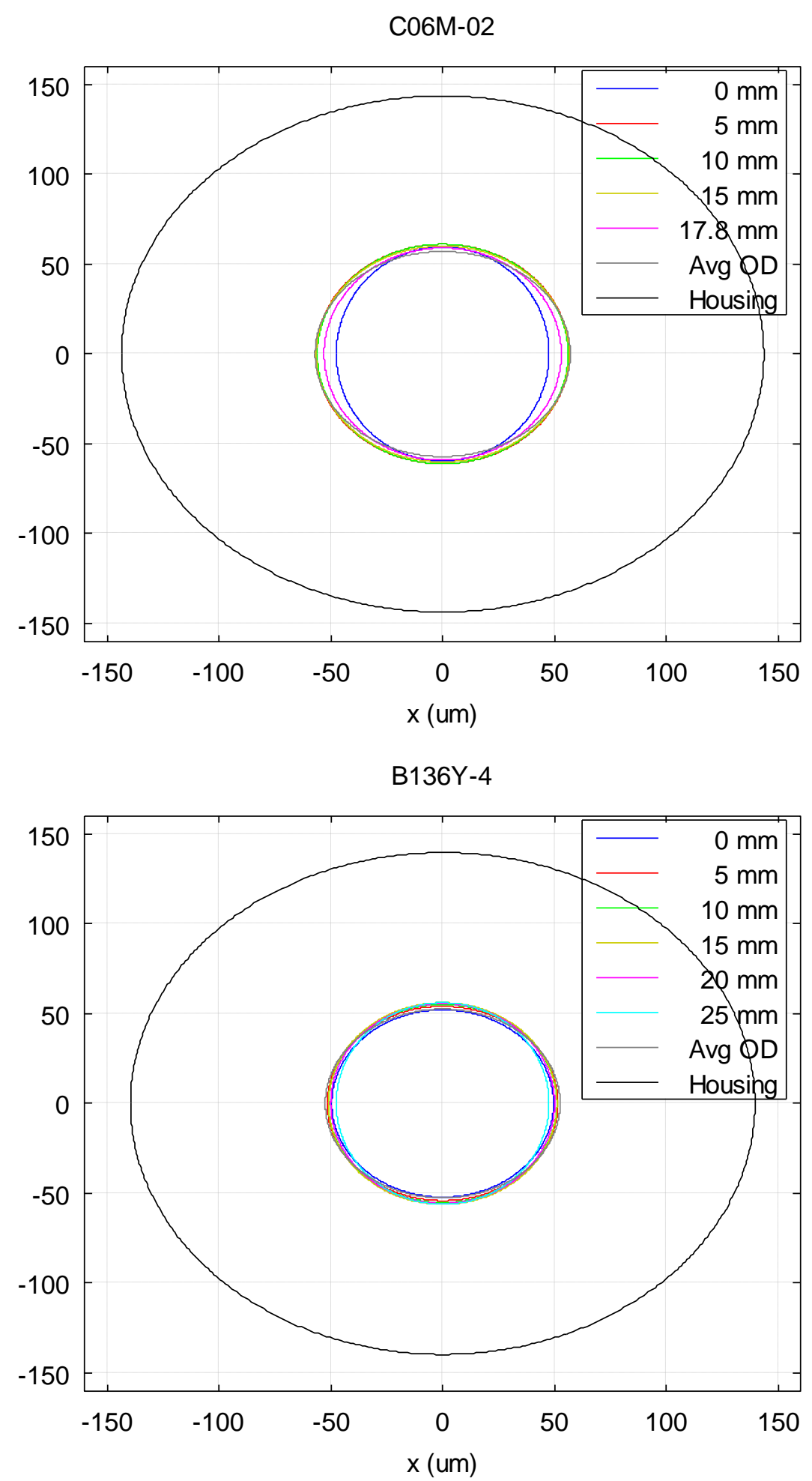

Figure 8. Cladding outer diameter measurements for two FeCrAl specimens compared to the nominal $9.70 \mathrm{~mm}$ housing inner diameter. All $x$ and $y$ values are scaled such that they are $x$ and $y$ distances from some arbitrary reference radius that is unique to each specimen. 


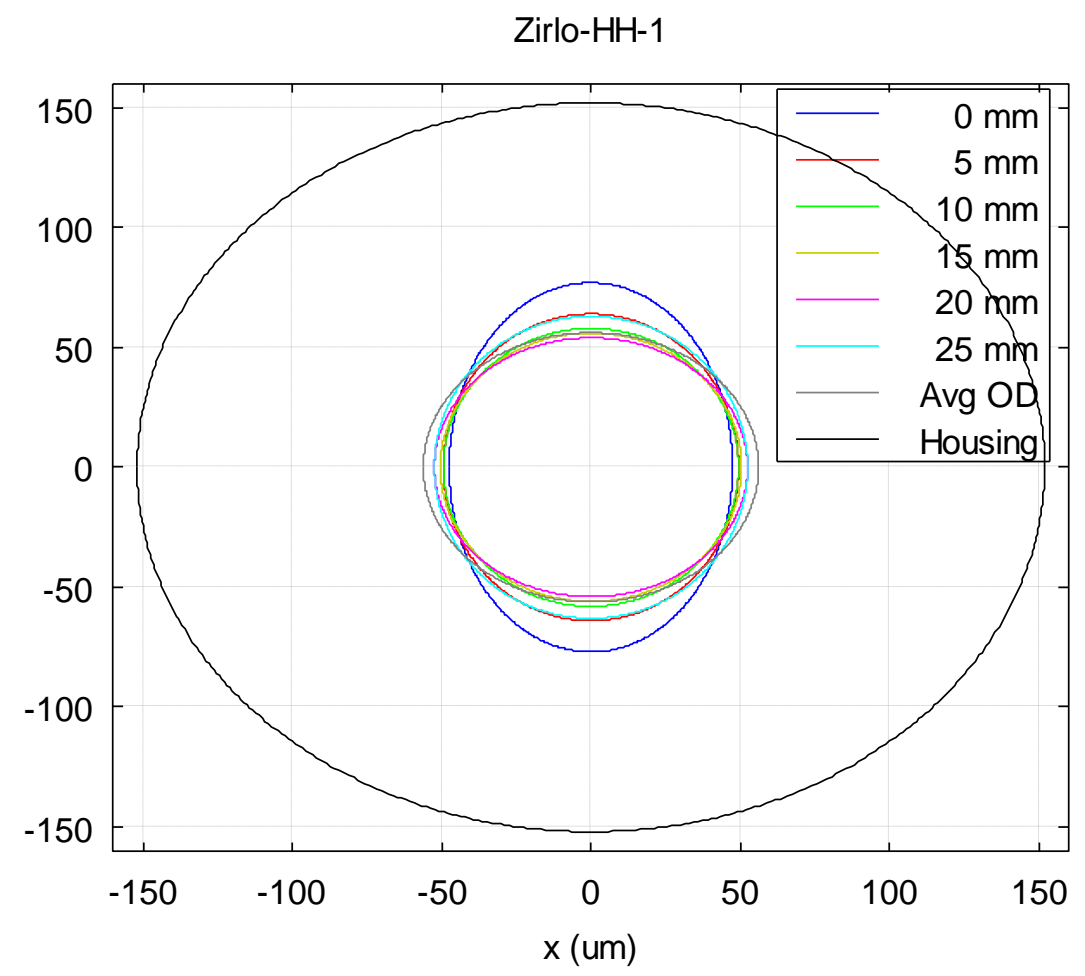

Zirlo-MH-1

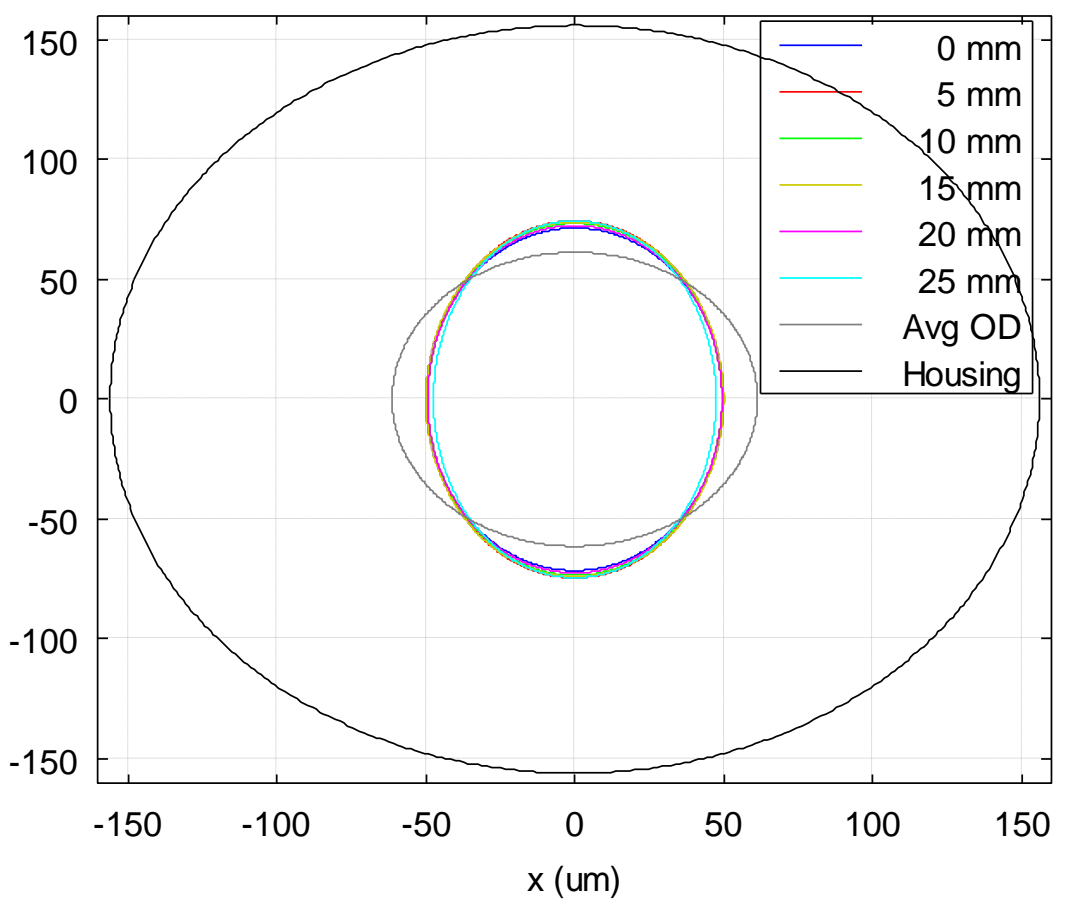

Figure 9. Cladding outer diameter measurements for two $\mathrm{Zr}$-alloy specimens compared to the nominal $9.70 \mathrm{~mm}$ housing inner diameter. All $x$ and $y$ values are scaled such that they are $x$ and $y$ distances from some arbitrary reference radius that is unique to each specimen. 
The inner diameters of the housings were inspected in a similar manner. Table 5 summarizes average dimensional measurements for all housings. The ratio of housing inner diameter deviation to gas gap assumes a nominal gas gap of $0.100 \mathrm{~mm}$ for all cases. The exact gas gap will depend on the specific pairing of housing and cladding. Section 4.4 shows that this nominal gap is typical for the cladding/housing pairing that was selected. Figure 10 shows one example of housing inner diameter measurements at five axial locations. Similar to the data for the cladding specimens in Figure 8 and Figure 9, the $x$ and $y$ values in Figure 10 are scaled such that they are $x$ and $y$ distances from some arbitrary reference radius that is unique to each housing. This allows one to observe the variations in the housing inner diameter at various axial locations $(z)$ compared to the nominal cladding outer diameter of $9.50 \mathrm{~mm}$. Both the housing inner diameter values and the nominal cladding outer diameter are scaled to the same reference radius. Figure 10 shows that housing 16-12 has an inner diameter that is constant to within $\pm 5 \mu \mathrm{m}$ along the entire length of the part. Housing inner diameter measurements for all parts can be found in APPENDIX B.

Table 5. Summary of average housing dimensional measurements.

\begin{tabular}{|c|c|c|c|}
\hline Part \# & $\begin{array}{c}\text { Avg ID } \\
(\mathbf{m m})\end{array}$ & $\begin{array}{c}\text { ID Max } \\
\text { Deviation (mm) }\end{array}$ & $\begin{array}{c}\text { ID Max Deviation / } \\
\text { Nominal Gas gap }\end{array}$ \\
\hline $16-01$ & 9.725 & 0.005 & $5.1 \%$ \\
\hline $16-02$ & 9.733 & 0.007 & $6.7 \%$ \\
\hline $16-03$ & 9.726 & 0.004 & $4.3 \%$ \\
\hline $16-04$ & 9.722 & 0.003 & $3.3 \%$ \\
\hline $16-05$ & 9.730 & 0.002 & $1.7 \%$ \\
\hline $16-06$ & 9.726 & 0.003 & $3.2 \%$ \\
\hline $16-07$ & 9.727 & 0.006 & $5.5 \%$ \\
\hline $16-08$ & 9.726 & 0.006 & $5.6 \%$ \\
\hline $16-09$ & 9.724 & 0.003 & $3.1 \%$ \\
\hline $16-10$ & 9.726 & 0.004 & $4.4 \%$ \\
\hline $16-11$ & 9.719 & 0.002 & $2.0 \%$ \\
\hline $16-12$ & 9.727 & 0.005 & $4.6 \%$ \\
\hline $16-13$ & 9.720 & 0.004 & $4.4 \%$ \\
\hline $16-14$ & 9.722 & 0.004 & $3.6 \%$ \\
\hline $16-15$ & 9.723 & 0.003 & $3.3 \%$ \\
\hline $16-16$ & 9.724 & 0.003 & $2.9 \%$ \\
\hline $16-17$ & 9.724 & 0.004 & $4.0 \%$ \\
\hline $16-18$ & 9.724 & 0.003 & $3.2 \%$ \\
\hline Note: Avg $=$ Average, Max $=$ Maximum, ID = Inner Diameter \\
\hline
\end{tabular}


Housing 16-12

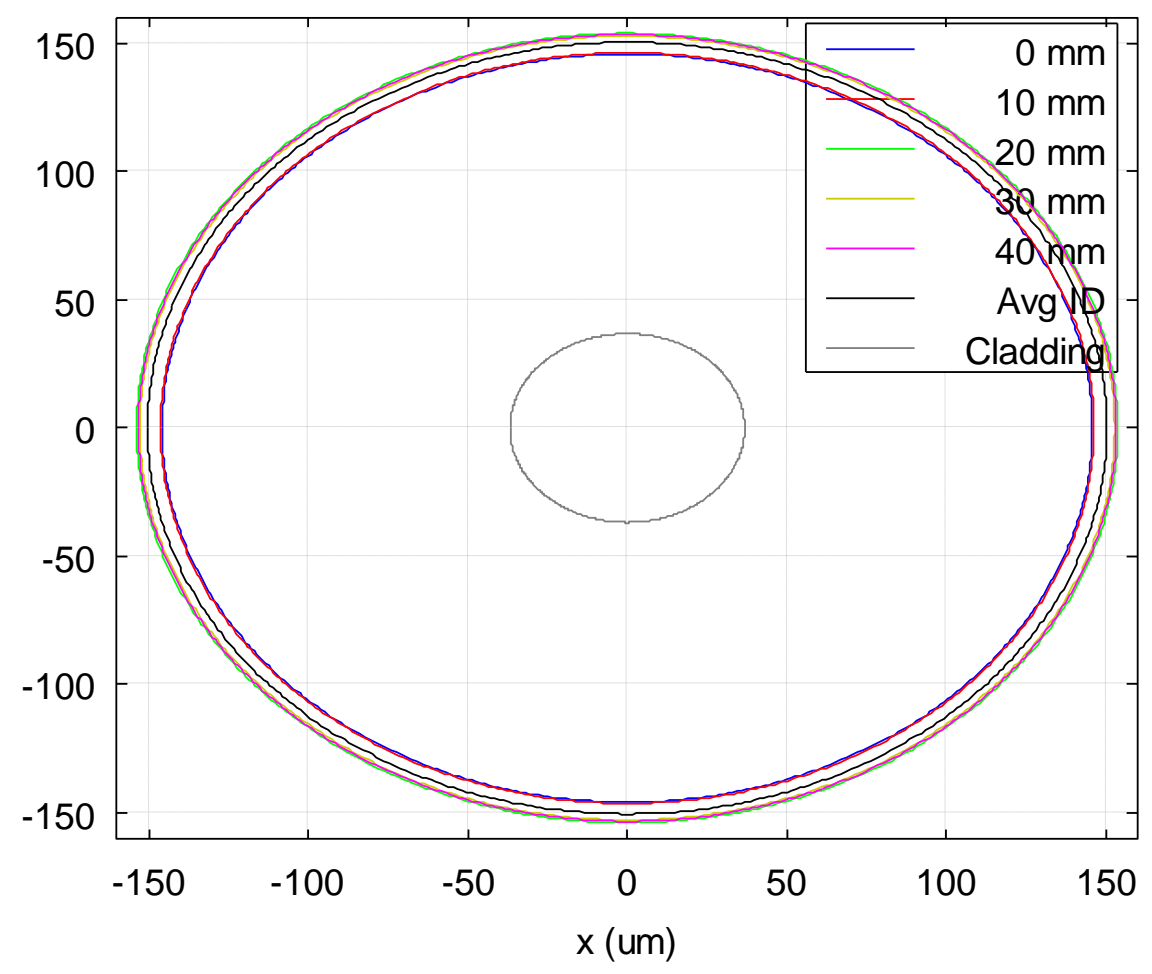

Figure 10. Measurements of one housing inner diameter at various axial locations as well as the nominal housing inner diameter. All $x$ and $y$ values are scaled such that they are $x$ and $y$ distances from some arbitrary reference radius that is unique to each specimen.

\subsection{FLOW TESTING}

\subsubsection{Test Results}

Flow tests were performed to determine flow through a PTP holder for two cases: (1) a PTP holder loaded with seven standard size rabbits and (2) a PTP holder loaded with seven large-bore rabbits. Table 6 shows the time-averaged values with errors for the flow rate $(Q)$ and pressure drop $(P)$ for each step in flow rate. This data is plotted in Figure 11 along with a curve fit using the bulk loss coefficient described later in this section. Measurement errors are quantified by calculating the standard deviation of the data for each interval of interest. In addition to the measurement variability, there are errors due to (1) elevation differences between the pressure transducers and the test section and (2) calibration error in the instrumentation. The error due to pressure transducer elevation effects was quantified in an earlier calculation to be $0.69 \mathrm{kPa}(0.10 \mathrm{psid})$ [35]. As described earlier in Section 2.2.1, the calibration errors in the pressure transducers and flow meter are $0.55 \mathrm{kPa}(0.08 \mathrm{psid})$ and $2.78 \mathrm{cc} / \mathrm{s}(0.044 \mathrm{gpm})$ for the differential pressure gage and flow meter, respectively. These elevation and calibration errors are of similar magnitude compared to the measurement variability. Note that the uncertainty and errors are only a few percent of the measured values. 
Table 6. Averaged flow and pressure drop data for the two tests that were performed

\begin{tabular}{|c|c|c|c|}
\hline \multicolumn{2}{|c|}{ Case 1 (seven standard rabbits) } & \multicolumn{2}{c|}{ Case 2 (seven large-bore rabbits) } \\
\hline Flow rate, $\boldsymbol{Q}(\mathbf{c c} / \mathbf{s})$ & Pressure drop, $\boldsymbol{P}(\mathbf{k P a})$ & Flow rate, $\boldsymbol{Q}(\mathbf{c c} / \mathbf{s})$ & Pressure drop, $\boldsymbol{P}(\mathbf{k P a})$ \\
\hline $228.7 \pm 4.2$ & $67.0 \pm 1.1$ & $218.8 \pm 4.0$ & $68.1 \pm 1.3$ \\
\hline $333.1 \pm 4.7$ & $136.2 \pm 3.1$ & $312.6 \pm 3.9$ & $135.0 \pm 3.1$ \\
\hline $408.3 \pm 3.9$ & $199.1 \pm 3.0$ & $391.5 \pm 3.4$ & $202.4 \pm 3.7$ \\
\hline $470.0 \pm 2.9$ & $262.2 \pm 4.2$ & $462.5 \pm 2.8$ & $279.0 \pm 4.8$ \\
\hline $542.9 \pm 2.4$ & $344.5 \pm 5.5$ & $517.9 \pm 2.6$ & $347.7 \pm 6.2$ \\
\hline $605.2 \pm 2.6$ & $427.3 \pm 5.9$ & $578.5 \pm 2.6$ & $430.8 \pm 6.5$ \\
\hline
\end{tabular}

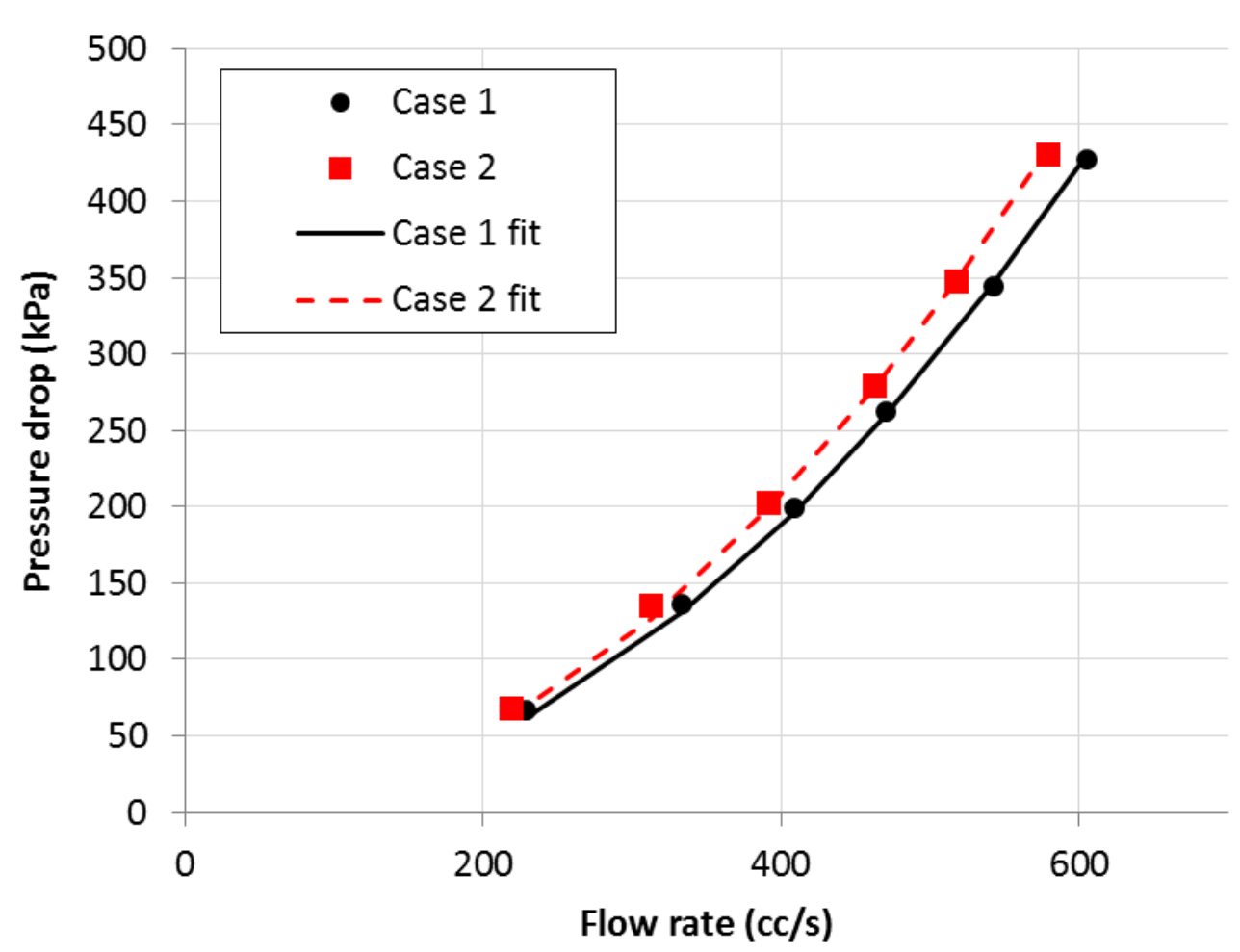

Figure 11. Pressure drop vs. flow rate data with curve fits.

The bounding limit for flow in a PTP holder is $246 \mathrm{cc} / \mathrm{s}$ (3.9 gpm) [36]. This amount of flow must be achieved when the pressure drop across the flux trap bundle (which is essentially equivalent to the pressure drop measured in the experiments described in this document) is as low as $228 \mathrm{kPa}$ (33 psig) [32, 37]. Table 6 shows that for a PTP holder loaded with seven large-bore rabbits (Case 2) a flow rate of $312.6 \mathrm{cc} / \mathrm{s}(4.95 \mathrm{gpm})$, which is greater than the $246 \mathrm{cc} / \mathrm{s}$ requirement, can be achieved with a much lower pressure drop of $135.0 \mathrm{kPa}(19.6 \mathrm{psig})$. Interpolation between the tabulated data gives a flow rate of $415 \mathrm{cc} / \mathrm{s}(6.6 \mathrm{gpm})$ at a pressure drop of $228 \mathrm{kPa}$ (33 psig). Therefore, the large-bore rabbits do not have any issues with flow restriction in a PTP holder.

Additional efforts were made to determine a bulk loss coefficient for these rabbits. The functional form for the pressure drop is

$$
P=\mathrm{k} \times \frac{\rho}{2} \times\left(\frac{Q}{A}\right)^{2}
$$


where $k$ is the bulk loss coefficient for the test section (unitless), $\rho$ is the fluid density $\left(997.7 \mathrm{~kg} / \mathrm{m}^{3}\right.$ at $22^{\circ} \mathrm{C}$ [38]), and $A$ is the channel flow area $\left(\mathrm{m}^{2}\right)$. The flow channel is an annulus with four tabs in the PTP holder that keep the rabbits centered in the channel. The Creo CAD software package is used to calculate flow areas and hydraulic diameters (calculated as four times the flow area divided by the wetted perimeter) for both cases. These parameters are summarized in Table 7.

Table 7. Flow areas and hydraulic diameters for the two experiment cases

\begin{tabular}{|c|c|c|}
\hline Case & Flow area $\left(\mathbf{m m}^{\mathbf{2}}\right)$ & Hydraulic Diameter $(\mathbf{m m})$ \\
\hline Case 1 (7 standard rabbits) & 68.99 & 3.40 \\
\hline Case 2 (7 large bore rabbits) & 64.11 & 3.12 \\
\hline
\end{tabular}

The single unknown in the expression for pressure drop is the bulk loss term, $\mathrm{k}$. The dynamic pressure term (i.e., $\frac{\rho}{2} \times\left(\frac{Q}{A}\right)^{2}$ ) is calculated for all flow rates and all cases using the fluid density and flow areas described above. Table 8 shows the calculated dynamic pressure and the measured pressure drop for all measured flow rates and both test cases. Ignoring uncertainty in the fluid density and the channel flow area, uncertainties in the dynamic pressures (as a percent) are equal to twice those of the flow rates listed in Table 6 due to the dependence of dynamic pressure on the square of the flow rate. Figure 12 shows pressure drop vs. dynamic pressure for Cases 1 and 2, along with linear least-squares fits that determine the scaled bulk loss coefficient $k$. The loss coefficients (i.e., $k$ ) for Cases 1 and 2 are calculated to be 11.22 and 10.71, respectively. This means that for a given dynamic pressure, the system pressure drop is higher for Case 1 compared to Case 2.

Table 8. Dynamic pressure and pressure drop (loss pressure) for the two experiment cases

\begin{tabular}{|c|c|c|c|}
\hline \multicolumn{2}{|c|}{ Case 1 (seven standard rabbits) } & \multicolumn{2}{c|}{ Case 2 (seven large-bore rabbits) } \\
\hline Dynamic pressure (kPa) & Pressure drop (kPa) & Dynamic pressure (kPa) & Pressure drop (kPa) \\
\hline 5.5 & 67.0 & 5.8 & 68.1 \\
\hline 11.6 & 136.2 & 11.9 & 135.0 \\
\hline 17.5 & 199.1 & 18.6 & 202.4 \\
\hline 23.2 & 262.2 & 26.0 & 279.0 \\
\hline 30.9 & 344.5 & 32.6 & 347.7 \\
\hline 38.4 & 427.3 & 40.6 & 430.8 \\
\hline
\end{tabular}




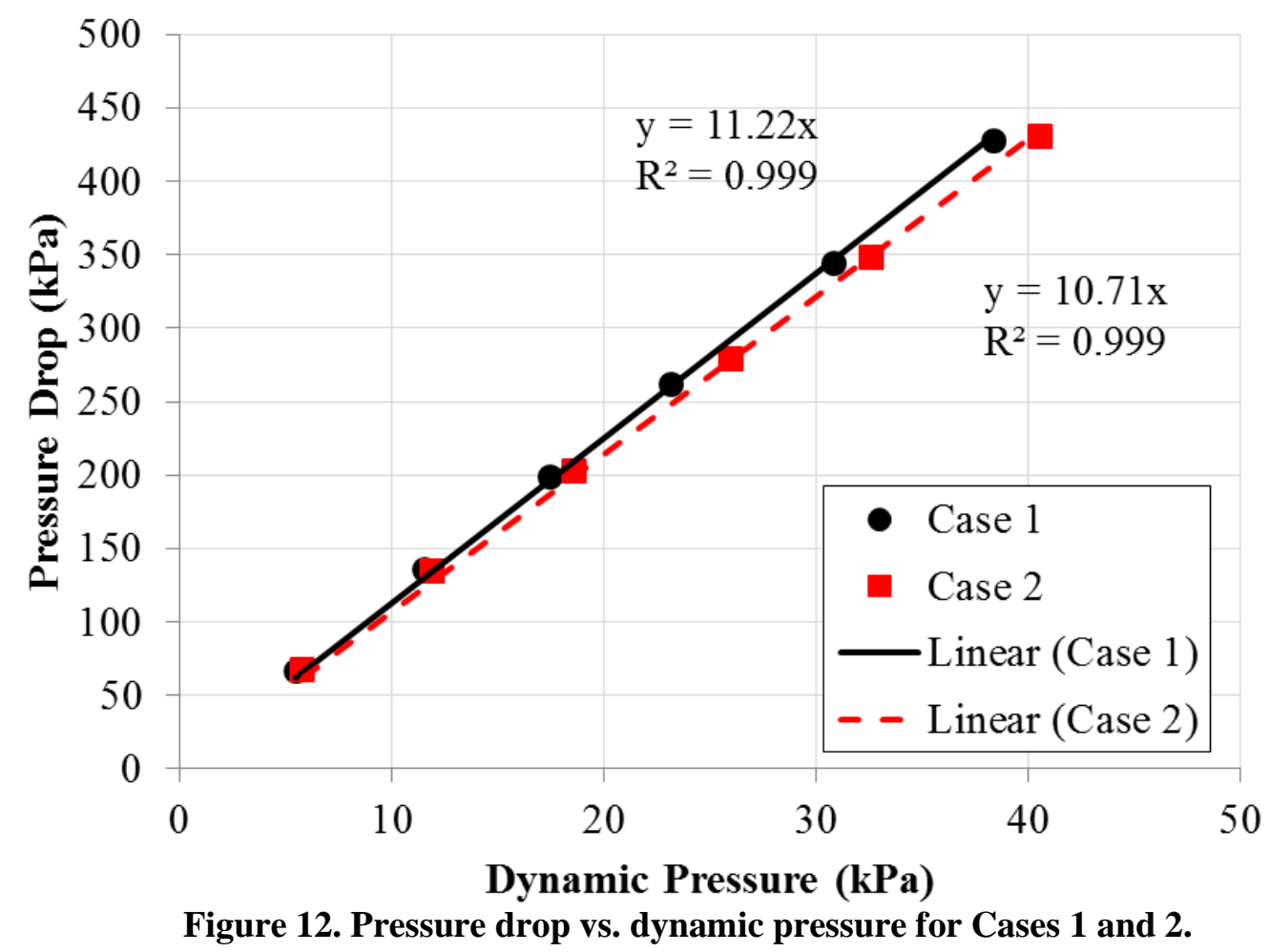

\subsubsection{Convective Heat Transfer Coefficients}

The results from this flow experiment and analysis show that large-bore rabbit capsules have a slight reduction in flow rate inside a PTP holder, when compared to standard rabbit capsules in a PTP holder. However, the benchmark flow characteristics for the standard rabbit case, as detailed in C-HFIR-2001026 , are $231.91 \mathrm{cc} / \mathrm{s}$ (3.66 gpm) at $228 \mathrm{kPa}$ (33 psid) [36]. It is clear that the improved flow test data from the present experiment show flow that greatly outperforms the benchmark data. At $228 \mathrm{kPa}$ (33 psid) Case 1 yields $437 \mathrm{cc} / \mathrm{s}$ (6.9 gpm) and Case 2 yields $415 \mathrm{cc} / \mathrm{s}(6.6 \mathrm{gpm})$.

While this improvement in flow satisfies concerns regarding flow restrictions with the large-bore rabbits, there is some concern that the significantly increased flow could affect the thermal analyses that were performed using convective heat transfer coefficients that assumed benchmark flow data. The average convective heat transfer coefficient for the PTP facility was calculated to be $48.4 \mathrm{~kW} / \mathrm{m}^{2}-\mathrm{K}$ with a volumetric flow rate of $306 \mathrm{cc} / \mathrm{s}$ [32]. This is the value that is used later in the thermal analyses described in Section 4.4. This value was determined using a Nusselt number calculated using the following correlation:

$$
N u=0.027 \operatorname{Re}^{0.8} \operatorname{Pr}^{1 / 3}\left(\frac{\mu_{b}}{\mu_{w}}\right)^{0.14},
$$

where $N u$ is the Nusselt number, $R e$ the Reynolds number, $\operatorname{Pr}$ the Prandtl number, $\mu_{b}$ the bulk liquid viscosity, and $\mu_{w}$ the wall liquid viscosity. For the large-bore rabbit case (LB), the average Reynolds number $\left(R e_{L B}\right)$ can be scaled from the reference (ref) value $\left(R e_{r e f}\right)$ using the volumetric flow rates $\left(Q_{l b}\right.$ and $\left.Q_{r e f}\right)$, hydraulic diameters $\left(D_{l b}\right.$ and $\left.D_{r e f}\right)$, and flow areas $\left(A_{l b}\right.$ and $\left.A_{r e f}\right)$. This way, the calculated value for $R e_{L B}$ is 


$$
R e_{L B}=\frac{\frac{Q_{l b} D_{l b}}{A_{l b}}}{\frac{Q_{r e f} D_{r e f}}{A_{\text {ref }}}} \operatorname{Re} e_{r e f}=\frac{\frac{\left[415 \mathrm{~cm}^{3} / \mathrm{s}\right]\left[3.12 \times 10^{-3} \mathrm{~m}\right]}{\left[6.41 \times 10^{-5} \mathrm{~m}^{2}\right]}}{\frac{\left[306 \mathrm{~cm}^{3} / \mathrm{s}\right]\left[2.15 \times 10^{-3} \mathrm{~m}\right]}{\left[4.06 \times 10^{-5} \mathrm{~m}^{2}\right]}}[30,865]=38,475
$$

Note that there is a significant difference in the flow areas and hydraulic diameters for the large-bore case compared to the reference case. The primary reason for this difference is that the large-bore rabbits were tested with the latest PTP holder design with centering tabs. The new PTP holder results in significantly larger flow areas and hydraulic diameters. The average Nusselt number for the large-bore case $\left(N u_{L B}\right)$ can be calculated from the average Nusselt number for the reference case $\left(N u_{r e f}\right)$ scaled by the ratio of Reynolds number to the 0.8 power. $N u_{L B}$ is calculated to be

$$
N u_{L B}=\frac{R e_{L B}^{0.8}}{R e_{r e f}^{0.8}} N u_{r e f}=\frac{[38,475]^{0.8}}{[30,865]^{0.8}}[160]=191 .
$$

Finally, the convective heat transfer coefficient for the large-bore case $\left(D_{l b}\right)$ is calculated using $N u_{L B}$, $D_{l b}$, and the average thermal conductivity of the coolant $\left(k_{\text {coolant }}\right)$ to be

$$
h_{L B}=\frac{N u_{L B} k_{\text {coolant }}}{D_{l b}}=\frac{[191]\left[0.65 \frac{\mathrm{W}}{\mathrm{m} \mathrm{K}}\right]}{\left[3.12 \times 10^{-3} \mathrm{~m}\right]}=39,792 \frac{\mathrm{W}}{\mathrm{m}^{2} \mathrm{~K}} .
$$

These calculations show that the large-bore convective heat transfer coefficient is roughly $18 \%$ lower than the reference case. However, this will not significantly affect capsule component temperatures as the temperature drop from the housing outer surface to the bulk coolant is $\sim 2^{\circ} \mathrm{C}$. Changing this temperature drop by $18 \%$ will result in less than a $0.4^{\circ} \mathrm{C}$ difference in component temperatures.

\subsection{NEUTRONICS ANALYSIS}

Table 9 summarizes the total peak heat generation rates for the aluminum housing, molybdenum sleeve, FeCrAl cladding, and Zircaloy-4 cladding during irradiation in PTP and TRRH positions. Results are shown at BOC and EOC, as well as the average of BOC and EOC values. Variations from BOC to EOC are relatively small (in the range of 3-6\%). These variations are primarily due to the region within the HFIR fuel with the highest fission density moving radially outward toward the EOC. As a result, gammas born during the fission process experience increased attenuation as they must travel a longer distance before reaching the experiment materials. PTP heat generation rates are higher than those in TRRH positions because of the closer proximity of PTP positions to the fuel. As expected, heat generation rates increase with atomic number due to increased gamma absorption. Increased gamma absorption in the Zircaloy-4 cladding also explains why molybdenum (located inside the cladding) heat generation rates are lower for Zircaloy-4 cladding compared to FeCrAl cladding. 
Table 9. Heat generation rates (W/g) for various materials at BOC and EOC in PTP and TRRH centerline positions

\begin{tabular}{|c|c|c|c|c|c|c|c|}
\cline { 3 - 8 } \multicolumn{2}{c|}{} & \multicolumn{2}{c|}{ BOC } & \multicolumn{2}{c|}{ EOC } & \multicolumn{2}{c|}{ Average } \\
\hline $\begin{array}{c}\text { Cladding } \\
\text { Material }\end{array}$ & Component & PTP & TRRH & PTP & TRRH & PTP & TRRH \\
\hline FeCrAl & Aluminum housing & 30.7 & 29.6 & 29.3 & 28.3 & 30.1 & 29.0 \\
\hline & Molybdenum sleeve & 44.3 & 43.3 & 42.9 & 41.6 & 43.6 & 42.5 \\
\hline & FeCrAl cladding & 35.2 & 34.4 & 33.6 & 32.6 & 34.4 & 33.5 \\
\hline Zircaloy-4 & Aluminum housing & 30.0 & 29.0 & 28.5 & 27.7 & 29.3 & 28.3 \\
\hline & Molybdenum sleeve & 41.7 & 40.5 & 40.2 & 39.1 & 41.0 & 39.8 \\
\hline & Zircaloy-4 cladding & 47.4 & 46.2 & 44.8 & 44.0 & 46.1 & 45.1 \\
\hline
\end{tabular}

Table 10 summarizes the percentage contributions from the various source of heat generation. Results are shown for aluminum, molybdenum, FeCrAl, and Zircaloy-4 in a PTP position at BOC and EOC.

Aluminum and molybdenum results are shown only for the case with a FeCrAl cladding. Percentages do not change significantly with varying position or cladding material. Clearly, prompt photons and fission product decay photons are the dominant sources of heat generation in these materials. Neutron heating decreases with increasing atomic number. Therefore, neutron heating is most significant in aluminum (the material with the lowest atomic number); however, even for aluminum, this contribution is less than $4 \%$ of the total heat generation rate. Local decay heat is mostly negligible except for aluminum, which has a somewhat significant contribution from local decay heat due to the rapid beta decay of aluminum-28, which is produced from the $(\mathrm{n}, \mathrm{g})$ reaction in aluminum- 27 .

Table 10. Contributions to heat generation rates in experiment materials from various sources at BOC and EOC in PTP positions

\begin{tabular}{|l|c|c|c|c|c|c|c|c|}
\hline \multirow{2}{*}{ Material } & \multicolumn{2}{|l|}{ Fission Neutrons } & \multicolumn{2}{|c|}{ Fission Photons } & \multicolumn{2}{|c|}{$\begin{array}{c}\text { Fission Product } \\
\text { Photons }\end{array}$} & \multicolumn{2}{c|}{$\begin{array}{c}\text { Local Decay } \\
\text { Heating }\end{array}$} \\
\cline { 2 - 9 } & BOC & EOC & BOC & EOC & BOC & EOC & BOC & EOC \\
\hline Al6061 & $3.3 \%$ & $3.0 \%$ & $66.3 \%$ & $66.6 \%$ & $27.2 \%$ & $26.6 \%$ & $3.3 \%$ & $3.8 \%$ \\
\hline FeCrAl & $3.0 \%$ & $3.1 \%$ & $67.9 \%$ & $68.3 \%$ & $28.9 \%$ & $28.3 \%$ & $0.3 \%$ & $0.3 \%$ \\
\hline Molybdenum & $0.1 \%$ & $0.1 \%$ & $68.9 \%$ & $68.8 \%$ & $30.8 \%$ & $30.7 \%$ & $0.2 \%$ & $0.5 \%$ \\
\hline Zirc4 & $0.7 \%$ & $0.6 \%$ & $66.3 \%$ & $66.5 \%$ & $33.0 \%$ & $32.9 \%$ & $0.0 \%$ & $0.0 \%$ \\
\hline
\end{tabular}

\subsection{THERMAL ANALYSIS}

\subsubsection{Test Matrix and Evaluation Cases}

Thermal analyses were performed for each rabbit that is to be irradiated. These analyses determine temperature distributions within the experiment using as-built housing and specimen dimensions and the desired fill gas (i.e., the specific helium/argon mixture). The cladding specimens were modeled as ovals with major and minor diameters equal to the average major and minor diameters, respectively, over the entire length of the part. In this way, the ovality of the specimens is considered but variations in the ovality are not. However, as summarized in Section 4.1, the specimens generally showed little diameter 
variations along the length except for a few specimens that showed significant variations that were limited to one end of the specimen. The housings were modeled as plain cylinders because the dimensional measurements did not show any significant variations in the housing inner diameter.

Table 11 summarizes the irradiation test matrix, cladding specimen, housing, and sleeve pairing, gas gaps (using average cladding and housing dimensions), and gas mixtures for each rabbit. Cladding specimens were paired with specific housings so that rabbits could be grouped together with others that have a similar gas gap (and thus a similar gas mixture, assuming the heat flux through the cladding-to-housing gas gap is approximately the same). Each rabbit can accommodate two cladding specimens, so efforts were made to pair specimens with similar outer diameters. However, in order to irradiate a wide variety of materials to varying dose levels, two different specimen material grades (with slightly different geometry) were often loaded into a single rabbit to reduce the total number of rabbits (for cost reasons). Because the different specimen material grades produced slightly different outer diameters, it was sometimes impossible to achieve the same gas gap for both specimens within each rabbit.

Previous irradiations of $\mathrm{Zr}$-alloy cladding with molybdenum on the inside resulted in the molybdenum parts getting stuck inside the cladding [39]. In this work, the molybdenum sleeves were machined such that the gap between the sleeve and the cladding was large enough that it would not close due to sleeve swelling and cladding shrinkage (for the case of Zr-alloy cladding specimens). Zr-alloys are known to grow in the axial ( $<\mathrm{a}\rangle$ axis) direction during irradiation in a constant-volume process, resulting in a concomitant shrinkage in the radial direction with a magnitude that is approximately half of the $\langle a>$ axis growth. The observed growth rate in the $\langle\mathrm{a}>$ axis for both an as-extruded $\mathrm{Zr}$-alloy and a cold-worked Zircaloy-2 tube during neutron irradiation was $0.06 \%$ per dpa [40]. Growth rates for annealed Zircaloy-2 and cold-worked Zircaloy-2 in other geometries were much less and in some cases were as low as $0.012 \%$ per dpa. Growth rates for the $\mathrm{Zr}$-alloy tubes that are to be irradiated in this experiment are conservatively assumed to be $0.06 \%$ per dpa. The maximum dose to which the specimens will be exposed is $26 \mathrm{dpa}$, which results in an $<\mathrm{a}>$ axis growth strain of $1.6 \%$, or a radial shrinkage of $\sim 0.8 \%$.

Radiation-induced dimensional changes in FeCrAl (a ferritic alloy) are expected to be negligible [41, 42], with the possibility of very minor swelling, which would increase the sleeve-to-cladding gap. Volumetric radiation swelling of molybdenum was assumed to be at most $2 \%$ ( $0.67 \%$ linear swelling), which is the maximum observed swelling for low-carbon arc cast molybdenum in the literature [43]. For $\mathrm{Zr}$-alloy cladding with a maximum inner diameter of $8.79 \mathrm{~mm}$ (4.40 mm inner radius), gap closure due to both Zr-alloy radial shrinkage and molybdenum swelling would be at most $4.40 \mathrm{~mm} \times(0.8 \%+0.67 \%)=$ $0.065 \mathrm{~mm}$. This calculation is also conservative because it assumes that the molybdenum sleeve outer diameter is equal to the cladding inner diameter. For $\mathrm{FeCrAl}$ cladding with a maximum cladding inner diameter of $8.37 \mathrm{~mm}$ ( $4.19 \mathrm{~mm}$ inner radius), gap closure due to molybdenum swelling would be at most $4.19 \mathrm{~mm} \times 0.67 \%=0.028 \mathrm{~mm}$. Table 11 shows that all sleeve-to-cladding gaps are greater than $0.065 \mathrm{~mm}$ and $0.028 \mathrm{~mm}$ for $\mathrm{Zr}$-alloy and $\mathrm{FeCrAl}$ cladding, respectively. 
Table 11. Irradiation test matrix, cladding specimen, housing, and sleeve pairing, gas gaps (using average cladding and housing dimensions), and gas mixtures for each rabbit

\begin{tabular}{|c|c|c|c|c|c|c|c|c|c|c|c|}
\hline Case & Loc & $\begin{array}{l}\text { Hous } \\
\text { Part \# }\end{array}$ & $\begin{array}{l}\text { Specimen } \\
\text { Part \# }\end{array}$ & $\begin{array}{c}\text { Avg } \\
\text { hous } \\
\text { ID } \\
(\mathbf{m m})\end{array}$ & $\begin{array}{c}\text { Clad } \\
\text { ID } \\
(\mathbf{m m})\end{array}$ & $\begin{array}{c}\text { Avg } \\
\text { clad } \\
\text { minor } \\
\text { OD } \\
(\mathbf{m m})\end{array}$ & $\begin{array}{c}\text { Avg } \\
\text { clad } \\
\text { major } \\
\text { OD } \\
(\mathbf{m m})\end{array}$ & $\begin{array}{c}\text { Sleeve } \\
\text { OD } \\
(\mathbf{m m})\end{array}$ & $\begin{array}{c}\text { Avg } \\
\text { clad- } \\
\text { to- } \\
\text { hous } \\
\text { gap } \\
(\mathrm{mm})\end{array}$ & $\begin{array}{c}\text { Sleeve- } \\
\text { to-clad } \\
\text { gap } \\
(\mathbf{m m})\end{array}$ & $\begin{array}{c}\text { Fill gas } \\
\text { He } \\
\text { fraction }\end{array}$ \\
\hline \multirow{2}{*}{ FCF01 } & \multirow{2}{*}{ TRRH-3 } & \multirow{2}{*}{$16-16$} & C06M-01 & \multirow{2}{*}{9.724} & 8.79 & 9.528 & 9.538 & 8.69 & 0.095 & 0.050 & \multirow{2}{*}{0.92} \\
\hline & & & B136Y-1 & & 8.78 & 9.524 & 9.532 & 8.67 & 0.098 & 0.055 & \\
\hline \multirow{2}{*}{ FCF02 } & \multirow{2}{*}{ TRRH-5 } & \multirow{2}{*}{$16-06$} & C06M-02 & \multirow{2}{*}{9.726} & 8.79 & 9.521 & 9.533 & 8.69 & 0.099 & 0.050 & \multirow{2}{*}{0.97} \\
\hline & & & B136Y-4 & & 8.79 & 9.521 & 9.531 & 8.71 & 0.100 & 0.040 & \\
\hline \multirow{2}{*}{ FCF03 } & \multirow{2}{*}{ TRRH-3 } & \multirow{2}{*}{$16-07$} & B126Y-1 & \multirow{2}{*}{9.727} & 8.76 & 9.498 & 9.520 & 8.65 & 0.109 & 0.055 & \multirow{2}{*}{0.97} \\
\hline & & & C36M3-4 & & 8.79 & 9.530 & 9.536 & 8.70 & 0.097 & 0.045 & \\
\hline \multirow{2}{*}{ FCF04 } & \multirow{2}{*}{ TRRH-5 } & \multirow{2}{*}{$16-12$} & B126Y-2 & \multirow{2}{*}{9.727} & 8.76 & 9.503 & 9.515 & 8.66 & 0.109 & 0.050 & \multirow{2}{*}{0.97} \\
\hline & & & C36M3-2 & & 8.79 & 9.531 & 9.539 & 8.71 & 0.096 & 0.040 & \\
\hline \multirow{2}{*}{ FCF05 } & \multirow{2}{*}{ TRRH-5 } & \multirow{2}{*}{$16-03$} & B126Y-3 & \multirow{2}{*}{9.726} & 8.76 & 9.503 & 9.517 & 8.66 & 0.108 & 0.050 & \multirow{2}{*}{0.97} \\
\hline & & & C36M3-3 & & 8.77 & 9.531 & 9.539 & 8.66 & 0.096 & 0.055 & \\
\hline \multirow{2}{*}{ FCF06 } & \multirow{2}{*}{ TRRH-5 } & \multirow{2}{*}{$16-01$} & B126Y-4 & \multirow{2}{*}{9.725} & 8.76 & 9.501 & 9.520 & 8.66 & 0.107 & 0.050 & \multirow{2}{*}{0.97} \\
\hline & & & C36M3-1 & & 8.79 & 9.531 & 9.539 & 8.71 & 0.095 & 0.040 & \\
\hline \multirow{2}{*}{ FCZ01 } & \multirow{2}{*}{ TRRH-3 } & $16-17$ & Zirlo-1 & & 8.35 & 9.490 & 9.496 & 8.20 & 0.116 & 0.075 & 1 \\
\hline & & $10-1 /$ & ZIRLO-MH-1 & .124 & 8.37 & 9.487 & 9.535 & 8.21 & 0.107 & 0.080 & 1 \\
\hline 702 & & & Zirlo-2 & & 8.35 & 9.490 & 9.496 & 8.21 & 0.119 & 0.070 & \\
\hline $\mathrm{FCZOZ}$ & РТР-6 & -05 & ZIRLO-HH-1 & 9.130 & 8.35 & 9.497 & 9.520 & 8.21 & 0.111 & 0.070 & 1 \\
\hline $\mathrm{EC703}$ & TPRH 3 & 1613 & Zirc-4H-1 & o 720 & 8.36 & 9.477 & 9.485 & 8.21 & 0.120 & 0.075 & 1 \\
\hline FCLOS & КККН-3 & $10-13$ & ZIRLO-H-3 & 9.120 & 8.35 & 9.500 & 9.510 & 8.21 & 0.108 & 0.070 & 1 \\
\hline $\mathrm{EC7O4}$ & & & Zirc-4H-2 & & 8.36 & 9.477 & 9.483 & 8.20 & 0.122 & 0.080 & \\
\hline FCZO4 & РТP-6 & $0-15$ & ZIRLO-H-4 & 9.123 & 8.35 & 9.502 & 9.508 & 8.20 & 0.109 & 0.075 & 1 \\
\hline EC705 & $2-6$ & $16+2>$ & Zirc-4H-3 & 0 & 8.36 & 9.477 & 9.484 & 8.21 & 0.121 & 0.075 & 1 \\
\hline FCZOS & РТP-6 & $16-1$ & ZIRLO-H-5 & 9.122 & 8.35 & 9.502 & 9.507 & 8.18 & 0.109 & 0.085 & 1 \\
\hline
\end{tabular}




\subsubsection{Predicted Temperatures}

Figure 13 and Figure 14 show examples of temperature contours for the rabbit assembly and specimens for rabbits FCF04 and FCZ03, respectively. The FCF04 rabbit is in a TRRH-5 position, which is just above the core midplane. Therefore, there is a small $(<10 \%)$ reduction in heat generation moving from the bottom to the top of the rabbit. On the other hand, the bottom components are in direct contact with the cool bottom of the rabbit housing. The net effect is that the bottom specimen is at a slightly lower temperature than the top specimen, indicating that axial heat losses are more significant than the axial power profile effects. However, the effects of the axial variation in heat generation can be observed in the temperatures of the sleeves, centering thimbles, and wires. The FCZ03 rabbit is just below the core midplane. In this case, heat generation increases moving from the bottom to the top of the rabbit. Therefore, the effects of the axial variation in heat generation act in the same direction as the axial heat losses at the bottom of the rabbit. This explains why for rabbit FCZ03 the top sleeve and specimen are at higher temperatures compared to the bottom sleeve and specimen.

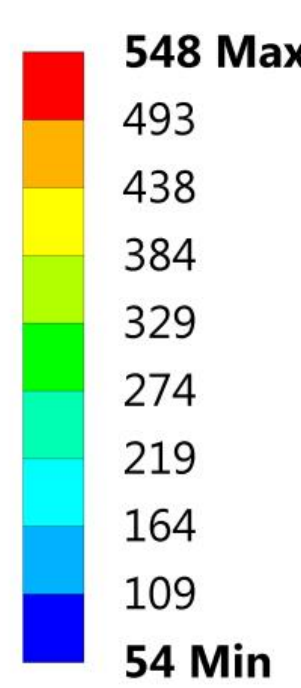

54 Min
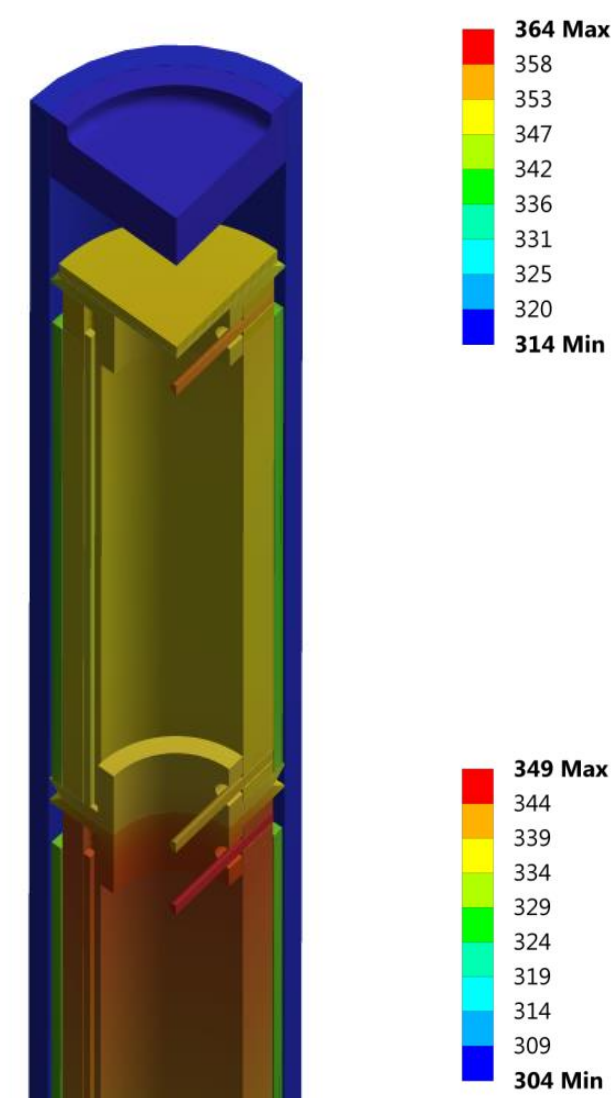


Figure 13. Temperature contours for the FCF04 rabbit assembly (left), bottom FeCrAl specimen (bottom right), and top FeCrAl specimen (top right). 

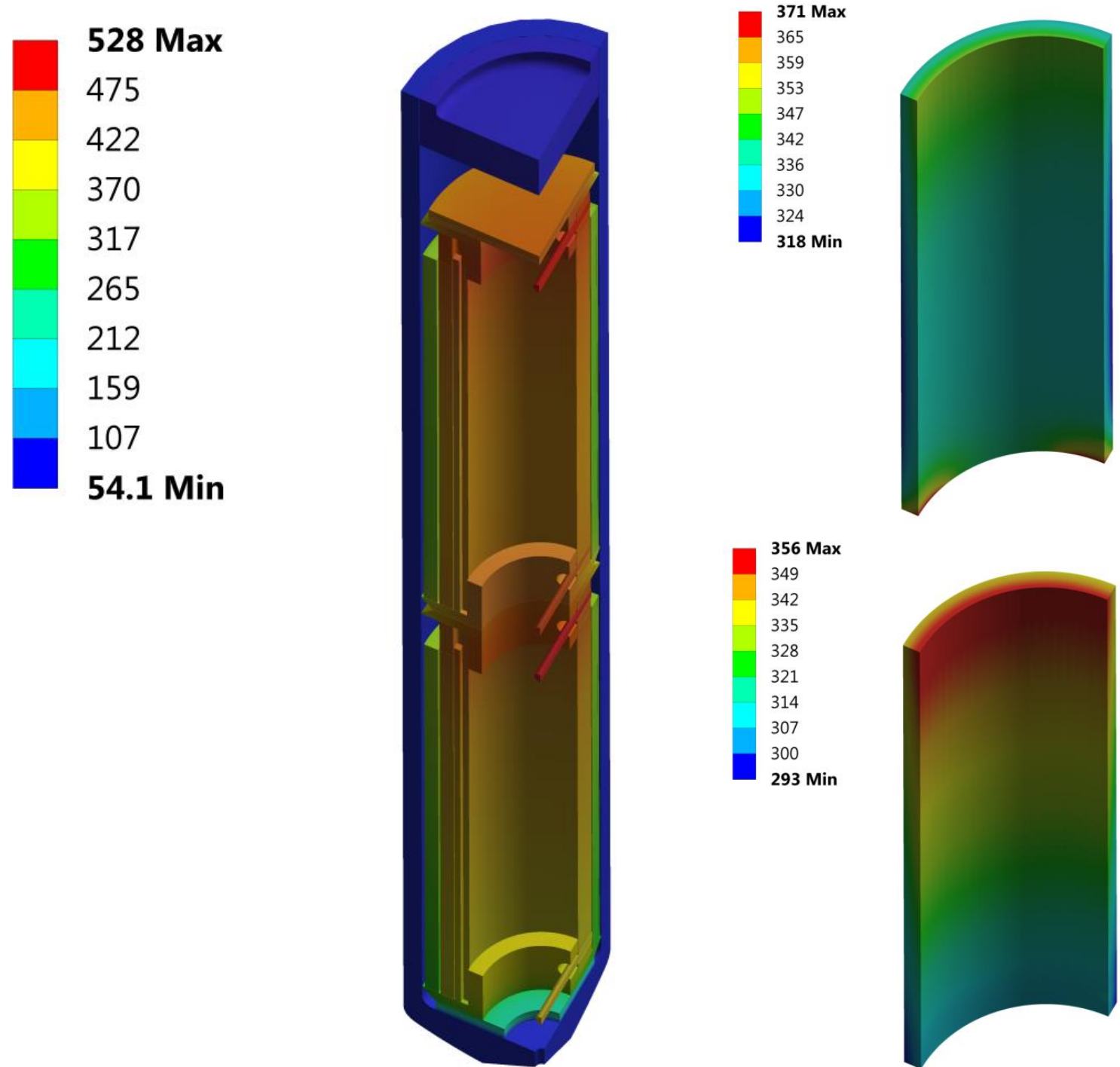

Figure 14. Temperature contours for the FCZ03 rabbit assembly (left), bottom Zr-alloy specimen (bottom right), and top $\mathrm{Zr}$-alloy specimen (top right).

Table 12 summarizes average, minimum, and maximum temperatures for the specimens in each rabbit capsule. Table 13 summarizes average, minimum, and maximum temperatures for the thermometry, which will be compared to temperatures determined post-irradiation using dilatometry. More details are provided in the full ANSYS output files that can be found in APPENDIX C. Average specimen temperatures range from $315-345^{\circ} \mathrm{C}$, which is within the desired range of $300-350^{\circ} \mathrm{C}$. Minimum temperatures are as low as $288^{\circ} \mathrm{C}$ at the bottom of the bottom-most specimen. Maximum temperatures are as high as $384^{\circ} \mathrm{C}$, although these temperatures are typically limited to small regions at the bottom of the top specimen close to the tabs of the centering thimbles. Although it was not explicitly modeled, closure of the sleeve-to-cladding gap due to sleeve swelling and (for Zr-alloy cladding) cladding growth will slightly increase the cladding temperatures, particularly for the bottom cladding specimen. The reason for this is that before gap closure there is some amount of heat generated in the sleeve that is lost due to conduction through the bottom centering thimble and the grafoil insulators. These heat losses reduce the amount of heat that is transferred to the cladding through the sleeve-to-cladding gas gap and thus reduce the cladding temperature. As the sleeve-to-cladding gap closes, heat will be more encouraged to pass through the sleeve-to-cladding gap instead of traveling down to the housing bottom, which will increase 
the heat flux through the cladding-to-housing gap and increase the cladding temperature. As a point of comparison, the top cladding specimen does not show significant axial temperature gradients, indicating that axial heat losses in the top specimen are negligible. Therefore, it is reasonable to assume that the temperature of the bottom cladding specimen will be somewhere between the calculated temperatures of the bottom and top specimens after sleeve-to-cladding gap closure.

Table 12. Predicted cladding temperatures for each rabbit

\begin{tabular}{|c|c|c|c|c|c|c|c|}
\hline \multirow{2}{*}{ Rabbit } & \multirow[b]{2}{*}{$\begin{array}{l}\text { Cladding } \\
\text { material }\end{array}$} & \multirow[b]{2}{*}{ Position } & \multirow[b]{2}{*}{ Не \% } & \multirow[b]{2}{*}{ Part } & \multicolumn{3}{|c|}{ Temperature $\left({ }^{\circ} \mathrm{C}\right)$} \\
\hline & & & & & Average & Minimum & Maximum \\
\hline \multirow[t]{2}{*}{ FCF01 } & $\mathrm{FeCrAl}$ & TRRH-3 & 92 & C06M-01 & 322 & 295 & 354 \\
\hline & & & & B136Y-1 & 345 & 332 & 384 \\
\hline \multirow{2}{*}{ FCF02 } & $\mathrm{FeCrAl}$ & TRRH-5 & 97 & C06M-02 & 317 & 293 & 343 \\
\hline & & & & B136Y-4 & 329 & 318 & 366 \\
\hline \multirow[t]{2}{*}{ FCF03 } & $\mathrm{FeCrAl}$ & TRRH-3 & 97 & B126Y-1 & 315 & 289 & 340 \\
\hline & & & & C36M3-4 & 330 & 317 & 364 \\
\hline \multirow[t]{2}{*}{ FCF04 } & $\mathrm{FeCrAl}$ & TRRH-5 & 97 & B126Y-2 & 328 & 304 & 349 \\
\hline & & & & C36M3-2 & 326 & 314 & 364 \\
\hline \multirow[t]{2}{*}{ FCF05 } & $\mathrm{FeCrAl}$ & TRRH-5 & 97 & B126Y-3 & 330 & 305 & 355 \\
\hline & & & & C36M3-3 & 318 & 307 & 363 \\
\hline \multirow[t]{2}{*}{ FCF06 } & $\mathrm{FeCrAl}$ & TRRH-5 & 97 & B126Y -4 & 324 & 301 & 347 \\
\hline & & & & C36M3-1 & 324 & 312 & 361 \\
\hline \multirow[t]{2}{*}{ FCZ01 } & Zr-alloy & TRRH-3 & 100 & Zirlo-1 & 316 & 288 & 344 \\
\hline & & & & ZIRLO-MH-1 & 331 & 311 & 375 \\
\hline \multirow[t]{2}{*}{ FCZ02 } & Zr-alloy & PTP-6 & 100 & Zirlo-2 & 341 & 312 & 367 \\
\hline & & & & ZIRLO-HH-1 & 336 & 322 & 383 \\
\hline \multirow[t]{2}{*}{ FCZ03 } & Zr-alloy & TRRH-3 & 100 & Zirc-4H-1 & 326 & 293 & 356 \\
\hline & & & & ZIRLO-H-3 & 332 & 318 & 371 \\
\hline \multirow[t]{2}{*}{ FCZ04 } & Zr-alloy & РTP-6 & 100 & Zirc-4H-2 & 344 & 314 & 369 \\
\hline & & & & ZIRLO-H-4 & 331 & 319 & 379 \\
\hline \multirow[t]{2}{*}{ FCZ05 } & Zr-alloy & PTP-6 & 100 & Zirc-4H-3 & 344 & 313 & 371 \\
\hline & & & & ZIRLO-H-5 & 328 & 317 & 377 \\
\hline
\end{tabular}


Table 13. Predicted passive temperature monitor (TM) temperatures for each rabbit

\begin{tabular}{|c|c|c|c|c|c|c|c|}
\hline \multirow{2}{*}{ Rabbit } & \multirow[b]{2}{*}{$\begin{array}{l}\text { Cladding } \\
\text { material }\end{array}$} & \multirow[b]{2}{*}{ Position } & \multirow[b]{2}{*}{$\begin{array}{l}\mathrm{He} \\
(\%)\end{array}$} & \multirow[b]{2}{*}{ Part } & \multicolumn{3}{|c|}{ Temperature $\left({ }^{\circ} \mathrm{C}\right)$} \\
\hline & & & & & Average & Minimum & Maximum \\
\hline \multirow[t]{2}{*}{ FCF01 } & $\mathrm{FeCrAl}$ & TRRH-3 & 92 & Bottom TM & 447 & 383 & 490 \\
\hline & & & & Top TM & 509 & 496 & 535 \\
\hline \multirow[t]{2}{*}{ FCF02 } & $\mathrm{FeCrAl}$ & TRRH-5 & 97 & Bottom TM & 444 & 385 & 477 \\
\hline & & & & Top TM & 445 & 439 & 463 \\
\hline \multirow[t]{2}{*}{ FCF03 } & $\mathrm{FeCrAl}$ & TRRH-3 & 97 & Bottom TM & 461 & 396 & 493 \\
\hline & & & & Top TM & 430 & 422 & 452 \\
\hline \multirow[t]{2}{*}{ FCF04 } & $\mathrm{FeCrAl}$ & TRRH-5 & 97 & Bottom TM & 474 & 411 & 500 \\
\hline & & & & Top TM & 416 & 409 & 435 \\
\hline \multirow[t]{2}{*}{ FCF05 } & $\mathrm{FeCrAl}$ & TRRH-5 & 97 & Bottom TM & 462 & 400 & 494 \\
\hline & & & & Top TM & 452 & 446 & 469 \\
\hline \multirow[t]{2}{*}{ FCF06 } & $\mathrm{FeCrAl}$ & TRRH-5 & 97 & Bottom TM & 471 & 409 & 497 \\
\hline & & & & Top TM & 414 & 407 & 432 \\
\hline \multirow[t]{2}{*}{ FCZ01 } & Zr-alloy & TRRH-3 & 100 & Bottom TM & 437 & 368 & 475 \\
\hline & & & & Top TM & 452 & 445 & 474 \\
\hline \multirow[t]{2}{*}{ FCZ02 } & Zr-alloy & PTP-6 & 100 & Bottom TM & 450 & 384 & 484 \\
\hline & & & & Top TM & 455 & 449 & 470 \\
\hline \multirow[t]{2}{*}{ FCZ03 } & Zr-alloy & TRRH-3 & 100 & Bottom TM & 430 & 362 & 469 \\
\hline & & & & Top TM & 458 & 451 & 480 \\
\hline \multirow[t]{2}{*}{ FCZ04 } & Zr-alloy & PTP-6 & 100 & Bottom TM & 458 & 389 & 492 \\
\hline & & & & Top TM & 462 & 456 & 476 \\
\hline \multirow[t]{2}{*}{ FCZ05 } & Zr-alloy & PTP-6 & 100 & Bottom TM & 453 & 386 & 489 \\
\hline & & & & Top TM & 470 & 465 & 485 \\
\hline
\end{tabular}

\section{SUMMARY AND CONCLUSIONS}

This work summarizes the capsule design, neutronic and thermal analyses, and flow testing that were performed to support the qualification of a new irradiation vehicle for testing representative PWR fuel cladding in the HFIR under relevant temperatures. This design allows for PIE of cladding that closely resembles expected commercially viable geometries and microstructures. PIE will include studies of dimensional change, microstructure variation, and mechanical performance for both advanced cladding materials (primarily $\mathrm{FeCrAl}$ alloys) and traditional $\mathrm{Zr}$-alloys, both with and without hydriding. The experiments were designed using relatively inexpensive HFIR rabbit capsules, which will allow for rapid testing of a large test matrix. Coupled MCNP + ORIGEN calculations were performed to give accurate estimates of neutron and gamma heating of the capsule components during irradiation. Thermal calculations were performed using finite-element analysis software to determine temperatures of the capsule components during irradiation. Inputs to these calculations include the calculated heating rates, geometry determined from high-precision dimensional inspection, and convection parameters determined from fluid dynamics calculations. Flow testing was performed to show that the new irradiation vehicles would have adequate cooling during irradiation. This work will help support the qualification of advanced fuel cladding materials, which will ultimately improve the accident tolerance of operating nuclear reactors. 


\section{WORKS CITED}

1. Northwood, D.O. and U. Kosasih, Hydrides and delayed hydrogen cracking in zirconium and its alloys, International Metals Reviews, 28 (1983) p. 92-121.

2. Cathcart, J.V., et al., Zirconium metal-water oxidation kinetics. IV. Reaction rate studies, ORNL/NUREG-17, Oak Ridge National Laboratory: Oak Ridge, TN (1977).

3. Garzarolli, F., et al. Oxide growth mechanism on zirconium alloys. in Zirconium in the Nuclear Industry: Ninth International Symposium. 1991. Kobe, Japan: ASTM International.

4. Zinkle, S.J., et al., Accident tolerant fuels for LWRs: A perspective, Journal of Nuclear Materials, 448 (2014) p. 374-379.

5. Pint, B.A., et al., Material Selection for Accident Tolerant Fuel Cladding, Metallurgical and Materials Transactions E, 2 (2014) p. 190-196.

6. Terrani, K.A., S.J. Zinkle, and L.L. Snead, Advanced Oxidation-Resistant Iron-Based Alloys for LWR Fuel Cladding, Journal of Nuclear Materials, 448 (2014) p. 420-435.

7. Yamamoto, Y., et al., Development and property evaluation of nuclear grade wrought FeCrAl fuel cladding for light water reactors, Journal of Nuclear Materials, 467 (2015) p. 703-716.

8. Rebak, R., Ferritic Alloys as Accident Tolerant Fuel Cladding Material for Light Water Reactors, Metallurgical and Materials Transactions E, 2 (2014) p. 74.

9. Field, K.G., et al., Database on Performance of Neutron Irradiated FeCrAl Alloys, ORNL/TM(2016/335, Oak Ridge National Laboratory: Oak Ridge, TN (2016).

10. Field, K.G., et al., Radiation Tolerance of Neutron-Irradiated Model Fe-Cr-Al Alloys, Journal of Nuclear Materials, 465 (2015) p. 746-755.

11. Field, K.G., et al., Heterogeneous dislocation loop formation near grain boundaries in a neutronirradiated commercial FeCrAl alloy, Journal of Nuclear Materials, 483 (2017) p. 54-61.

12. High Flux Isotope Reactor Technical Parameters. [cited 201627 July]; Available from: http://neutrons.ornl.gov/hfir/parameters.

13. Campbell, A., et al., Method for analyzing passive silicon carbide thermometry with a continuous dilatometer to determine irradiation temperature, Nuclear Instruments and Methods in Physics Research B, 370 (2016) p. 49-58.

14. Petrie, C.M., X3E020977A689, Rev. O, Target Capsule Housing Details, Oak Ridge National Laboratory: Oak Ridge, TN (2016).

15. Petrie, C.M., X3E020977A690, Rev. O, Target Capsule Housing Details, Oak Ridge National Laboratory: Oak Ridge, TN (2016).

16. McDuffee, J.L., X3E020977A634, Rev. B, Target Capsule Housing/End Cap Detail, Oak Ridge National Laboratory, Thermal Hydraulics and Irradiation Engineering Group: Oak Ridge, TN (2017).

17. Petrie, C.M., S16-10-FLEXCLAD01, Rev. 1, Flexible Cladding Rabbits Assembly, Oak Ridge National Laboratory: Oak Ridge, TN (2017).

18. Petrie, C.M., S16-11-FLEXCLAD02, Rev. 1, Flexible Cladding Rabbits Assembly and Part Details, Oak Ridge National Laboratory: Oak Ridge, TN (2017).

19. Xoubi, N. and R.T. Primm III, ORNL/TM-2004/251, Modeling of the High Flux Isotope Reactor Cycle 400, Oak Ridge, TN (2005).

20. McDuffee, J.L., Thermophysical Properties for AL6061, Oak Ridge National Laboratory, Thermal Hydraulics and Irradiation Engineering Group: Oak Ridge, TN (2013).

21. CINDAS, LLC: Global Benchmark for Critically Evaluated Materials Properties Data. 27 July [cited 201627 July]; Available from: http://cindasdata.com.

22. MatWeb: Material Property Data. MatWeb.com [cited 201627 July]; Available from: http://matweb.com/. 
23. Wahid, S.M.S. and C.V. Madhusudana, Gap conductance in contact heat transfer, International Journal of Heat and Mass Transfer, 43 (2000) p. 4483-4487.

24. McDuffee, J.L., DAC-10-03-PROP_AL6061, Rev.2, Thermophysical Properties for AL6061, Oak Ridge National Laboratory, Thermal Hydraulics and Irradiation Engineering Group: Oak Ridge, TN (2013).

25. Petrie, C.M., DAC-16-02-PROP_FeCrAl, Rev. O, Thermophysical Properties for FeCrAl, Oak Ridge National Laboratory: Oak Ridge, TN (2016).

26. McDuffee, J.L., DAC-11-03-PROP_ZIRCALOY, Rev. 2, Thermophysical Properties for Zircaloy, Oak Ridge National Laboratory: Oak Ridge, TN (2016).

27. McDuffee, J.L., DAC-11-14-PROP_TI6AL4V, Rev. 1, Thermophysical Properties for Titanium Alloy Ti-6Al4V, Oak Ridge National Laboratory: Oak Ridge, TN (2013).

28. McDuffee, J.L., DAC-11-16-PROP_GRAFOIL, Rev. O, Thermophysical Properties for Flexible Graphite, Oak Ridge National Laboratory: Oak Ridge, TN (2013).

29. McDuffee, J.L., DAC-10-06-PROP_SIC(IRR), Rev. 2, Thermophysical Properties for Irradiated $\mathrm{SiC}$, Oak Ridge National Laboratory, Thermal Hydraulics and Irradiation Engineering Group: Oak Ridge, TN (2013).

30. McDuffee, J.L., DAC-10-11-PROP_MOLY, Rev. 1, Thermophysical Properties for Molybdenum, Oak Ridge National Laboratory: Oak Ridge, TN (2013).

31. McDuffee, J.L., DAC-10-02-PROP_HELIUM, Rev. O, Thermophysical Properties for Helium, Oak Ridge National Laboratory, Thermal Hydraulics and Irradiation Engineering Group: Oak Ridge, TN (2010).

32. McDuffee, J.L., DAC-11-01-RAB03, Rev. O, Heat Transfer Coefficients and Bulk Temperatures for HFIR Rabbit Facilities, Oak Ridge National Laboratory, Thermal Hydraulics and Irradiation Engineering Group: Oak Ridge, TN (2011).

33. Daily, C., C-HFIR-2013-003, Rev. O, Heat Generation Rates for Various Titanium and Silicon Compounds in the Flux Trap of HFIR, Oak Ridge National Laboratory: Oak Ridge, TN (2013).

34. McDuffee, J.L., DAC-10-18-RAB02, Rev. 0, Heat Generation Rates for Various Rabbit Materials in the Flux Trap of HFIR, Oak Ridge National Laboratory, Thermal Hydraulics and Irradiation Engineering Group: Oak Ridge, TN (2011).

35. Howard, R.H., C-HFIR-2015-002, Rev. 0, FlowTest to Support Light Curium Targets in a Seven Hole Large VXF Holder, Oak RIdge National Laboratory: Oak RIdge, TN (2015).

36. Carbajo, J.J., C-HFIR-2001-026, Rev. 0, RELAP analysis of the PTT Irradiation Facility, Oak RIdge National Laboratory: (2002).

37. Hobbs, R.W., C-HFIR-1994-052, Rev. O, Calculation of target-region flow and pressure-drop perturbations due to increased use of solid dummy target rods, Oak Ridge National Laboratory: Oak Ridge, TN (1994).

38. Lide, D.R., Handbook of Chemistry and Physics: A Ready-Reference Book of Chemical and Phyical Data. 71st Edition ed, ed. R.C. Weast. 1990: CRC Press.

39. Ott, L.J., et al. Preparation of Prototypic Irradiated Hydrided-Zircaloy Cladding. in Proceedings of Top Fuel 2013. 2013. Charlotte.

40. Holt, R.A., Mechanisms of irradiation growth of alpha-zirconium alloys, Journal of Nuclear Materials, 159 (1988) p. 310-338.

41. Terrani, K.A., T.M. Karlsen, and Y. Yamamoto, Input Correlations for Irradiation Creep of FeCrAl and SiC Based on In-Pile Halden Test Results, ORNL/TM-2016/191, Oak Ridge National Laboratory: Oak Ridge, TN (2016).

42. Garner, F.A., M.B. Toloczko, and B.H. Sencer, Comparison of swelling and irradiation creep behavior of fcc-austenitic and bcc-ferritic/martensitic alloys at high neutron exposure, Journal of Nuclear Materials, 276 (2000) p. 123-142.

43. Cockeram, B.V., et al., The swelling, microstructure, and hardening of wrought LCAC, TZM, and ODS molybdenum following neutron irradiation, Journal of Nuclear Materials, 418 (2011) p. 121-136. 

APPENDIX A. SELECT ATTACHMENTS 



\section{APPENDIX A. SELECT ATTACHMENTS}

Exhibit 1 - Pressure Gauge Calibration

Pressure Gage Calibration Check: Omegadyne DPG409-100DWU (S/N 426085)

Fluke Model 718 300G Pressure Calibrator

\section{Range: $0-100$ psid}

ORNL Metrology ID No. A001516

Cal. Date:

$5 / 6 / 2016$

Cal. Due Date:

$5 / 6 / 2017$

Calibration by: J.R. Massengale $\quad 06 / 28 / 16$

Note: Pressure applied to high side of differential press ure transmitter, low side vented to atmos phere

\begin{tabular}{rcccc}
$\begin{array}{c}\text { Fluke Calibrator } \\
\begin{array}{c}\text { Applied Pressure } \\
\text { (psig) }\end{array}\end{array}$ & $\begin{array}{c}\text { DPT_1 } \\
\text { DAS Reading } \\
\text { (psid) }\end{array}$ & $\begin{array}{c}\text { Error } \\
\text { (psid) }\end{array}$ & Error (\%) & $\begin{array}{r}\text { Local } \\
\text { Display } \\
\text { (psig) }\end{array}$ \\
\cline { 3 - 4 } 0.00 & -0.03 & -0.03 & & 0.0 \\
5.00 & 4.95 & -0.05 & -1.0 & 5.0 \\
10.00 & 9.96 & -0.04 & -0.4 & 10.0 \\
15.00 & 14.96 & -0.04 & -0.3 & 15.0 \\
20.00 & 19.96 & -0.04 & -0.2 & 20.0 \\
30.00 & 29.96 & -0.04 & -0.1 & 30.0 \\
40.00 & 39.95 & -0.05 & -0.1 & 40.0 \\
50.00 & 49.95 & -0.05 & -0.1 & 50.0 \\
60.00 & 59.96 & -0.04 & -0.1 & 60.0 \\
70.00 & 69.95 & -0.05 & -0.1 & 70.0 \\
80.00 & 79.95 & -0.05 & -0.1 & 80.0 \\
90.00 & 89.94 & -0.06 & -0.1 & 90.0 \\
100.00 & 99.92 & -0.08 & -0.1 & 100.0 \\
50.00 & 49.95 & -0.05 & -0.1 & 50.0 \\
0.04 & -0.03 & -0.07 & & 0.0
\end{tabular}


Exhibit 2 - Flow Meter Calibration

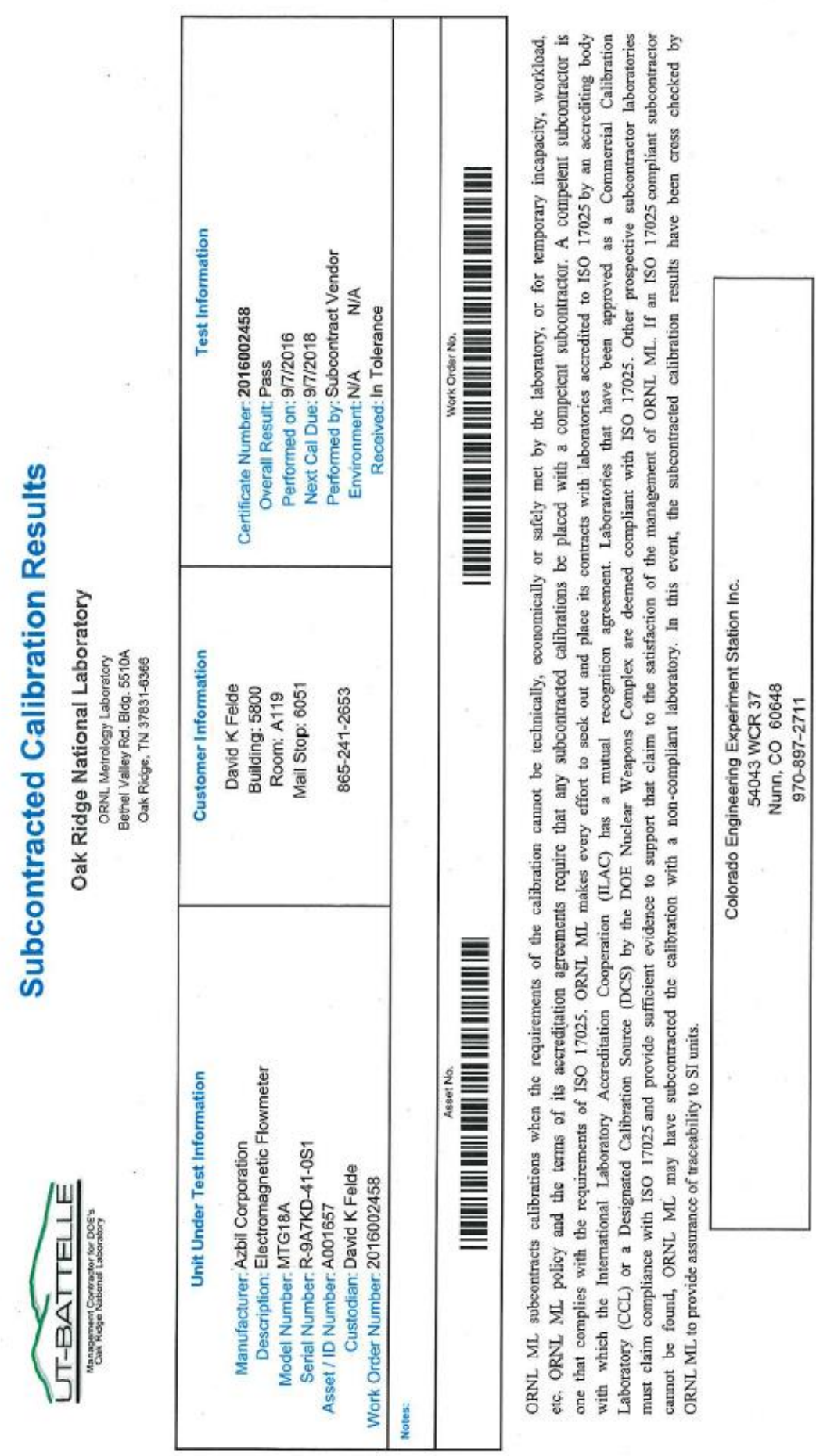




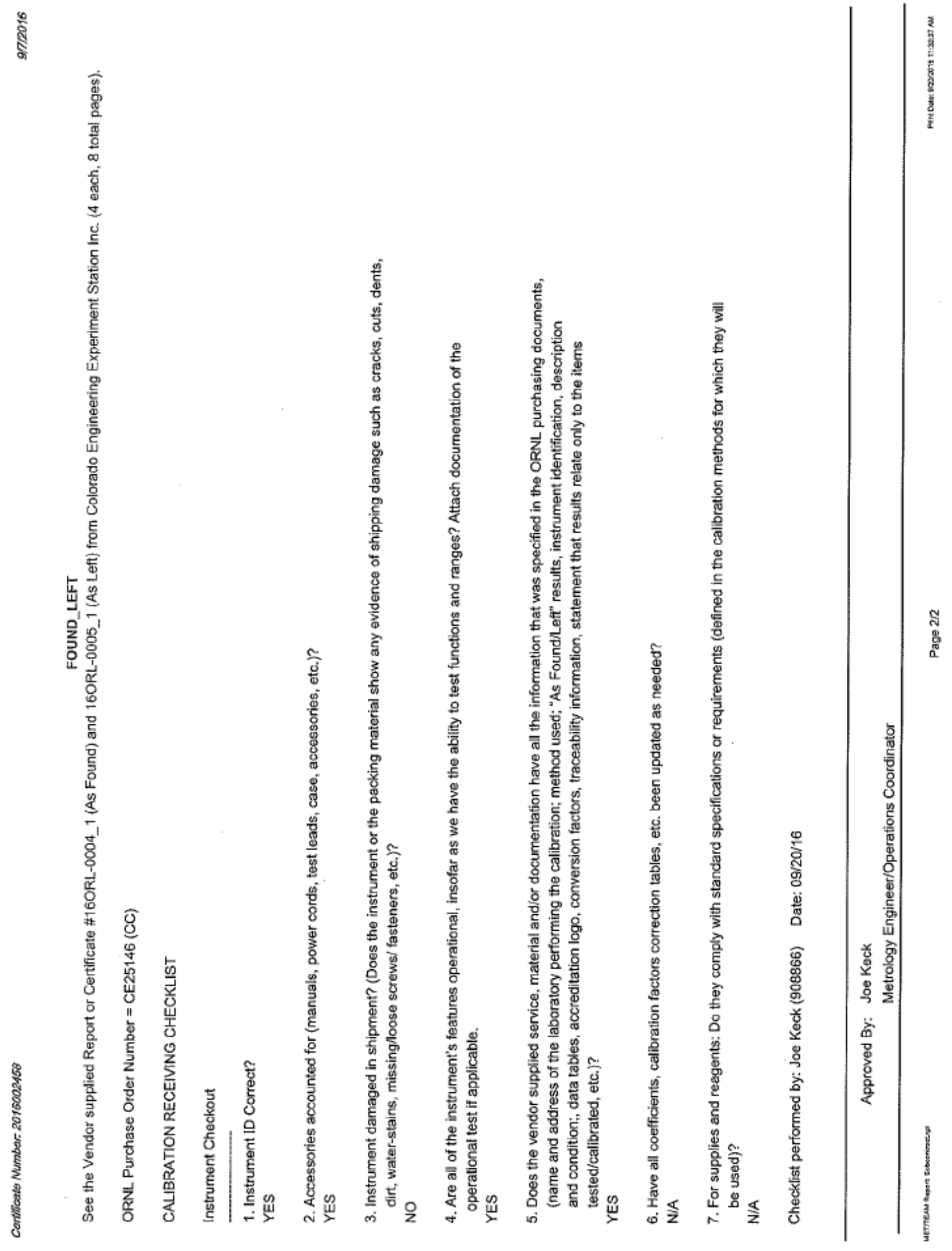




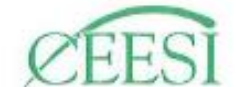

LABORATORY/OFFICE: 54043 County Rd, 37 Nunn, Colo. 80648 Phone: 970-897-2711

FAX: $970-897-2710$
COLORADO ENGINEERING EXPERIMENT STATION INC.

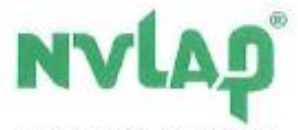

NVLAP LAB CODE 200377-0

\section{CERTIFICATE OF CALIBRATION \\ Traceable to the \\ NATIONAL INSTITUTE OF STANDARDS AND TECHNOLOGY}

\begin{tabular}{|c|c|c|c|}
\hline \multirow{3}{*}{$\begin{array}{l}\text { Customer: } \\
\text { Address: }\end{array}$} & Oak Ridge National Laboratory & Item Calibrated: & Magmet \\
\hline & 1 Bethel Valley Rd & & \\
\hline & Oak Ridge, TN 37831 & Serial Number: & R-9A7K \\
\hline Date: & September 07, 2016 & Order: & $\mathrm{CC}$ \\
\hline & 16ORL-0005_1 & Report Number: & \\
\hline
\end{tabular}

CEESI Data File(s): 16ORL-0005_1 Report Number:

The uncertainty in the flowrate indicated by CEESI standards is contained in this report under Statement of Uncertainties.

The calibration(s) identified by the above CEESI DATA FILE (S) were performed using standards that are traceable to the National Institute of Standards and Technology. The calibration(s) were performed in accordance with any or all of the following: The current revision of CEESI PROCEDURE NO. 10 ; NIST Handbook 150 (NVLAP accreditation under NVLAP lab code 200377-0); ISO/IEC 17025:1999; ANSI/NCSL Z540-1-1994; and Former MIL-STD-45662A. The stated uncertainties were calculated in accordance with the current revision of CEESI Report "Calibration Services Uncertainty Analyses".

Calibration Method

[X] Primary

This calibration is:

[ ] As Found



[ ] Secondary

[X] As Left

\section{NOTES:}

1. Re-calibration intervals should be determined by the user and based on meter type, conditions of use, and the degree of risk associated with the measurement. Please contact CEESI for guidance in establishing adequate recalibration intervals.

2. This Certificate and accompanying documentation shall not be reproduced, except in full, without the written consent of Colorado Enginecring Experiment Station Inc. The signing of the document does not claim or imply product certification, approval, or endorsement by NVLAP, NIST, CEESI, or any agency of the federal government.

CEESI Form $140 \quad 8.8 .06$ 


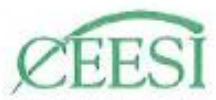

LABORATORY NOFFICE: 54043 County Fd. 37

Nunn, Cola 80648

Phon

FAX: 970-897-2710
COLORADO ENGINEERING EXPERIMENT STATION INC.

...the primary source for flow measurement solutions...

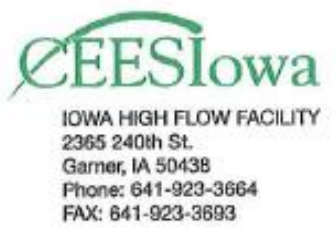

Phone: 641-923-3
Calibration of a Magmeter

Model: MTG18A-040P21LSDAAJT2-XX-X

For: Oak Ridge National Laboratory

Serial Number: R-9A7KD-41-0S1

Diameter: 1.610 Inches

Throat Diameter: 1.610 Inches

True Rate: gallons per minute, as measured by Static Weigh - Time - Temperature

MtrRead1: meter output in milliamps

Vel: Fluid velocity in feet per second

Temp: Temperature of fluid in degrees $F$

Rho: Density of fluid in pounds mass per cubic foot

Visc: Viscosity of fluid in pounds mass per inch seconds

MtrRead2: Meter panel output in gallons per minute

IndRate: (MtrRead1-Z)/16*30

Diff: TrueRate-IndPate

\begin{tabular}{cccccccccc} 
Pt. & $\begin{array}{c}\text { TrueRate } \\
\text { [gpm] }\end{array}$ & $\begin{array}{c}\text { MtrRead1 } \\
{[\mathrm{mA}]}\end{array}$ & $\begin{array}{c}\text { Vel } \\
{[\mathrm{ft} / \mathrm{sec}]}\end{array}$ & $\begin{array}{c}\text { Temp } \\
{\left[{ }^{\circ} \mathrm{F}\right]}\end{array}$ & $\begin{array}{c}\text { Rho } \\
{[\mathrm{lbm} / \mathrm{cuft}]}\end{array}$ & $\begin{array}{c}\text { Visc } \\
{\left[\mathrm{lbm} /\left(\mathrm{in}{ }^{*} \mathrm{sec}\right)\right]}\end{array}$ & $\begin{array}{c}\text { MtrRead2 } \\
{[\mathrm{gpm}]}\end{array}$ & $\begin{array}{c}\text { IndRate } \\
{[\mathrm{gpm}]}\end{array}$ & $\begin{array}{c}\text { Diff } \\
{[\mathrm{gpm}]}\end{array}$ \\
\hline \hline 1 & 30.259 & 20.142 & 4.77 & 85.751 & 62.167 & $4.478 \mathrm{E}-05$ & 30.280 & 30.265 & 0.006 \\
2 & 5.979 & 7.194 & 0.94 & 85.699 & 62.168 & $4.481 \mathrm{E}-05$ & 5.980 & 5.988 & 0.008 \\
3 & 27.029 & 18.429 & 4.26 & 85.706 & 62.167 & $4.480 \mathrm{E}-05$ & 27.030 & 27.054 & 0.025 \\
4 & 24.046 & 16.834 & 3.79 & 85.816 & 62.166 & $4.475 \mathrm{E}-05$ & 24.090 & 24.063 & 0.016 \\
5 & 20.907 & 15.159 & 3.29 & 85.804 & 62.166 & $4.475 \mathrm{E}-05$ & 20.930 & 20.921 & 0.014 \\
6 & 17.973 & 13.603 & 2.83 & 85.786 & 62.167 & $4.476 \mathrm{E}-05$ & 18.020 & 18.004 & 0.032 \\
7 & 14.973 & 12.000 & 2.36 & 85.774 & 62.167 & $4.477 \mathrm{E}-05$ & 15.030 & 14.999 & 0.025 \\
8 & 12.119 & 10.473 & 1.91 & 85.767 & 62.167 & $4.477 \mathrm{E}-05$ & 12.150 & 12.135 & 0.016 \\
9 & 9.166 & 8.893 & 1.44 & 85.741 & 62.167 & $4.478 \mathrm{E}-05$ & 9.200 & 9.174 & 0.008 \\
10 & 2.959 & 5.603 & 0.47 & 85.596 & 62.169 & $4.486 \mathrm{E}-05$ & 2.990 & 3.004 & 0.044
\end{tabular}




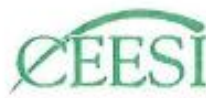

LABORATORYIOFFICE 54043 County Fid. 37 Nunn, Colo. 80348 Phone: $970-897-271$ FAX: $970-897-2710$
COLORADO ENGINEERING
EXPERIMENT STATION INC.

...the primary source for flow measurement solutions..

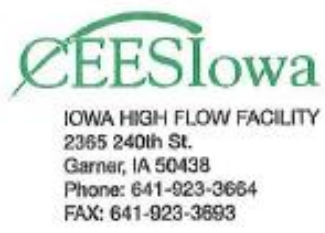

\section{STATEMENT OF UNCERTAINTIES}

Calibration of a Magmeter

Model: MTG18A-040P21LSDAAJT2-XX-X

For: Oak Ridge National Laboratory

Serial Number: R-9A7KD-41-0S1

Data File: 16ORL-0005_1 Job Number: CE25146 Date: 07 September 2016

Inlet Diameter: 1.610 Inches Throat Diameter: 1.610 Inches

Test Fluid: WATER

TrueRate: Uncertainty in volumetric flowrate at a $95 \%$ confidence in percent of reading

MtrRead1: Uncertainty in milliamps at a $95 \%$ confidence in percent of reading

Vel: Uncertainty in velocity at a $95 \%$ confidence in percent of reading

Temp: Uncertainty in temperature at a $95 \%$ confidence in percent of reading

Rho: Uncertainty in density at a $95 \%$ confidence in percent of reading

Visc: Uncertainty in viscosity at a $95 \%$ confidence in percent of reading

MtrRead2: -

IndRate: -

Diff: -

\begin{tabular}{cccccccccc} 
Pt. & $\begin{array}{c}\text { TrueRate } \\
{[\%]}\end{array}$ & $\begin{array}{c}\text { MtrRead1 } \\
{[\%]}\end{array}$ & $\begin{array}{c}\text { Vel } \\
{[\%]}\end{array}$ & $\begin{array}{c}\text { Temp } \\
{[\%]}\end{array}$ & $\begin{array}{c}\text { Rho } \\
{[\%]}\end{array}$ & $\begin{array}{c}\text { Visc } \\
{[\%]}\end{array}$ & MtrRead2 & IndRate & Diff \\
\hline 1 & 0.12 & 0.017 & 0.12 & 0.034 & 0.060 & 0.25 & - & - & - \\
2 & 0.12 & 0.017 & 0.12 & 0.034 & 0.060 & 0.25 & - & - & - \\
3 & 0.12 & 0.017 & 0.12 & 0.034 & 0.060 & 0.25 & - & - & - \\
4 & 0.12 & 0.017 & 0.12 & 0.034 & 0.060 & 0.25 & - & - & - \\
5 & 0.12 & 0.017 & 0.12 & 0.034 & 0.060 & 0.25 & - & - & - \\
6 & 0.12 & 0.017 & 0.12 & 0.034 & 0.060 & 0.25 & - & - & - \\
7 & 0.12 & 0.017 & 0.12 & 0.034 & 0.060 & 0.25 & - & - & - \\
8 & 0.12 & 0.017 & 0.12 & 0.034 & 0.060 & 0.25 & - & - & - \\
9 & 0.12 & 0.017 & 0.12 & 0.034 & 0.060 & 0.25 & - & - & - \\
10 & 0.12 & 0.017 & 0.12 & 0.034 & 0.060 & 0.25 & - & - & -
\end{tabular}




\section{CEESI}

LABORATORYOFFICE

54043 County RA 37

Man, Colo. 80078

FAX: $970-897-2710$

Calibration Checklist

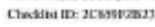

Job 耑: CE25146

R-9A7KD-4l-0S।

Moslel $\mathrm{H}$ :

MTGI8A-04IP2ILSDAATT2 XX-X

Meter Type: MAGMETER

Descriptions 1.5

S: Inlet Pressure, Inlet Temperntu

Data Aequisition: CEESI047

List of Instruments Used:

OC Number Instrument Description Cal. Due Date

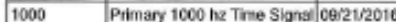

\begin{tabular}{l|l}
1564 & $D A Q$
\end{tabular}

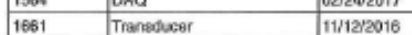

\begin{tabular}{|l|l|l|}
\hline 1661 & Thanhobsar & 11/12/2016 \\
\hline 1780 & 70 digital scalo & $02 / 07 / 2017$ \\
\hline
\end{tabular}

\begin{tabular}{|l|l|l|}
\hline 1782 & $12001 \mathrm{~b}$ d gital scailo & $02 / 07 / 2017$ \\
\hline
\end{tabular}

List of Standards Used:

\section{Standerd(s) Number}

Prom.3

PAIIL2

Quality Control Supervisar: John Reiner on 9/72016
厄EESIowa

IOWA HLGHFOWFACHITY

2365240 th $5 t$.

Gamer, LA S0438

FAX: 641-923-3693 


\begin{tabular}{|c|c|c|c|c|}
\hline . & LENGTH & $O D$ & $\begin{array}{l}\text { (Housin6) } \\
\text { MAss }\end{array}$ & $\begin{array}{l}\text { TOTAL } \\
\text { MASS }\end{array}$ \\
\hline Test 1 & 2.521 & .442 & $4.655 \mathrm{~g}$ & $15.591 \mathrm{~g}$ \\
\hline Test 2 & 2.522 & .442 & $4.64 \phi \mathrm{g}$ & $15.689 \mathrm{~g}$ \\
\hline TEST 3 & 2.521 & .442 & $4.651 \mathrm{~g}$ & $15.763 \mathrm{~g}$ \\
\hline Tesi 4 & 2.521 & .442 & $4.652 \mathrm{~g}$ & $15.762 \mathrm{~g}$ \\
\hline TEST 5 & 2.522 & .441 & 4.6659 & $15.749 \mathrm{~s}$ \\
\hline TKST 6 & 2.521 & .442 & $4.649 \mathrm{~s}$ & $15.673 \mathrm{~g}$ \\
\hline Test 7 & 2.522 & .442 & $4.641 \mathrm{~g}$ & 15.728 \\
\hline & & & & - \\
\hline & LEVGTH & $O D$ & MASS & \\
\hline TEST 1 & 2.094 & .378 & $10.4 \phi 7 \mathrm{~g}$ & \\
\hline Tesr 2 & 2.126 & .379 & $10.535 \mathrm{~g}$ & \\
\hline $\operatorname{Tes} 3$ & 2.126 & .378 & 10.534, & \\
\hline TEST 4 & 2.123 & .377 & 10.535 & \\
\hline Test 5 & 2.119 & .379 & 10.528 & \\
\hline Test 6 & 2.116 & .378 & 10.568 & \\
\hline Tos 7 & 2.128 & .378 & 10.571 & \\
\hline & & & 1). $l e$ & \\
\hline & & & $10 k$ & \\
\hline & & & & \\
\hline
\end{tabular}

\section{Lengths and outer diameters (ODs) in inches}




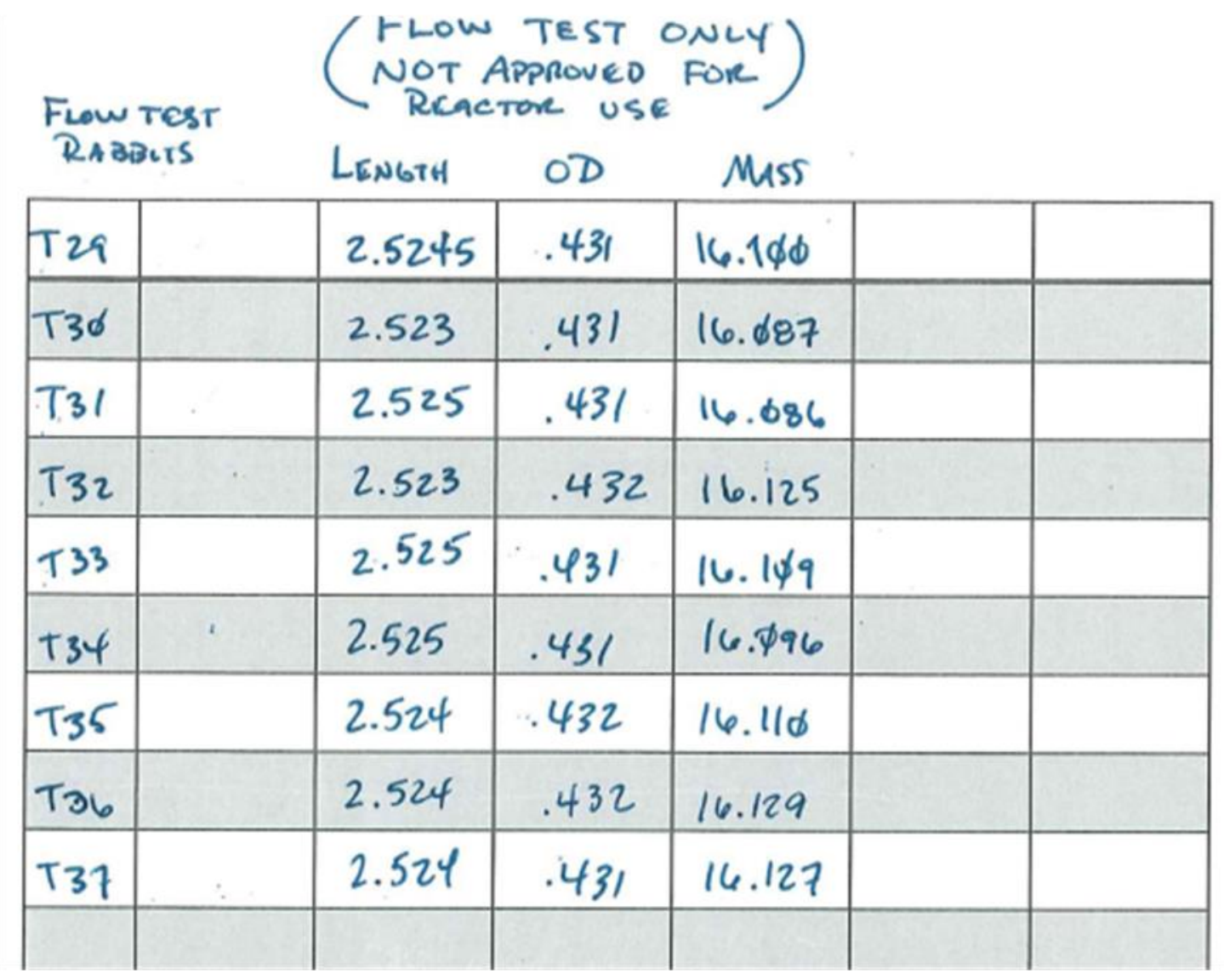

Lengths and outer diameters (ODs) in inches, mass in grams 
Outer surface

Rabbit housing roughness ( $R a)$

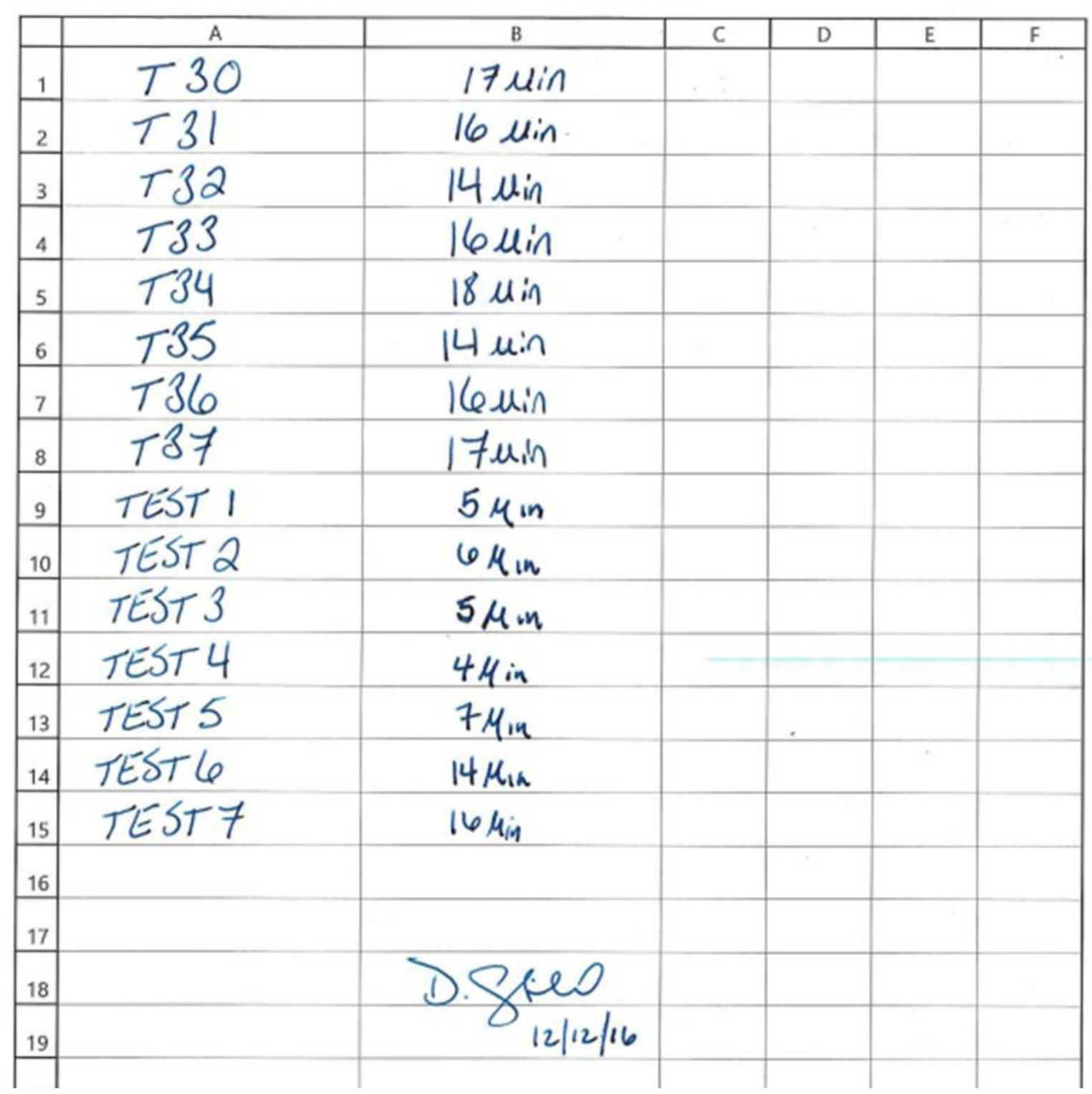

A-12 


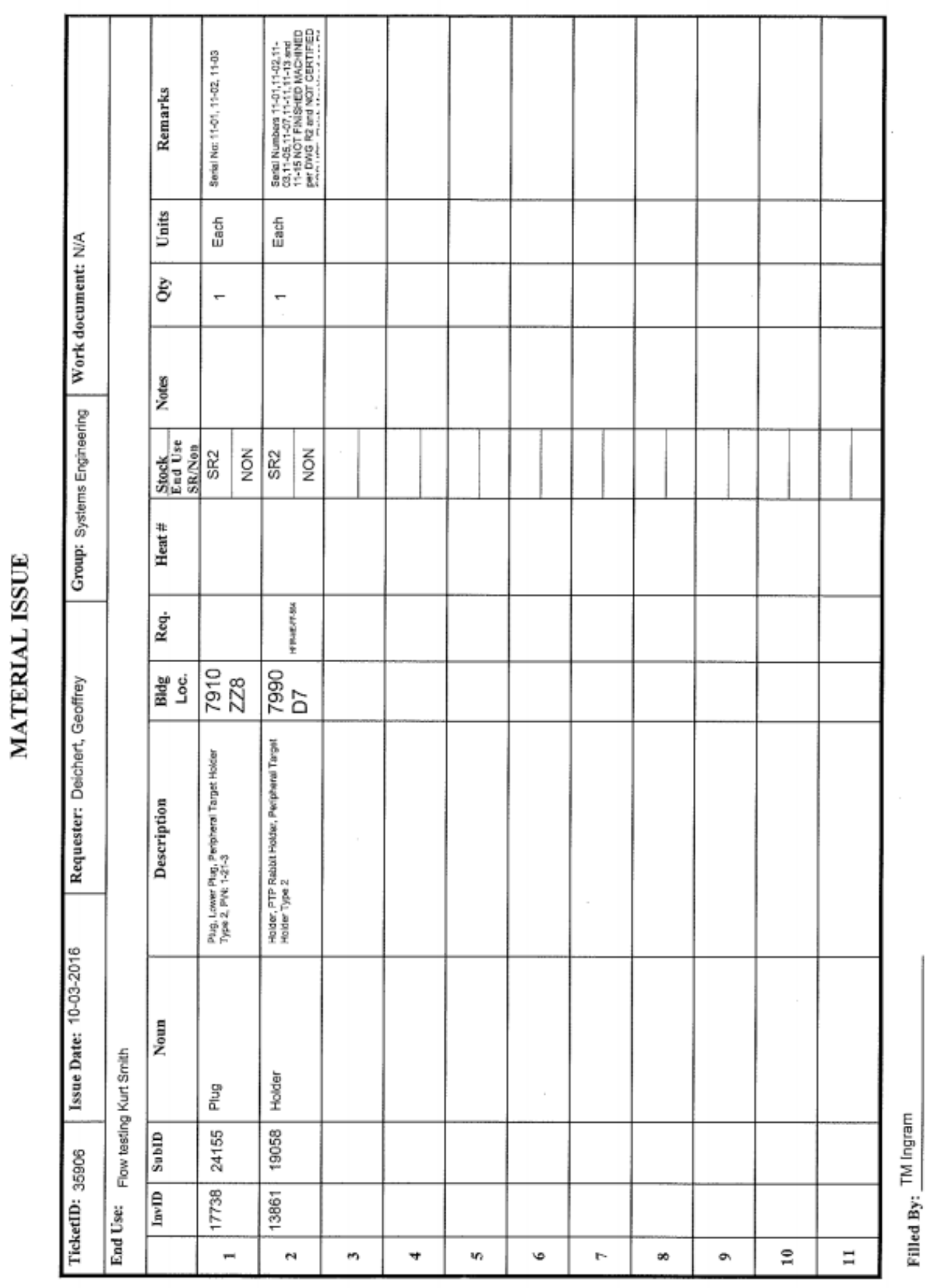



APPENDIX B. DIMENSIONAL INSPECTION 



\section{APPENDIX B. DIMENSIONAL INSPECTION}

Table B-1. Cladding dimensions

\begin{tabular}{|c|c|c|c|c|c|c|c|c|c|}
\hline Material & $\underset{\#}{\text { Cladding Part }}$ & $\begin{array}{c}\text { ID } \\
(\mathbf{m m})\end{array}$ & $\begin{array}{c}\text { Minor } \\
\text { OD } \\
(\mathbf{m m})\end{array}$ & $\begin{array}{c}\text { Major } \\
\text { OD } \\
(\mathrm{mm})\end{array}$ & $\begin{array}{c}\text { Avg } \\
\text { OD } \\
(\mathrm{mm})\end{array}$ & $\begin{array}{c}\text { Min } \\
\text { OD } \\
(\mathbf{m m})\end{array}$ & $\begin{array}{c}\text { Max } \\
\text { OD } \\
(\mathbf{m m})\end{array}$ & $\begin{array}{l}\text { Length } \\
(\mathrm{mm})\end{array}$ & $\begin{array}{c}\text { Avg } \\
\text { length } \\
(\mathrm{mm})\end{array}$ \\
\hline $\mathrm{FeCrAl}$ & C06M-01 & 8.79 & 9.526 & 9.534 & 9.533 & 9.526 & 9.549 & 15.897 & 15.885 \\
\hline \multirow[t]{5}{*}{$\mathrm{C} 06 \mathrm{M}$} & C06M-01 & & 9.528 & 9.534 & & & & 15.875 & \\
\hline & C06M-01 & & 9.530 & 9.536 & & & & 15.878 & \\
\hline & C06M-01 & & 9.528 & 9.539 & & & & 15.890 & \\
\hline & C06M-01 & & 9.526 & 9.549 & & & & & \\
\hline & C06M-01 & & & & & & & & \\
\hline $\mathrm{FeCrAl}$ & C06M-02 & 8.79 & 9.508 & 9.532 & 9.527 & 9.508 & 9.535 & 15.747 & 15.750 \\
\hline \multirow[t]{5}{*}{$\mathrm{C06M}$} & C06M-02 & & 9.526 & 9.535 & & & & 15.751 & \\
\hline & C06M-02 & & 9.525 & 9.535 & & & & 15.747 & \\
\hline & C06M-02 & & 9.526 & 9.533 & & & & 15.756 & \\
\hline & C06M-02 & & 9.519 & 9.531 & & & & & \\
\hline & C06M-02 & & & & & & & & \\
\hline $\mathrm{FeCrAl}$ & B126Y-1 & 8.76 & 9.497 & 9.521 & 9.509 & 9.493 & 9.522 & 23.502 & 23.498 \\
\hline \multirow[t]{5}{*}{ B126Y } & B126Y-1 & & 9.500 & 9.518 & & & & 23.495 & \\
\hline & B126Y-1 & & 9.501 & 9.522 & & & & 23.502 & \\
\hline & B126Y-1 & & 9.501 & 9.522 & & & & 23.494 & \\
\hline & B126Y-1 & & 9.498 & 9.521 & & & & & \\
\hline & B126Y-1 & & 9.493 & 9.517 & & & & & \\
\hline $\mathrm{FeCrAl}$ & B126Y-2 & 8.76 & 9.501 & 9.511 & 9.509 & 9.500 & 9.519 & 23.481 & 23.481 \\
\hline \multirow[t]{5}{*}{ B126Y } & B126Y-2 & & 9.504 & 9.514 & & & & 23.481 & \\
\hline & B126Y-2 & & 9.506 & 9.514 & & & & 23.482 & \\
\hline & B126Y-2 & & 9.504 & 9.519 & & & & 23.480 & \\
\hline & B126Y-2 & & 9.503 & 9.516 & & & & & \\
\hline & B126Y-2 & & 9.500 & 9.518 & & & & & \\
\hline $\mathrm{FeCrAl}$ & B126Y-3 & 8.76 & 9.505 & 9.515 & 9.510 & 9.501 & 9.518 & 23.304 & 23.305 \\
\hline \multirow[t]{5}{*}{ B126Y } & B126Y-3 & & 9.502 & 9.516 & & & & 23.307 & \\
\hline & B126Y-3 & & 9.502 & 9.518 & & & & 23.302 & \\
\hline & B126Y-3 & & 9.501 & 9.518 & & & & 23.307 & \\
\hline & B126Y-3 & & 9.504 & 9.517 & & & & & \\
\hline & B126Y-3 & & 9.501 & 9.518 & & & & & \\
\hline $\mathrm{FeCrAl}$ & B126Y-4 & 8.76 & 9.500 & 9.520 & 9.511 & 9.500 & 9.524 & 23.406 & 23.410 \\
\hline \multirow[t]{5}{*}{ B126Y } & B126Y-4 & & 9.500 & 9.518 & & & & 23.417 & \\
\hline & B126Y-4 & & 9.500 & 9.522 & & & & 23.408 & \\
\hline & B126Y-4 & & 9.500 & 9.520 & & & & 23.408 & \\
\hline & B126Y-4 & & 9.501 & 9.518 & & & & & \\
\hline & B126Y-4 & & 9.504 & 9.524 & & & & & \\
\hline
\end{tabular}




\begin{tabular}{|c|c|c|c|c|c|c|c|c|c|}
\hline Material & $\underset{\#}{\text { Cladding Part }}$ & $\begin{array}{c}\text { ID } \\
(\mathbf{m m})\end{array}$ & $\begin{array}{c}\text { Minor } \\
\text { OD } \\
(\mathbf{m m})\end{array}$ & $\begin{array}{c}\text { Major } \\
\text { OD } \\
(\mathbf{m m})\end{array}$ & $\begin{array}{c}\text { Avg } \\
\text { OD } \\
(\mathbf{m m})\end{array}$ & $\begin{array}{c}\text { Min } \\
\text { OD } \\
(\mathbf{m m})\end{array}$ & $\begin{array}{c}\text { Max } \\
\text { OD } \\
(\mathbf{m m})\end{array}$ & $\begin{array}{c}\text { Length } \\
(\mathbf{m m})\end{array}$ & $\begin{array}{c}\text { Avg } \\
\text { length } \\
(\mathbf{m m})\end{array}$ \\
\hline $\mathrm{FeCrAl}$ & C36M3-1 & 8.79 & 9.530 & 9.538 & 9.535 & 9.530 & 9.539 & 23.355 & 23.359 \\
\hline \multirow[t]{5}{*}{ C36M3 } & C36M3-1 & & 9.530 & 9.538 & & & & 23.363 & \\
\hline & C36M3-1 & & 9.531 & 9.538 & & & & 23.364 & \\
\hline & C36M3-1 & & 9.533 & 9.538 & & & & 23.352 & \\
\hline & C36M3-1 & & 9.533 & 9.537 & & & & & \\
\hline & C36M3-1 & & 9.532 & 9.539 & & & & & \\
\hline $\mathrm{FeCrAl}$ & C36M3-2 & 8.79 & 9.530 & 9.539 & 9.535 & 9.530 & 9.540 & 23.429 & 23.423 \\
\hline \multirow{5}{*}{ C36M3 } & C36M3-2 & & 9.530 & 9.540 & & & & 23.426 & \\
\hline & C36M3-2 & & 9.531 & 9.538 & & & & 23.416 & \\
\hline & C36M3-2 & & 9.533 & 9.539 & & & & 23.419 & \\
\hline & C36M3-2 & & 9.531 & 9.539 & & & & & \\
\hline & C36M3-2 & & 9.531 & 9.536 & & & & & \\
\hline $\mathrm{FeCrAl}$ & C36M3-3 & 8.77 & 9.536 & 9.541 & 9.535 & 9.528 & 9.541 & 23.363 & 23.364 \\
\hline \multirow[t]{5}{*}{ C36M3 } & C36M3-3 & & 9.529 & 9.537 & & & & 23.351 & \\
\hline & C36M3-3 & & 9.530 & 9.539 & & & & 23.380 & \\
\hline & C36M3-3 & & 9.531 & 9.541 & & & & 23.360 & \\
\hline & C36M3-3 & & 9.528 & 9.536 & & & & & \\
\hline & C36M3-3 & & 9.530 & 9.539 & & & & & \\
\hline $\mathrm{FeCrAl}$ & C36M3-4 & 8.79 & 9.526 & 9.534 & 9.533 & 9.526 & 9.538 & 23.495 & 23.494 \\
\hline \multirow[t]{5}{*}{ C36M3 } & C36M3-4 & & 9.528 & 9.537 & & & & 23.499 & \\
\hline & C36M3-4 & & 9.530 & 9.538 & & & & 23.492 & \\
\hline & C36M3-4 & & 9.532 & 9.538 & & & & 23.489 & \\
\hline & C36M3-4 & & 9.532 & 9.536 & & & & & \\
\hline & C36M3-4 & & 9.530 & 9.535 & & & & & \\
\hline $\mathrm{FeCrAl}$ & B136Y-1 & 8.78 & 9.526 & 9.531 & 9.528 & 9.517 & 9.535 & 23.401 & 23.399 \\
\hline \multirow[t]{5}{*}{ B136Y } & B136Y-1 & & 9.528 & 9.533 & & & & 23.401 & \\
\hline & B136Y-1 & & 9.528 & 9.533 & & & & 23.402 & \\
\hline & B136Y-1 & & 9.524 & 9.535 & & & & 23.391 & \\
\hline & B136Y-1 & & 9.522 & 9.531 & & & & & \\
\hline & B136Y-1 & & 9.517 & 9.527 & & & & & \\
\hline $\mathrm{FeCrAl}$ & B136Y-4 & 8.79 & 9.520 & 9.525 & 9.526 & 9.516 & 9.533 & 23.348 & 23.356 \\
\hline \multirow[t]{5}{*}{ B136Y } & B136Y-4 & & 9.524 & 9.529 & & & & 23.358 & \\
\hline & B136Y-4 & & 9.523 & 9.531 & & & & 23.358 & \\
\hline & B136Y-4 & & 9.523 & 9.533 & & & & 23.360 & \\
\hline & B136Y-4 & & 9.521 & 9.532 & & & & & \\
\hline & B136Y-4 & & 9.516 & 9.533 & & & & & \\
\hline \multirow[t]{3}{*}{ ZIRLO } & Zirlo-1 & 8.35 & 9.487 & 9.495 & 9.493 & 9.484 & 9.499 & 23.350 & 23.374 \\
\hline & Zirlo-1 & & 9.491 & 9.499 & & & & 23.388 & \\
\hline & Zirlo-1 & & 9.493 & 9.498 & & & & 23.375 & \\
\hline
\end{tabular}




\begin{tabular}{|c|c|c|c|c|c|c|c|c|c|}
\hline Material & $\underset{\#}{\text { Cladding Part }}$ & $\begin{array}{c}\text { ID } \\
(\mathbf{m m})\end{array}$ & $\begin{array}{c}\text { Minor } \\
\text { OD } \\
(\mathrm{mm})\end{array}$ & $\begin{array}{c}\text { Major } \\
\text { OD } \\
(\mathbf{m m})\end{array}$ & $\begin{array}{c}\text { Avg } \\
\text { OD } \\
(\mathbf{m m})\end{array}$ & $\begin{array}{c}\text { Min } \\
\text { OD } \\
(\mathbf{m m})\end{array}$ & $\begin{array}{c}\text { Max } \\
\text { OD } \\
(\mathbf{m m})\end{array}$ & $\begin{array}{c}\text { Length } \\
(\mathbf{m m})\end{array}$ & $\begin{array}{c}\text { Avg } \\
\text { length } \\
(\mathbf{m m})\end{array}$ \\
\hline & Zirlo-1 & & 9.493 & 9.498 & & & & 23.382 & \\
\hline & Zirlo-1 & & 9.493 & 9.497 & & & & & \\
\hline & Zirlo-1 & & 9.484 & 9.491 & & & & & \\
\hline \multirow[t]{6}{*}{ ZIRLO } & Zirlo-2 & 8.35 & 9.485 & 9.490 & 9.493 & 9.485 & 9.502 & 23.429 & 23.436 \\
\hline & Zirlo-2 & & 9.491 & 9.495 & & & & 23.459 & \\
\hline & Zirlo-2 & & 9.495 & 9.500 & & & & 23.423 & \\
\hline & Zirlo-2 & & 9.493 & 9.499 & & & & 23.432 & \\
\hline & Zirlo-2 & & 9.493 & 9.502 & & & & & \\
\hline & Zirlo-2 & & 9.485 & 9.491 & & & & & \\
\hline ZIRLO & Zirlo-HH-1 & 8.35 & 9.491 & 9.550 & 9.508 & 9.491 & 9.550 & 23.510 & 23.476 \\
\hline $1000 \mathrm{wt}$ & Zirlo-HH-1 & & 9.495 & 9.524 & & & & 23.433 & \\
\hline \multirow[t]{4}{*}{ ppm H } & Zirlo-HH-1 & & 9.495 & 9.512 & & & & 23.506 & \\
\hline & Zirlo-HH-1 & & 9.497 & 9.508 & & & & 23.455 & \\
\hline & Zirlo-HH-1 & & 9.501 & 9.504 & & & & & \\
\hline & Zirlo-HH-1 & & 9.501 & 9.522 & & & & & \\
\hline ZIRLO & Zirlo-MH-1 & 8.37 & 9.488 & 9.531 & 9.511 & 9.483 & 9.537 & 23.445 & 23.476 \\
\hline $500 \mathrm{wt}$ & Zirlo-MH-1 & & 9.487 & 9.537 & & & & 23.508 & \\
\hline \multirow[t]{4}{*}{ ppm H } & Zirlo-MH-1 & & 9.487 & 9.535 & & & & 23.447 & \\
\hline & Zirlo-MH-1 & & 9.488 & 9.536 & & & & 23.503 & \\
\hline & Zirlo-MH-1 & & 9.487 & 9.533 & & & & & \\
\hline & Zirlo-MH-1 & & 9.483 & 9.537 & & & & & \\
\hline Zircaloy-4 & Zirc-4H-1 & 8.36 & 9.474 & 9.481 & 9.481 & 9.474 & 9.487 & 23.467 & 23.475 \\
\hline $150 \mathrm{wt}$ & Zirc-4H-1 & & 9.478 & 9.487 & & & & 23.458 & \\
\hline \multirow[t]{4}{*}{ ppm H } & Zirc-4H-1 & & 9.475 & 9.482 & & & & 23.515 & \\
\hline & Zirc-4H-1 & & 9.482 & 9.487 & & & & 23.458 & \\
\hline & Zirc-4H-1 & & 9.478 & 9.486 & & & & & \\
\hline & Zirc-4H-1 & & 9.477 & 9.487 & & & & & \\
\hline Zircaloy-4 & Zirc-4H-2 & 8.36 & 9.479 & 9.484 & 9.480 & 9.474 & 9.486 & 23.438 & 23.434 \\
\hline $150 \mathrm{wt}$ & Zirc-4H-2 & & 9.476 & 9.483 & & & & 23.440 & \\
\hline \multirow[t]{4}{*}{ ppm H } & Zirc-4H-2 & & 9.477 & 9.482 & & & & 23.429 & \\
\hline & Zirc-4H-2 & & 9.478 & 9.486 & & & & 23.430 & \\
\hline & Zirc-4H-2 & & 9.476 & 9.482 & & & & & \\
\hline & Zirc-4H-2 & & 9.474 & 9.482 & & & & & \\
\hline Zircaloy-4 & Zirc-4H-3 & 8.36 & 9.476 & 9.484 & 9.481 & 9.476 & 9.486 & 23.441 & 23.437 \\
\hline $150 \mathrm{wt}$ & Zirc-4H-3 & & 9.477 & 9.485 & & & & 23.434 & \\
\hline \multirow[t]{4}{*}{ ppm H } & Zirc-4H-3 & & 9.479 & 9.486 & & & & 23.441 & \\
\hline & Zirc-4H-3 & & 9.478 & 9.484 & & & & 23.430 & \\
\hline & Zirc-4H-3 & & 9.476 & 9.482 & & & & & \\
\hline & Zirc-4H-3 & & 9.476 & 9.484 & & & & & \\
\hline ZIRLO & ZIRLO-H-3 & 8.35 & 9.497 & 9.512 & 9.505 & 9.497 & 9.512 & 23.563 & 23.511 \\
\hline
\end{tabular}




\begin{tabular}{|c|c|c|c|c|c|c|c|c|c|}
\hline Material & $\begin{array}{c}\text { Cladding Part } \\
\#\end{array}$ & $\begin{array}{c}\text { ID } \\
(\mathbf{m m})\end{array}$ & $\begin{array}{c}\text { Minor } \\
\text { OD } \\
(\mathbf{m m})\end{array}$ & $\begin{array}{c}\text { Major } \\
\text { OD } \\
(\mathbf{m m})\end{array}$ & $\begin{array}{c}\text { Avg } \\
\text { OD } \\
(\mathbf{m m})\end{array}$ & $\begin{array}{c}\text { Min } \\
\text { OD } \\
(\mathbf{m m})\end{array}$ & $\begin{array}{c}\text { Max } \\
\text { OD } \\
(\mathbf{m m})\end{array}$ & $\begin{array}{l}\text { Length } \\
(\mathrm{mm})\end{array}$ & $\begin{array}{c}\text { Avg } \\
\text { length } \\
(\mathbf{m m})\end{array}$ \\
\hline $250 \mathrm{wt}$ & ZIRLO-H-3 & & 9.503 & 9.512 & & & & 23.496 & \\
\hline \multirow[t]{4}{*}{ ppm H } & ZIRLO-H-3 & & 9.500 & 9.508 & & & & 23.479 & \\
\hline & ZIRLO-H-3 & & 9.500 & 9.507 & & & & 23.505 & \\
\hline & ZIRLO-H-3 & & 9.500 & 9.512 & & & & & \\
\hline & ZIRLO-H-3 & & 9.498 & 9.507 & & & & & \\
\hline ZIRLO & ZIRLO-H-4 & 8.35 & 9.501 & 9.505 & 9.505 & 9.500 & 9.522 & 23.353 & 23.347 \\
\hline $250 \mathrm{wt}$ & ZIRLO-H-4 & & 9.503 & 9.506 & & & & 23.331 & \\
\hline \multirow[t]{4}{*}{ ppm H } & ZIRLO-H-4 & & 9.503 & 9.505 & & & & 23.363 & \\
\hline & ZIRLO-H-4 & & 9.501 & 9.505 & & & & 23.340 & \\
\hline & ZIRLO-H-4 & & 9.500 & 9.506 & & & & & \\
\hline & ZIRLO-H-4 & & 9.504 & 9.522 & & & & & \\
\hline ZIRLO & ZIRLO-H-5 & 8.35 & 9.500 & 9.505 & 9.504 & 9.500 & 9.509 & 23.455 & 23.441 \\
\hline $250 \mathrm{wt}$ & ZIRLO-H-5 & & 9.500 & 9.506 & & & & 23.427 & \\
\hline \multirow[t]{4}{*}{ ppm H } & ZIRLO-H-5 & & 9.503 & 9.507 & & & & 23.454 & \\
\hline & ZIRLO-H-5 & & 9.502 & 9.506 & & & & 23.426 & \\
\hline & ZIRLO-H-5 & & 9.502 & 9.507 & & & & & \\
\hline & ZIRLO-H-5 & & 9.502 & 9.509 & & & & & \\
\hline
\end{tabular}


Table B-2. Housing dimensions.

\begin{tabular}{|c|c|c|c|c|c|c|c|c|c|c|}
\hline $\begin{array}{c}\text { Housing } \\
\text { Part \# }\end{array}$ & $\begin{array}{c}\text { OD } \\
(\mathbf{m m})\end{array}$ & $\begin{array}{l}\text { ID } 1 \\
(\mathbf{m m})\end{array}$ & $\begin{array}{c}\text { ID } 2 \\
(\mathbf{m m})\end{array}$ & $\begin{array}{l}\text { ID } 3 \\
(\mathbf{m m})\end{array}$ & $\begin{array}{c}\text { ID } 4 \\
(\mathrm{~mm})\end{array}$ & $\begin{array}{c}\text { ID } 5 \\
(\mathbf{m m})\end{array}$ & $\begin{array}{c}\text { Max } \\
\text { ID } \\
(\mathbf{m m})\end{array}$ & $\begin{array}{c}\text { Min } \\
\text { ID } \\
(\mathbf{m m})\end{array}$ & $\begin{array}{c}\text { Avg } \\
\text { ID } \\
(\mathbf{m m})\end{array}$ & $\begin{array}{c}\text { ID Deviation } \\
(\mathrm{mm})\end{array}$ \\
\hline $16-01$ & 11.237 & 9.716 & 9.717 & 9.725 & 9.731 & 9.735 & 9.735 & 9.716 & 9.725 & $+0.005 /-0.004$ \\
\hline $16-02$ & 11.240 & 9.720 & 9.725 & 9.743 & 9.740 & 9.739 & 9.743 & 9.720 & 9.733 & $+0.005 /-0.007$ \\
\hline $16-03$ & 11.235 & 9.717 & 9.719 & 9.727 & 9.732 & 9.733 & 9.733 & 9.717 & 9.726 & $+0.004 /-0.004$ \\
\hline $16-04$ & 11.236 & 9.718 & 9.720 & 9.720 & 9.725 & 9.729 & 9.729 & 9.718 & 9.722 & $+0.003 /-0.002$ \\
\hline $16-05$ & 11.232 & 9.732 & 9.727 & 9.730 & 9.732 & 9.731 & 9.732 & 9.727 & 9.730 & $+0.001 /-0.002$ \\
\hline $16-06$ & 11.230 & 9.720 & 9.720 & 9.731 & 9.730 & 9.731 & 9.731 & 9.720 & 9.726 & $+0.002 /-0.003$ \\
\hline $16-07$ & 11.235 & 9.716 & 9.720 & 9.736 & 9.733 & 9.730 & 9.736 & 9.716 & 9.727 & $+0.005 /-0.006$ \\
\hline $16-08$ & 11.232 & 9.718 & 9.720 & 9.725 & 9.729 & 9.737 & 9.737 & 9.718 & 9.726 & $+0.006 /-0.004$ \\
\hline $16-09$ & 11.234 & 9.718 & 9.719 & 9.723 & 9.729 & 9.730 & 9.730 & 9.718 & 9.724 & $+0.003 /-0.003$ \\
\hline $16-10$ & 11.235 & 9.717 & 9.720 & 9.729 & 9.731 & 9.732 & 9.732 & 9.717 & 9.726 & $+0.003 /-0.004$ \\
\hline $16-12$ & 11.236 & 9.718 & 9.719 & 9.734 & 9.732 & 9.733 & 9.734 & 9.718 & 9.727 & $+0.003 /-0.005$ \\
\hline $16-13$ & 11.231 & 9.715 & 9.715 & 9.720 & 9.722 & 9.729 & 9.729 & 9.715 & 9.720 & $+0.004 /-0.003$ \\
\hline $16-14$ & 11.233 & 9.717 & 9.719 & 9.720 & 9.724 & 9.729 & 9.729 & 9.717 & 9.722 & $+0.004 /-0.002$ \\
\hline $16-15$ & 11.232 & 9.720 & 9.720 & 9.722 & 9.725 & 9.730 & 9.730 & 9.720 & 9.723 & $+0.003 /-0.002$ \\
\hline $16-16$ & 11.242 & 9.720 & 9.720 & 9.723 & 9.728 & 9.730 & 9.730 & 9.720 & 9.724 & $+0.003 /-0.002$ \\
\hline $16-17$ & 11.236 & 9.718 & 9.720 & 9.722 & 9.728 & 9.732 & 9.732 & 9.718 & 9.724 & $+0.004 /-0.003$ \\
\hline 16-18 & 11.235 & 9.720 & 9.720 & 9.722 & 9.726 & 9.730 & 9.730 & 9.720 & 9.724 & $+0.003 /-0.002$ \\
\hline
\end{tabular}





\section{APPENDIX C. ANSYS DESIGN REPORTS}





\section{APPENDIX C. ANSYS DESIGN REPORTS}

\section{FCF01:}

OUTPUT SUMMARY FILE

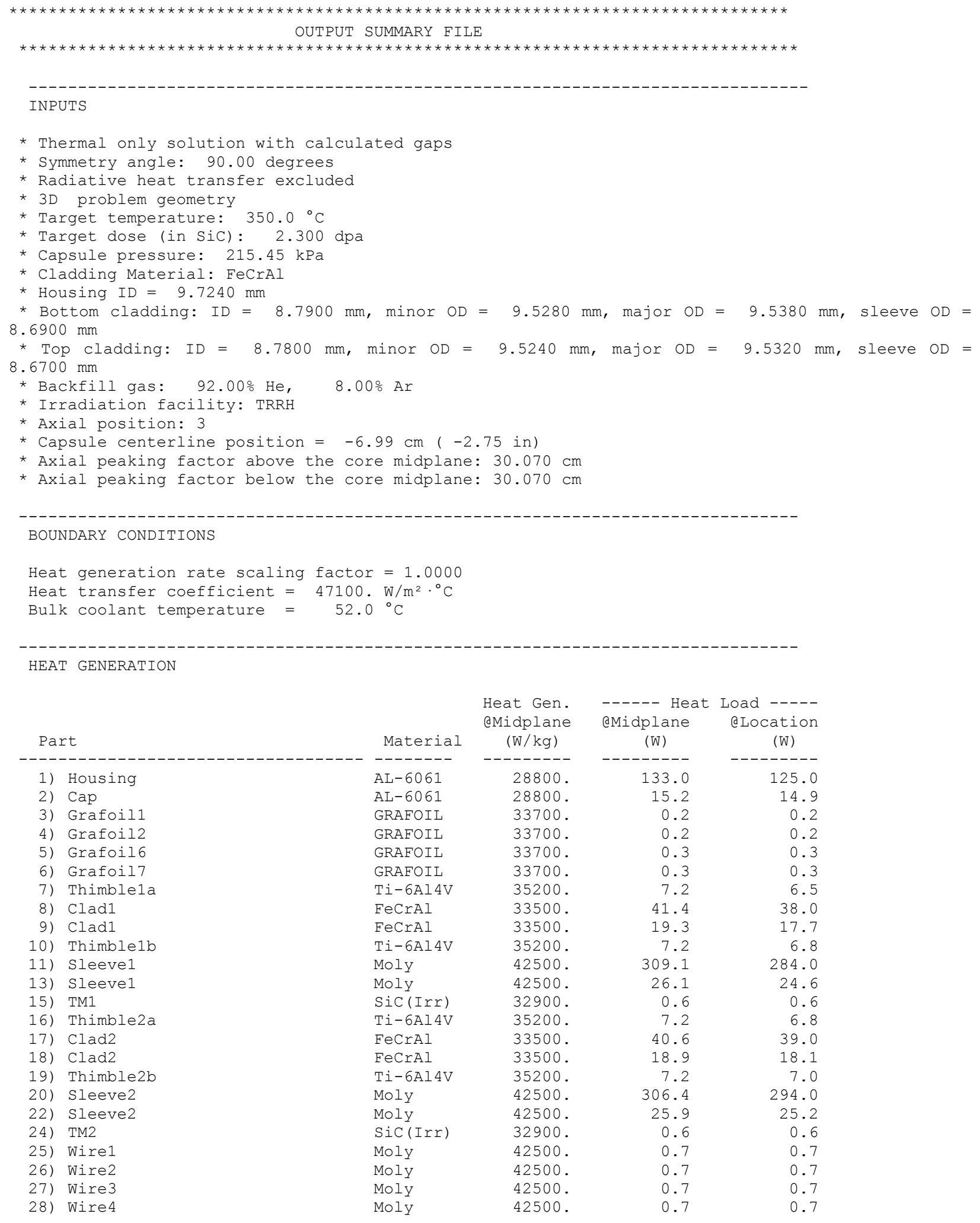




\begin{tabular}{|c|c|c|c|c|c|}
\hline 29) & Grafoil3 & GRAFOIL & 33700 . & 0.2 & 0.2 \\
\hline 30) & Grafoil4 & GRAFOIL & 33700 . & 0.2 & 0.2 \\
\hline 31$)$ & Grafoil5 & GRAFOIL & 33700 . & 0.2 & 0.2 \\
\hline 32) & Grafoil8 & GRAFOIL & 33700 . & 0.3 & 0.3 \\
\hline 33) & Grafoil9 & GRAFOIL & 33700 . & 0.3 & 0.3 \\
\hline 34) & Grafoillo & GRAFOIL & 33700 . & 0.3 & 0.3 \\
\hline & ------------------------- & -------- & -- & $\begin{array}{r}-------- \\
971.5\end{array}$ & $\begin{array}{r}------- \\
914.0\end{array}$ \\
\hline
\end{tabular}

CAPSULE TEMPERATURE SUMMARY

\begin{tabular}{|c|c|c|c|c|c|c|c|}
\hline \multicolumn{2}{|l|}{ Name } & Material & Tavg & Tmin & $\operatorname{Tmax}$ & T.025 & T. 975 \\
\hline & 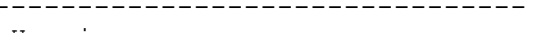 & -------- & ----- & ----- & ----- & ----- & ----- \\
\hline 1) & Housing & AL- 6061 & 63. & 54. & 78. & 54 . & 75 . \\
\hline 2) & Cap & AL- 6061 & 87 . & 85 . & 88 . & 86. & 88 . \\
\hline 3) & Grafoill & GRAFOIL & 116. & 109. & 123. & 115 & 117. \\
\hline 4) & Grafoil2 & GRAFOIL & 161. & 154 . & 169. & 159. & 162. \\
\hline 5) & Grafoil 6 & GRAFOIL & 525 & 515. & 531. & 517. & 529. \\
\hline 6) & Grafoil7 & GRAFOIL & 522 . & 514. & 526. & 516. & 526 . \\
\hline 7) & Thimblela & Ti-6Al4V & 373. & 288 . & 413. & 336. & 412 . \\
\hline 8) & Clad1 & FeCrAl & 324 . & 298. & 354 . & 303. & 347 . \\
\hline 9) & Clad1 & FeCrAl & 318. & 295. & 345 . & 298 . & 341. \\
\hline 10$)$ & Thimble1b & Ti-6Al4V & 497 . & 383. & 504 . & 470 . & 503. \\
\hline 11) & Sleeve1 & Moly & 444 & 399. & 489. & 405 . & 484 . \\
\hline 13) & Sleeve1 & Moly & 491 . & 486. & 494 . & 488. & 494. \\
\hline 15) & TM1 & SiC (Irr) & 447 & 383. & 490. & 404 . & 488 . \\
\hline 16) & Thimble2a & $\mathrm{Ti}-6 \mathrm{Al} 4 \mathrm{~V}$ & 500 & 368. & 509 . & 460 . & 509. \\
\hline 17) & $\mathrm{Clad} 2$ & FeCrAl & 347 . & 336. & 384. & 340 . & 359. \\
\hline 18) & Clad2 & FeCrAl & 341. & 332 . & 375 . & 334 . & 353. \\
\hline 19) & Thimble2b & Ti-6Al4V & 536. & 415 . & 544 . & 509 . & 544. \\
\hline 20$)$ & Sleeve2 & Moly & 507 . & 494. & 534. & 497. & 530. \\
\hline 22) & Sleeve2 & Moly & 536. & 531. & 538. & 533. & 537. \\
\hline 24) & TM2 & SiC (Irr) & 509 . & 496. & 535. & 499. & 534. \\
\hline 25$)$ & Wire1 & Moly & 439. & 425 . & 448 & 426. & 448 . \\
\hline 26$)$ & Wire2 & Moly & 534. & 522 . & 544. & 522 . & 544. \\
\hline 27) & Wire3 & Moly & 531. & 515. & 541. & 516. & 541. \\
\hline 28) & Wire 4 & Moly & 579. & 566. & 589. & 566. & 589. \\
\hline 29) & Grafoil3 & GRAFOIL & 203. & 193. & 213. & 199. & 206 . \\
\hline 30$)$ & Grafoil4 & GRAFOIL & 244 . & 228 . & 258 . & 232 . & 250. \\
\hline 31$)$ & Grafoil5 & GRAFOIL & 283. & 252 . & 305 . & 255 . & 295. \\
\hline 32$)$ & Grafoil8 & GRAFOIL & 520 . & 513. & 525 . & 514. & 525. \\
\hline 33) & Grafoil9 & GRAFOIL & 519. & 512 . & 525. & 513. & 524. \\
\hline 34) & Grafoil10 & GRAFOIL & 518. & 511. & 524 . & 512 . & 524. \\
\hline
\end{tabular}

PROPERTY SUMMARY AT THE AVERAGE PART TEMPERATURE

\begin{tabular}{|c|c|c|c|c|c|}
\hline Name & & Material & $\begin{array}{l}\text { Thermal } \\
\text { Cond. } \\
\left(\mathrm{W} / \mathrm{m} \cdot{ }^{\circ} \mathrm{C}\right)\end{array}$ & $\begin{array}{c}\text { Thermal } \\
\text { Exp. } \\
\text { Coeff. } \\
\left(\mu \mathrm{m} / \mathrm{m} \cdot{ }^{\circ} \mathrm{C}\right)\end{array}$ & $\begin{array}{l}\text { Emis } \\
\quad(---)\end{array}$ \\
\hline----- & ---------------------------- & -------- & --------- & --------- & --------- \\
\hline 1) & Housing & AL- 6061 & 166.992 & 24.21 & 0.050 \\
\hline 2) & Cap & $\mathrm{AL}-6061$ & 169.774 & 0.00 & 0.050 \\
\hline 3) & Grafoil1 & GRAFOIL & 38.000 & 1.00 & 0.500 \\
\hline 4) & Grafoil2 & GRAFOIL & 38.000 & 1.00 & 0.500 \\
\hline 5) & Grafoil 6 & GRAFOIL & 38.000 & 1.00 & 0.500 \\
\hline 6) & Grafoil 7 & GRAFOIL & 38.000 & 1.00 & 0.500 \\
\hline 7) & Thimblela & $\mathrm{Ti}-6 \mathrm{Al} 4 \mathrm{~V}$ & 14.044 & 10.00 & 0.385 \\
\hline 8) & Clad1 & FeCrAl & 15.717 & 11.30 & 0.143 \\
\hline 9) & Cladl & FeCrAl & 15.630 & 11.27 & 0.143 \\
\hline 10) & Thimblelb & $\mathrm{Ti}-6 \mathrm{Al} 4 \mathrm{~V}$ & 16.574 & 10.25 & 0.404 \\
\hline 11) & Sleevel & Moly & 121.314 & 5.15 & 0.072 \\
\hline 13) & Sleeve1 & Moly & 119.433 & 0.00 & 0.076 \\
\hline 15) & TM1 & $\operatorname{SiC}(\operatorname{Irr})$ & 8.679 & 3.65 & 0.900 \\
\hline 16) & Thimble2a & $\mathrm{Ti}-6 \mathrm{Al} 4 \mathrm{~V}$ & 16.629 & 10.25 & 0.404 \\
\hline 17) & Clad2 & FeCrAl & 16.073 & 11.39 & 0.143 \\
\hline 18) & Clad2 & FeCrAl & 15.981 & 11.36 & 0.143 \\
\hline 19) & Thimble2b & $\mathrm{Ti}-6 \mathrm{Al} 4 \mathrm{~V}$ & 17.268 & 10.33 & 0.416 \\
\hline 20) & Sleeve2 & Moly & 118.818 & 5.21 & 0.078 \\
\hline
\end{tabular}




$\begin{array}{llrrr}\text { 22) Sleeve2 } & \text { Moly } & 117.743 & 0.00 & 0.082 \\ \text { 24) TM2 } & \text { SiC(Irr) } & 8.630 & 3.79 & 0.900 \\ \text { 25) Wire1 } & \text { Moly } & 121.529 & 0.00 & 0.071 \\ \text { 26) Wire2 } & \text { Moly } & 117.777 & 0.00 & 0.081 \\ \text { 27) Wire3 } & \text { Moly } & 117.895 & 0.00 & 0.081 \\ \text { 28) Wire4 } & \text { Moly } & 116.437 & 0.00 & 0.087 \\ \text { 29) Grafoil3 } & \text { GRAFOIL } & 38.000 & 1.00 & 0.500 \\ \text { 30) Grafoil4 } & \text { GRAFOIL } & 38.000 & 1.00 & 0.500 \\ \text { 31) Grafoil5 } & \text { GRAFOIL } & 38.000 & 1.00 & 0.500 \\ \text { 32) Grafoil8 } & \text { GRAFOIL } & 38.000 & 1.00 & 0.500 \\ \text { 33) Grafoil9 } & \text { GRAFOIL } & 38.000 & 1.00 & 0.500 \\ \text { 34) Grafoil10 } & \text { GRAFOIL } & 38.000 & 1.00 & 0.500\end{array}$

STORED ENERGY SUMMARY AT THE AVERAGE PART TEMPERATURE

\begin{tabular}{|c|c|c|c|c|c|c|}
\hline \multicolumn{2}{|l|}{ Name } & Material & $\begin{array}{r}\text { Mass } \\
(\mathrm{g})\end{array}$ & $\begin{array}{l}\text { Tavg } \\
\left({ }^{\circ} \mathrm{C}\right)\end{array}$ & $\begin{array}{c}\text { Specific } \\
\text { Heat } \\
\left(\mathrm{J} / \mathrm{kg}^{\circ} \mathrm{C}\right)\end{array}$ & $\begin{array}{c}\text { Stored } \\
\text { Energy } \\
\text { (J) }\end{array}$ \\
\hline 1) & Housing & $\mathrm{AL}-6061$ & 4.618 & 63. & 887. & 175 \\
\hline 2) & Cap & $\mathrm{AL}-6061$ & 0.527 & 87. & 906. & 32 \\
\hline 3) & Grafoill & GRAFOIL & 0.006 & 116. & 700. & 0 \\
\hline 4) & Grafoil2 & GRAFOIL & 0.006 & 161. & 700. & 1 \\
\hline 5) & Grafoil 6 & GRAFOIL & 0.008 & 525. & 700. & \\
\hline 6) & Grafoil7 & GRAFOIL & 0.008 & 522. & 700. & 3 \\
\hline 7) & Thimblela & $\mathrm{Ti}-6 \mathrm{~A} 14 \mathrm{~V}$ & 0.205 & 373. & 718. & 52 \\
\hline 8) & Clad1 & FeCrAl & 1.235 & 324. & 603. & 227 \\
\hline 9) & Clad1 & FeCrAl & 0.577 & 318. & 601. & 103 \\
\hline 10) & Thimble1b & $\mathrm{Ti}-6 \mathrm{Al} 4 \mathrm{~V}$ & 0.205 & 497. & 769. & 75 \\
\hline 11) & Sleevel & Moly & 7.274 & 444. & 273. & 841 \\
\hline 13) & Sleevel & Moly & 0.615 & 491. & 275. & 80 \\
\hline 15) & TM1 & $\operatorname{SiC}(\operatorname{Irr})$ & 0.019 & 447. & 1093. & . \\
\hline 16) & Thimble2a & $\mathrm{Ti}-6 \mathrm{Al} 4 \mathrm{~V}$ & 0.205 & 500. & 770 . & 76 \\
\hline 17) & $\mathrm{Clad} 2$ & FeCrAl & 1.212 & 347. & 611. & 242 \\
\hline 18) & $\mathrm{Clad} 2$ & FeCrAl & 0.564 & 341. & 609. & 110 \\
\hline 19) & Thimble2b & $\mathrm{Ti}-6 \mathrm{Al} 4 \mathrm{~V}$ & 0.205 & 536. & 790. & 84 \\
\hline 20) & Sleeve2 & Moly & 7.209 & 507. & 275. & 965 \\
\hline 22) & Sleeve2 & Moly & 0.609 & 536. & 277. & 87 \\
\hline 24) & TM2 & $\operatorname{SiC}(\operatorname{Irr})$ & 0.019 & 509. & 1120 . & 1. \\
\hline 25) & Wire1 & Moly & 0.017 & 439. & 272 . & \\
\hline 26) & Wire2 & Moly & 0.017 & 534. & 277. & \\
\hline 27) & Wire3 & Moly & 0.017 & 531. & 276. & \\
\hline 28) & Wire4 & Moly & 0.017 & 579. & 279. & \\
\hline 29) & Grafoil3 & GRAFOIL & 0.006 & 203. & 700. & \\
\hline 30$)$ & Grafoil4 & GRAFOIL & 0.006 & 244. & 700. & \\
\hline 31) & Grafoil5 & GRAFOIL & 0.006 & 283. & 700. & \\
\hline 32) & Grafoil8 & GRAFOIL & 0.008 & 520. & 700. & \\
\hline 33) & Grafoilg & GRAFOIL & 0.008 & 519. & 700. & \\
\hline 34$)$ & Grafoil10 & GRAFOIL & 0.008 & 518. & 700. & \\
\hline & & & $\begin{array}{r}------- \\
25.442\end{array}$ & & & \\
\hline
\end{tabular}

CLAD TO HOUSING GAP REPORTS

\begin{tabular}{|c|c|c|c|c|}
\hline $\begin{array}{l}\text { ONTACT SUMMARY FOR CONTACT ID } \\
\text { Contact surface material: } \\
\text { Target surface material: } \\
\text { Interstitial gas: } \\
\text { Effective surface roughness: } \\
\text { Effective asperity slope: } \\
\text { Effective microhardness: }\end{array}$ & $\begin{array}{l}\text { 9: Cladl T } \\
\text { FeCrAl } \\
\text { AL- } 6061 \\
920 \mathrm{HE} 80 \\
2 . \overline{2} 63 \\
0.214 \\
1.220\end{array}$ & $\begin{array}{l}\text { To Housing } \\
\mu \mathrm{m} \\
\mathrm{rad} \\
\mathrm{GPa}\end{array}$ & ionless) & \\
\hline & & Average & Minimum & Maximum \\
\hline $\begin{array}{l}\text { Contact status } \\
\text { Contact temperature }\left({ }^{\circ} \mathrm{C}\right)\end{array}$ & & $\begin{array}{r}1.000 \\
316.581\end{array}$ & $\begin{array}{r}1.000 \\
294.578\end{array}$ & $\begin{array}{r}1.000 \\
340.780\end{array}$ \\
\hline
\end{tabular}




$\begin{array}{lrrr}\text { Target temperature }\left({ }^{\circ} \mathrm{C}\right) & 63.793 & 61.686 & 64.697 \\ \text { Geometric gas gap }(\mu \mathrm{m}) & 95.381 & 92.846 & 97.836 \\ \text { Contact pressure }(\mathrm{MPa}) & 0.000 & 0.000 & 0.000 \\ \text { Gap conduction heat flux }\left(\mathrm{kW} / \mathrm{m}^{2}\right) & 488.348 & 430.285 & 562.374 \\ \text { Radiation heat flux }\left(\mathrm{kW} / \mathrm{m}^{2}\right) & 0.000 & 0.000 & 0.000 \\ \text { Contact conduction heat flux }\left(\mathrm{kW} / \mathrm{m}^{2}\right) & 0.000 & 0.000 & 0.000 \\ \text { Total heat flux }\left(\mathrm{kW} / \mathrm{m}^{2}\right) & 488.348 & 430.285 & 562.374 \\ \text { Thermal contact conductance }\left(\mathrm{W} / \mathrm{m}^{2} \cdot \mathrm{C}\right) & 1930.269 & 1830.457 & 2047.934 \\ \sim \sim \sim \sim \sim & \\ \text { Effective gas gap }(\mu \mathrm{m}) & & & \\ \text { Contact thermal jump distance }(\mu \mathrm{m}) & 84.395 & 80.448 & 87.855 \\ \text { Target thermal jump distance }(\mu \mathrm{m}) & 1.285 & 1.222 & 1.351 \\ \text { Effective contact pressure }(\mathrm{MPa}) & 0.931 & 0.904 & 0.959 \\ \text { Pressure index } & 0.000 & 0.000 & 0.000 \\ \text { Gas thermal conductivity }\left(\mathrm{W} / \mathrm{m} \cdot{ }^{\circ} \mathrm{C}\right) & 19.925 & 19.876 & 19.969 \\ \text { Solid spot conductance }\left(\mathrm{W} / \mathrm{m}^{2} \cdot \mathrm{C}\right) & 0.167 & 0.164 & 0.170 \\ \text { Gas gap conductance }\left(\mathrm{W} / \mathrm{m}^{2} \cdot \mathrm{C}\right) & 0.000 & 0.000 & 0.000 \\ & 1930.380 & 1830.182 & 2048.048\end{array}$

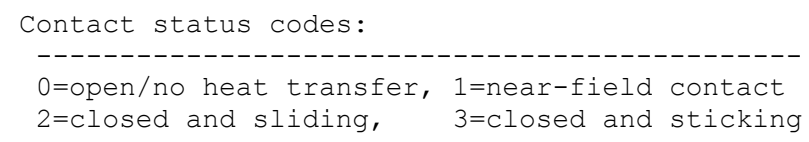




\section{FCF02:}

OUTPUT SUMMARY FILE

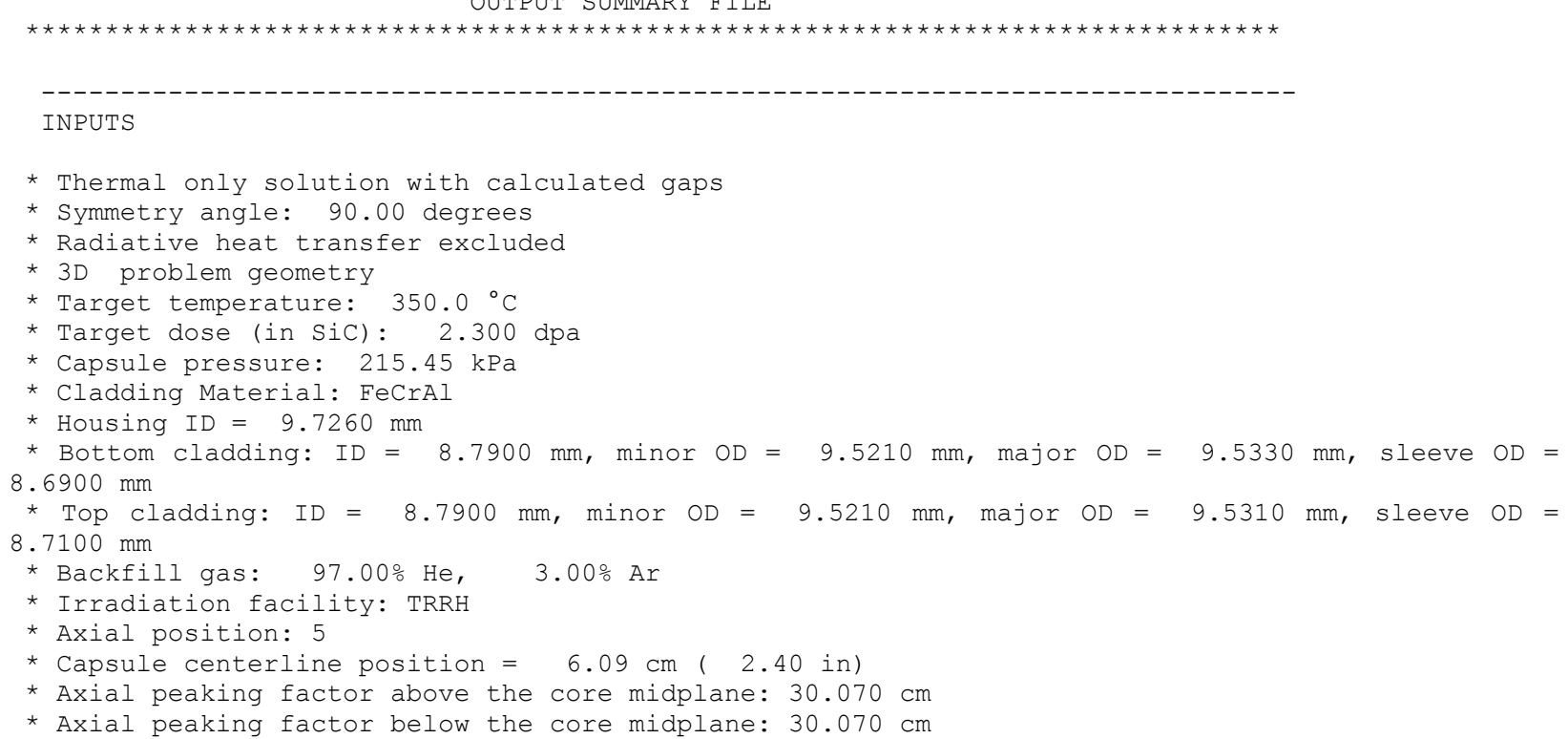

$\begin{array}{rr}\begin{array}{rr}\text { aMidplane } \\ \text { (W) }\end{array} & \begin{array}{r}\text { Load } \\ \text { @Location }\end{array} \\ 132.9 & 127.5 \\ 15.2 & 13.9 \\ 0.2 & 0.2 \\ 0.2 & 0.2 \\ 0.3 & 0.3 \\ 0.3 & 0.3 \\ 7.2 & 7.1 \\ 40.6 & 39.8 \\ 18.8 & 18.4 \\ 7.2 & 7.0 \\ 309.1 & 302.6 \\ 26.1 & 25.2 \\ 0.6 & 0.6 \\ 7.2 & 6.9 \\ 40.6 & 38.5 \\ 18.7 & 17.7 \\ 7.2 & 6.7 \\ 311.9 & 295.3 \\ 26.4 & 24.4 \\ 0.6 & 0.6 \\ 0.7 & 0.7 \\ 0.7 & 0.7 \\ 0.7 & 0.7 \\ 0.7 & 0.7 \\ 0.2 & 0.2 \\ 0.2 & 0.2 \\ 0.2 & 0.2 \\ & \end{array}$




\begin{tabular}{|c|c|c|c|c|c|}
\hline 32) & Grafoil8 & GRAFOIL & 33700 . & 0.3 & 0.3 \\
\hline 33) & Grafoil9 & GRAFOIL & 33700 . & 0.3 & 0.3 \\
\hline 34) & Grafoillo & GRAFOIL & 33700 . & 0.3 & 0.3 \\
\hline & & -----1 & & & \\
\hline
\end{tabular}

CAPSULE TEMPERATURE SUMMARY

\begin{tabular}{|c|c|c|c|c|c|c|c|}
\hline Name & & Material & Tavg & Tmin & $\operatorname{Tmax}$ & T. 025 & T. 975 \\
\hline 1) & Housing & $\mathrm{AL}-6061$ & 63. & 54. & 80 & 54 & 77. \\
\hline 2) & Cap & $\mathrm{AL}-6061$ & 82. & 80. & 83. & 80. & 83. \\
\hline 3) & Grafoill & GRAFOIL & 117. & 109. & 125 & 116. & 118. \\
\hline 4) & Grafoil2 & GRAFOIL & 161. & 154. & 170. & 160. & 163. \\
\hline 5) & Grafoil 6 & GRAFOIL & 455. & 447. & 460 & 449 . & 459. \\
\hline 6) & Grafoil7 & GRAFOIL & 453. & 446. & 456 & 447. & 456. \\
\hline 7) & Thimblela & $\mathrm{Ti}-6 \mathrm{Al} 4 \mathrm{~V}$ & 376. & 287. & 417. & 336. & 415. \\
\hline 8) & Clad1 & FeCrAl & 319. & 296. & 343. & 301. & 336. \\
\hline 9) & Cladl & FeCrAl & 313. & 293. & 334. & 296. & 330. \\
\hline 10) & Thimblelb & Ti-6Al4V & 476. & 366. & 486. & 447. & 485. \\
\hline 11) & Sleeve1 & Moly & 442 . & 402. & 476. & 408. & 473. \\
\hline 13) & Sleevel & Moly & 477. & 473. & 479. & 475. & 479. \\
\hline 15) & TM1 & $\operatorname{SiC}(\operatorname{Ir} r)$ & 444. & 385. & 477 . & 406. & 476. \\
\hline 16) & Thimble2a & Ti-6Al4V & 457. & 344. & 469. & 426. & 466. \\
\hline 17) & $\mathrm{Clad} 2$ & FeCrAl & 331. & 321. & 366. & 326. & 340. \\
\hline 18) & $\mathrm{Clad} 2$ & FeCrAl & 325. & 318. & 356 . & 320. & 333. \\
\hline 19) & Thimble2b & Ti-6Al4V & 465. & 361. & 472 . & 442 . & 471. \\
\hline 20) & Sleeve2 & Moly & 443. & 435. & 462. & 436. & 458. \\
\hline 22) & Sleeve2 & Moly & 463. & 459. & 466. & 461. & 465 . \\
\hline 24) & TM2 & $\operatorname{SiC}(\operatorname{Ir} r)$ & 445. & 439. & 463. & 439. & 462. \\
\hline 25) & Wire1 & Moly & 443. & 428. & 453. & 429. & 453. \\
\hline 26) & Wire2 & Moly & 518. & 505. & 528. & 505. & 528. \\
\hline 27) & Wire3 & Moly & 480. & 464. & 490. & 465. & 490. \\
\hline 28) & Wire4 & Moly & 503. & 491. & 512. & 491. & 512. \\
\hline 29) & Grafoil3 & GRAFOIL & 204. & 193. & 214 & 199. & 207. \\
\hline 30$)$ & Grafoil4 & GRAFOIL & 244. & 227. & 259 . & 232 . & 251. \\
\hline 31) & Grafoil5 & GRAFOIL & 283. & 251. & 307 . & 254. & 296. \\
\hline 32) & Grafoil8 & GRAFOIL & 451. & 444. & 456. & 446 . & 456. \\
\hline 33) & Grafoilg & GRAFOIL & 450. & 444. & 455. & 445 . & 455. \\
\hline 34) & Grafoillo & GRAFOIL & 449. & 443. & 455. & 444. & 455. \\
\hline
\end{tabular}

PROPERTY SUMMARY AT THE AVERAGE PART TEMPERATURE

\begin{tabular}{|c|c|c|c|c|c|}
\hline \multicolumn{2}{|l|}{ Name } & \multirow{2}{*}{$\begin{array}{l}\text { Material } \\
---\end{array}$} & $\begin{array}{l}\text { Thermal } \\
\text { Cond. } \\
\left(\mathrm{W} / \mathrm{m} \cdot{ }^{\circ} \mathrm{C}\right)\end{array}$ & $\begin{array}{l}\text { Thermal } \\
\text { Exp. } \\
\text { Coeff. } \\
\left(\mu \mathrm{m} / \mathrm{m} \cdot{ }^{\circ} \mathrm{C}\right)\end{array}$ & $\begin{array}{l}\text { Emis } \\
\quad(---)\end{array}$ \\
\hline & & & -------- & -------- & ------ \\
\hline 1) & Housing & $A L-6061$ & 167.037 & 24.21 & 0.050 \\
\hline 2) & Cap & $\mathrm{AL}-6061$ & 169.192 & 0.00 & 0.050 \\
\hline 3) & Grafoill & GRAFOIL & 38.000 & 1.00 & 0.500 \\
\hline 4) & Grafoil2 & GRAFOIL & 38.000 & 1.00 & 0.500 \\
\hline 5) & Grafoil 6 & GRAFOIL & 38.000 & 1.00 & 0.500 \\
\hline 6) & Grafoil7 & GRAFOIL & 38.000 & 1.00 & 0.500 \\
\hline 7) & Thimblela & Ti-6Al4V & 14.089 & 10.01 & 0.386 \\
\hline 8) & Clad1 & FeCrAl & 15.638 & 11.28 & 0.143 \\
\hline 9) & Clad1 & FeCrAl & 15.547 & 11.25 & 0.143 \\
\hline 10) & Thimblelb & $\mathrm{Ti}-6 \mathrm{Al} 4 \mathrm{~V}$ & 16.164 & 10.20 & 0.404 \\
\hline 11) & Sleeve1 & Moly & 121.415 & 5.15 & 0.071 \\
\hline 13) & Sleevel & Moly & 119.991 & 0.00 & 0.075 \\
\hline 15) & TM1 & $\operatorname{SiC}(\operatorname{Ir} r)$ & 8.681 & 3.64 & 0.900 \\
\hline 16) & Thimble $2 \mathrm{a}$ & $\mathrm{Ti}-6 \mathrm{Al} 4 \mathrm{~V}$ & 15.756 & 10.16 & 0.402 \\
\hline 17) & $\mathrm{Clad2}$ & FeCrAl & 15.827 & 11.32 & 0.143 \\
\hline 18) & $\mathrm{Clad} 2$ & FeCrAl & 15.732 & 11.30 & 0.143 \\
\hline 19) & Thimble2b & $\mathrm{Ti}-6 \mathrm{Al} 4 \mathrm{~V}$ & 15.930 & 10.18 & 0.403 \\
\hline 20) & Sleeve2 & Moly & 121.375 & 5.15 & 0.071 \\
\hline 22) & Sleeve2 & Moly & 120.541 & 0.00 & 0.074 \\
\hline 24) & TM2 & $\operatorname{SiC}(\operatorname{Irr})$ & 8.680 & 3.65 & 0.900 \\
\hline 25) & Wire1 & Moly & 121.373 & 0.00 & 0.071 \\
\hline
\end{tabular}




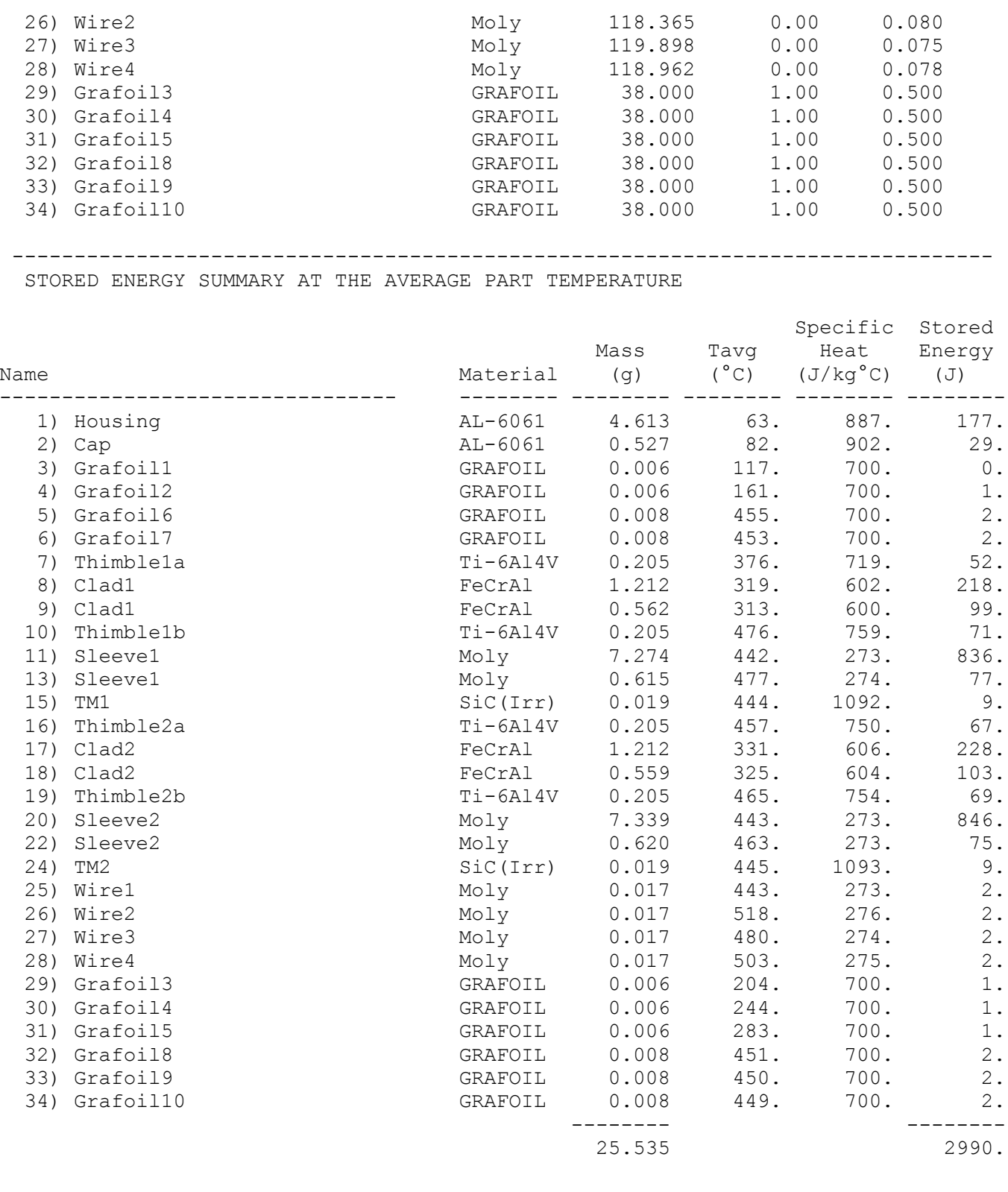

CLAD TO HOUSING GAP REPORTS

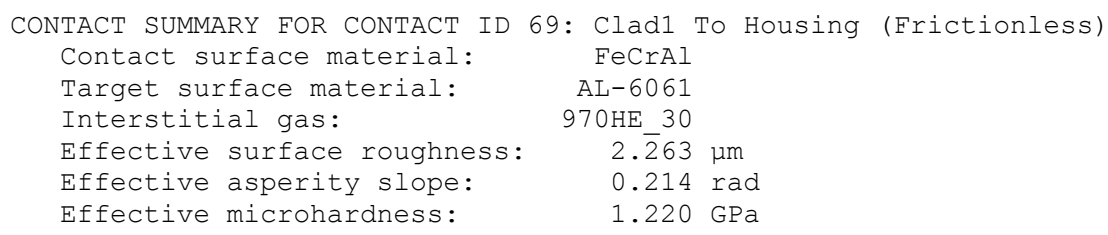


Gap conduction heat flux $\left(\mathrm{kW} / \mathrm{m}^{2}\right)$

Radiation heat flux $\left(\mathrm{kW} / \mathrm{m}^{2}\right)$

Contact conduction heat flux $\left(\mathrm{kW} / \mathrm{m}^{2}\right)$

Total heat flux $\left(\mathrm{kW} / \mathrm{m}^{2}\right)$

Thermal contact conductance $\left(W / \mathrm{m}^{2} \cdot \mathrm{C}\right)$

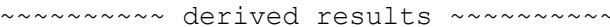

Effective gas gap ( $\mathrm{m}$ )

Contact thermal jump distance ( $\mu \mathrm{m})$

Target thermal jump distance ( $\mu m$ )

Effective contact pressure (MPa)

Pressure index

Gas thermal conductivity $\left(\mathrm{W} / \mathrm{m} \cdot{ }^{\circ} \mathrm{C}\right)$

Solid spot conductance $\left(\mathrm{W} / \mathrm{m}^{2} \cdot \mathrm{C}\right)$

Gas gap conductance $\left(W / \mathrm{m}^{2} \cdot \mathrm{C}\right)$
510.919

0.000

0.000

510.919

2068.551

88.783

1.553

1.119

0.000

19.936

0.189

0.000

2068.806
458.427

0.000

0.000

458.427

1966.546

84.680

1. 488

1.091

0.000

19.898

0.186

0.000

1966.429
573.557

0.000

0.000

573.557

2182.522

92.510

1.615

1.143

0.000

19.973

0.192

0.000

2183.402

Contact status codes:

$0=$ open/no heat transfer, 1 =near-field contact

2=closed and sliding, $\quad 3=$ closed and sticking

CONTACT SUMMARY FOR CONTACT ID 71: Clad2 TO Housing (Frictionless)

Contact surface material: FeCrAl

Target surface material: AL-6061

Interstitial gas: $\quad 970 \mathrm{HE} 30$

Effective surface roughness: $2 . \overline{2} 63 \mu \mathrm{m}$

Effective asperity slope: $0.214 \mathrm{rad}$

Effective microhardness: $\quad 1.220 \mathrm{GPa}$

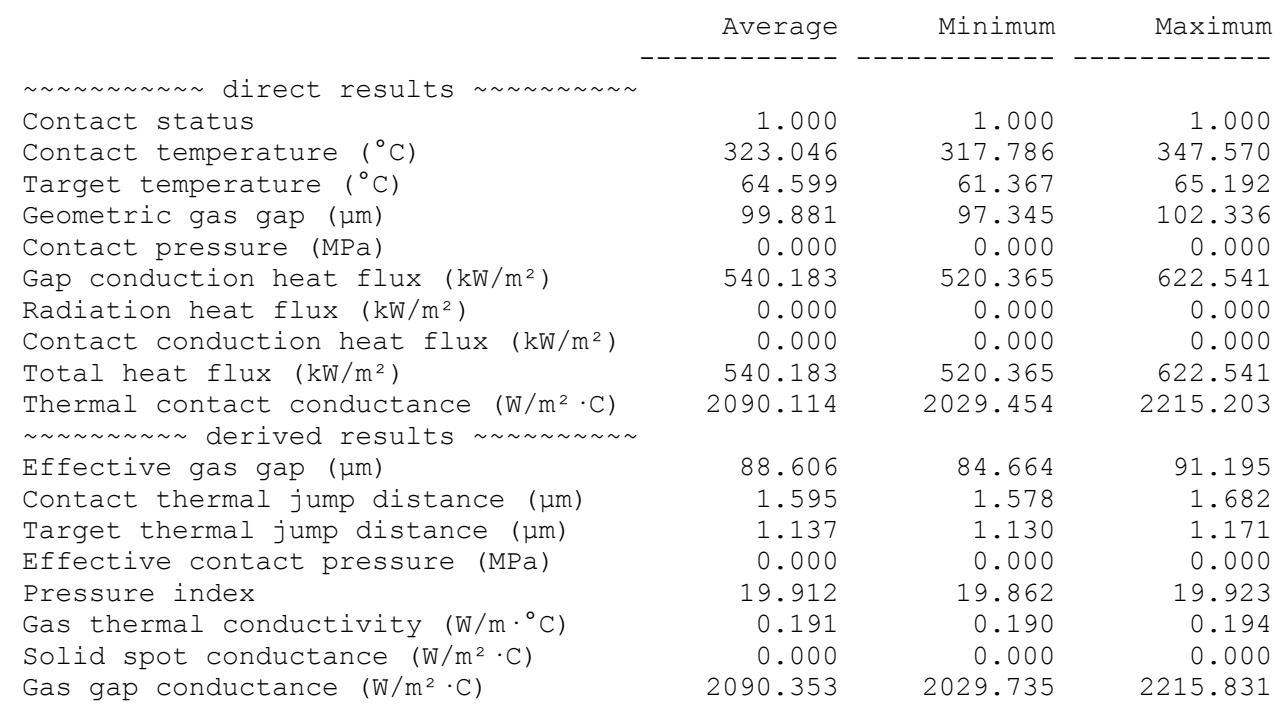

Contact status codes:

$0=$ open/no heat transfer, 1 =near-field contact

$2=$ closed and sliding, $3=$ closed and sticking 


\section{FCF03:}

OUTPUT SUMMARY FILE

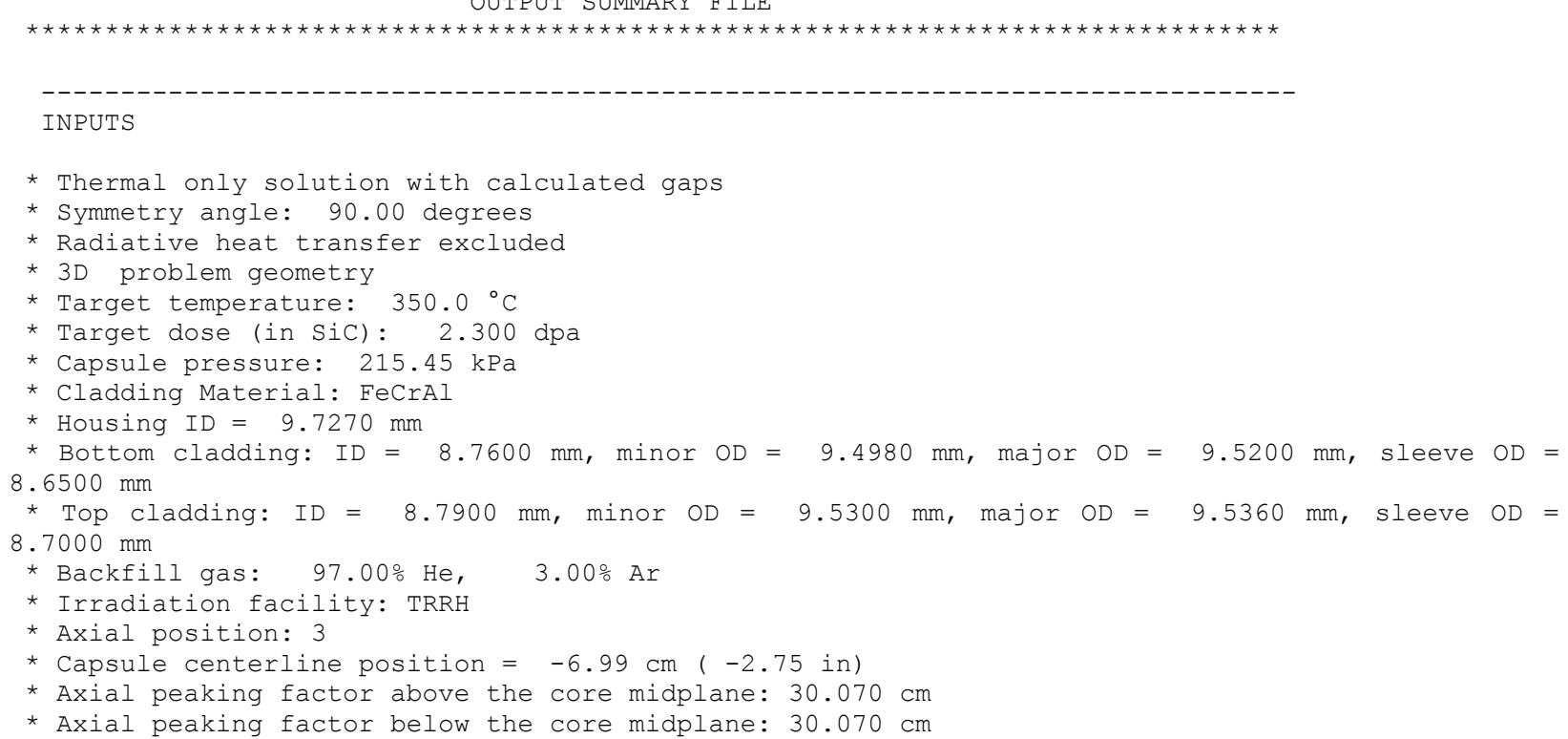

$\begin{array}{ll}\text { Part } \\ \text { 1) } & \text { Housing } \\ \text { 2) } & \text { Cap } \\ \text { 3) } & \text { Grafoil1 } \\ \text { 4) } & \text { Grafoil2 } \\ \text { 5) } & \text { Grafoil6 } \\ \text { 6) } & \text { Grafoil7 } \\ \text { 7) } & \text { Thimblela } \\ \text { 8) } & \text { Clad1 } \\ \text { 9) } & \text { Clad1 } \\ \text { 10) } & \text { Thimble1b } \\ \text { 11) } & \text { Sleeve1 } \\ \text { 13) } & \text { Sleeve1 } \\ \text { 15) } & \text { TM1 } \\ \text { 16) } & \text { Thimble2a } \\ \text { 17) } & \text { Clad2 } \\ \text { 18) } & \text { Clad2 } \\ \text { 19) } & \text { Thimble2b } \\ \text { 20) } & \text { Sleeve2 } \\ \text { 22) } & \text { Sleeve2 } \\ \text { 24) } & \text { TM2 } \\ \text { 25) } & \text { Wire1 } \\ \text { 26) } & \text { Wire2 } \\ \text { 27) } & \text { Wire3 } \\ \text { 28) } & \text { Wire4 } \\ \text { 29) } & \text { Grafoil3 } \\ \text { 30) } & \text { Grafoil4 } \\ \text { 31) } & \text { Grafoil5 }\end{array}$

$\begin{array}{lr}\text { Material } & (\mathrm{W} / \mathrm{kg}) \\ ------ & ---\cdot- \\ \text { AL-6061 } & 28800 . \\ \text { AL-6061 } & 28800 . \\ \text { GRAFOIL } & 33700 . \\ \text { GRAFOIL } & 33700 . \\ \text { GRAFOIL } & 33700 . \\ \text { GRAFOIL } & 33700 . \\ \text { Ti-6Al4V } & 35200 . \\ \text { FeCrAl } & 33500 . \\ \text { FeCrAl } & 33500 . \\ \text { Ti-6Al4V } & 35200 . \\ \text { Moly } & 42500 . \\ \text { Moly } & 42500 . \\ \text { SiC(Irr) } & 32900 . \\ \text { Ti-6Al4V } & 35200 . \\ \text { FeCrAl } & 33500 . \\ \text { FeCrAl } & 33500 . \\ \text { Ti-6Al4V } & 35200 . \\ \text { Moly } & 42500 . \\ \text { Moly } & 42500 . \\ \text { SiC(Irr) } & 32900 . \\ \text { Moly } & 42500 . \\ \text { Moly } & 42500 . \\ \text { Moly } & 42500 . \\ \text { Moly } & 42500 . \\ \text { GRAFOIL } & 33700 . \\ \text { GRAFOIL } & 33700 . \\ \text { GRAFOIL } & 33700 . \\ & \end{array}$

$\begin{array}{rr}\begin{array}{r}\text { aMidplane } \\ \text { (W) }\end{array} & \begin{array}{r}\text { Load } \\ \text { QLocation }\end{array} \\ 132.8 & 124.8 \\ 15.2 & 14.9 \\ 0.2 & 0.2 \\ 0.2 & 0.2 \\ 0.3 & 0.3 \\ 0.3 & 0.3 \\ 7.2 & 6.5 \\ 40.6 & 37.3 \\ 17.3 & 15.9 \\ 7.2 & 6.8 \\ 303.6 & 278.9 \\ 25.6 & 24.1 \\ 0.6 & 0.6 \\ 7.2 & 6.8 \\ 42.9 & 41.2 \\ 19.3 & 18.5 \\ 7.2 & 7.0 \\ 310.5 & 298.0 \\ 26.2 & 25.6 \\ 0.6 & 0.6 \\ 0.7 & 0.7 \\ 0.7 & 0.7 \\ 0.7 & 0.7 \\ 0.7 & 0.7 \\ 0.2 & 0.2 \\ 0.2 & 0.2 \\ 0.2 & 0.2\end{array}$




\begin{tabular}{|c|c|c|c|c|c|}
\hline 32) & Grafoil8 & GRAFOIL & 33700 . & 0.3 & 0.3 \\
\hline 33) & Grafoil9 & GRAFOIL & 33700 . & 0.3 & 0.3 \\
\hline 34) & Grafoillo & GRAFOIL & 33700 . & 0.3 & 0.3 \\
\hline & & $-x$ & & & \\
\hline
\end{tabular}

CAPSULE TEMPERATURE SUMMARY

\begin{tabular}{|c|c|c|c|c|c|c|c|}
\hline \multicolumn{2}{|l|}{ Name } & Material & Tavg & Tmin & Tmax & T.025 & T.975 \\
\hline & Housing & $\begin{array}{l}-------- \\
A T-6061\end{array}$ & $\begin{array}{c}----- \\
63\end{array}$ & ----- & ----- & $\begin{array}{c}----- \\
54\end{array}$ & $\begin{array}{c}----- \\
77\end{array}$ \\
\hline $\begin{array}{l}\text { 1) } \\
\text { 2) }\end{array}$ & $\begin{array}{l}\text { Housing } \\
\text { Cap }\end{array}$ & $\begin{array}{l}\mathrm{AL}-6061 \\
\mathrm{AL}-6061\end{array}$ & $\begin{array}{l}63 . \\
84 .\end{array}$ & $\begin{array}{l}54 . \\
82 .\end{array}$ & $\begin{array}{l}80 . \\
85 .\end{array}$ & $\begin{array}{l}54 . \\
82 .\end{array}$ & $\begin{array}{l}77 . \\
85 .\end{array}$ \\
\hline 3) & Grafoill & GRAFOIL & 118. & 110. & 126. & 117. & 119. \\
\hline 4) & Grafoil2 & GRAFOIL & 164. & 156. & 172. & 162. & 165. \\
\hline 5) & Grafoil6 & GRAFOIL & 447. & 438. & 451. & 440 . & 450. \\
\hline 6) & Grafoil7 & GRAFOIL & 444. & 437. & 448. & 439. & 448. \\
\hline 7) & Thimblela & $\mathrm{Ti}-6 \mathrm{Al} 4 \mathrm{~V}$ & 385. & 291. & 429. & 343. & 427. \\
\hline 8) & Clad1 & FeCrAl & 316. & 292. & 340 . & 296. & 334. \\
\hline 9) & Clad1 & FeCrAl & 311. & 289. & 332. & 291. & 329. \\
\hline 10) & Thimblelb & Ti-6Al4V & 484. & 371. & 499. & 451. & 499. \\
\hline 11) & Sleevel & Moly & 459. & 414. & 492. & 420 . & 489. \\
\hline 13) & Sleevel & Moly & 492. & 489. & 493. & 491. & 493. \\
\hline 15) & TM1 & $\operatorname{SiC}(\operatorname{Irr})$ & 461. & 396. & 493. & 419. & 492. \\
\hline 16) & Thimble2a & $\mathrm{Ti}-6 \mathrm{Al} 4 \mathrm{~V}$ & 448. & 342. & 465. & 421. & 462. \\
\hline 17) & $\mathrm{Clad2}$ & FeCrAl & 332. & 321. & 364. & 326. & 343. \\
\hline 18) & $\mathrm{Clad} 2$ & FeCrAl & 325. & 317. & 353. & 320. & 336. \\
\hline 19) & Thimble2b & Ti-6Al4V & 455. & 357. & 461. & 433. & 461. \\
\hline 20) & Sleeve2 & Moly & 427. & 418. & 451. & 419. & 447. \\
\hline 22) & Sleeve2 & Moly & 453. & 447. & 455. & 449. & 455. \\
\hline 24) & TM2 & $\operatorname{SiC}(\operatorname{Irr})$ & 430. & 422. & 452 . & 422 . & 450. \\
\hline 25) & Wire1 & Moly & 450. & 436. & 459. & 437. & 459. \\
\hline 26) & Wire2 & Moly & 531. & 518. & 540. & 519. & 540. \\
\hline 27) & Wire3 & Moly & 462. & 446. & 472 . & 447 . & 472. \\
\hline 28) & Wire4 & Moly & 495. & 482 . & 504. & 482. & 504. \\
\hline 29) & Grafoil3 & GRAFOIL & 207. & 196. & 218. & 202 . & 211. \\
\hline 30$)$ & Grafoil4 & GRAFOIL & 249. & 231. & 264. & 236. & 256. \\
\hline 31) & Grafoil5 & GRAFOIL & 289. & 256. & 313. & 259. & 302. \\
\hline 32) & Grafoil8 & GRAFOIL & 443. & 436. & 447. & 437. & 447. \\
\hline 33) & Grafoil9 & GRAFOIL & 442 . & 435. & 447. & 436. & 446. \\
\hline 34) & Grafoillo & GRAFOIL & 441. & 435. & 446. & 436. & 446. \\
\hline
\end{tabular}

PROPERTY SUMMARY AT THE AVERAGE PART TEMPERATURE

\begin{tabular}{|c|c|c|c|c|c|}
\hline \multicolumn{2}{|l|}{ Name } & \multirow{2}{*}{ Material } & $\begin{array}{l}\text { Thermal } \\
\text { Cond. } \\
\left(\mathrm{W} / \mathrm{m} \cdot{ }^{\circ} \mathrm{C}\right)\end{array}$ & $\begin{array}{l}\text { Thermal } \\
\text { Exp. } \\
\text { Coeff. } \\
\left(\mu \mathrm{m} / \mathrm{m} \cdot{ }^{\circ} \mathrm{C}\right)\end{array}$ & $\begin{array}{l}\text { Emis } \\
(---)\end{array}$ \\
\hline & -- & & --------- & --------- & -------- \\
\hline 1) & Housing & $\mathrm{AL}-6061$ & 167.002 & 24.21 & 0.050 \\
\hline 2) & Cap & $A L-6061$ & 169.424 & 0.00 & 0.050 \\
\hline 3) & Grafoill & GRAFOIL & 38.000 & 1.00 & 0.500 \\
\hline 4) & Grafoil2 & GRAFOIL & 38.000 & 1.00 & 0.500 \\
\hline 5) & Grafoil 6 & GRAFOIL & 38.000 & 1.00 & 0.500 \\
\hline 6) & Grafoil7 & GRAFOIL & 38.000 & 1.00 & 0.500 \\
\hline 7) & Thimblela & Ti-6Al4V & 14.277 & 10.02 & 0.389 \\
\hline 8) & Cladl & FeCrAl & 15.596 & 11.26 & 0.143 \\
\hline 9) & Cladl & FeCrAl & 15.515 & 11.24 & 0.143 \\
\hline 10) & Thimble1b & $\mathrm{Ti}-6 \mathrm{Al} 4 \mathrm{~V}$ & 16.337 & 10.22 & 0.404 \\
\hline 11) & Sleeve1 & Moly & 120.709 & 5.16 & 0.073 \\
\hline 13) & Sleevel & Moly & 119.390 & 0.00 & 0.077 \\
\hline 15) & TM1 & $\operatorname{SiC}(\operatorname{Irr})$ & 8.667 & 3.68 & 0.900 \\
\hline 16) & Thimble $2 \mathrm{a}$ & Ti-6Al4V & 15.562 & 10.14 & 0.400 \\
\hline 17) & $\mathrm{Clad} 2$ & FeCrAl & 15.835 & 11.33 & 0.143 \\
\hline 18) & $\mathrm{Clad} 2$ & FeCrAl & 15.733 & 11.30 & 0.143 \\
\hline 19) & Thimble2b & Ti-6Al4V & 15.717 & 10.16 & 0.401 \\
\hline 20) & Sleeve2 & Moly & 121.997 & 5.14 & 0.070 \\
\hline 22) & Sleeve2 & Moly & 120.976 & 0.00 & 0.072 \\
\hline 24) & TM2 & $\operatorname{SiC}(\operatorname{Irr})$ & 8.693 & 3.61 & 0.900 \\
\hline 25) & Wire1 & Moly & 121.087 & 0.00 & 0.072 \\
\hline
\end{tabular}




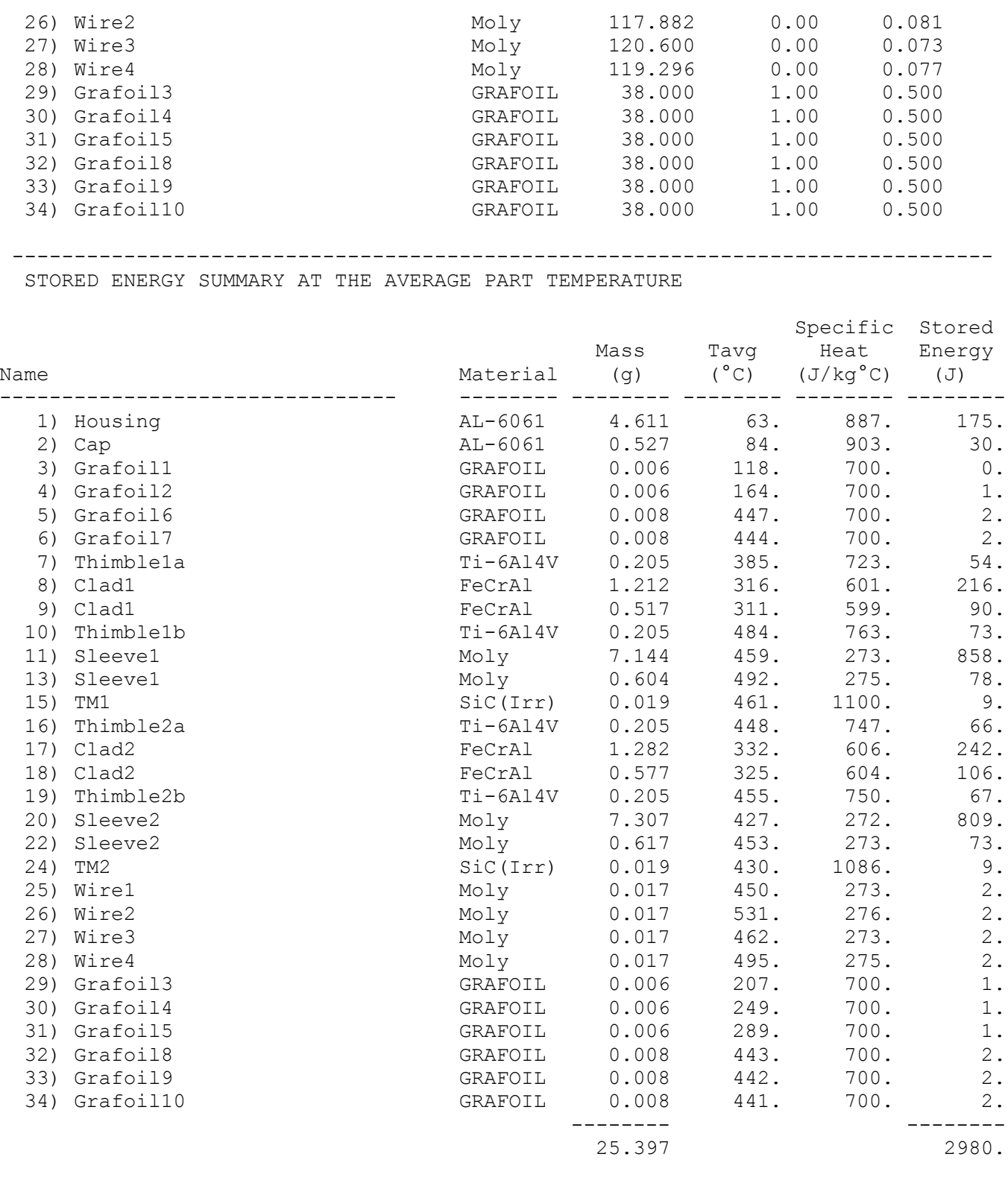

CLAD TO HOUSING GAP REPORTS

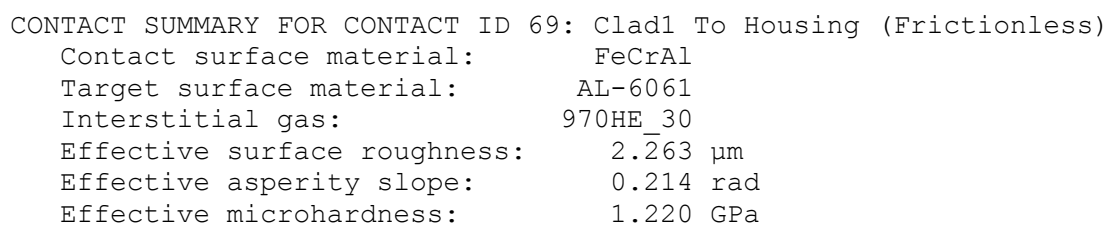


Gap conduction heat flux $\left(\mathrm{kW} / \mathrm{m}^{2}\right)$

Radiation heat flux $\left(\mathrm{kW} / \mathrm{m}^{2}\right)$

Contact conduction heat flux $\left(\mathrm{kW} / \mathrm{m}^{2}\right)$

Total heat flux $\left(\mathrm{kW} / \mathrm{m}^{2}\right)$

Thermal contact conductance $\left(\mathrm{W} / \mathrm{m}^{2} \cdot \mathrm{C}\right)$

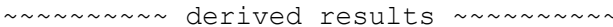

Effective gas gap ( $\mathrm{m}$ )

Contact thermal jump distance ( $\mu \mathrm{m})$

Target thermal jump distance ( $\mu m$ )

Effective contact pressure (MPa)

Pressure index

Gas thermal conductivity $\left(\mathrm{W} / \mathrm{m} \cdot{ }^{\circ} \mathrm{C}\right)$

Solid spot conductance $\left(\mathrm{W} / \mathrm{m}^{2} \cdot \mathrm{C}\right)$

Gas gap conductance $\left(W / \mathrm{m}^{2} \cdot \mathrm{C}\right)$
461.215

0.000

0.000

461.215

1871.926

98.262

1.545

1.114

0.000

19.939

0.189

0.000

1872.260
407.121

0.000

0.000

407.121

1744.072

91.874

1.473

1.084

0.000

19.899

0.186

0.000

1744.204
520.913

0.000

0.000

520.913

2009.509

104.448

1.612

1. 141

0.000

19.980

0.191

0.000

Contact status codes:

$0=$ open/no heat transfer, 1 =near-field contact

2=closed and sliding, $3=$ closed and sticking

CONTACT SUMMARY FOR CONTACT ID 71: Clad2 TO Housing (Frictionless)

Contact surface material: FeCrAl

Target surface material: AL-6061

Interstitial gas: $\quad 970 \mathrm{HE} 30$

Effective surface roughness: $2 . \overline{2} 63 \mu \mathrm{m}$

Effective asperity slope: $0.214 \mathrm{rad}$

Effective microhardness: $\quad 1.220 \mathrm{GPa}$

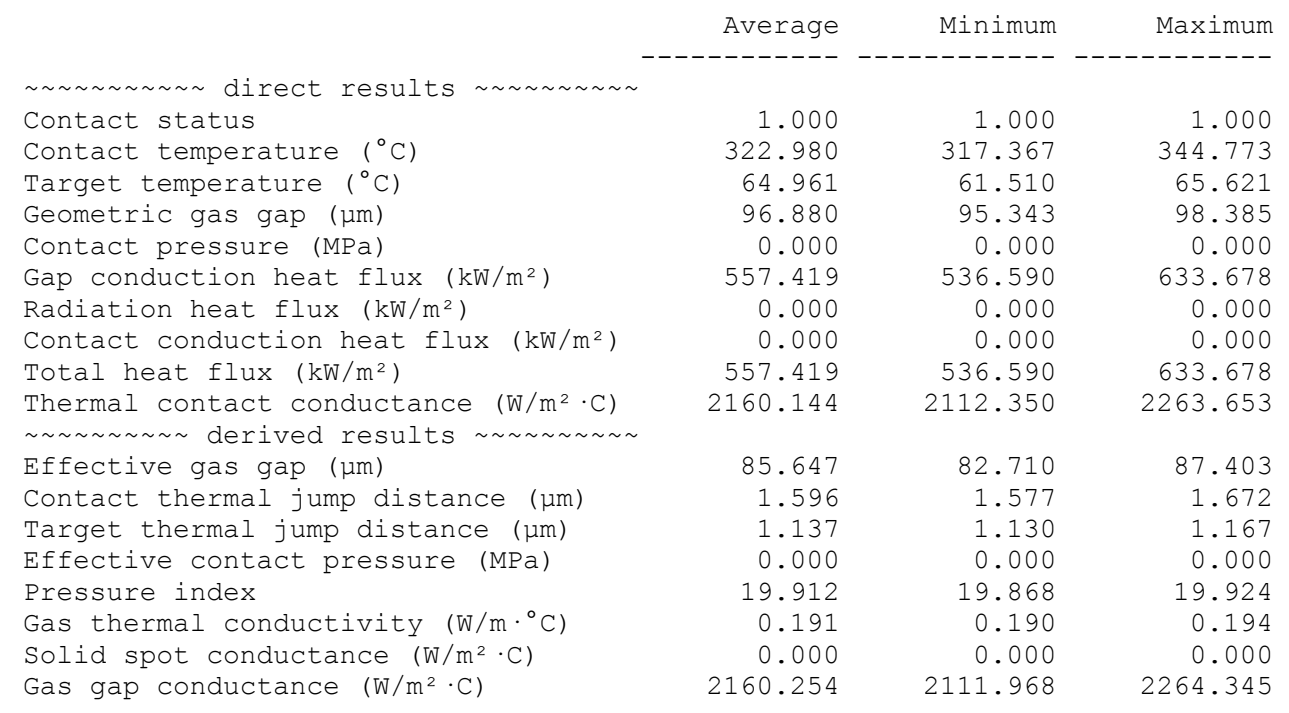

Contact status codes:

$0=$ open/no heat transfer, 1 =near-field contact

$2=$ closed and sliding, $3=$ closed and sticking 


\section{FCF04:}

OUTPUT SUMMARY FILE

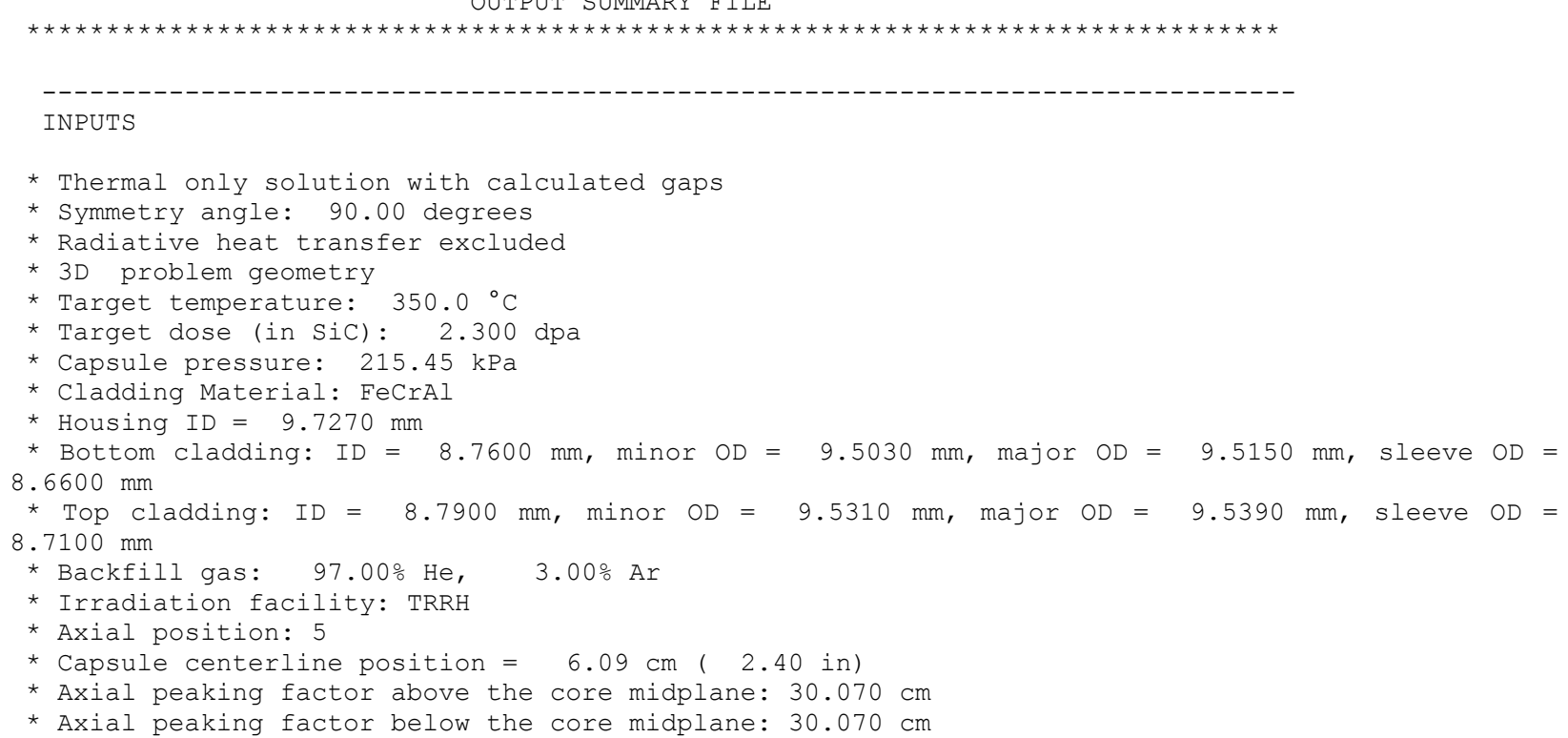

$\begin{array}{rr}\begin{array}{rr}\text { aMidplane } \\ \text { (W) }\end{array} & \begin{array}{r}\text { Load } \\ \text { @Location }\end{array} \\ \text { (W) } \\ 132.8 & 127.4 \\ 15.2 & 13.9 \\ 0.2 & 0.2 \\ 0.2 & 0.2 \\ 0.3 & 0.3 \\ 0.3 & 0.3 \\ 7.2 & 7.1 \\ 40.6 & 39.8 \\ 17.3 & 16.9 \\ 7.2 & 7.0 \\ 305.0 & 298.5 \\ 25.8 & 24.9 \\ 0.6 & 0.6 \\ 7.2 & 6.9 \\ 42.9 & 40.6 \\ 19.5 & 18.4 \\ 7.2 & 6.7 \\ 311.9 & 295.3 \\ 26.4 & 24.4 \\ 0.6 & 0.6 \\ 0.7 & 0.7 \\ 0.7 & 0.7 \\ 0.7 & 0.7 \\ 0.7 & 0.7 \\ 0.2 & 0.2 \\ 0.2 & 0.2 \\ 0.2 & 0.2 \\ & \end{array}$




\begin{tabular}{|c|c|c|c|c|c|}
\hline 32) & Grafoil8 & GRAFOIL & 33700 . & 0.3 & 0.3 \\
\hline 33) & Grafoil9 & GRAFOIL & 33700 . & 0.3 & 0.3 \\
\hline 34) & Grafoillo & GRAFOIL & 33700 . & 0.3 & 0.3 \\
\hline & & ---- & & & 934. \\
\hline
\end{tabular}

CAPSULE TEMPERATURE SUMMARY

\begin{tabular}{|c|c|c|c|c|c|c|c|}
\hline \multicolumn{2}{|l|}{ Name } & Material & Tavg & Tmin & $\operatorname{Tmax}$ & T.025 & Т. 975 \\
\hline 1) & Housing & $A L-6061$ & 63. & 54. & 82. & 54. & 78 . \\
\hline 2) & Cap & $\mathrm{AL}-6061$ & 82. & 80 . & 83. & 80 . & 83. \\
\hline 3) & Grafoill & GRAFOIL & 122. & 113. & 130. & 120. & 123. \\
\hline 4) & Grafoil2 & GRAFOIL & 170. & 161. & 178 . & 168. & 171. \\
\hline 5) & Grafoil6 & GRAFOIL & 428. & 420. & 432. & 422. & 431. \\
\hline 6) & Grafoil7 & GRAFOIL & 426. & 419. & 429. & 421. & 429. \\
\hline 7) & Thimblela & Ti-6Al4V & 400. & 303. & 445 . & 357. & 444. \\
\hline 8) & Clad1 & FeCrAl & 329. & 307 . & 349. & 312. & 343. \\
\hline 9) & Cladl & FeCrAl & 324. & 304 . & 340 . & 307 . & 337. \\
\hline 10) & Thimblelb & Ti-6Al4V & 488. & 372 . & 506. & 453. & 505. \\
\hline 11) & Sleevel & Moly & 472. & 430. & 499. & 436. & 497. \\
\hline 13) & Sleevel & Moly & 499. & 495 . & 500 & 497. & 500. \\
\hline 15) & TM1 & $\operatorname{SiC}(\operatorname{Irr})$ & 474. & 411. & 500 . & 435. & 499. \\
\hline 16) & Thimble2a & $\mathrm{Ti}-6 \mathrm{Al} 4 \mathrm{~V}$ & 444. & 341. & 464 & 419. & 461. \\
\hline 17) & $\mathrm{Clad} 2$ & FeCrAl & 328. & 318. & 364. & 323. & 337. \\
\hline 18) & $\mathrm{Clad2}$ & FeCrAl & 322. & 314. & 353. & 316. & 330. \\
\hline 19) & Thimble2b & $\mathrm{Ti}-6 \mathrm{Al} 4 \mathrm{~V}$ & 436. & 344 . & 442 . & 416. & 442 . \\
\hline 20) & Sleeve2 & Moly & 414. & 405. & 432. & 406. & 428. \\
\hline 22) & Sleeve2 & Moly & 433. & 428. & 436. & 430. & 435. \\
\hline 24) & TM2 & $\operatorname{SiC}(\operatorname{Ir} r)$ & 416. & 409. & 435. & 409. & 432. \\
\hline 25) & Wire1 & Moly & 470. & 455. & 480 & 456. & 480. \\
\hline 26) & Wire2 & Moly & 539. & 526. & 548. & 526. & 548. \\
\hline 27) & Wire3 & Moly & 456. & 441. & 466. & 442 . & 466. \\
\hline 28) & Wire4 & Moly & 474. & 462 . & 483. & 462. & 483. \\
\hline 29) & Grafoil3 & GRAFOIL & 215. & 203. & 227 . & 210. & 219. \\
\hline 30) & Grafoil4 & GRAFOIL & 258. & 240. & 274 . & 245 . & 266. \\
\hline 31) & Grafoil5 & GRAFOIL & 300. & 266. & 326. & 269. & 314. \\
\hline 32) & Grafoil8 & GRAFOIL & 424. & 418. & 429. & 419. & 428. \\
\hline 33) & Grafoil9 & GRAFOIL & 423. & 417 . & 428 & 418. & 428. \\
\hline 34) & Grafoillo & GRAFOIL & 423. & 417. & 428. & 418. & 427. \\
\hline
\end{tabular}

PROPERTY SUMMARY AT THE AVERAGE PART TEMPERATURE

\begin{tabular}{|c|c|c|c|c|c|}
\hline \multicolumn{2}{|l|}{ Name } & \multirow{2}{*}{ Material } & $\begin{array}{l}\text { Thermal } \\
\text { Cond. } \\
\left(\mathrm{W} / \mathrm{m} \cdot{ }^{\circ} \mathrm{C}\right)\end{array}$ & $\begin{array}{l}\text { Thermal } \\
\text { Exp. } \\
\text { Coeff. } \\
\left(\mu \mathrm{m} / \mathrm{m} \cdot{ }^{\circ} \mathrm{C}\right)\end{array}$ & $\begin{array}{l}\text { Emis } \\
(---)\end{array}$ \\
\hline & -1 & & --------- & --------- & ------ \\
\hline 1) & Housing & $\mathrm{AL}-6061$ & 167.044 & 24.21 & 0.050 \\
\hline 2) & Cap & $A L-6061$ & 169.190 & 0.00 & 0.050 \\
\hline 3) & Grafoill & GRAFOIL & 38.000 & 1.00 & 0.500 \\
\hline 4) & Grafoil2 & GRAFOIL & 38.000 & 1.00 & 0.500 \\
\hline 5) & Grafoil 6 & GRAFOIL & 38.000 & 1.00 & 0.500 \\
\hline 6) & Grafoil7 & GRAFOIL & 38.000 & 1.00 & 0.500 \\
\hline 7) & Thimblela & Ti-6Al4V & 14.575 & 10.05 & 0.392 \\
\hline 8) & Cladl & FeCrAl & 15.800 & 11.32 & 0.143 \\
\hline 9) & Cladl & FeCrAl & 15.716 & 11.30 & 0.143 \\
\hline 10) & Thimble1b & Ti-6Al4V & 16.410 & 10.23 & 0.404 \\
\hline 11) & Sleeve1 & Moly & 120.207 & 5.18 & 0.074 \\
\hline 13) & Sleevel & Moly & 119.120 & 0.00 & 0.077 \\
\hline 15) & TM1 & $\operatorname{SiC}(\operatorname{Irr})$ & 8.658 & 3.71 & 0.900 \\
\hline 16) & Thimble $2 \mathrm{a}$ & $\mathrm{Ti}-6 \mathrm{Al} 4 \mathrm{~V}$ & 15.474 & 10.14 & 0.400 \\
\hline 17) & $\mathrm{Clad} 2$ & FeCrAl & 15.785 & 11.31 & 0.143 \\
\hline 18) & $\mathrm{Clad} 2$ & FeCrAl & 15.683 & 11.29 & 0.143 \\
\hline 19) & Thimble2b & Ti-6Al4V & 15.300 & 10.12 & 0.399 \\
\hline 20) & Sleeve2 & Moly & 122.535 & 5.12 & 0.069 \\
\hline 22) & Sleeve2 & Moly & 121.745 & 0.00 & 0.071 \\
\hline 24) & TM2 & $\operatorname{SiC}(\operatorname{Irr})$ & 8.703 & 3.58 & 0.900 \\
\hline 25) & Wire1 & Moly & 120.295 & 0.00 & 0.074 \\
\hline
\end{tabular}




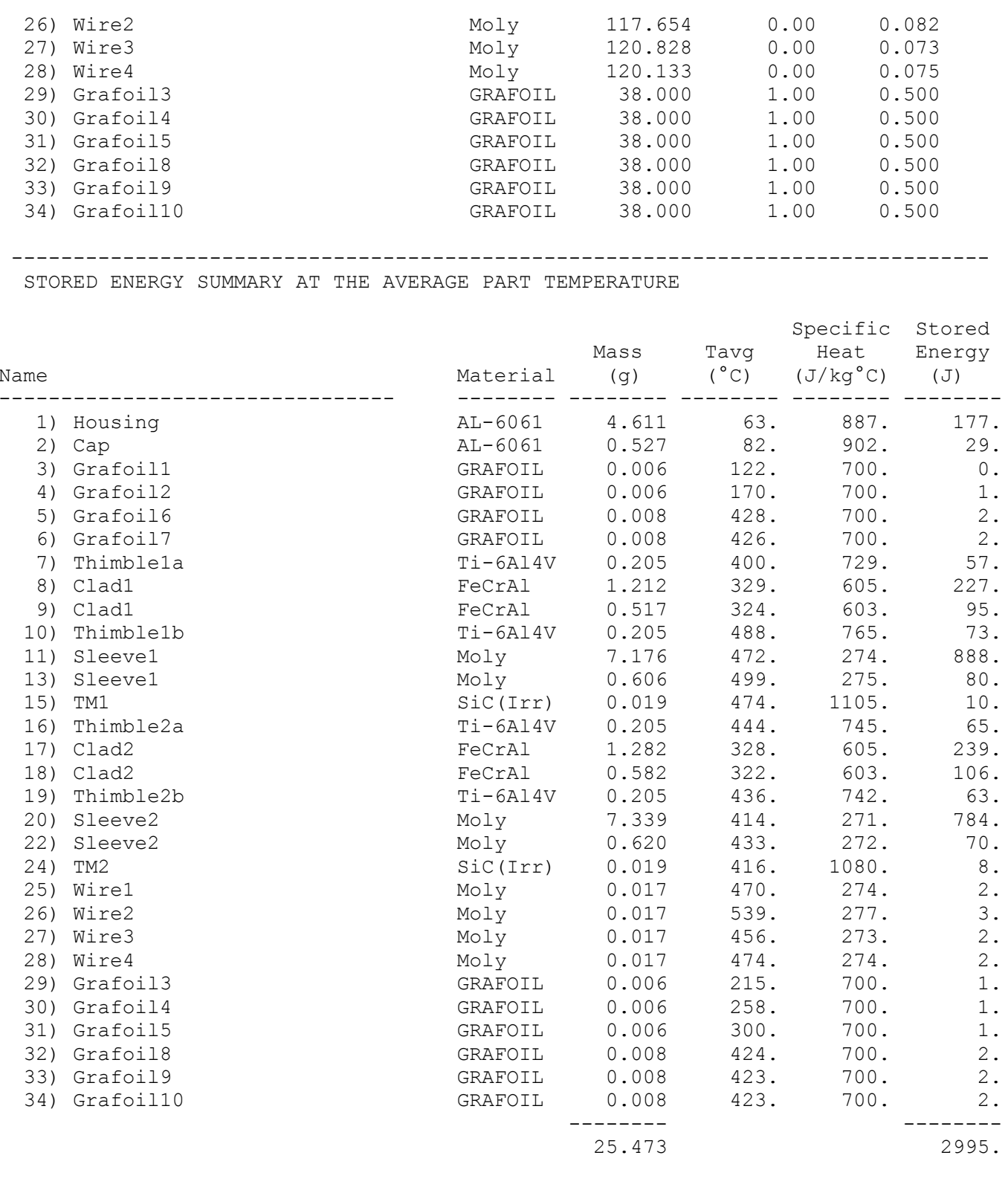

CLAD TO HOUSING GAP REPORTS

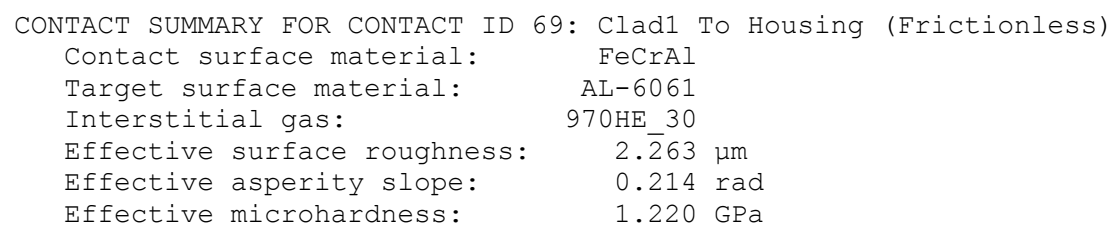


Gap conduction heat flux $\left(\mathrm{kW} / \mathrm{m}^{2}\right)$

Radiation heat flux $\left(\mathrm{kW} / \mathrm{m}^{2}\right)$

Contact conduction heat flux $\left(\mathrm{kW} / \mathrm{m}^{2}\right)$

Total heat flux $\left(\mathrm{kW} / \mathrm{m}^{2}\right)$

Thermal contact conductance $\left(W / \mathrm{m}^{2} \cdot \mathrm{C}\right)$

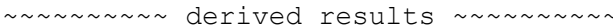

Effective gas gap ( $\mathrm{m}$ )

Contact thermal jump distance ( $\mu \mathrm{m})$

Target thermal jump distance ( $\mu m$ )

Effective contact pressure (MPa)

Pressure index

Gas thermal conductivity $\left(\mathrm{W} / \mathrm{m} \cdot{ }^{\circ} \mathrm{C}\right)$

Solid spot conductance $\left(\mathrm{W} / \mathrm{m}^{2} \cdot \mathrm{C}\right)$

Gas gap conductance $\left(W / \mathrm{m}^{2} \cdot \mathrm{C}\right)$

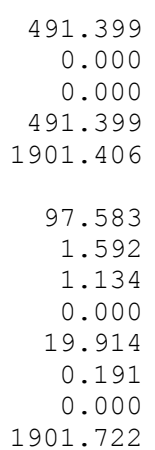

491.399

0.000

0.000

491.399

1901.406

97.583

1.592

1.134

0.000

19.914

0.191

0.000

1901.722

443.884

0.000

0.000

443.884

1816.091

93.700

1.529

1.108

0.000

19.884

0.188

0.000

1816.524
538.091

0.000

0.000

538.091

1988.463

101.282

1.641

1.154

0.000

19.949

0.193

0.000

1989.083

Contact status codes:

$0=$ open/no heat transfer, 1 =near-field contact

2=closed and sliding, $3=$ closed and sticking

CONTACT SUMMARY FOR CONTACT ID 71: Clad2 TO Housing (Frictionless)

Contact surface material: FeCrAl

Target surface material: AL-6061

Interstitial gas: $\quad 970 \mathrm{HE} 30$

Effective surface roughness: $2 . \overline{2} 63 \mu \mathrm{m}$

Effective asperity slope: $0.214 \mathrm{rad}$

Effective microhardness: $\quad 1.220 \mathrm{GPa}$

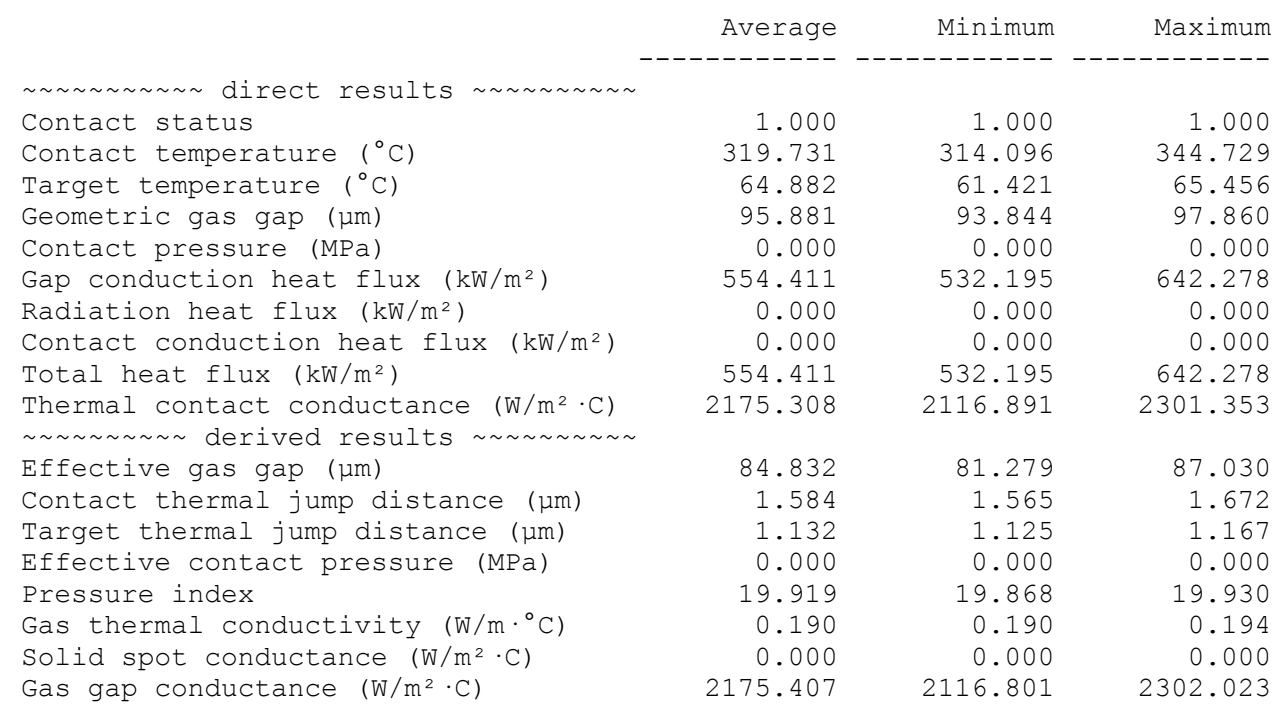

Contact status codes:

$0=$ open/no heat transfer 1 =near-field contact

$2=$ closed and sliding, $3=c l o s e d$ and sticking 


\section{FCF05:}

OUTPUT SUMMARY FILE

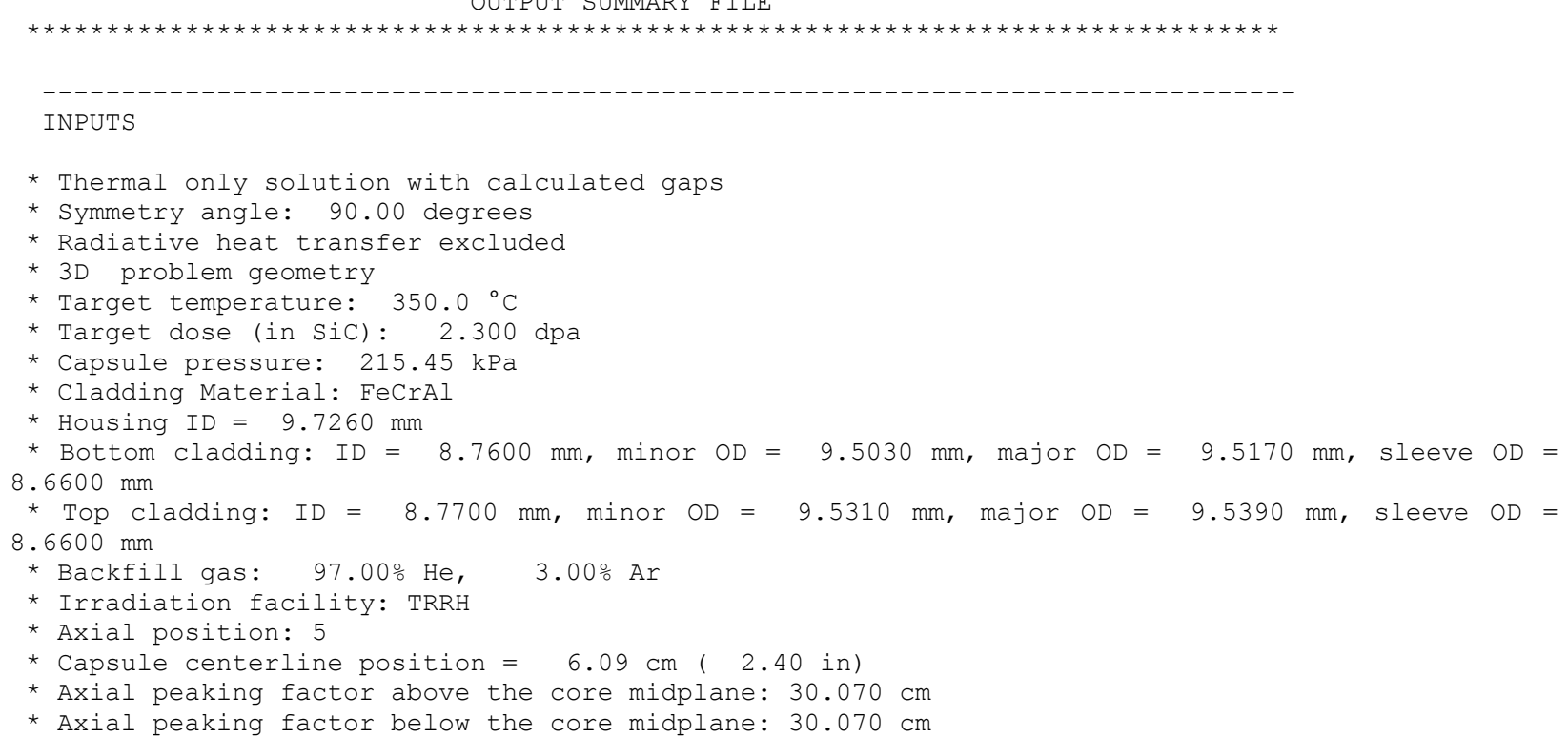

$\begin{array}{ll}\text { Part } \\ \text { 1) } & \text { Housing } \\ \text { 2) } & \text { Cap } \\ \text { 3) } & \text { Grafoil1 } \\ \text { 4) } & \text { Grafoil2 } \\ \text { 5) } & \text { Grafoil6 } \\ \text { 6) } & \text { Grafoil7 } \\ \text { 7) } & \text { Thimblela } \\ \text { 8) } & \text { Clad1 } \\ \text { 9) } & \text { Clad1 } \\ \text { 10) } & \text { Thimble1b } \\ \text { 11) } & \text { Sleeve1 } \\ \text { 13) } & \text { Sleeve1 } \\ \text { 15) } & \text { TM1 } \\ \text { 16) } & \text { Thimble2a } \\ \text { 17) } & \text { Clad2 } \\ \text { 18) } & \text { Clad2 } \\ \text { 19) } & \text { Thimble2b } \\ \text { 20) } & \text { Sleeve2 } \\ \text { 22) } & \text { Sleeve2 } \\ \text { 24) } & \text { TM2 } \\ \text { 25) } & \text { Wire1 } \\ \text { 26) } & \text { Wire2 } \\ \text { 27) } & \text { Wire3 } \\ \text { 28) } & \text { Wire4 } \\ \text { 29) } & \text { Grafoil3 } \\ \text { 30) } & \text { Grafoil4 } \\ \text { 31) } & \text { Grafoil5 }\end{array}$

$\begin{array}{lr}\text { Material } & (\mathrm{W} / \mathrm{kg}) \\ ----- & --\cdot- \\ \text { AL-6061 } & 28800 . \\ \text { AL-6061 } & 28800 . \\ \text { GRAFOIL } & 33700 . \\ \text { GRAFOIL } & 33700 . \\ \text { GRAFOIL } & 33700 . \\ \text { GRAFOIL } & 33700 . \\ \text { Ti-6Al4V } & 35200 . \\ \text { FeCrAl } & 33500 . \\ \text { FeCrAl } & 33500 . \\ \text { Ti-6Al4V } & 35200 . \\ \text { Moly } & 42500 . \\ \text { Moly } & 42500 . \\ \text { SiC(Irr) } & 32900 . \\ \text { Ti-6Al4V } & 35200 . \\ \text { FeCrAl } & 33500 . \\ \text { FeCrAl } & 33500 . \\ \text { Ti-6Al4V } & 35200 . \\ \text { Moly } & 42500 . \\ \text { Moly } & 42500 . \\ \text { SiC(Irr) } & 32900 . \\ \text { Moly } & 42500 . \\ \text { Moly } & 42500 . \\ \text { Moly } & 42500 . \\ \text { Moly } & 42500 . \\ \text { GRAFOIL } & 33700 . \\ \text { GRAFOIL } & 33700 . \\ \text { GRAFOIL } & 33700 . \\ & \end{array}$

$\begin{array}{rr}\begin{array}{r}\text { aMidplane } \\ \text { (W) }\end{array} & \begin{array}{r}\text { Load } \\ \text { QLocation }\end{array} \\ 132.9 & 127.5 \\ 15.2 & 13.9 \\ 0.2 & 0.2 \\ 0.2 & 0.2 \\ 0.3 & 0.3 \\ 0.3 & 0.3 \\ 7.2 & 7.1 \\ 42.2 & 41.3 \\ 17.4 & 17.0 \\ 7.2 & 7.0 \\ 305.0 & 298.5 \\ 25.8 & 24.9 \\ 0.6 & 0.6 \\ 7.2 & 6.9 \\ 42.9 & 40.6 \\ 19.5 & 18.4 \\ 7.2 & 6.7 \\ 305.0 & 288.7 \\ 25.8 & 23.9 \\ 0.6 & 0.6 \\ 0.7 & 0.7 \\ 0.7 & 0.7 \\ 0.7 & 0.7 \\ 0.7 & 0.7 \\ 0.2 & 0.2 \\ 0.2 & 0.2 \\ 0.2 & 0.2\end{array}$




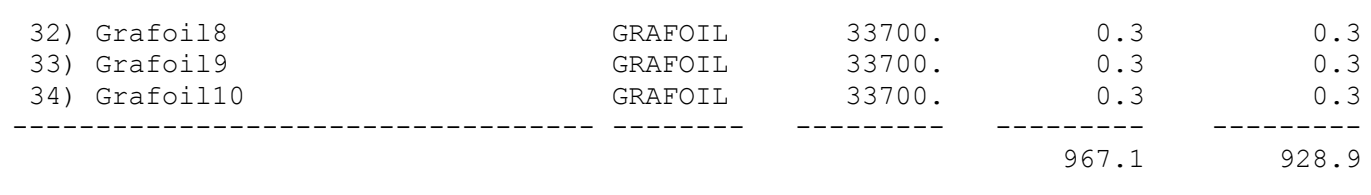

CAPSULE TEMPERATURE SUMMARY

\begin{tabular}{|c|c|c|c|c|c|c|c|}
\hline \multicolumn{2}{|l|}{ Name } & Material & Tavg & Tmin & Tmax & $\begin{array}{l}\text { T.025 } \\
-----\end{array}$ & T.975 \\
\hline 1) & Housing & $\mathrm{AL}-6061$ & 63 & 54. & 81. & 54. & 78. \\
\hline 2) & Cap & $A L-6061$ & 82. & 80. & 83. & 80. & 83. \\
\hline 3) & Grafoill & GRAFOIL & 120. & 111. & 128. & 119. & 121. \\
\hline 4) & Grafoil2 & GRAFOIL & 166. & 158. & 175. & 165. & 167. \\
\hline 5) & Grafoil 6 & GRAFOIL & 461. & 452 . & 466. & 454. & 465. \\
\hline 6) & Grafoil7 & GRAFOIL & 459. & 451. & 462. & 453. & 462. \\
\hline 7) & Thimblela & $\mathrm{Ti}-6 \mathrm{Al} 4 \mathrm{~V}$ & 390. & 296. & 433. & 348. & 432. \\
\hline 8) & Clad1 & FeCrAl & 332. & 308 . & 355. & 313. & 349. \\
\hline 9) & Cladl & FeCrAl & 326. & 305. & 346. & 308. & 343. \\
\hline 10) & Thimble1b & $\mathrm{Ti}-6 \mathrm{~A} 14 \mathrm{~V}$ & 490. & 373. & 502. & 458. & 501. \\
\hline 11) & Sleeve1 & Moly & 460. & 418. & 493. & 424. & 490. \\
\hline 13) & Sleevel & Moly & 494. & 490. & 496. & 492. & 496. \\
\hline 15) & TM1 & $\operatorname{SiC}(\operatorname{Irr})$ & 462. & 400 & 494. & 423. & 493. \\
\hline 16) & Thimble2a & Ti-6Al4V & 466. & 347 . & 480. & 433. & 477. \\
\hline 17) & $\mathrm{Clad} 2$ & FeCrAl & 320. & 311. & 363. & 316. & 328. \\
\hline 18) & $\mathrm{Clad} 2$ & FeCrAl & 314 . & 307 . & 353. & 309. & 322. \\
\hline 19) & Thimble2b & $\mathrm{Ti}-6 \mathrm{Al} 4 \mathrm{~V}$ & 471. & 364. & 478. & 447. & 477. \\
\hline 20) & Sleeve2 & Moly & 449. & 442 . & 468. & 443. & 465. \\
\hline 22) & Sleeve2 & Moly & 470. & 465. & 472. & 467. & 472 . \\
\hline 24) & TM2 & $\operatorname{SiC}(\operatorname{Irr})$ & 452 . & 446. & 469. & 446. & 468. \\
\hline 25) & Wire1 & Moly & 456. & 441. & 466. & 442. & 466. \\
\hline 26) & Wire2 & Moly & 534. & 521. & 544. & 522. & 544. \\
\hline 27) & Wire3 & Moly & 482. & 465. & 493. & 467. & 493. \\
\hline 28) & Wire4 & Moly & 509. & 497. & 518. & 497. & 518. \\
\hline 29) & Grafoil3 & GRAFOIL & 210. & 199. & 221. & 205. & 214. \\
\hline 30) & Grafoil4 & GRAFOIL & 252 . & 234. & 268 . & 240. & 260. \\
\hline 31) & Grafoil5 & GRAFOIL & 293. & 260 & 318. & 263. & 307. \\
\hline 32) & Grafoil8 & GRAFOIL & 457. & 450 & 461. & 451. & 461. \\
\hline 33) & Grafoil9 & GRAFOIL & 456. & 449. & 461. & 450. & 461. \\
\hline 34) & Grafoillo & GRAFOIL & 455. & 448. & 461. & 449. & 460. \\
\hline
\end{tabular}

PROPERTY SUMMARY AT THE AVERAGE PART TEMPERATURE

\begin{tabular}{|c|c|c|c|c|c|}
\hline \multicolumn{2}{|l|}{ Name } & \multirow{2}{*}{ Material } & $\begin{array}{l}\text { Thermal } \\
\text { Cond. } \\
\left(\mathrm{W} / \mathrm{m} \cdot{ }^{\circ} \mathrm{C}\right)\end{array}$ & $\begin{array}{l}\text { Thermal } \\
\text { Exp. } \\
\text { Coeff. } \\
\left(\mu \mathrm{m} / \mathrm{m} \cdot{ }^{\circ} \mathrm{C}\right)\end{array}$ & $\begin{array}{l}\text { Emis } \\
(---)\end{array}$ \\
\hline & -- & & --------- & --------- & ------ \\
\hline 1) & Housing & $\mathrm{AL}-6061$ & 167.034 & 24.21 & 0.050 \\
\hline 2) & Cap & $A L-6061$ & 169.192 & 0.00 & 0.050 \\
\hline 3) & Grafoill & GRAFOIL & 38.000 & 1.00 & 0.500 \\
\hline 4) & Grafoil2 & GRAFOIL & 38.000 & 1.00 & 0.500 \\
\hline 5) & Grafoil 6 & GRAFOIL & 38.000 & 1.00 & 0.500 \\
\hline 6) & Grafoil7 & GRAFOIL & 38.000 & 1.00 & 0.500 \\
\hline 7) & Thimblela & Ti-6Al4V & 14.368 & 10.03 & 0.390 \\
\hline 8) & Cladl & FeCrAl & 15.836 & 11.33 & 0.143 \\
\hline 9) & Cladl & FeCrAl & 15.748 & 11.30 & 0.143 \\
\hline 10) & Thimble1b & $\mathrm{Ti}-6 \mathrm{Al} 4 \mathrm{~V}$ & 16.447 & 10.23 & 0.404 \\
\hline 11) & Sleeve1 & Moly & 120.678 & 5.17 & 0.073 \\
\hline 13) & Sleevel & Moly & 119.316 & 0.00 & 0.077 \\
\hline 15) & TM1 & $\operatorname{SiC}(\operatorname{Irr})$ & 8.667 & 3.69 & 0.900 \\
\hline 16) & Thimble $2 \mathrm{a}$ & Ti-6Al4V & 15.957 & 10.18 & 0.403 \\
\hline 17) & $\mathrm{Clad} 2$ & FeCrAl & 15.662 & 11.28 & 0.143 \\
\hline 18) & $\mathrm{Clad} 2$ & FeCrAl & 15.562 & 11.26 & 0.143 \\
\hline 19) & Thimble2b & Ti-6Al4V & 16.059 & 10.19 & 0.403 \\
\hline 20) & Sleeve2 & Moly & 121.101 & 5.16 & 0.072 \\
\hline 22) & Sleeve2 & Moly & 120.289 & 0.00 & 0.074 \\
\hline 24) & TM2 & $\operatorname{SiC}(\operatorname{Irr})$ & 8.675 & 3.66 & 0.900 \\
\hline 25) & Wire1 & Moly & 120.834 & 0.00 & 0.073 \\
\hline
\end{tabular}




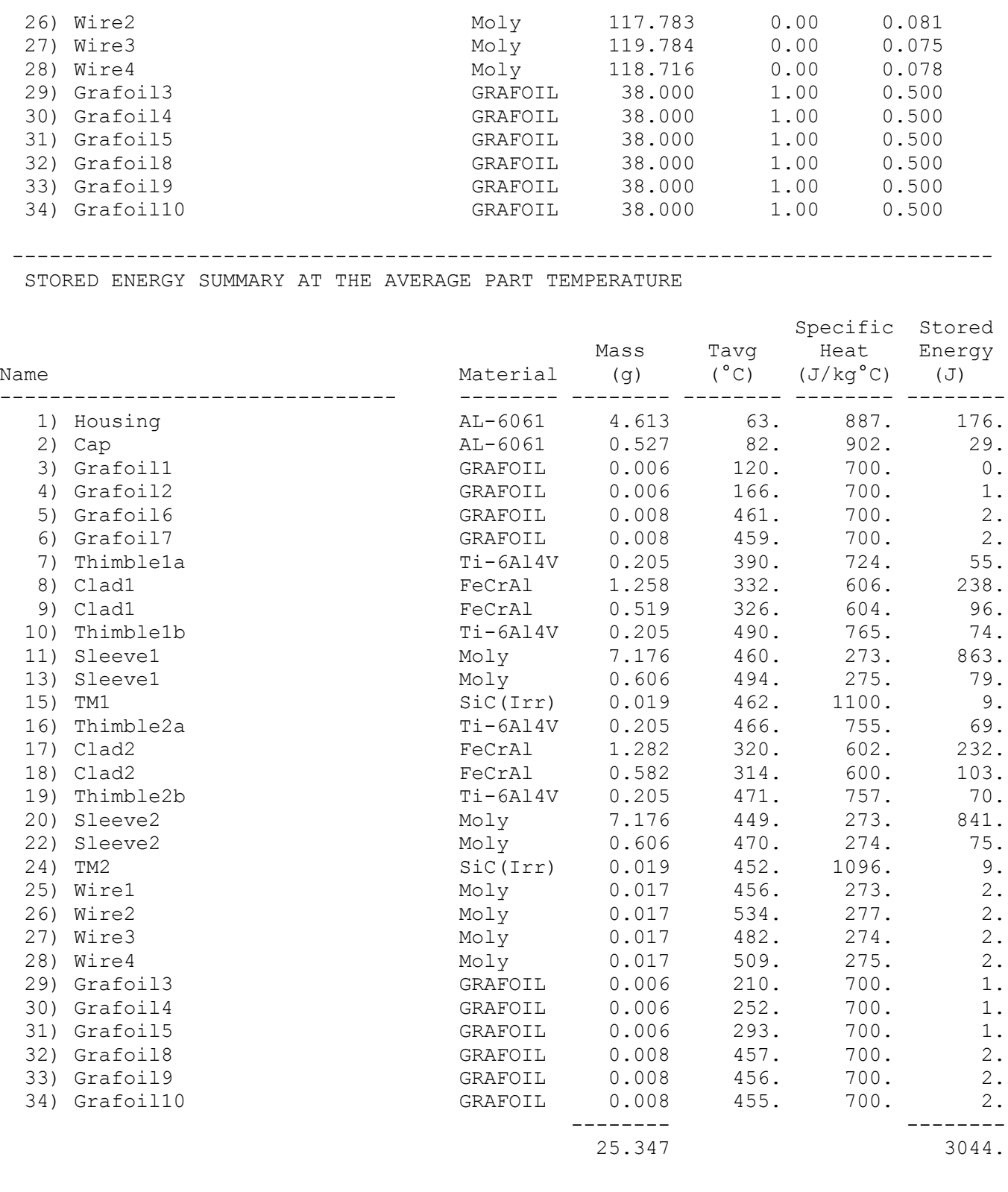

CLAD TO HOUSING GAP REPORTS

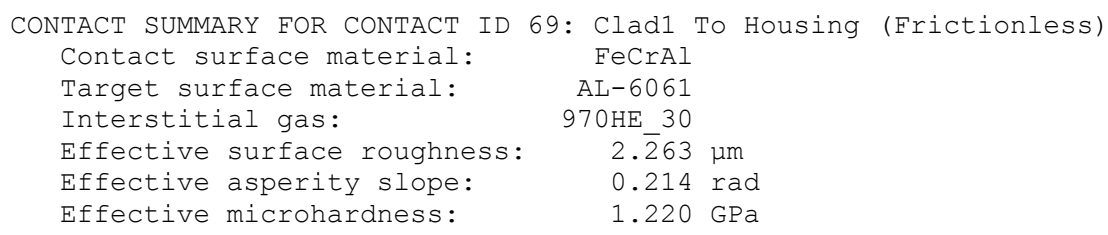


Gap conduction heat flux $\left(\mathrm{kW} / \mathrm{m}^{2}\right)$

Radiation heat flux $\left(\mathrm{kW} / \mathrm{m}^{2}\right)$

Contact conduction heat flux $\left(\mathrm{kW} / \mathrm{m}^{2}\right)$

Total heat flux $\left(\mathrm{kW} / \mathrm{m}^{2}\right)$

Thermal contact conductance $\left(\mathrm{W} / \mathrm{m}^{2} \cdot \mathrm{C}\right)$

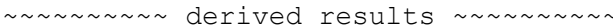

Effective gas gap ( $\mathrm{m}$ )

Contact thermal jump distance ( $\mu \mathrm{m})$

Target thermal jump distance ( $\mu m$ )

Effective contact pressure (MPa)

Pressure index

Gas thermal conductivity $\left(\mathrm{W} / \mathrm{m} \cdot{ }^{\circ} \mathrm{C}\right)$

Solid spot conductance $\left(\mathrm{W} / \mathrm{m}^{2} \cdot \mathrm{C}\right)$

Gas gap conductance $\left(W / \mathrm{m}^{2} \cdot \mathrm{C}\right)$
501.313

0.000

0.000

501.313

1925.907

96.484

1.600

1.138

0.000

19.909

0.191

0.000

1926.155
449.055

0.000

0.000

449.055

1826.613

91.926

1.531

1.109

0.000

19.872

0.188

0.000

1827.002
559.829

0.000

0.000

559.829

2033.142

100.758

1.662

1.162

0.000

19.948

0.193

0.000

2033.305

Contact status codes:

$0=$ open/no heat transfer, 1 =near-field contact

2=closed and sliding, $3=$ closed and sticking

CONTACT SUMMARY FOR CONTACT ID 71: Clad2 TO Housing (Frictionless)

Contact surface material: FeCrAl

Target surface material: AL-6061

Interstitial gas: $970 \mathrm{HE} 30$

Effective surface roughness: $2 . \overline{2} 63 \mu \mathrm{m}$

Effective asperity slope: $0.214 \mathrm{rad}$

Effective microhardness: $\quad 1.220 \mathrm{GPa}$

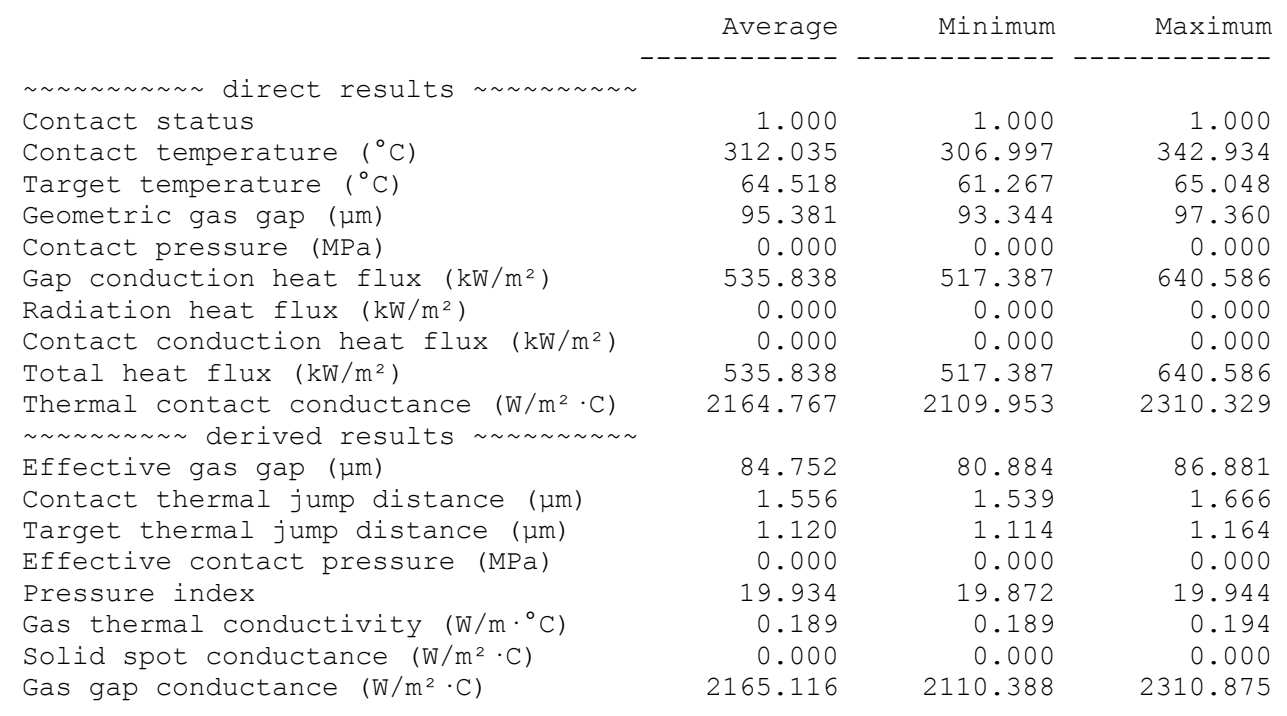

Contact status codes:

$0=$ open/no heat transfer, 1 =near-field contact

$2=$ closed and sliding, $3=c l o s e d$ and sticking 


\section{FCF06:}

OUTPUT SUMMARY FILE

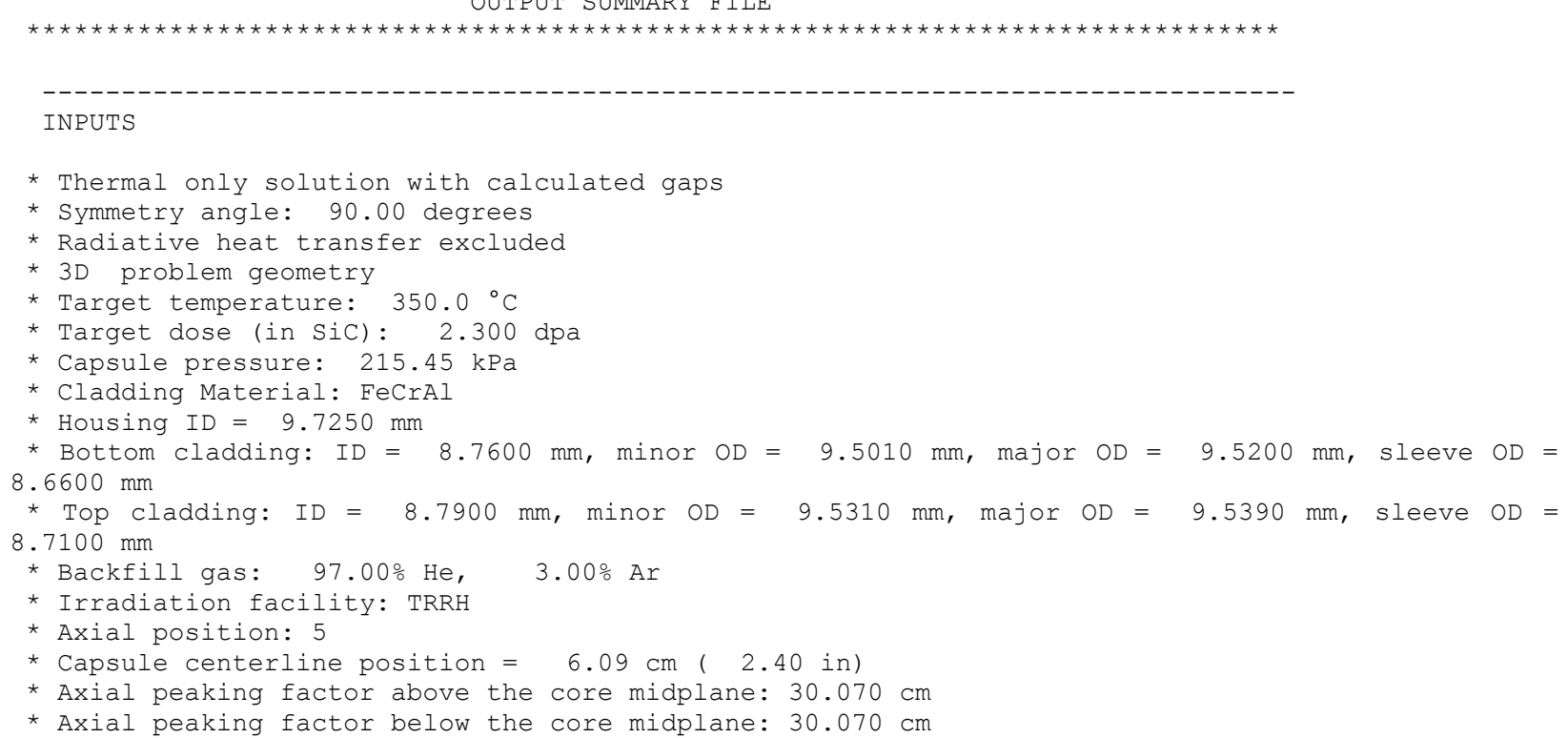

$\begin{array}{rr}\begin{array}{rr}\text { aMidplane } \\ \text { (W) }\end{array} & \begin{array}{r}\text { Load } \\ \text { @Location }\end{array} \\ \text { (W) } \\ 132.9 & 127.6 \\ 15.2 & 13.9 \\ 0.2 & 0.2 \\ 0.2 & 0.2 \\ 0.3 & 0.3 \\ 0.3 & 0.3 \\ 7.2 & 7.1 \\ 40.6 & 39.8 \\ 17.4 & 17.1 \\ 7.2 & 7.0 \\ 305.0 & 298.5 \\ 25.8 & 24.9 \\ 0.6 & 0.6 \\ 7.2 & 6.9 \\ 42.9 & 40.6 \\ 19.5 & 18.4 \\ 7.2 & 6.7 \\ 311.9 & 295.3 \\ 26.4 & 24.4 \\ 0.6 & 0.6 \\ 0.7 & 0.7 \\ 0.7 & 0.7 \\ 0.7 & 0.7 \\ 0.7 & 0.7 \\ 0.2 & 0.2 \\ 0.2 & 0.2 \\ 0.2 & 0.2 \\ & \end{array}$




\begin{tabular}{|c|c|c|c|c|c|}
\hline 32) & Grafoil8 & GRAFOIL & 33700 . & 0.3 & 0.3 \\
\hline 33) & Grafoil9 & GRAFOIL & 33700 . & 0.3 & 0.3 \\
\hline 34) & Grafoillo & GRAFOIL & 33700 . & 0.3 & 0.3 \\
\hline & & -----1 & & & 934.6 \\
\hline
\end{tabular}

CAPSULE TEMPERATURE SUMMARY

\begin{tabular}{llrrrrr} 
Name & Material & Tavg & Tmin & Tmax & T.025 & T. 975 \\
\hline 1) Housing & AL-6061 & 63. & 54. & 81. & 54. & 78. \\
2) Cap & AL-6061 & 82. & 80. & 83. & 80. & 83. \\
3) Grafoil1 & GRAFOIL & 122. & 112. & 129. & 120. & 122. \\
4) Grafoil2 & GRAFOIL & 169. & 160. & 178. & 167. & 170. \\
5) Grafoil6 & GRAFOIL & 426. & 418. & 430. & 419. & 429. \\
6) Grafoil7 & GRAFOIL & 424. & 417. & 427. & 418. & 427. \\
7) Thimble1a & Ti-6Al4V & 398. & 298. & 443. & 354. & 441. \\
8) Clad1 & FeCrAl & 326. & 304. & 347. & 309. & 341. \\
9) Clad1 & FeCrAl & 321. & 301. & 338. & 304. & 335. \\
10) Thimble1b & Ti-6Al4V & 485. & 366. & 503. & 450. & 502. \\
11) Sleeve1 & Moly & 469. & 427. & 496. & 434. & 494. \\
13) Sleeve1 & Moly & 496. & 492. & 497. & 494. & 497. \\
15) TM1 & SiC(Irr) & 471. & 409. & 497. & 432. & 496. \\
16) Thimble2a & Ti-6Al4V & 442. & 336. & 462. & 416. & 458. \\
17) Clad2 & FeCrAl & 326. & 316. & 361. & 321. & 335. \\
18) Clad2 & FeCrAl & 320. & 312. & 351. & 314. & 328. \\
19) Thimble2b & Ti-6Al4V & 434. & 339. & 440. & 413. & 439. \\
20) Sleeve2 & Moly & 411. & 402. & 429. & 404. & 426. \\
22) Sleeve2 & Moly & 431. & 426. & 433. & 428. & 433. \\
24) TM2 & SiC(Irr) & 414. & 407. & 432. & 407. & 429. \\
25) Wire1 & Moly & 467. & 452. & 477. & 453. & 477. \\
26) Wire2 & Moly & 536. & 523. & 545. & 523. & 545. \\
27) Wire3 & Moly & 454. & 438. & 464. & 439. & 464. \\
28) Wire4 & Moly & 471. & 459. & 481. & 460. & 481. \\
29) Grafoil3 & GRAFOIL & 214. & 202. & 225. & 208. & 217. \\
30) Grafoil4 & GRAFOIL & 257. & 239. & 273. & 244. & 265. \\
31) Grafoil5 & GRAFOIL & 299. & 264. & 324. & 268. & 312. \\
32) Grafoil8 & GRAFOIL & 422. & 416. & 426. & 417. & 426. \\
33) Grafoil9 & GRAFOIL & 421. & 415. & 426. & 416. & 425. \\
34) Grafoil10 & GRAFOIL & 420. & 415. & 425. & 415. & 425. \\
& & & & & &
\end{tabular}

PROPERTY SUMMARY AT THE AVERAGE PART TEMPERATURE

\begin{tabular}{|c|c|c|c|c|c|}
\hline \multicolumn{2}{|l|}{ Name } & \multirow{2}{*}{ Material } & $\begin{array}{l}\text { Thermal } \\
\text { Cond. } \\
\left(\mathrm{W} / \mathrm{m} \cdot{ }^{\circ} \mathrm{C}\right)\end{array}$ & $\begin{array}{l}\text { Thermal } \\
\text { Exp. } \\
\text { Coeff. } \\
\left(\mu \mathrm{m} / \mathrm{m} \cdot{ }^{\circ} \mathrm{C}\right)\end{array}$ & $\begin{array}{l}\text { Emis } \\
(---)\end{array}$ \\
\hline & -1 & & --------- & --------- & ------ \\
\hline 1) & Housing & $\mathrm{AL}-6061$ & 167.044 & 24.21 & 0.050 \\
\hline 2) & Cap & $A L-6061$ & 169.190 & 0.00 & 0.050 \\
\hline 3) & Grafoill & GRAFOIL & 38.000 & 1.00 & 0.500 \\
\hline 4) & Grafoil2 & GRAFOIL & 38.000 & 1.00 & 0.500 \\
\hline 5) & Grafoil 6 & GRAFOIL & 38.000 & 1.00 & 0.500 \\
\hline 6) & Grafoil7 & GRAFOIL & 38.000 & 1.00 & 0.500 \\
\hline 7) & Thimblela & Ti-6Al4V & 14.528 & 10.05 & 0.392 \\
\hline 8) & Cladl & FeCrAl & 15.750 & 11.30 & 0.143 \\
\hline 9) & Cladl & FeCrAl & 15.665 & 11.28 & 0.143 \\
\hline 10) & Thimble1b & Ti-6Al4V & 16.358 & 10.22 & 0.404 \\
\hline 11) & Sleeve1 & Moly & 120.322 & 5.17 & 0.074 \\
\hline 13) & Sleevel & Moly & 119.237 & 0.00 & 0.077 \\
\hline 15) & TM1 & $\operatorname{SiC}(\operatorname{Irr})$ & 8.660 & 3.71 & 0.900 \\
\hline 16) & Thimble $2 \mathrm{a}$ & Ti-6Al4V & 15.417 & 10.13 & 0.400 \\
\hline 17) & $\mathrm{Clad} 2$ & FeCrAl & 15.751 & 11.30 & 0.143 \\
\hline 18) & $\mathrm{Clad} 2$ & FeCrAl & 15.648 & 11.28 & 0.143 \\
\hline 19) & Thimble2b & Ti-6Al4V & 15.250 & 10.11 & 0.399 \\
\hline 20) & Sleeve2 & Moly & 122.626 & 5.12 & 0.068 \\
\hline 22) & Sleeve2 & Moly & 121.834 & 0.00 & 0.070 \\
\hline 24) & TM2 & $\operatorname{SiC}(\operatorname{Irr})$ & 8.705 & 3.58 & 0.900 \\
\hline 25) & Wire1 & Moly & 120.404 & 0.00 & 0.074 \\
\hline
\end{tabular}




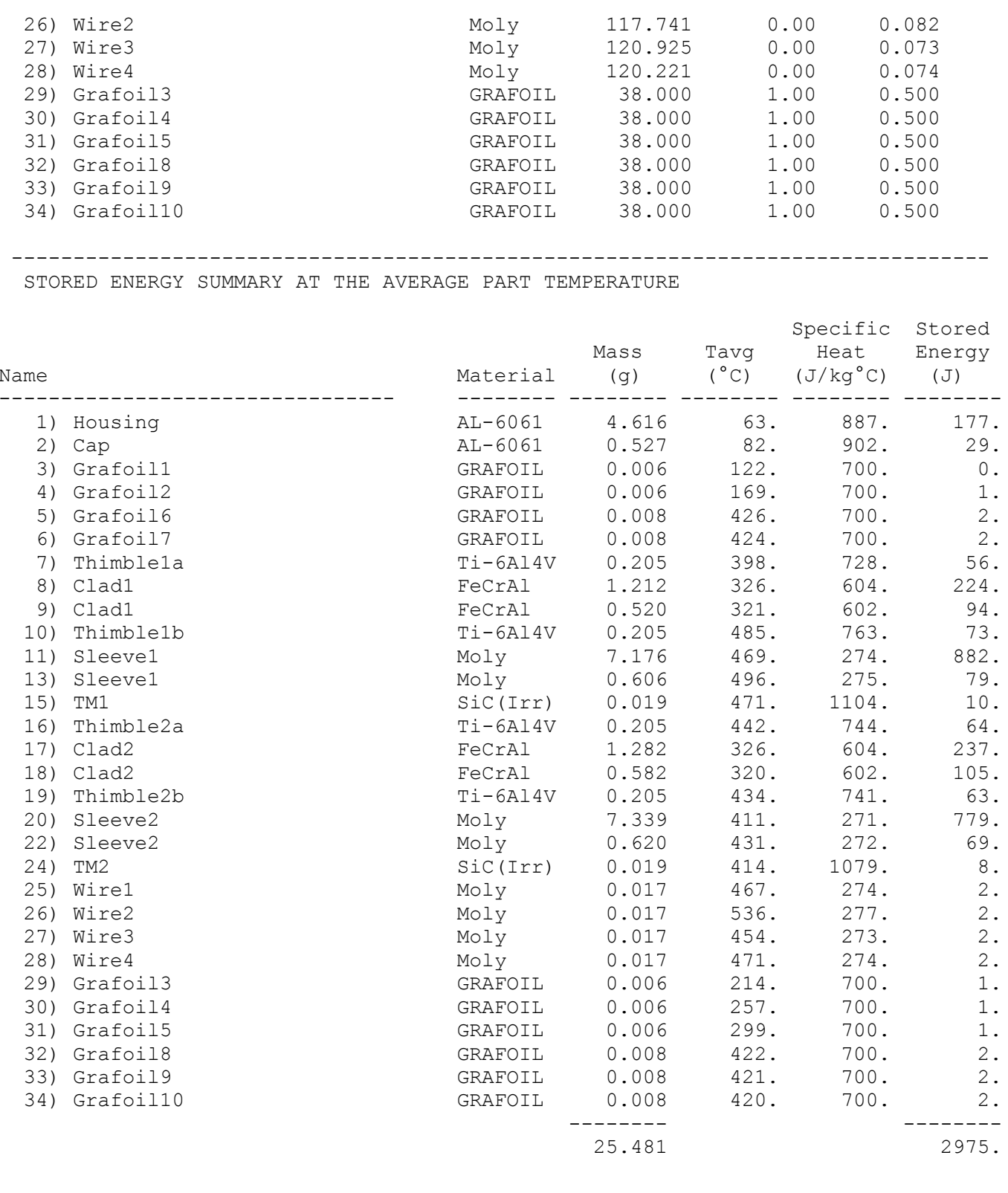

CLAD TO HOUSING GAP REPORTS

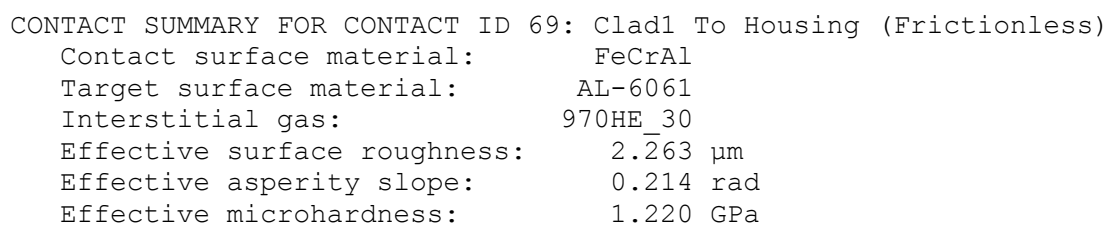


Gap conduction heat flux $\left(\mathrm{kW} / \mathrm{m}^{2}\right)$

Radiation heat flux $\left(\mathrm{kW} / \mathrm{m}^{2}\right)$

Contact conduction heat flux $\left(\mathrm{kW} / \mathrm{m}^{2}\right)$

Total heat flux $\left(\mathrm{kW} / \mathrm{m}^{2}\right)$

Thermal contact conductance $\left(\mathrm{W} / \mathrm{m}^{2} \cdot \mathrm{C}\right)$

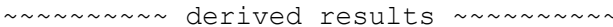

Effective gas gap ( $\mathrm{m}$ )

Contact thermal jump distance ( $\mu \mathrm{m})$

Target thermal jump distance ( $\mu m$ )

Effective contact pressure (MPa)

Pressure index

Gas thermal conductivity $\left(\mathrm{W} / \mathrm{m} \cdot{ }^{\circ} \mathrm{C}\right)$

Solid spot conductance $\left(\mathrm{W} / \mathrm{m}^{2} \cdot \mathrm{C}\right)$

Gas gap conductance $\left(W / \mathrm{m}^{2} \cdot \mathrm{C}\right)$

$$
\begin{array}{r}
491.886 \\
0.000 \\
0.000 \\
491.886 \\
1927.989
\end{array}
$$

96.030

1.580

1. 129

0.000

19.920

0.190

0.000

1928.319
442.083

0.000

0.000

442.083

1812.215

90.507

1.517

1.103

0.000

19.888

0.188

0.000

1812.669
544.472

0.000

0.000

544.472

2049.508

101.378

1.634

1.151

0.000

19.956

0.192

0.000

2050.337

Contact status codes:

$0=$ open/no heat transfer, 1 =near-field contact

2=closed and sliding, $3=$ closed and sticking

CONTACT SUMMARY FOR CONTACT ID 71: Clad2 TO Housing (Frictionless)

Contact surface material: FeCrAl

Target surface material: AL-6061

Interstitial gas: $970 \mathrm{HE} 30$

Effective surface roughness: $2 . \overline{2} 63 \mu \mathrm{m}$

Effective asperity slope: $0.214 \mathrm{rad}$

Effective microhardness: $\quad 1.220 \mathrm{GPa}$

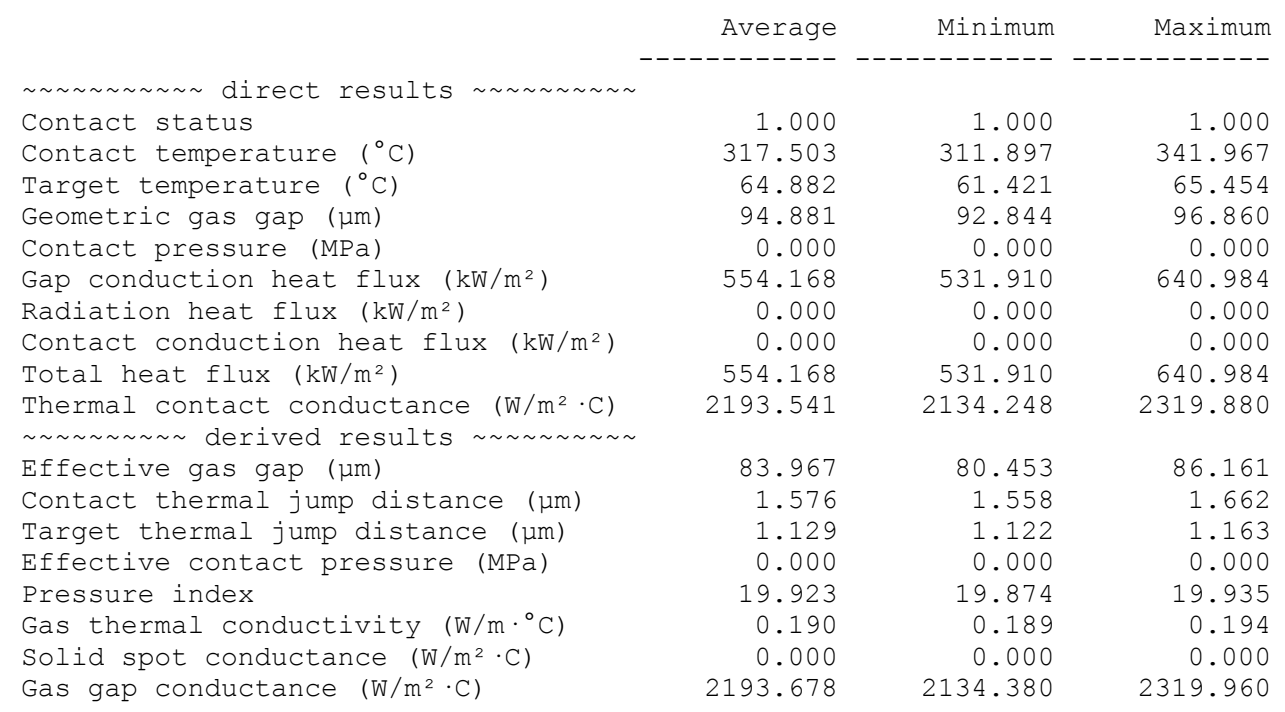

Contact status codes:

$0=$ open/no heat transfer, 1 =near-field contact

$2=$ closed and sliding, $3=c l o s e d$ and sticking 


\section{FCZ01:}

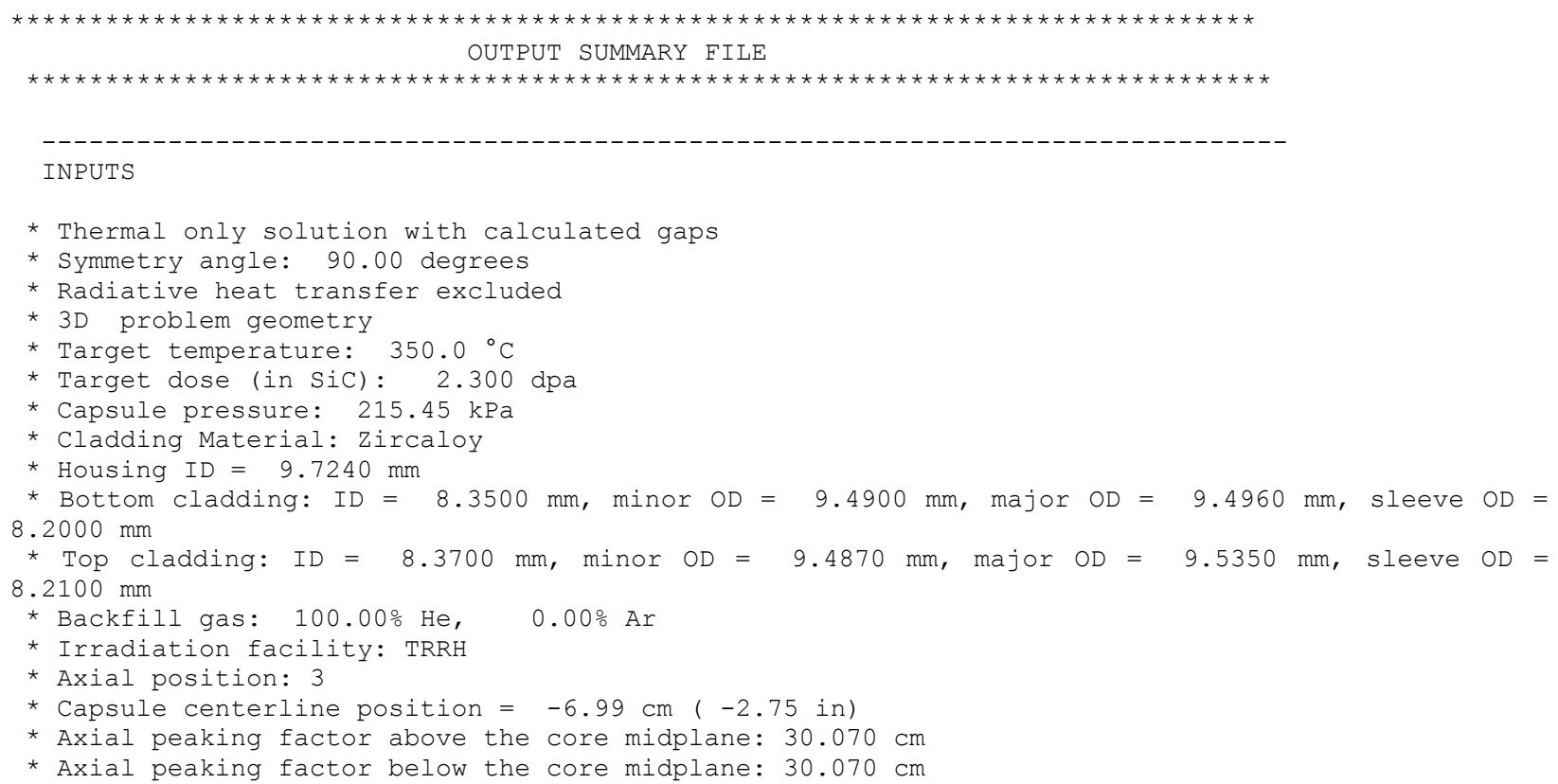

\begin{tabular}{|c|c|}
\hline $\begin{array}{c}\text { @Midplane } \\
\text { (W) }\end{array}$ & $\begin{array}{c}\text { Load ----- } \\
\text { @Location } \\
\text { (W) }\end{array}$ \\
\hline 133.0 & 125.0 \\
\hline 15.2 & 14.9 \\
\hline 0.2 & 0.2 \\
\hline 0.2 & 0.2 \\
\hline 0.3 & 0.3 \\
\hline 0.3 & 0.3 \\
\hline 7.2 & 6.5 \\
\hline 89.2 & 82.0 \\
\hline 19.7 & 18.1 \\
\hline 7.2 & 6.8 \\
\hline 227.7 & 209.2 \\
\hline 19.2 & 18.1 \\
\hline 0.6 & 0.6 \\
\hline 7.2 & 6.8 \\
\hline 91.0 & 87.4 \\
\hline 21.5 & 20.7 \\
\hline 7.2 & 7.0 \\
\hline 228.9 & 219.7 \\
\hline 19.3 & 18.8 \\
\hline 0.6 & 0.6 \\
\hline 0.7 & 0.6 \\
\hline 0.7 & 0.6 \\
\hline 0.7 & 0.6 \\
\hline 0.7 & 0.6 \\
\hline 0.2 & 0.2 \\
\hline 0.2 & 0.2 \\
\hline 0.2 & 0.2 \\
\hline
\end{tabular}




\begin{tabular}{|c|c|c|c|c|c|}
\hline 32) & Grafoil8 & GRAFOIL & 33700 . & 0.3 & 0.3 \\
\hline 33) & Grafoilg & GRAFOIL & 33700 . & 0.3 & 0.3 \\
\hline 34) & Grafoillo & GRAFOIL & 33700 . & 0.3 & 0.3 \\
\hline & & --1 & $--0-$ & & \\
\hline
\end{tabular}

CAPSULE TEMPERATURE SUMMARY

\begin{tabular}{|c|c|c|c|c|c|c|c|}
\hline Name & & Material & Tavg & Tmin & Tmax & T.025 & T. 975 \\
\hline 1) & Housing & $A L-6061$ & 62. & 54. & 78. & 54. & 75. \\
\hline 2) & Cap & $A L-6061$ & 82. & 80 . & 83. & 80. & 83. \\
\hline 3) & Grafoill & GRAFOIL & 112 . & 104. & 119. & 111. & 113. \\
\hline 4) & Grafoil2 & GRAFOIL & 153. & 146. & 161. & 152. & 154. \\
\hline 5) & Grafoil6 & GRAFOIL & 462 . & 452. & 468 & 454. & 467. \\
\hline 6) & Grafoil7 & GRAFOIL & 460 & 451. & 464 . & 453. & 463. \\
\hline 7) & Thimblela & $\mathrm{Ti}-6 \mathrm{Al} 4 \mathrm{~V}$ & 358 . & 262. & 402 . & 309 . & 400. \\
\hline 8) & Cladl & Zircaloy & 317. & 290. & 344 . & 295. & 339. \\
\hline 9) & Clad1 & Zircaloy & 311. & 288. & 332. & 290 & 329. \\
\hline 10) & Thimble1b & $\mathrm{Ti}-6 \mathrm{Al} 4 \mathrm{~V}$ & 472 . & 350. & 483. & 435. & 482. \\
\hline 11) & Sleevel & Moly & 436. & 386. & 474 . & 392. & 471. \\
\hline 13) & Sleeve1 & Moly & 476 & 472 . & 477 . & 473. & 477. \\
\hline 15) & TM1 & $\operatorname{SiC}(\operatorname{Ir} r)$ & 437. & 368. & 475. & 391. & 474. \\
\hline 16) & Thimble2a & $\mathrm{Ti}-6 \mathrm{Al} 4 \mathrm{~V}$ & 456. & 329. & 468. & 413. & 466. \\
\hline 17) & $\mathrm{Clad} 2$ & Zircaloy & 333. & 314. & 375 . & 319. & 349. \\
\hline 18) & $\mathrm{Clad} 2$ & Zircaloy & 325 . & 311. & 360. & 313. & 340. \\
\hline 19) & Thimble2b & $\mathrm{Ti}-6 \mathrm{Al} 4 \mathrm{~V}$ & 474. & 355. & 482 . & 443. & 481. \\
\hline 20) & Sleeve2 & Moly & 450 & 442 . & 472 . & 443. & 469. \\
\hline 22) & Sleeve2 & Moly & 474 & 470. & 476 & 472 . & 476. \\
\hline 24) & TM2 & $\operatorname{SiC}(\operatorname{Irr})$ & 452. & 445. & 474. & 445 . & 472. \\
\hline 25) & Wire1 & Moly & 420. & 408. & 428. & 409. & 428. \\
\hline 26) & Wire2 & Moly & 512. & 501. & 521. & 502 . & 520. \\
\hline 27) & Wire3 & Moly & 474 . & 459. & 483. & 461. & 483. \\
\hline 28) & Wire4 & Moly & 512. & 501. & 521. & 501. & 521. \\
\hline 29) & Grafoil3 & GRAFOIL & 192. & 182. & 202 . & 188. & 195. \\
\hline 30$)$ & Grafoil4 & GRAFOIL & 230 & 214. & 243. & 219. & 236. \\
\hline 31) & Grafoil5 & GRAFOIL & 267. & 237. & 286. & 239. & 277. \\
\hline 32) & Grafoil8 & GRAFOIL & 458. & 450. & 463. & 451. & 463. \\
\hline 33) & Grafoilg & GRAFOIL & 456. & 449. & 462. & 450. & 462. \\
\hline 34) & Grafoilio & GRAFOIL & 456. & 449 . & 462 . & 450 & 462 \\
\hline
\end{tabular}

PROPERTY SUMMARY AT THE AVERAGE PART TEMPERATURE

\begin{tabular}{|c|c|c|c|c|c|}
\hline \multicolumn{2}{|l|}{ Name } & \multirow{2}{*}{ Material } & $\begin{array}{l}\text { Thermal } \\
\text { Cond. } \\
\left(\mathrm{W} / \mathrm{m} \cdot{ }^{\circ} \mathrm{C}\right)\end{array}$ & $\begin{array}{l}\text { Thermal } \\
\text { Exp. } \\
\text { Coeff. } \\
\left(\mu \mathrm{m} / \mathrm{m} \cdot{ }^{\circ} \mathrm{C}\right)\end{array}$ & $\begin{array}{l}\text { Emis } \\
(---)\end{array}$ \\
\hline & -1 & & --------- & --------- & ------ \\
\hline 1) & Housing & $\mathrm{AL}-6061$ & 166.915 & 24.21 & 0.050 \\
\hline 2) & Cap & $A L-6061$ & 169.217 & 0.00 & 0.050 \\
\hline 3) & Grafoill & GRAFOIL & 38.000 & 1.00 & 0.500 \\
\hline 4) & Grafoil2 & GRAFOIL & 38.000 & 1.00 & 0.500 \\
\hline 5) & Grafoil 6 & GRAFOIL & 38.000 & 1.00 & 0.500 \\
\hline 6) & Grafoil7 & GRAFOIL & 38.000 & 1.00 & 0.500 \\
\hline 7) & Thimblela & Ti-6Al4V & 13.706 & 9.97 & 0.379 \\
\hline 8) & Cladl & Zircaloy & 16.374 & 4.83 & 0.699 \\
\hline 9) & Cladl & Zircaloy & 16.295 & 0.00 & 0.699 \\
\hline 10) & Thimble1b & $\mathrm{Ti}-6 \mathrm{Al} 4 \mathrm{~V}$ & 16.090 & 10.19 & 0.403 \\
\hline 11) & Sleeve1 & Moly & 121.651 & 5.14 & 0.071 \\
\hline 13) & Sleevel & Moly & 120.058 & 0.00 & 0.075 \\
\hline 15) & TM1 & $\operatorname{SiC}(\operatorname{Irr})$ & 8.686 & 3.63 & 0.900 \\
\hline 16) & Thimble $2 \mathrm{a}$ & Ti-6Al4V & 15.739 & 10.16 & 0.401 \\
\hline 17) & $\mathrm{Clad} 2$ & Zircaloy & 16.559 & 4.84 & 0.699 \\
\hline 18) & $\mathrm{Clad} 2$ & Zircaloy & 16.460 & 0.00 & 0.699 \\
\hline 19) & Thimble2b & Ti-6Al4V & 16.116 & 10.20 & 0.404 \\
\hline 20) & Sleeve2 & Moly & 121.085 & 5.16 & 0.072 \\
\hline 22) & Sleeve2 & Moly & 120.115 & 0.00 & 0.075 \\
\hline 24) & TM2 & $\operatorname{SiC}(\operatorname{Ir} r)$ & 8.675 & 3.66 & 0.900 \\
\hline 25) & Wire1 & Moly & 122.276 & 0.00 & 0.069 \\
\hline
\end{tabular}




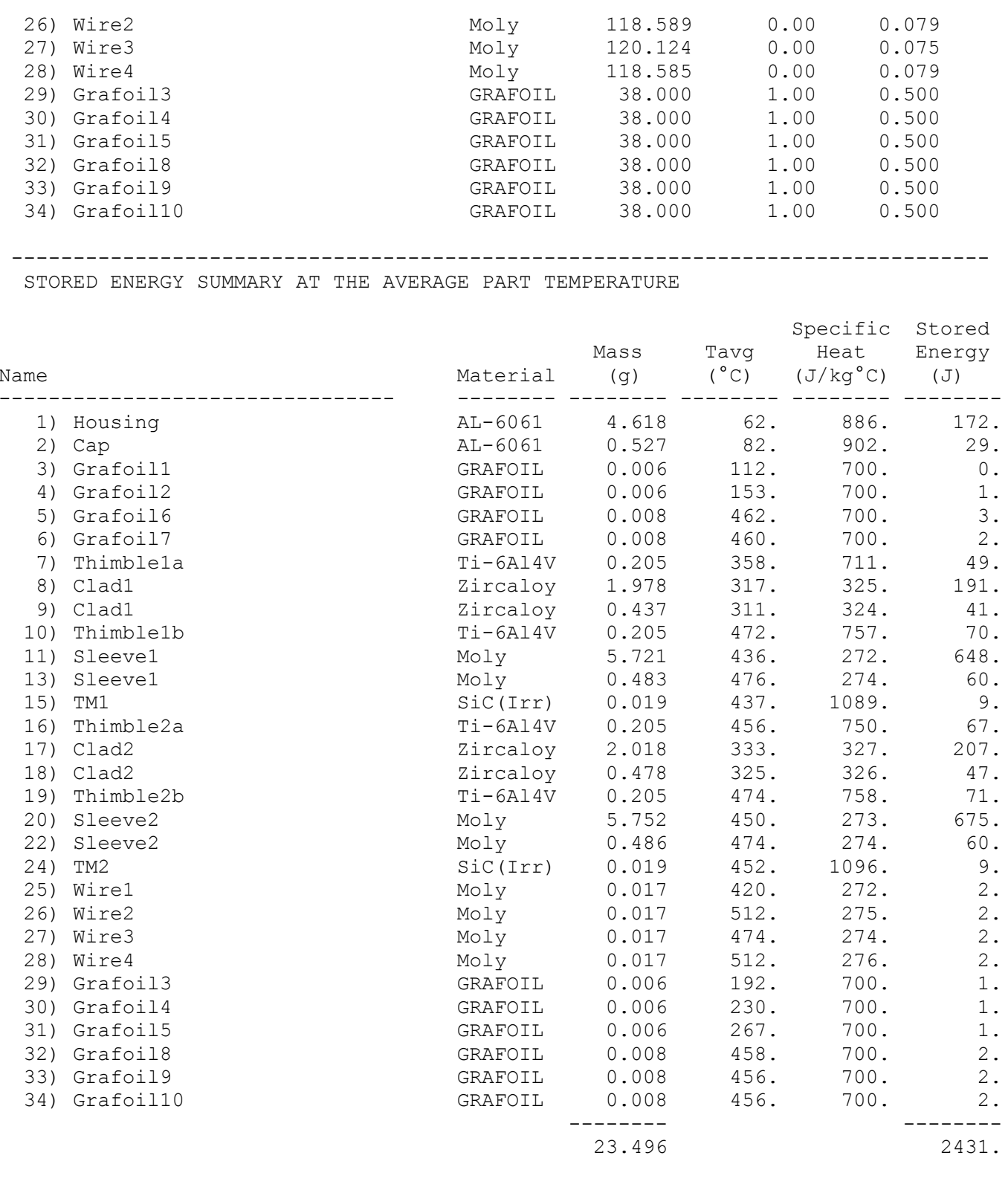

CLAD TO HOUSING GAP REPORTS

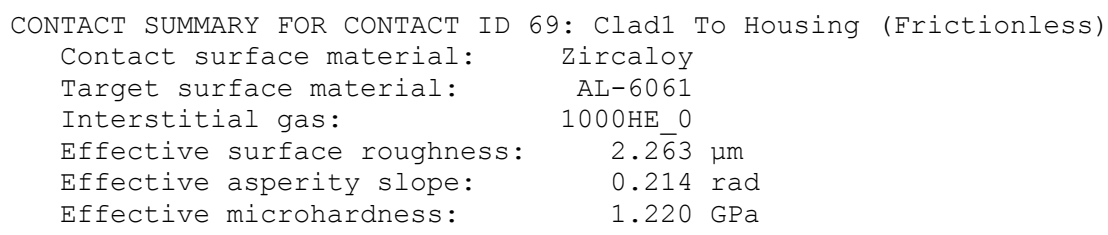


Gap conduction heat flux $\left(\mathrm{kW} / \mathrm{m}^{2}\right)$

Radiation heat flux $\left(\mathrm{kW} / \mathrm{m}^{2}\right)$

Contact conduction heat flux $\left(\mathrm{kW} / \mathrm{m}^{2}\right)$

Total heat flux $\left(\mathrm{kW} / \mathrm{m}^{2}\right)$

Thermal contact conductance $\left(\mathrm{W} / \mathrm{m}^{2} \cdot \mathrm{C}\right)$

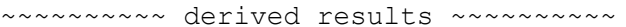

Effective gas gap ( $\mathrm{m}$ )

Contact thermal jump distance ( $\mu \mathrm{m})$

Target thermal jump distance ( $\mu m)$

Effective contact pressure (MPa)

Pressure index

Gas thermal conductivity $\left(\mathrm{W} / \mathrm{m} \cdot{ }^{\circ} \mathrm{C}\right)$

Solid spot conductance $\left(\mathrm{W} / \mathrm{m}^{2} \cdot \mathrm{C}\right)$

Gas gap conductance $\left(W / \mathrm{m}^{2} \cdot \mathrm{C}\right)$
433.710

0.000

0.000

433.710

1756.652

$$
\begin{array}{r}
113.627 \\
2.061 \\
1.289 \\
0.000 \\
15.350 \\
0.206 \\
0.000
\end{array}
$$

1758.283
386.134

0.000

0.000

386.134

1703.611

$$
\begin{array}{r}
111.453 \\
1.940 \\
1.253 \\
0.000 \\
15.258 \\
0.202 \\
0.000 \\
1705.130
\end{array}
$$

482.203

0.000

0.000

482.203

1809.964

115.662

2.168

1. 320

0.000

\begin{tabular}{|c|c|c|c|}
\hline & Average & Minimum & Maximum \\
\hline$u \sim$ & --- & - & \\
\hline Contact status & 1.000 & 1.000 & 1.000 \\
\hline Contact temperature $\left({ }^{\circ} \mathrm{C}\right)$ & 323.411 & 310.737 & 353.886 \\
\hline Target temperature $\left({ }^{\circ} \mathrm{C}\right)$ & 63.779 & 60.510 & 64.866 \\
\hline Geometric gas gap ( $\mu \mathrm{m})$ & 106.388 & 94.371 & 118.302 \\
\hline Contact pressure (MPa) & 0.000 & 0.000 & 0.000 \\
\hline Gap conduction heat flux $\left(\mathrm{kW} / \mathrm{m}^{2}\right)$ & 502.298 & 458.135 & 613.172 \\
\hline Radiation heat flux $\left(\mathrm{kW} / \mathrm{m}^{2}\right)$ & 0.000 & 0.000 & 0.000 \\
\hline Contact conduction heat flux $\left(\mathrm{kW} / \mathrm{m}^{2}\right)$ & 0.000 & 0.000 & 0.000 \\
\hline Total heat flux $\left(\mathrm{kW} / \mathrm{m}^{2}\right)$ & 502.298 & 458.135 & 613.172 \\
\hline $\begin{array}{l}\text { Thermal contact conductance }\left(\mathrm{W} / \mathrm{m}^{2} \cdot \mathrm{C}\right) \\
\sim \sim \sim \sim \sim \sim \sim \sim \sim \text { derived results } \sim \sim \sim \sim \sim \sim \sim \sim\end{array}$ & 1937.813 & 1740.579 & 2205.069 \\
\hline Effective gas gap ( $\mu \mathrm{m})$ & 104.433 & 91.953 & 116.237 \\
\hline Contact thermal jump distance ( $\mu \mathrm{m})$ & 2.144 & 2.074 & 2.322 \\
\hline Target thermal jump distance ( $\mu \mathrm{m})$ & 1.316 & 1.297 & 1.366 \\
\hline Effective contact pressure (MPa) & 0.000 & 0.000 & 0.000 \\
\hline Pressure index & 15.284 & 15.137 & 15.344 \\
\hline Gas thermal conductivity $\left(\mathrm{W} / \mathrm{m} \cdot{ }^{\circ} \mathrm{C}\right)$ & 0.208 & 0.206 & 0.213 \\
\hline Solid spot conductance $\left(\mathrm{W} / \mathrm{m}^{2} \cdot \mathrm{C}\right)$ & 0.000 & 0.000 & 0.000 \\
\hline Gas gap conductance $\left(\mathrm{W} / \mathrm{m}^{2} \cdot \mathrm{C}\right)$ & 1939.733 & 1742.407 & 2208.138 \\
\hline
\end{tabular}

15.452

0.209

0.000

1812.209

Contact status codes:

$0=$ open/no heat transfer, 1 =near-field contact

$2=$ closed and sliding, $3=$ closed and sticking

CONTACT SUMMARY FOR CONTACT ID 71: Clad2 TO Housing (Frictionless)

Contact surface material: Zircaloy

Target surface material: AL-6061

Interstitial gas:

Effective surface roughness: $2.2 \overline{6} 3 \mu \mathrm{m}$

Effective asperity slope: $0.214 \mathrm{rad}$

Effective microhardness: $\quad 1.220 \mathrm{GPa}$

Contact status codes:

$0=$ open/no heat transfer, 1 =near-field contact

$2=$ closed and sliding, $3=$ closed and sticking 


\section{FCZ02:}

OUTPUT SUMMARY FILE

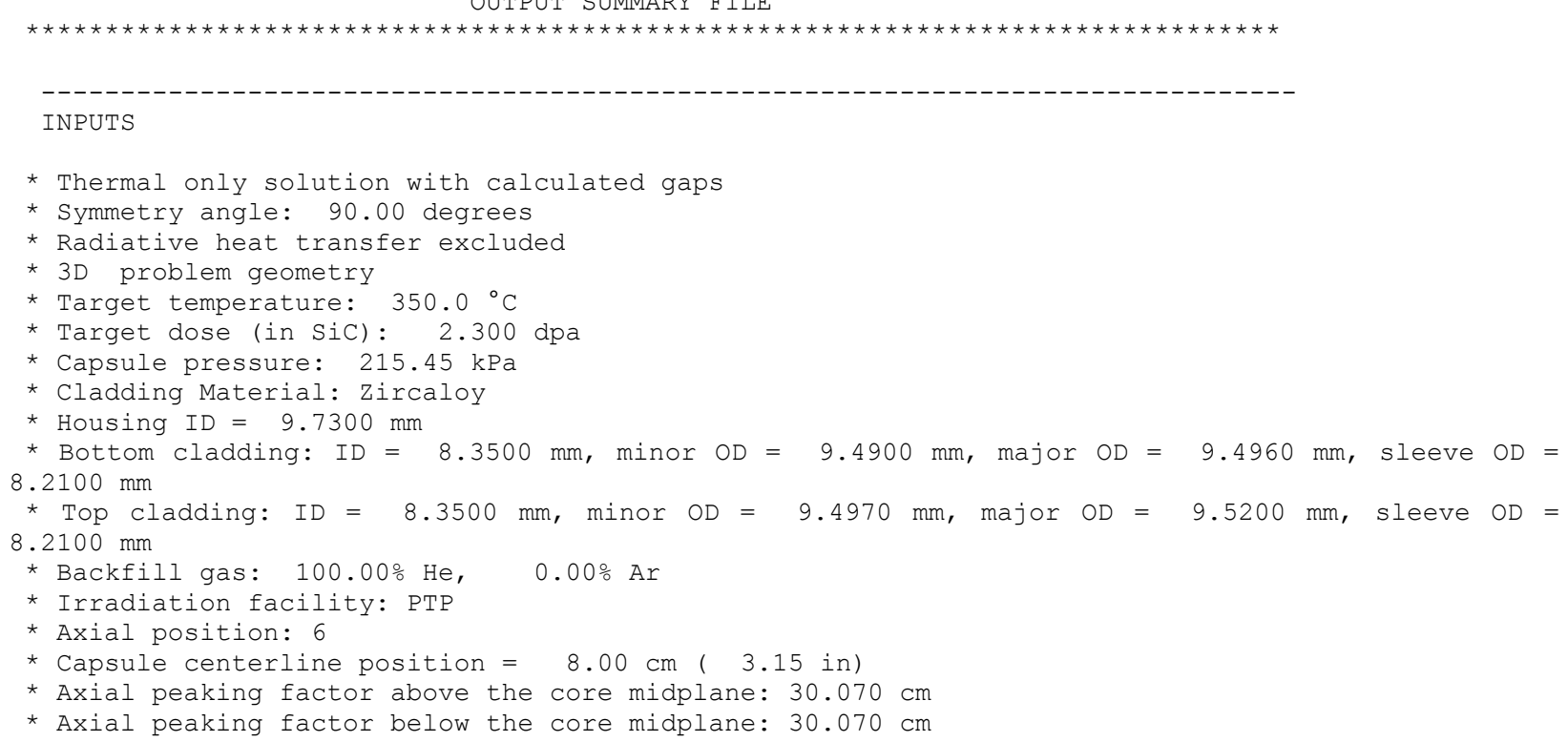

$\begin{array}{ll}\text { Part } \\ \text { 1) } & \text { Housing } \\ \text { 2) } & \text { Cap } \\ \text { 3) } & \text { Grafoil1 } \\ \text { 4) } & \text { Grafoild } \\ \text { 5) } & \text { Grafoil6 } \\ \text { 6) } & \text { Grafoil7 } \\ \text { 7) } & \text { Thimblela } \\ \text { 8) } & \text { Clad1 } \\ \text { 9) } & \text { Clad1 } \\ \text { 10) } & \text { Thimble1b } \\ \text { 11) } & \text { Sleeve1 } \\ \text { 13) } & \text { Sleeve1 } \\ \text { 15) } & \text { TM1 } \\ \text { 16) } & \text { Thimble2a } \\ \text { 17) } & \text { Clad2 } \\ \text { 18) } & \text { Clad2 } \\ \text { 19) } & \text { Thimble2b } \\ \text { 20) } & \text { Sleeve2 } \\ \text { 22) } & \text { Sleeve2 } \\ \text { 24) } & \text { TM2 } \\ \text { 25) } & \text { Wire1 } \\ \text { 26) } & \text { Wire2 } \\ \text { 27) } & \text { Wire3 } \\ \text { 28) } & \text { Wire4 } \\ \text { 29) } & \text { Grafoil3 } \\ \text { 30) } & \text { Grafoil4 } \\ \text { 31) } & \text { Grafoil5 } \\ & \end{array}$

\begin{tabular}{|c|c|}
\hline Material & $(\mathrm{W} / \mathrm{kg})$ \\
\hline$A L-6061$ & 2990 \\
\hline $\mathrm{AL}-6061$ & 2990 \\
\hline GRAFOIL & 3500 \\
\hline GRAFOIL & 3500 \\
\hline GRAFOIL & 350 \\
\hline GRAFOIL & 350 \\
\hline $\mathrm{Ti}-6 \mathrm{~A} l 4 \mathrm{~V}$ & 356 \\
\hline Zircaloy & 461 \\
\hline Zircaloy & 4610 \\
\hline Ti-6Al4V & $356 c$ \\
\hline Moly & 410 \\
\hline Moly & 410 \\
\hline $\operatorname{SiC}(\operatorname{Irr})$ & 340 \\
\hline Ti-6Al4V & 356 \\
\hline Zircaloy & 461 \\
\hline Zircaloy & 461 \\
\hline $\mathrm{Ti}-6 \mathrm{Al} 4 \mathrm{~V}$ & 356 \\
\hline Moly & 4100 \\
\hline Moly & 410 \\
\hline $\operatorname{SiC}(\operatorname{Irr})$ & 340 \\
\hline Moly & 410 \\
\hline Moly & 410 \\
\hline Moly & 410 \\
\hline Moly & 410 \\
\hline GRAFOIL & 350 \\
\hline GRAFOIL & 350 \\
\hline GRAFOIL & 350 \\
\hline
\end{tabular}

\begin{tabular}{|c|c|}
\hline $\begin{array}{l}\text { aMidplane } \\
\text { (W) }\end{array}$ & $\begin{array}{c}\text { @Location } \\
\text { (W) }\end{array}$ \\
\hline 137.6 & 128.4 \\
\hline 15.8 & 13.8 \\
\hline 0.2 & 0.2 \\
\hline 0.2 & 0.2 \\
\hline 0.3 & 0.3 \\
\hline 0.3 & 0.3 \\
\hline 7.3 & 7.1 \\
\hline 93.0 & 89.1 \\
\hline 20.1 & 19.3 \\
\hline 7.3 & 6.9 \\
\hline 235.8 & 225.7 \\
\hline 19.9 & 18.7 \\
\hline 0.7 & 0.6 \\
\hline 7.3 & 6.8 \\
\hline 93.0 & 85.2 \\
\hline 21.8 & 19.9 \\
\hline 7.3 & 6.5 \\
\hline 235.8 & 215.8 \\
\hline 19.9 & 17.8 \\
\hline 0.7 & 0.6 \\
\hline 0.7 & 0.7 \\
\hline 0.7 & 0.6 \\
\hline 0.7 & 0.6 \\
\hline 0.7 & 0.6 \\
\hline 0.2 & 0.2 \\
\hline 0.2 & 0.2 \\
\hline 0.2 & 0.2 \\
\hline
\end{tabular}




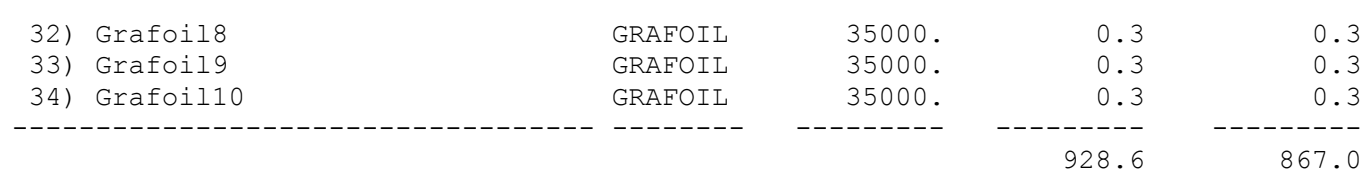

CAPSULE TEMPERATURE SUMMARY

\begin{tabular}{|c|c|c|c|c|c|c|c|}
\hline \multicolumn{2}{|l|}{ Name } & Material & Tavg & Tmin & Tmax & T.025 & T.975 \\
\hline & Housing & $\begin{array}{l}-------- \\
A T-6061\end{array}$ & $\begin{array}{c}----- \\
64\end{array}$ & ----- & ----- & $\begin{array}{c}----- \\
56\end{array}$ & $\begin{array}{c}----- \\
79\end{array}$ \\
\hline $\begin{array}{l}\text { 1) } \\
\text { 2) }\end{array}$ & $\begin{array}{l}\text { Housing } \\
\text { Cap }\end{array}$ & $\begin{array}{l}\mathrm{AL}-6061 \\
\mathrm{AL}-6061\end{array}$ & $\begin{array}{l}64 . \\
81 .\end{array}$ & $\begin{array}{l}56 . \\
80 .\end{array}$ & $\begin{array}{l}82 . \\
83 .\end{array}$ & $\begin{array}{l}56 . \\
80 .\end{array}$ & $\begin{array}{l}79 . \\
83 .\end{array}$ \\
\hline 3) & Grafoill & GRAFOIL & 118. & 109. & 125. & 116. & 119. \\
\hline 4) & Grafoil2 & GRAFOIL & 161. & 153. & 169. & 159. & 162. \\
\hline 5) & Grafoil6 & GRAFOIL & 459. & 449. & 464. & 451. & 463. \\
\hline 6) & Grafoil7 & GRAFOIL & 456. & 448. & 460. & 450 & 460. \\
\hline 7) & Thimblela & $\mathrm{Ti}-6 \mathrm{Al} 4 \mathrm{~V}$ & 374. & 283. & 419. & 327. & 417. \\
\hline 8) & Clad1 & Zircaloy & 342 . & 315. & 367. & 320. & 362. \\
\hline 9) & Clad1 & Zircaloy & 335. & 312. & 354. & 315. & 351. \\
\hline 10) & Thimblelb & Ti-6Al4V & 482 . & 370. & 492. & 447 . & 491. \\
\hline 11) & Sleevel & Moly & 448. & 403. & 483. & 409. & 480. \\
\hline 13) & Sleevel & Moly & 485. & 481. & 486. & 482. & 486. \\
\hline 15) & TM1 & $\operatorname{SiC}(\operatorname{Irr})$ & 450. & 384. & 484. & 407 . & 483. \\
\hline 16) & Thimble2a & $\mathrm{Ti}-6 \mathrm{Al} 4 \mathrm{~V}$ & 465. & 347. & 477. & 424. & 475 . \\
\hline 17) & $\mathrm{Clad} 2$ & Zircaloy & 338. & 325. & 383. & 329. & 351. \\
\hline 18) & $\mathrm{Clad} 2$ & Zircaloy & 330. & 322. & 368. & 324. & 342. \\
\hline 19) & Thimble2b & $\mathrm{Ti}-6 \mathrm{Al} 4 \mathrm{~V}$ & 470. & 365. & 478. & 442 . & 477. \\
\hline 20) & Sleeve2 & Moly & 453. & 446. & 469. & 447 . & 466. \\
\hline 22) & Sleeve2 & Moly & 470. & 466. & 472 . & 468. & 472. \\
\hline 24) & TM2 & $\operatorname{SiC}(\operatorname{Irr})$ & 455. & 449. & 470 . & 449. & 468. \\
\hline 25) & Wire1 & Moly & 439. & 425. & 447. & 426. & 447. \\
\hline 26) & Wire2 & Moly & 522. & 511. & 531. & 511. & 531. \\
\hline 27) & Wire3 & Moly & 483. & 469. & 492. & 470 & 492. \\
\hline 28) & Wire4 & Moly & 506. & 496. & 514. & 496. & 514. \\
\hline 29) & Grafoil3 & GRAFOIL & 202. & 191. & 212. & 197. & 205. \\
\hline 30) & Grafoil4 & GRAFOIL & 241. & 224. & 255. & 229. & 248. \\
\hline 31) & Grafoil5 & GRAFOIL & 280. & 248. & 301. & 251. & 291. \\
\hline 32) & Grafoil8 & GRAFOIL & 454. & 447. & 459. & 448 & 459. \\
\hline 33) & Grafoil9 & GRAFOIL & 453. & 446. & 458. & 447 . & 458. \\
\hline 34) & Grafoillo & GRAFOIL & 452. & 445. & 458. & 446. & 458. \\
\hline
\end{tabular}

PROPERTY SUMMARY AT THE AVERAGE PART TEMPERATURE

\begin{tabular}{|c|c|c|c|c|c|}
\hline Name & & Material & $\begin{array}{l}\text { Thermal } \\
\text { Cond. } \\
\left(\mathrm{W} / \mathrm{m} \cdot{ }^{\circ} \mathrm{C}\right)\end{array}$ & $\begin{array}{l}\text { Thermal } \\
\text { Exp. } \\
\text { Coeff. } \\
\left(\mu \mathrm{m} / \mathrm{m} \cdot{ }^{\circ} \mathrm{C}\right)\end{array}$ & $\begin{array}{l}\text { Emis } \\
(---)\end{array}$ \\
\hline & & & 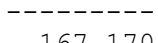 & ----- & ------ \\
\hline $\begin{array}{l}\text { 1) } \\
\text { 2) }\end{array}$ & $\begin{array}{l}\text { Housing } \\
\text { Cap }\end{array}$ & $\begin{array}{l}A L-6061 \\
A L-6061\end{array}$ & $\begin{array}{l}16 \% .170 \\
169.183\end{array}$ & $\begin{array}{r}24.21 \\
0.00\end{array}$ & $\begin{array}{l}0.050 \\
0.050\end{array}$ \\
\hline 3) & Grafoill & GRAFOIL & 38.000 & 1.00 & 0.500 \\
\hline 4) & Grafoil2 & GRAFOIL & 38.000 & 1.00 & 0.500 \\
\hline 5) & Grafoil 6 & GRAFOIL & 38.000 & 1.00 & 0.500 \\
\hline 6) & Grafoil7 & GRAFOIL & 38.000 & 1.00 & 0.500 \\
\hline 7) & Thimblela & Ti-6Al4V & 14.055 & 10.00 & 0.385 \\
\hline 8) & Cladl & Zircaloy & 16.664 & 4.84 & 0.699 \\
\hline 9) & Clad1 & Zircaloy & 16.578 & 0.00 & 0.699 \\
\hline 10) & Thimble1b & $\mathrm{Ti}-6 \mathrm{Al} 4 \mathrm{~V}$ & 16.293 & 10.21 & 0.404 \\
\hline 11) & Sleevel & Moly & 121.145 & 5.15 & 0.072 \\
\hline 13) & Sleevel & Moly & 119.697 & 0.00 & 0.076 \\
\hline 15) & TM1 & $\operatorname{SiC}(\operatorname{Irr})$ & 8.676 & 3.66 & 0.900 \\
\hline 16) & Thimble2a & Ti-6Al4V & 15.927 & 10.18 & 0.403 \\
\hline 17) & $\mathrm{Clad} 2$ & Zircaloy & 16.622 & 4.84 & 0.699 \\
\hline 18) & $\mathrm{Clad} 2$ & Zircaloy & 16.529 & 0.00 & 0.699 \\
\hline 19) & Thimble2b & $\mathrm{Ti}-6 \mathrm{Al} 4 \mathrm{~V}$ & 16.033 & 10.19 & 0.403 \\
\hline 20) & Sleeve2 & Moly & 120.975 & 5.16 & 0.072 \\
\hline 22) & Sleeve2 & Moly & 120.266 & 0.00 & 0.074 \\
\hline 24) & TM2 & $\operatorname{SiC}(\operatorname{Irr})$ & 8.673 & 3.67 & 0.900 \\
\hline 25) & Wire1 & Moly & 121.534 & 0.00 & 0.071 \\
\hline
\end{tabular}




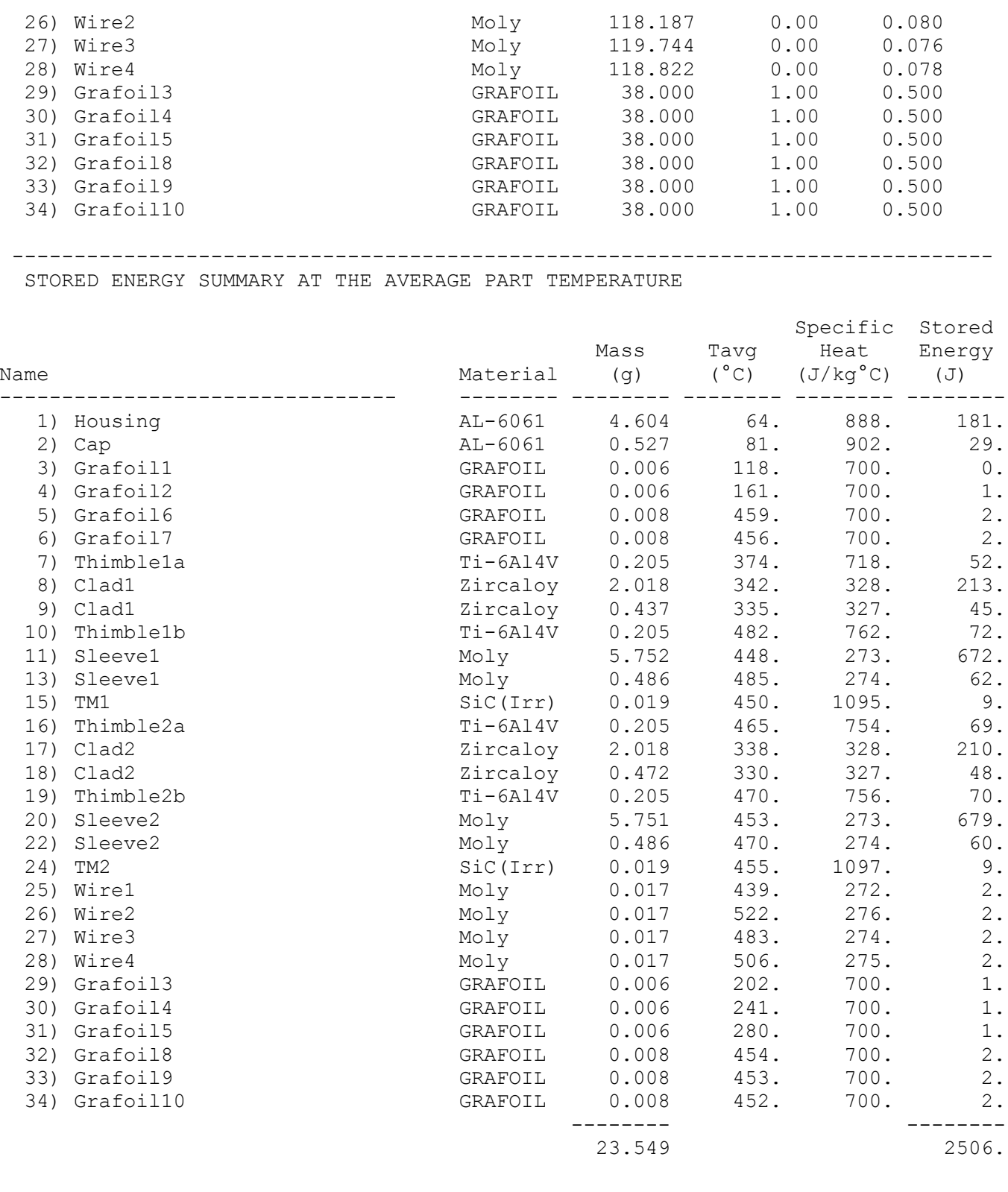

CLAD TO HOUSING GAP REPORTS

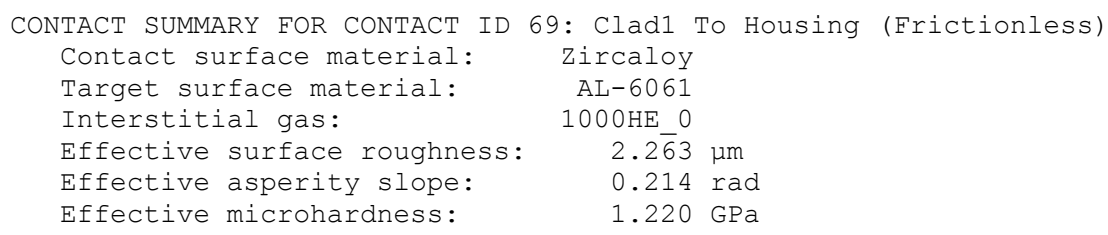


Gap conduction heat flux $\left(\mathrm{kW} / \mathrm{m}^{2}\right)$

Radiation heat flux $\left(\mathrm{kW} / \mathrm{m}^{2}\right)$

Contact conduction heat flux $\left(\mathrm{kW} / \mathrm{m}^{2}\right)$

Total heat flux $\left(\mathrm{kW} / \mathrm{m}^{2}\right)$

Thermal contact conductance $\left(\mathrm{W} / \mathrm{m}^{2} \cdot \mathrm{C}\right)$

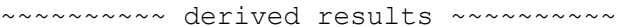

Effective gas gap ( $\mu \mathrm{m})$

Contact thermal jump distance ( $\mu \mathrm{m})$

Target thermal jump distance ( $\mu m)$

Effective contact pressure (MPa)

Pressure index

Gas thermal conductivity $\left(\mathrm{W} / \mathrm{m} \cdot{ }^{\circ} \mathrm{C}\right)$

Solid spot conductance $\left(\mathrm{W} / \mathrm{m}^{2} \cdot \mathrm{C}\right)$

Gas gap conductance $\left(W / \mathrm{m}^{2} \cdot \mathrm{C}\right)$

$$
\begin{array}{r}
469.077 \\
0.000 \\
0.000 \\
469.077 \\
1749.140
\end{array}
$$
116.356
2.206
1. 337
0.000
15.236
0.210
0.000

1750.664
419.101

0.000

0.000

419.101

1697.165

114.181

2.089

1.303

0.000

15.152

0.207

0.000

1698.304
514.598

0.000

0.000

514.598

1797.905

118.427

2.305

1.364

0.000

15.333

0.212

0.000

1800.095

Contact status codes:

$0=$ open/no heat transfer, 1 =near-field contact

2=closed and sliding, $3=$ closed and sticking

CONTACT SUMMARY FOR CONTACT ID 71: Clad2 TO Housing (Frictionless)

Contact surface material: Zircaloy

Target surface material: AL-6061

\begin{tabular}{|c|c|c|c|}
\hline \multirow{3}{*}{ 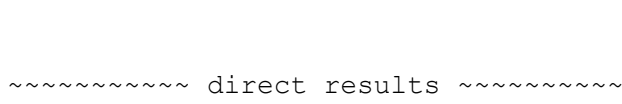 } & Average & Minimum & Maximum \\
\hline & -------- & & \\
\hline & & & \\
\hline Contact status & 1.000 & 1.000 & 1.000 \\
\hline Contact temperature $\left({ }^{\circ} \mathrm{C}\right)$ & 329.019 & 321.728 & 361.023 \\
\hline Target temperature $\left({ }^{\circ} \mathrm{C}\right)$ & 65.285 & 62.107 & 65.935 \\
\hline Geometric gas gap ( $\mu \mathrm{m})$ & 110.632 & 104.853 & 116.320 \\
\hline Contact pressure (MPa) & 0.000 & 0.000 & 0.000 \\
\hline Gap conduction heat flux $\left(\mathrm{kW} / \mathrm{m}^{2}\right)$ & 491.693 & 466.932 & 585.924 \\
\hline Radiation heat flux $\left(\mathrm{kW} / \mathrm{m}^{2}\right)$ & 0.000 & 0.000 & 0.000 \\
\hline Contact conduction heat flux $\left(\mathrm{kW} / \mathrm{m}^{2}\right)$ & 0.000 & 0.000 & 0.000 \\
\hline Total heat flux $\left(\mathrm{kW} / \mathrm{m}^{2}\right)$ & 491.693 & 466.932 & 585.924 \\
\hline Thermal contact conductance $\left(\mathrm{W} / \mathrm{m}^{2} \cdot \mathrm{C}\right)$ & 1864.858 & 1772.422 & 2012.112 \\
\hline $\begin{array}{l}\sim \sim \sim \sim \sim \sim \sim \sim \text { derived results } \\
\text { Effective gas gap ( } \mu \mathrm{m})\end{array}$ & 108.718 & 102.256 & 114.418 \\
\hline Contact thermal jump distance ( $\mu \mathrm{m})$ & 2.181 & 2.140 & 2.371 \\
\hline Target thermal jump distance ( $\mu \mathrm{m})$ & 1.330 & 1.319 & 1.383 \\
\hline Effective contact pressure (MPa) & 0.000 & 0.000 & 0.000 \\
\hline Pressure index & 15.257 & 15.102 & 15.292 \\
\hline Gas thermal conductivity $\left(\mathrm{W} / \mathrm{m} \cdot{ }^{\circ} \mathrm{C}\right)$ & 0.209 & 0.208 & 0.214 \\
\hline Solid spot conductance $\left(\mathrm{W} / \mathrm{m}^{2} \cdot \mathrm{C}\right)$ & 0.000 & 0.000 & 0.000 \\
\hline Gas gap conductance $\left(\mathrm{W} / \mathrm{m}^{2} \cdot \mathrm{C}\right)$ & 1866.672 & 1774.110 & 2014.245 \\
\hline
\end{tabular}

Interstitial gas: $1000 \mathrm{HE} 0$

Effective surface roughness: $2.2 \overline{6} 3 \mu \mathrm{m}$

Effective asperity slope: $0.214 \mathrm{rad}$

Effective microhardness: $\quad 1.220 \mathrm{GPa}$

Contact status codes:

$0=$ open/no heat transfer, 1 =near-field contact

$2=$ closed and sliding, $3=c l o s e d$ and sticking 


\section{FCZ03:}

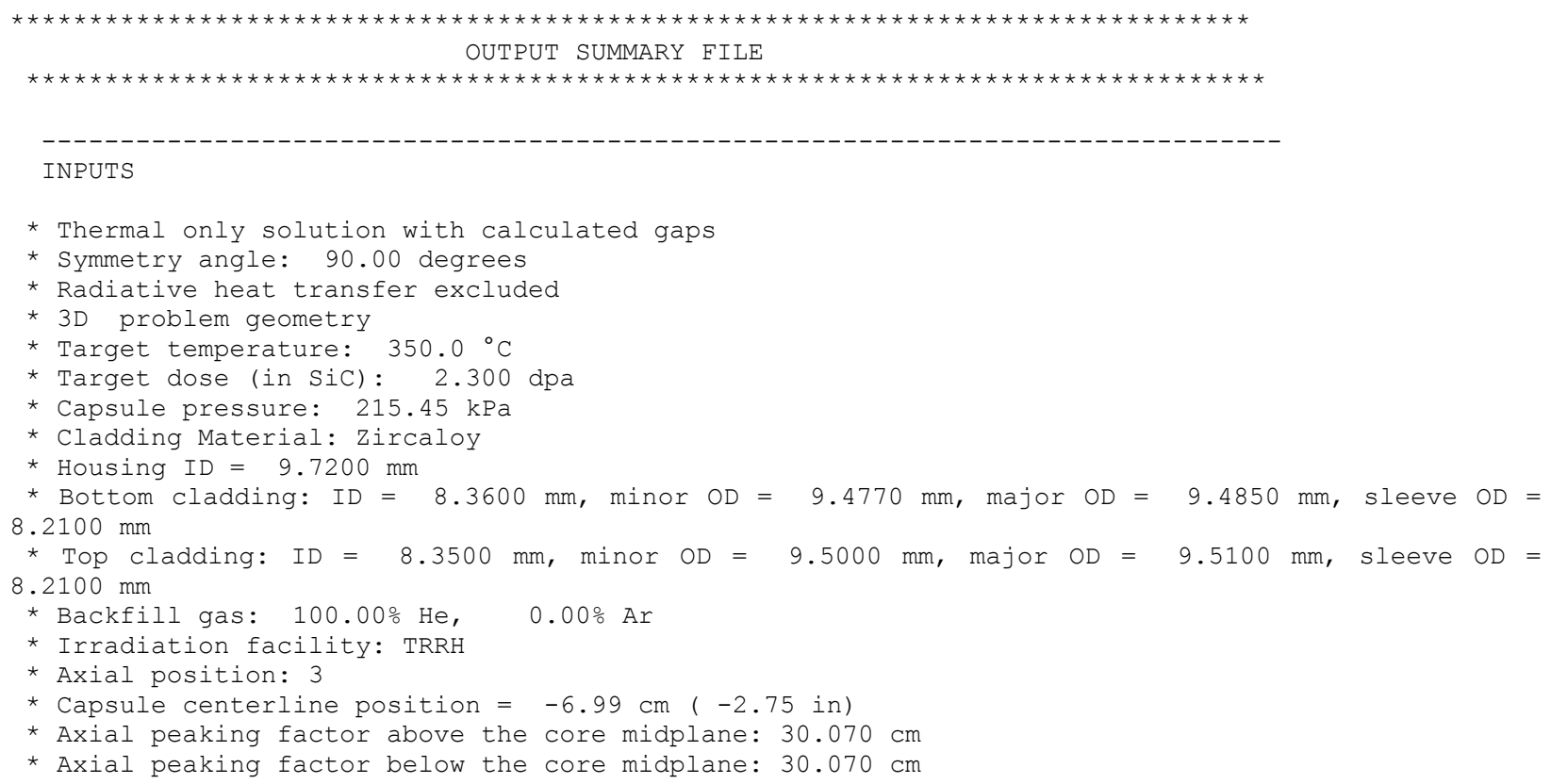

\begin{tabular}{|c|c|}
\hline $\begin{array}{l}\text { @idplane } \\
\text { (W) }\end{array}$ & $\begin{array}{c}\text { ¿Location } \\
\text { (W) }\end{array}$ \\
\hline 133.3 & 125.3 \\
\hline 15.2 & 14.9 \\
\hline 0.2 & 0.2 \\
\hline 0.2 & 0.2 \\
\hline 0.3 & 0.3 \\
\hline 0.3 & 0.3 \\
\hline 7.2 & 6.5 \\
\hline 91.0 & 83.6 \\
\hline 18.5 & 17.0 \\
\hline 7.2 & 6.8 \\
\hline 229.0 & 210.4 \\
\hline 19.3 & 18.2 \\
\hline 0.6 & 0.6 \\
\hline 7.2 & 6.8 \\
\hline 90.1 & 86.5 \\
\hline 20.9 & 20.1 \\
\hline 7.2 & 7.0 \\
\hline 228.9 & 219.7 \\
\hline 19.3 & 18.8 \\
\hline 0.6 & 0.6 \\
\hline 0.7 & 0.6 \\
\hline 0.7 & 0.6 \\
\hline 0.7 & 0.6 \\
\hline 0.7 & 0.6 \\
\hline 0.2 & 0.2 \\
\hline 0.2 & 0.2 \\
\hline 0.2 & 0.2 \\
\hline
\end{tabular}




\begin{tabular}{|c|c|c|c|c|c|}
\hline 32) & Grafoil8 & GRAFOIL & 33700 . & 0.3 & 0.3 \\
\hline 33) & Grafoilg & GRAFOIL & 33700 . & 0.3 & 0.3 \\
\hline 34) & Grafoillo & GRAFOIL & 33700 . & 0.3 & 0.3 \\
\hline & & ---1 & -1 & 00.8 & \\
\hline
\end{tabular}

CAPSULE TEMPERATURE SUMMARY

\begin{tabular}{|c|c|c|c|c|c|c|c|}
\hline \multicolumn{2}{|l|}{ Name } & Material & Tavg & Tmin & Tmax & T.025 & T.975 \\
\hline & Housing & $\begin{array}{l}-------- \\
\mathrm{AT}-6061\end{array}$ & $\begin{array}{c}----- \\
62\end{array}$ & ----- & ----- & $\begin{array}{c}----- \\
54\end{array}$ & $\begin{array}{c}----- \\
75\end{array}$ \\
\hline $\begin{array}{l}\text { 1) } \\
\text { 2) }\end{array}$ & Cap & $\begin{array}{l}\mathrm{AL}-6061 \\
\mathrm{AL}-6061\end{array}$ & $\begin{array}{l}62 . \\
82 .\end{array}$ & $\begin{array}{l}54 . \\
80 .\end{array}$ & $\begin{array}{l}78 . \\
83 .\end{array}$ & $\begin{array}{l}54 . \\
80 .\end{array}$ & $\begin{array}{l}75 . \\
83 .\end{array}$ \\
\hline 3) & Grafoill & GRAFOIL & 112. & 103. & 118. & 110. & 112. \\
\hline 4) & Grafoil2 & GRAFOIL & 152. & 145. & 159. & 150. & 153. \\
\hline 5) & Grafoil6 & GRAFOIL & 468. & 457. & 474. & 459. & 473. \\
\hline 6) & Grafoil7 & GRAFOIL & 465. & 457. & 469. & 458. & 469. \\
\hline 7) & Thimblela & $\mathrm{Ti}-6 \mathrm{Al} 4 \mathrm{~V}$ & 352. & 258. & 395. & 307. & 394. \\
\hline 8) & Clad1 & Zircaloy & 327. & 296. & 356. & 301. & 351. \\
\hline 9) & Cladl & Zircaloy & 320. & 293. & 343. & 297. & 341. \\
\hline 10) & Thimblelb & $\mathrm{Ti}-6 \mathrm{Al} 4 \mathrm{~V}$ & 468. & 340. & 477. & 432. & 477. \\
\hline 11) & Sleevel & Moly & 428. & 380. & 468. & 386. & 465. \\
\hline 13) & Sleevel & Moly & 470. & 466. & 472. & 467. & 471. \\
\hline 15) & TM1 & $\operatorname{SiC}(\operatorname{Irr})$ & 430. & 362. & 469. & 384 . & 468. \\
\hline 16) & Thimble2a & $\mathrm{Ti}-6 \mathrm{Al} 4 \mathrm{~V}$ & 458. & 324. & 468. & 412. & 467. \\
\hline 17) & $\mathrm{Clad} 2$ & Zircaloy & 334. & 321. & 371. & 325. & 346. \\
\hline 18) & $\mathrm{Clad} 2$ & Zircaloy & 326. & 318. & 355. & 320. & 335. \\
\hline 19) & Thimble2b & $\mathrm{Ti}-6 \mathrm{Al} 4 \mathrm{~V}$ & 480. & 353. & 489. & 448. & 488. \\
\hline 20) & Sleeve2 & Moly & 456. & 448 . & 479. & 449. & 476. \\
\hline 22) & Sleeve2 & Moly & 481. & 476. & 483. & 478. & 482 . \\
\hline 24) & TM2 & $\operatorname{SiC}(\operatorname{Irr})$ & 458. & 451. & 480 . & 451. & 479. \\
\hline 25) & Wire1 & Moly & 412. & 400. & 420. & 401. & 420. \\
\hline 26) & Wire2 & Moly & 507. & 496. & 515. & 496. & 515. \\
\hline 27) & Wire3 & Moly & 480. & 466. & 489. & 467. & 489. \\
\hline 28) & Wire4 & Moly & 519. & 508. & 528. & 508. & 528. \\
\hline 29) & Grafoil3 & GRAFOIL & 190. & 180. & 200 . & 186. & 193. \\
\hline 30) & Grafoil4 & GRAFOIL & 227. & 211. & 240 . & 216. & 233. \\
\hline 31) & Grafoil5 & GRAFOIL & 263. & 234. & 283. & 236. & 274 . \\
\hline 32) & Grafoil8 & GRAFOIL & 463. & 455. & 468. & 457. & 468. \\
\hline 33) & Grafoil9 & GRAFOIL & 462. & 454. & 468. & 456. & 468. \\
\hline 34) & Grafoillo & GRAFOIL & 461. & 454. & 467. & 455. & 467. \\
\hline
\end{tabular}

PROPERTY SUMMARY AT THE AVERAGE PART TEMPERATURE

\begin{tabular}{|c|c|c|c|c|c|}
\hline \multicolumn{2}{|l|}{ Name } & \multirow{2}{*}{ Material } & $\begin{array}{l}\text { Thermal } \\
\text { Cond. } \\
\left(\mathrm{W} / \mathrm{m} \cdot{ }^{\circ} \mathrm{C}\right)\end{array}$ & $\begin{array}{l}\text { Thermal } \\
\text { Exp. } \\
\text { Coeff. } \\
\left(\mu \mathrm{m} / \mathrm{m} \cdot{ }^{\circ} \mathrm{C}\right)\end{array}$ & $\begin{array}{l}\text { Emis } \\
(---)\end{array}$ \\
\hline & -1 & & --------- & --------- & ------ \\
\hline 1) & Housing & $\mathrm{AL}-6061$ & 166.914 & 24.21 & 0.050 \\
\hline 2) & Cap & $A L-6061$ & 169.219 & 0.00 & 0.050 \\
\hline 3) & Grafoill & GRAFOIL & 38.000 & 1.00 & 0.500 \\
\hline 4) & Grafoil2 & GRAFOIL & 38.000 & 1.00 & 0.500 \\
\hline 5) & Grafoil 6 & GRAFOIL & 38.000 & 1.00 & 0.500 \\
\hline 6) & Grafoil7 & GRAFOIL & 38.000 & 1.00 & 0.500 \\
\hline 7) & Thimblela & Ti-6Al4V & 13.593 & 9.97 & 0.377 \\
\hline 8) & Cladl & Zircaloy & 16.486 & 4.83 & 0.699 \\
\hline 9) & Cladl & Zircaloy & 16.406 & 0.00 & 0.699 \\
\hline 10) & Thimble1b & $\mathrm{Ti}-6 \mathrm{Al} 4 \mathrm{~V}$ & 16.004 & 10.19 & 0.403 \\
\hline 11) & Sleeve1 & Moly & 121.951 & 5.14 & 0.070 \\
\hline 13) & Sleevel & Moly & 120.295 & 0.00 & 0.074 \\
\hline 15) & TM1 & $\operatorname{SiC}(\operatorname{Irr})$ & 8.692 & 3.61 & 0.900 \\
\hline 16) & Thimble $2 \mathrm{a}$ & Ti-6Al4V & 15.778 & 10.17 & 0.402 \\
\hline 17) & $\mathrm{Clad} 2$ & Zircaloy & 16.566 & 4.84 & 0.699 \\
\hline 18) & $\mathrm{Clad} 2$ & Zircaloy & 16.473 & 0.00 & 0.699 \\
\hline 19) & Thimble2b & Ti-6Al4V & 16.250 & 10.21 & 0.404 \\
\hline 20) & Sleeve2 & Moly & 120.832 & 5.16 & 0.073 \\
\hline 22) & Sleeve2 & Moly & 119.849 & 0.00 & 0.075 \\
\hline 24) & TM2 & $\operatorname{SiC}(\operatorname{Ir} r)$ & 8.670 & 3.68 & 0.900 \\
\hline 25) & Wire1 & Moly & 122.585 & 0.00 & 0.068 \\
\hline
\end{tabular}




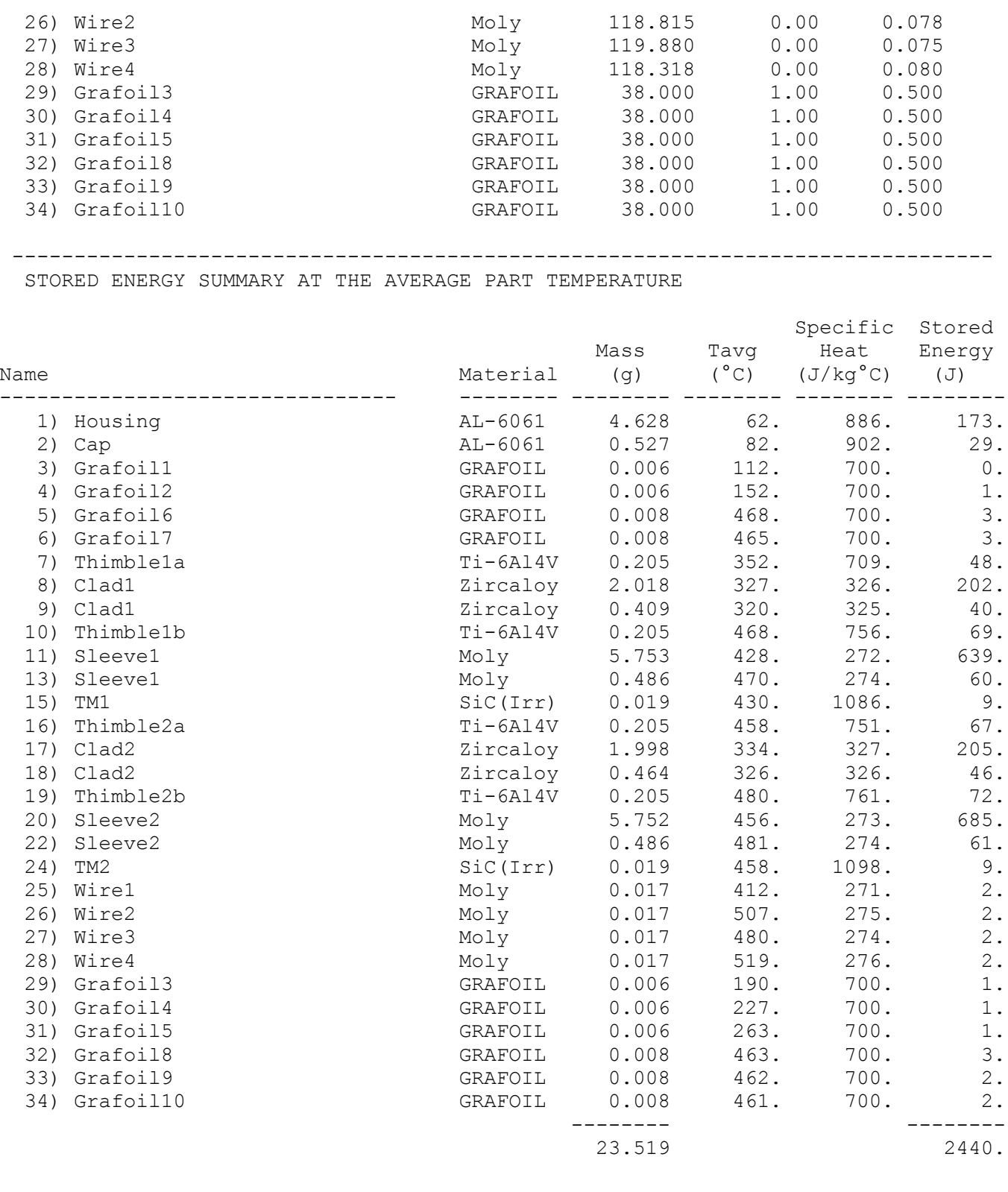

CLAD TO HOUSING GAP REPORTS

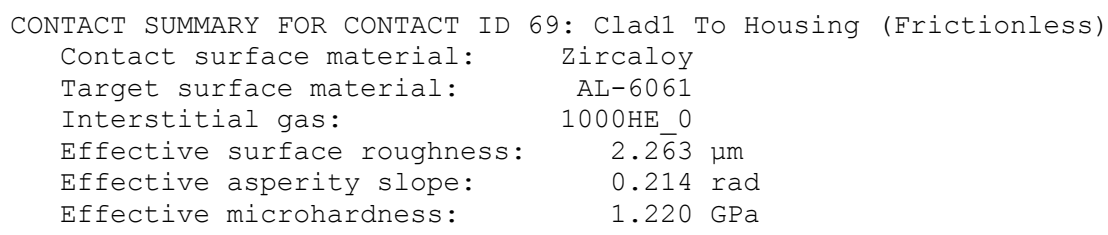


Gap conduction heat flux $\left(\mathrm{kW} / \mathrm{m}^{2}\right)$

Radiation heat flux $\left(\mathrm{kW} / \mathrm{m}^{2}\right)$

Contact conduction heat flux $\left(\mathrm{kW} / \mathrm{m}^{2}\right)$

Total heat flux $\left(\mathrm{kW} / \mathrm{m}^{2}\right)$

Thermal contact conductance $\left(\mathrm{W} / \mathrm{m}^{2} \cdot \mathrm{C}\right)$

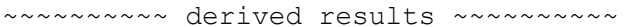

Effective gas gap ( $\mu \mathrm{m})$

Contact thermal jump distance ( $\mu \mathrm{m})$

Target thermal jump distance ( $\mu m)$

Effective contact pressure (MPa)

Pressure index

Gas thermal conductivity $\left(\mathrm{W} / \mathrm{m} \cdot{ }^{\circ} \mathrm{C}\right)$

Solid spot conductance $\left(\mathrm{W} / \mathrm{m}^{2} \cdot \mathrm{C}\right)$

Gas gap conductance $\left(W / \mathrm{m}^{2} \cdot \mathrm{C}\right)$

$$
\begin{array}{r}
438.996 \\
0.000 \\
0.000 \\
438.996 \\
1713.243
\end{array}
$$

117.416

2.115

1. 306

0.000

15.305

0.207

0.000

1714.782
380.777

0.000

0.000

380.777

1648.920

114.700

1.981

1.266

0.000

15.202

0.203

0.000

1650.012
492.468

0.000

0.000

492.468

1774.209

120.068

2.237

1. 340

0.000

15.419

0.210

0.000

1775.841

Contact status codes:

$0=$ open/no heat transfer, 1 =near-field contact

2=closed and sliding, $3=$ closed and sticking

CONTACT SUMMARY FOR CONTACT ID 71: Clad2 TO Housing (Frictionless)

Contact surface material: Zircaloy

Target surface material: AL-6061

Interstitial gas:

\begin{tabular}{|c|c|c|c|}
\hline \multirow[b]{2}{*}{ 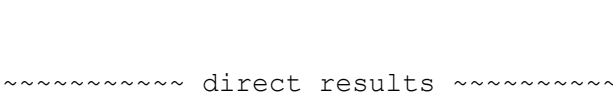 } & Average & Minimum & Maximum \\
\hline & & & \\
\hline Contact status & 1.000 & 1.000 & 1.000 \\
\hline Contact temperature $\left({ }^{\circ} \mathrm{C}\right)$ & 324.193 & 318.141 & 348.043 \\
\hline Target temperature $\left({ }^{\circ} \mathrm{C}\right)$ & 63.704 & 60.608 & 64.321 \\
\hline Geometric gas gap ( $\mu \mathrm{m})$ & 107.381 & 104.844 & 109.835 \\
\hline Contact pressure (MPa) & 0.000 & 0.000 & 0.000 \\
\hline Gap conduction heat flux $\left(\mathrm{kW} / \mathrm{m}^{2}\right)$ & 497.834 & 479.352 & 565.810 \\
\hline Radiation heat flux $\left(\mathrm{kW} / \mathrm{m}^{2}\right)$ & 0.000 & 0.000 & 0.000 \\
\hline Contact conduction heat flux $\left(\mathrm{kW} / \mathrm{m}^{2}\right)$ & 0.000 & 0.000 & 0.000 \\
\hline Total heat flux $\left(\mathrm{kW} / \mathrm{m}^{2}\right)$ & 497.834 & 479.352 & 565.810 \\
\hline $\begin{array}{l}\text { Thermal contact conductance }\left(\mathrm{W} / \mathrm{m}^{2} \cdot \mathrm{C}\right) \\
\sim \sim \sim \sim \sim \sim \sim \sim \sim \text { derived results } \sim \sim \sim \sim \sim \sim \sim \sim\end{array}$ & 1911.116 & 1863.256 & 1995.889 \\
\hline Effective gas gap ( $\mu \mathrm{m})$ & 105.399 & 102.272 & 107.944 \\
\hline Contact thermal jump distance ( $\mu \mathrm{m})$ & 2.148 & 2.114 & 2.287 \\
\hline Target thermal jump distance ( $\mu \mathrm{m})$ & 1.317 & 1.308 & 1.357 \\
\hline Effective contact pressure ( $\mathrm{MPa})$ & 0.000 & 0.000 & 0.000 \\
\hline Pressure index & 15.280 & 15.165 & 15.309 \\
\hline Gas thermal conductivity $\left(\mathrm{W} / \mathrm{m} \cdot{ }^{\circ} \mathrm{C}\right)$ & 0.208 & 0.207 & 0.212 \\
\hline Solid spot conductance $\left(\mathrm{W} / \mathrm{m}^{2} \cdot \mathrm{C}\right)$ & 0.000 & 0.000 & 0.000 \\
\hline Gas gap conductance $\left(W / \mathrm{m}^{2} \cdot \mathrm{C}\right)$ & 1913.033 & 1865.111 & 1998.545 \\
\hline
\end{tabular}

AL-6061
$1000 \mathrm{HE} 0$

Effective surface roughness: $2.2 \overline{6} 3 \mu \mathrm{m}$

Effective asperity slope: $0.214 \mathrm{rad}$

Effective microhardness: $\quad 1.220 \mathrm{GPa}$

Contact status codes:

$0=$ open/no heat transfer, 1 =near-field contact

$2=$ closed and sliding, $3=c l o s e d$ and sticking 


\section{FCZ04:}

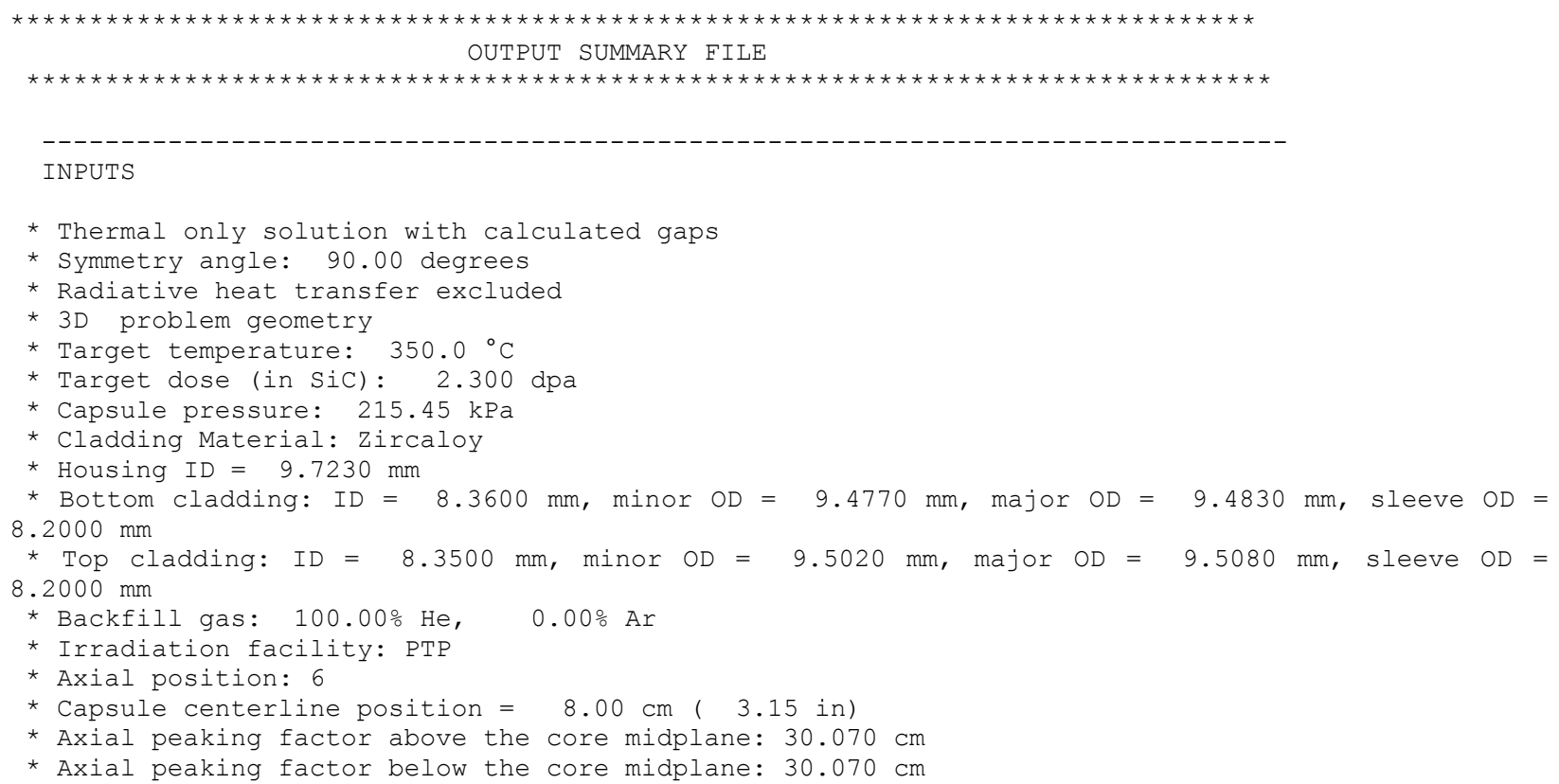

$\begin{array}{rr}\begin{array}{rr}\text { amidplane } \\ \text { (W) }\end{array} & \begin{array}{r}\text { Load } \\ \text { QLocation }\end{array} \\ \text { (W) } \\ 138.2 & 128.9 \\ 15.8 & 13.8 \\ 0.2 & 0.2 \\ 0.2 & 0.2 \\ 0.3 & 0.3 \\ 0.3 & 0.3 \\ 7.3 & 7.1 \\ 93.0 & 89.1 \\ 18.8 & 18.0 \\ 7.3 & 6.9 \\ 234.5 & 224.5 \\ 19.8 & 18.6 \\ 0.7 & 0.6 \\ 7.3 & 6.8 \\ 92.1 & 84.3 \\ 21.4 & 19.6 \\ 7.3 & 6.5 \\ 234.5 & 214.7 \\ 19.8 & 17.7 \\ 0.7 & 0.6 \\ 0.7 & 0.7 \\ 0.7 & 0.6 \\ 0.7 & 0.6 \\ 0.7 & 0.6 \\ 0.2 & 0.2 \\ 0.2 & 0.2 \\ 0.2 & 0.2 \\ & \end{array}$




\begin{tabular}{|c|c|c|c|c|c|}
\hline 32) & Grafoil8 & GRAFOIL & 35000 . & 0.3 & 0.3 \\
\hline 33) & Grafoil9 & GRAFOIL & 35000 . & 0.3 & 0.3 \\
\hline 34) & Grafoillo & GRAFOIL & 35000 . & 0.3 & 0.3 \\
\hline & & & & & \\
\hline
\end{tabular}

CAPSULE TEMPERATURE SUMMARY

\begin{tabular}{|c|c|c|c|c|c|c|c|}
\hline Name & & Material & Tavg & Tmin & $\operatorname{Tmax}$ & T.025 & T.975 \\
\hline 1) & Housing & $\mathrm{AL}-6061$ & 64 & 56. & 82 . & 56. & 79. \\
\hline 2) & Cap & $A L-6061$ & 81. & 80. & 83. & 80. & 83. \\
\hline 3) & Grafoill & GRAFOIL & 119. & 110. & 126. & 117 & 120. \\
\hline 4) & Grafoil2 & GRAFOIL & 162. & 155. & 171. & 161. & 163. \\
\hline 5) & Grafoil 6 & GRAFOIL & 463. & 452. & 469. & 455. & 468. \\
\hline 6) & Grafoil7 & GRAFOIL & 461. & 452. & 464 . & 454 . & 464. \\
\hline 7) & Thimblela & $\mathrm{Ti}-6 \mathrm{Al} 4 \mathrm{~V}$ & 379. & 279. & 425. & 329. & 423. \\
\hline 8) & Cladl & Zircaloy & 345. & 317. & 369. & 322 . & 364. \\
\hline 9) & Cladl & Zircaloy & 337. & 314. & 356. & 318. & 354. \\
\hline 10) & Thimblelb & $\mathrm{Ti}-6 \mathrm{Al} 4 \mathrm{~V}$ & 488. & 358. & 499. & 449 . & 499. \\
\hline 11) & Sleevel & Moly & 456. & 409. & 491. & 415. & 488. \\
\hline 13) & Sleeve1 & Moly & 492. & 488. & 493. & 490 & 493. \\
\hline 15) & TM1 & $\operatorname{SiC}(\operatorname{Irr})$ & 458. & 389. & 492. & 414. & 490. \\
\hline 16) & Thimble $2 \mathrm{a}$ & $\mathrm{Ti}-6 \mathrm{Al} 4 \mathrm{~V}$ & 471. & 339. & 483. & 425 & 481. \\
\hline 17) & $\mathrm{Clad} 2$ & Zircaloy & 333. & 322. & 379. & 326 . & 346 . \\
\hline 18) & $\mathrm{Clad} 2$ & Zircaloy & 325. & 319. & 363. & 321. & 338. \\
\hline 19) & Thimble2b & $\mathrm{Ti}-6 \mathrm{Al} 4 \mathrm{~V}$ & 475. & 354. & 484. & 444 . & 483. \\
\hline 20) & Sleeve2 & Moly & 460. & 453. & 475. & 454 . & 472 . \\
\hline 22) & Sleeve2 & Moly & 477. & 473. & 478. & 474 . & 478. \\
\hline 24) & TM2 & $\operatorname{SiC}(\operatorname{Irr})$ & 462. & 456. & 476. & 456. & 475. \\
\hline 25) & Wire1 & Moly & 444. & 431. & 453. & 432. & 453. \\
\hline 26) & Wire2 & Moly & 529. & 518. & 538. & 518. & 538. \\
\hline 27) & Wire3 & Moly & 491. & 477. & 500. & 478 . & 500. \\
\hline 28) & Wire4 & Moly & 513. & 502. & 521. & 502 . & 521. \\
\hline 29) & Grafoil3 & GRAFOIL & 204. & 193. & 215. & 199. & 207. \\
\hline 30$)$ & Grafoil4 & GRAFOIL & 244. & 227. & 258 . & 232. & 251. \\
\hline 31) & Grafoil5 & GRAFOIL & 283. & 251. & 304 . & 254 . & 294. \\
\hline 32) & Grafoil8 & GRAFOIL & 458. & 451. & 464. & 452 . & 463. \\
\hline 33) & Grafoil9 & GRAFOIL & 457. & 450. & 463. & 451. & 463 \\
\hline 34) & Grafoillo & GRAFOIL & 456. & 449. & 463. & 450 & 462 \\
\hline
\end{tabular}

PROPERTY SUMMARY AT THE AVERAGE PART TEMPERATURE

\begin{tabular}{|c|c|c|c|c|c|}
\hline Name & & Material & $\begin{array}{l}\text { Thermal } \\
\text { Cond. } \\
\left(\mathrm{W} / \mathrm{m} \cdot{ }^{\circ} \mathrm{C}\right)\end{array}$ & $\begin{array}{l}\text { Thermal } \\
\text { Exp. } \\
\text { Coeff. } \\
\left(\mu \mathrm{m} / \mathrm{m} \cdot{ }^{\circ} \mathrm{C}\right)\end{array}$ & $\begin{array}{l}\text { Emis } \\
(---)\end{array}$ \\
\hline & & & --------- & ----- & ------ \\
\hline $\begin{array}{l}\text { 1) } \\
\text { 2) }\end{array}$ & $\begin{array}{l}\text { Housing } \\
\text { Cap }\end{array}$ & $\begin{array}{l}A L-6061 \\
A L-6061\end{array}$ & $\begin{array}{l}16 / .166 \\
169.183\end{array}$ & $\begin{array}{r}24.21 \\
0.00\end{array}$ & $\begin{array}{l}0.050 \\
0.050\end{array}$ \\
\hline 3) & Grafoill & GRAFOIL & 38.000 & 1.00 & 0.500 \\
\hline 4) & Grafoil2 & GRAFOIL & 38.000 & 1.00 & 0.500 \\
\hline 5) & Grafoil 6 & GRAFOIL & 38.000 & 1.00 & 0.500 \\
\hline 6) & Grafoil7 & GRAFOIL & 38.000 & 1.00 & 0.500 \\
\hline 7) & Thimblela & Ti-6Al4V & 14.155 & 10.01 & 0.387 \\
\hline 8) & Cladl & Zircaloy & 16.696 & 4.84 & 0.699 \\
\hline 9) & Clad1 & Zircaloy & 16.612 & 0.00 & 0.699 \\
\hline 10) & Thimble1b & $\mathrm{Ti}-6 \mathrm{Al} 4 \mathrm{~V}$ & 16.403 & 10.23 & 0.404 \\
\hline 11) & Sleevel & Moly & 120.841 & 5.16 & 0.073 \\
\hline 13) & Sleevel & Moly & 119.413 & 0.00 & 0.076 \\
\hline 15) & TM1 & $\operatorname{SiC}(\operatorname{Irr})$ & 8.670 & 3.68 & 0.900 \\
\hline 16) & Thimble2a & Ti-6Al4V & 16.057 & 10.19 & 0.403 \\
\hline 17) & $\mathrm{Clad} 2$ & Zircaloy & 16.559 & 4.84 & 0.699 \\
\hline 18) & $\mathrm{Clad} 2$ & Zircaloy & 16.468 & 0.00 & 0.699 \\
\hline 19) & Thimble2b & $\mathrm{Ti}-6 \mathrm{Al} 4 \mathrm{~V}$ & 16.147 & 10.20 & 0.404 \\
\hline 20) & Sleeve2 & Moly & 120.684 & 5.17 & 0.073 \\
\hline 22) & Sleeve2 & Moly & 120.014 & 0.00 & 0.075 \\
\hline 24) & TM2 & $\operatorname{SiC}(\operatorname{Irr})$ & 8.667 & 3.68 & 0.900 \\
\hline 25) & Wire1 & Moly & 121.301 & 0.00 & 0.072 \\
\hline
\end{tabular}




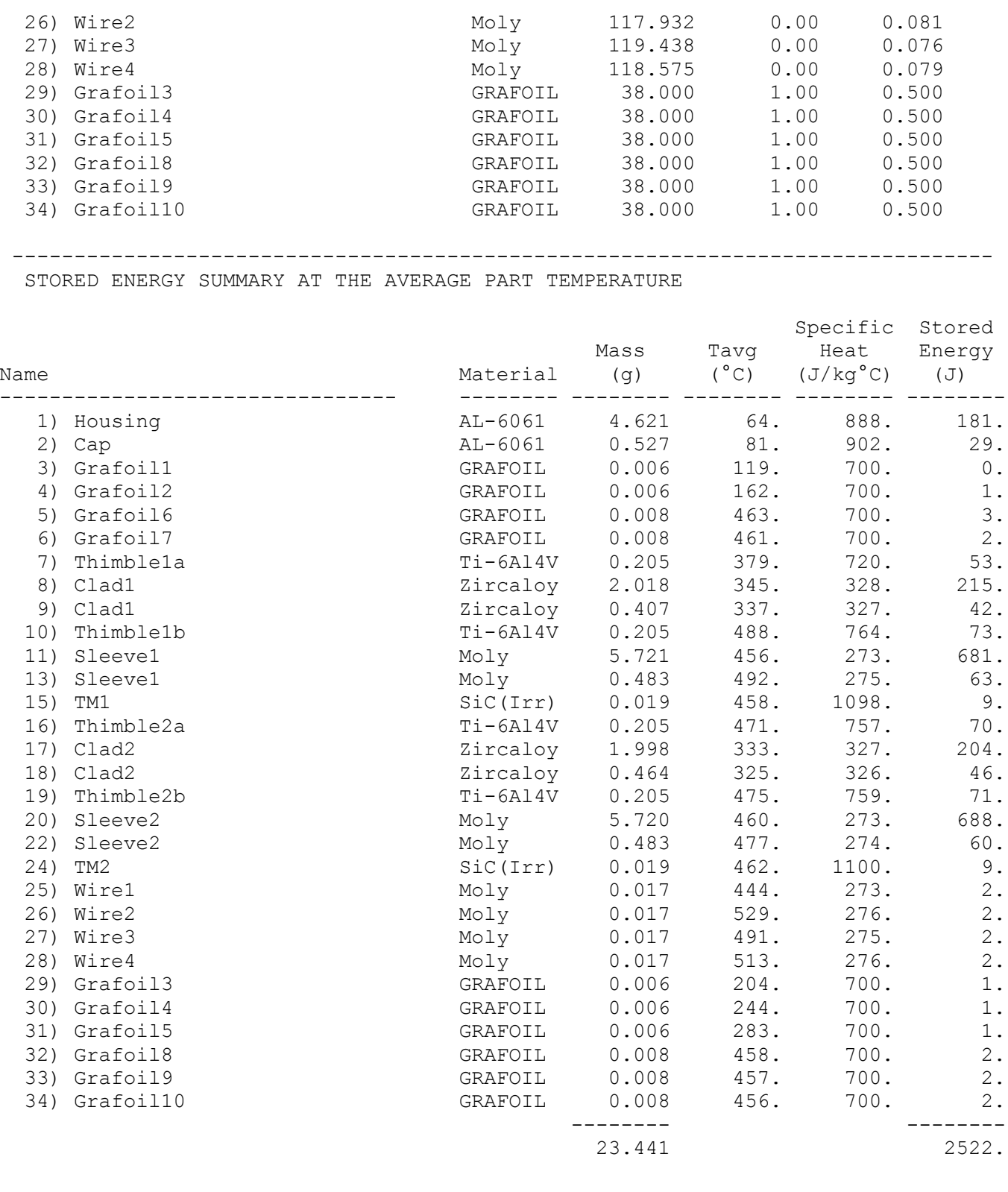

CLAD TO HOUSING GAP REPORTS

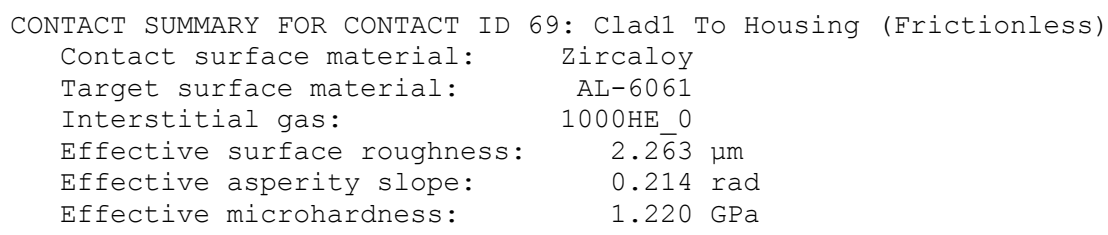


Gap conduction heat flux $\left(\mathrm{kW} / \mathrm{m}^{2}\right)$

Radiation heat flux $\left(\mathrm{kW} / \mathrm{m}^{2}\right)$

Contact conduction heat flux $\left(\mathrm{kW} / \mathrm{m}^{2}\right)$

Total heat flux $\left(\mathrm{kW} / \mathrm{m}^{2}\right)$

Thermal contact conductance $\left(\mathrm{W} / \mathrm{m}^{2} \cdot \mathrm{C}\right)$

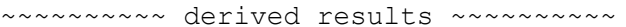

Effective gas gap ( $\mathrm{m}$ )

Contact thermal jump distance ( $\mu \mathrm{m})$

Target thermal jump distance ( $\mu m)$

Effective contact pressure (MPa)

Pressure index

Gas thermal conductivity $\left(\mathrm{W} / \mathrm{m} \cdot{ }^{\circ} \mathrm{C}\right)$

Solid spot conductance $\left(\mathrm{W} / \mathrm{m}^{2} \cdot \mathrm{C}\right)$

Gas gap conductance $\left(W / \mathrm{m}^{2} \cdot \mathrm{C}\right)$

$$
\begin{array}{r}
464.108 \\
0.000 \\
0.000 \\
464.108 \\
1710.975
\end{array}
$$

119.276

2.223

1. 342

0.000

15.222

0.210

0.000

1712.466
413.359

0.000

0.000

413.359

1659.722

117.115

2.104

1. 307

0.000

15.139

0.207

0.000

1660.655
507.860

0.000

0.000

507.860

1757.455

121.393

2.321

1.369

0.000

15.321

0.213

0.000

1759.488

Contact status codes:

$0=$ open/no heat transfer, 1=near-field contact

2=closed and sliding, $\quad 3=$ closed and sticking

CONTACT SUMMARY FOR CONTACT ID 71: Clad2 TO Housing (Frictionless)

Contact surface material: Zircaloy

Target surface material: AL-6061

Interstitial gas: $\quad 1000 \mathrm{HE} 0$

Effective surface roughness: $2.2 \overline{6} 3 \mu \mathrm{m}$

Effective asperity slope: $0.214 \mathrm{rad}$

Effective microhardness: $\quad 1.220 \mathrm{GPa}$

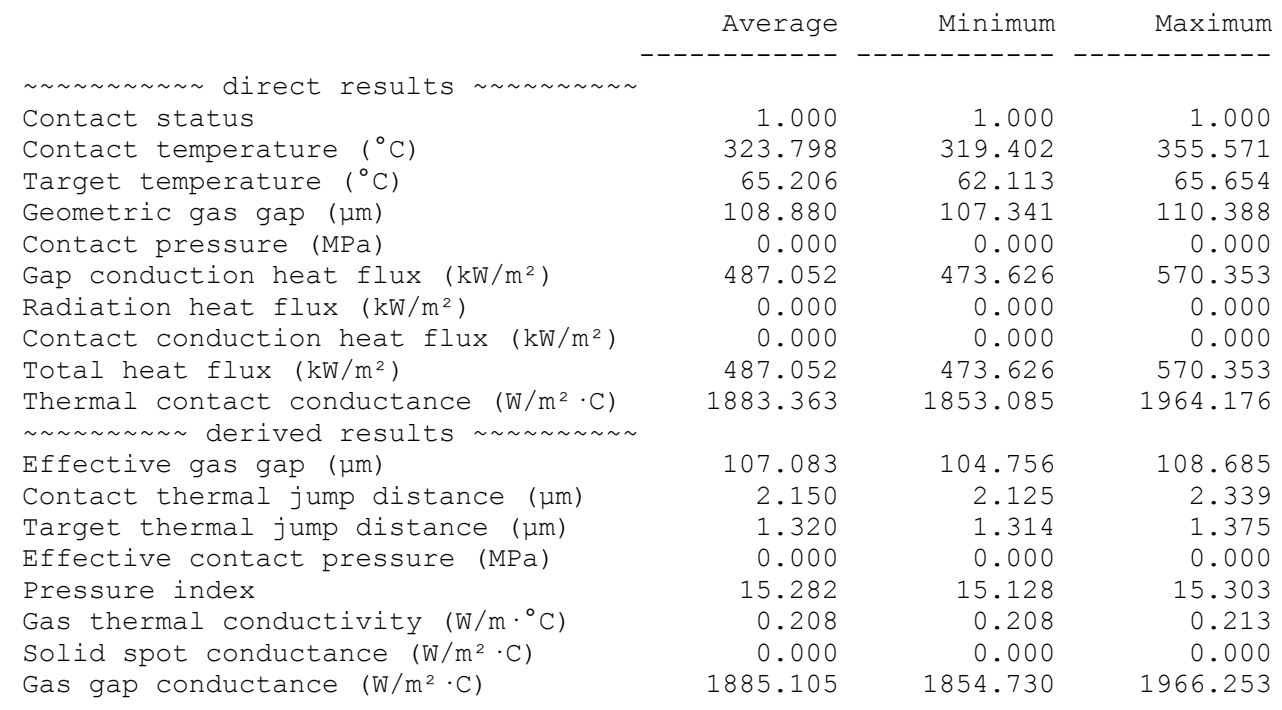

Contact status codes:

$0=$ open/no heat transfer, $1=$ near-field contact

$2=$ closed and sliding, $3=c l o s e d$ and sticking 


\section{FCZ05:}

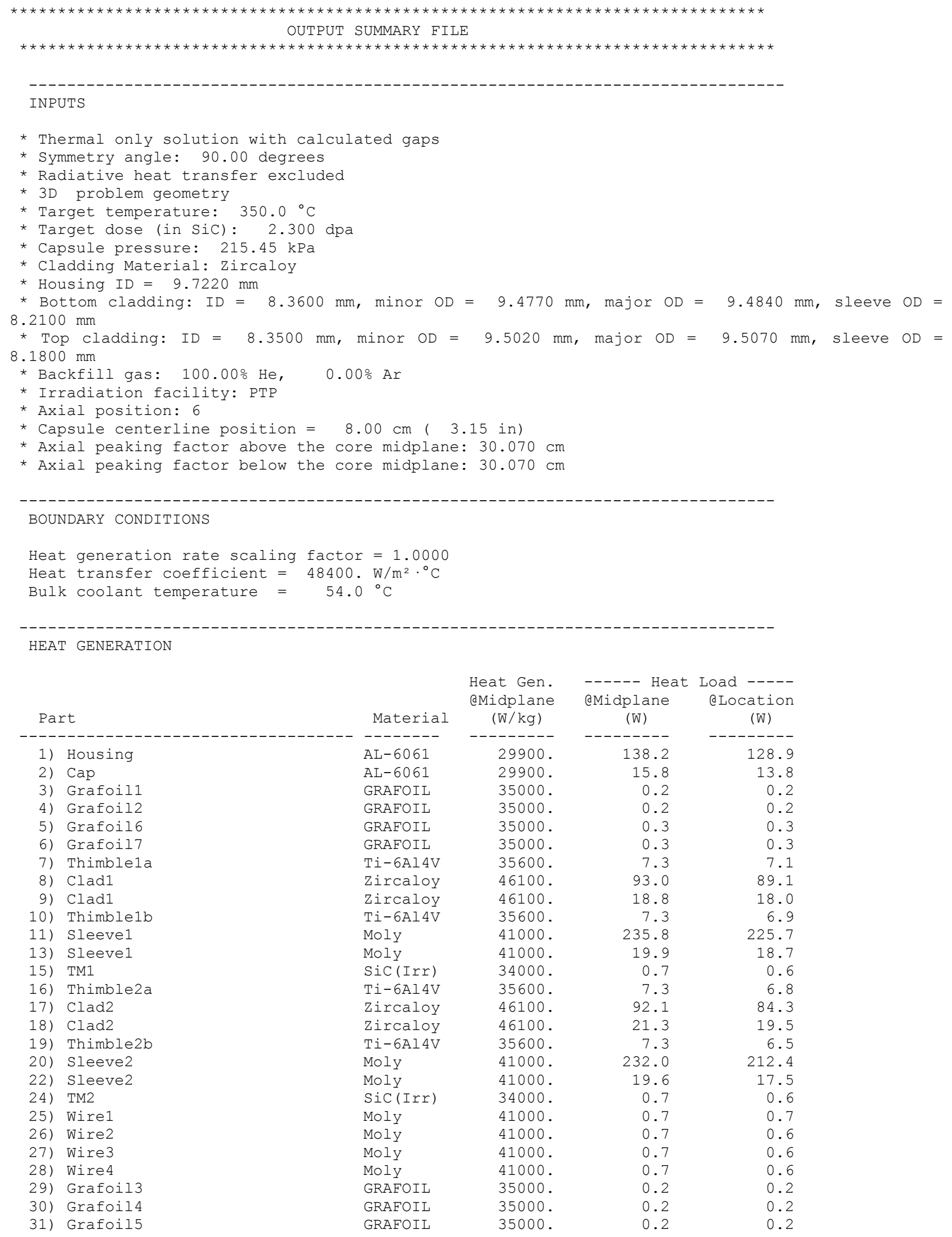




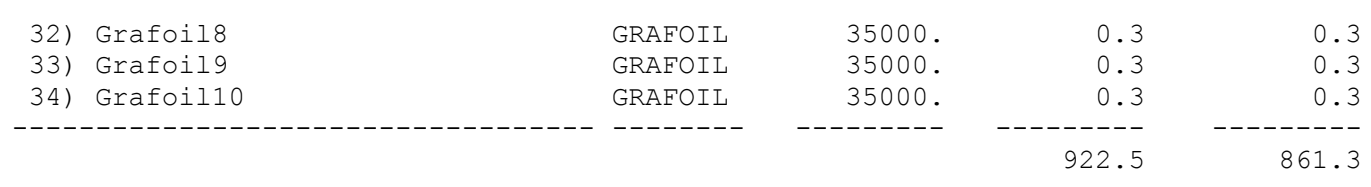

CAPSULE TEMPERATURE SUMMARY

\begin{tabular}{|c|c|c|c|c|c|c|c|}
\hline \multicolumn{2}{|l|}{ Name } & Material & Tavg & Tmin & Tmax & T. 025 & T.975 \\
\hline & Housing & $\begin{array}{l}-------- \\
A T-6061\end{array}$ & $\begin{array}{c}----- \\
64\end{array}$ & ----- & ----- & $\begin{array}{c}----- \\
56\end{array}$ & $\begin{array}{c}----- \\
79\end{array}$ \\
\hline $\begin{array}{l}\text { 1) } \\
\text { 2) }\end{array}$ & $\begin{array}{l}\text { Housing } \\
\text { Cap }\end{array}$ & $\begin{array}{l}\mathrm{AL}-6061 \\
\mathrm{AL}-6061\end{array}$ & $\begin{array}{l}64 . \\
81 .\end{array}$ & $\begin{array}{l}56 . \\
80 .\end{array}$ & $\begin{array}{l}82 . \\
83 .\end{array}$ & $\begin{array}{l}56 . \\
80 .\end{array}$ & $\begin{array}{l}79 . \\
83 .\end{array}$ \\
\hline 3) & Grafoill & GRAFOIL & 118. & 109. & 125. & 117. & 119. \\
\hline 4) & Grafoil2 & GRAFOIL & 161. & 154. & 169. & 160 & 162. \\
\hline 5) & Grafoil6 & GRAFOIL & 471. & 459. & 477. & 462 . & 475. \\
\hline 6) & Grafoil7 & GRAFOIL & 468. & 459. & 472. & 461. & 472. \\
\hline 7) & Thimblela & $\mathrm{Ti}-6 \mathrm{Al} 4 \mathrm{~V}$ & 376. & 277. & 421. & 327. & 419. \\
\hline 8) & Clad1 & Zircaloy & 345. & 316. & 371. & 322 . & 366. \\
\hline 9) & Clad1 & Zircaloy & 338. & 313. & 358. & 318. & 356. \\
\hline 10) & Thimblelb & Ti-6Al4V & 487. & 356. & 497. & 448 & 496. \\
\hline 11) & Sleevel & Moly & 452. & 405. & 488. & 411. & 484. \\
\hline 13) & Sleevel & Moly & 489. & 485. & 491. & 487. & 490. \\
\hline 15) & TM1 & $\operatorname{SiC}(\operatorname{Irr})$ & 453. & 386. & 489. & 410. & 487. \\
\hline 16) & Thimble2a & $\mathrm{Ti}-6 \mathrm{Al} 4 \mathrm{~V}$ & 475. & 337. & 486. & 426. & 484. \\
\hline 17) & $\mathrm{Clad} 2$ & Zircaloy & 330. & 320. & 377. & 323. & 343. \\
\hline 18) & $\mathrm{Clad} 2$ & Zircaloy & 322. & 317. & 361. & 318. & 335. \\
\hline 19) & Thimble2b & $\mathrm{Ti}-6 \mathrm{Al} 4 \mathrm{~V}$ & 483. & 357. & 492. & 451. & 492. \\
\hline 20) & Sleeve2 & Moly & 468. & 462. & 484. & 463. & 481. \\
\hline 22) & Sleeve2 & Moly & 485 . & 481. & 487. & 483. & 487. \\
\hline 24) & TM2 & $\operatorname{SiC}(\operatorname{Irr})$ & 470. & 465. & 485. & 465. & 483. \\
\hline 25) & Wire1 & Moly & 441. & 427. & 450. & 428. & 450. \\
\hline 26) & Wire2 & Moly & 527. & 515. & 535. & 516. & 535. \\
\hline 27) & Wire3 & Moly & 497. & 482. & 506. & 483. & 506. \\
\hline 28) & Wire4 & Moly & 522. & 511. & 530. & 511. & 530. \\
\hline 29) & Grafoil3 & GRAFOIL & 203. & 192. & 213. & 198. & 206. \\
\hline 30) & Grafoil4 & GRAFOIL & 242. & 225. & 256. & 230. & 249. \\
\hline 31) & Grafoil5 & GRAFOIL & 281. & 249. & 302. & 252 . & 292. \\
\hline 32) & Grafoil8 & GRAFOIL & 466. & 458. & 471. & 459. & 471. \\
\hline 33) & Grafoil9 & GRAFOIL & 464. & 457. & 470. & 458. & 470. \\
\hline 34) & Grafoillo & GRAFOIL & 464. & 456. & 470. & 458. & 470. \\
\hline
\end{tabular}

PROPERTY SUMMARY AT THE AVERAGE PART TEMPERATURE

\begin{tabular}{|c|c|c|c|c|c|}
\hline \multicolumn{2}{|l|}{ Name } & \multirow{2}{*}{ Material } & $\begin{array}{l}\text { Thermal } \\
\text { Cond. } \\
\left(\mathrm{W} / \mathrm{m} \cdot{ }^{\circ} \mathrm{C}\right)\end{array}$ & $\begin{array}{l}\text { Thermal } \\
\text { Exp. } \\
\text { Coeff. } \\
\left(\mu \mathrm{m} / \mathrm{m} \cdot{ }^{\circ} \mathrm{C}\right)\end{array}$ & $\begin{array}{l}\text { Emis } \\
(---)\end{array}$ \\
\hline & -1 & & --------- & --------- & ------ \\
\hline 1) & Housing & $\mathrm{AL}-6061$ & 167.164 & 24.21 & 0.050 \\
\hline 2) & Cap & $A L-6061$ & 169.183 & 0.00 & 0.050 \\
\hline 3) & Grafoill & GRAFOIL & 38.000 & 1.00 & 0.500 \\
\hline 4) & Grafoil2 & GRAFOIL & 38.000 & 1.00 & 0.500 \\
\hline 5) & Grafoil 6 & GRAFOIL & 38.000 & 1.00 & 0.500 \\
\hline 6) & Grafoil7 & GRAFOIL & 38.000 & 1.00 & 0.500 \\
\hline 7) & Thimblela & Ti-6Al4V & 14.089 & 10.01 & 0.386 \\
\hline 8) & Cladl & Zircaloy & 16.703 & 4.84 & 0.699 \\
\hline 9) & Cladl & Zircaloy & 16.619 & 0.00 & 0.699 \\
\hline 10) & Thimble1b & $\mathrm{Ti}-6 \mathrm{Al} 4 \mathrm{~V}$ & 16.386 & 10.22 & 0.404 \\
\hline 11) & Sleeve1 & Moly & 121.020 & 5.16 & 0.072 \\
\hline 13) & Sleevel & Moly & 119.522 & 0.00 & 0.076 \\
\hline 15) & TM1 & $\operatorname{SiC}(\operatorname{Irr})$ & 8.674 & 3.67 & 0.900 \\
\hline 16) & Thimble $2 \mathrm{a}$ & Ti-6Al4V & 16.147 & 10.20 & 0.404 \\
\hline 17) & $\mathrm{Clad} 2$ & Zircaloy & 16.522 & 4.84 & 0.699 \\
\hline 18) & $\mathrm{Clad} 2$ & Zircaloy & 16.433 & 0.00 & 0.699 \\
\hline 19) & Thimble2b & Ti-6Al4V & 16.318 & 10.22 & 0.404 \\
\hline 20) & Sleeve2 & Moly & 120.352 & 5.17 & 0.074 \\
\hline 22) & Sleeve2 & Moly & 119.673 & 0.00 & 0.076 \\
\hline 24) & TM2 & $\operatorname{SiC}(\operatorname{Ir} r)$ & 8.661 & 3.70 & 0.900 \\
\hline 25) & Wire1 & Moly & 121.448 & 0.00 & 0.071 \\
\hline
\end{tabular}




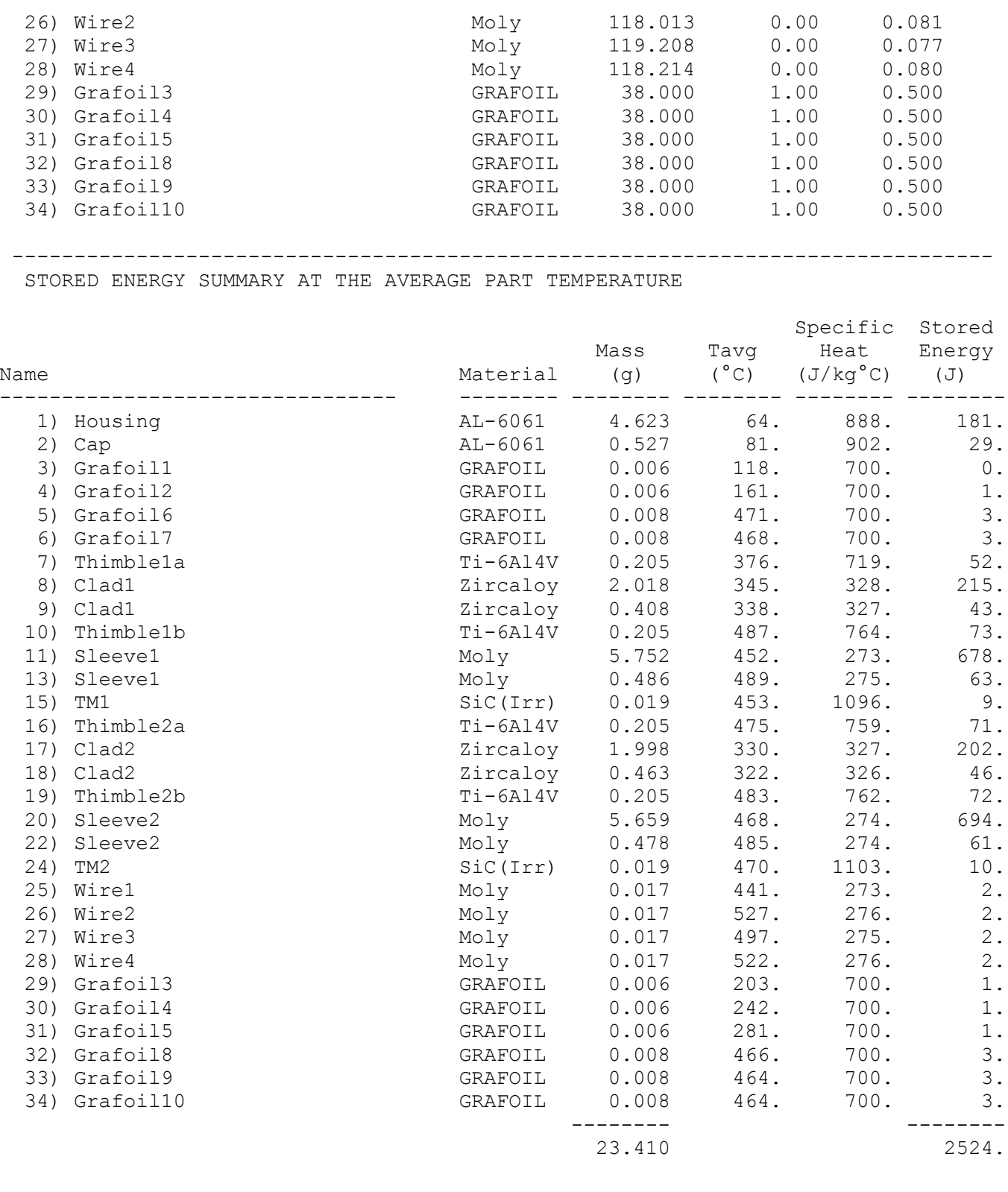

CLAD TO HOUSING GAP REPORTS

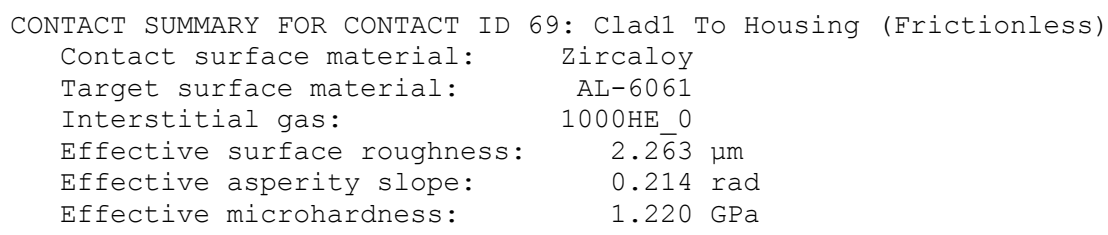


Gap conduction heat flux $\left(\mathrm{kW} / \mathrm{m}^{2}\right)$

Radiation heat flux $\left(\mathrm{kW} / \mathrm{m}^{2}\right)$

Contact conduction heat flux $\left(\mathrm{kW} / \mathrm{m}^{2}\right)$

Total heat flux $\left(\mathrm{kW} / \mathrm{m}^{2}\right)$

Thermal contact conductance $\left(\mathrm{W} / \mathrm{m}^{2} \cdot \mathrm{C}\right)$

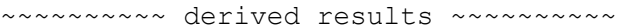

Effective gas gap ( $\mathrm{m}$ )

Contact thermal jump distance ( $\mu \mathrm{m})$

Target thermal jump distance ( $\mu m)$

Effective contact pressure (MPa)

Pressure index

Gas thermal conductivity $\left(\mathrm{W} / \mathrm{m} \cdot{ }^{\circ} \mathrm{C}\right)$

Solid spot conductance $\left(\mathrm{W} / \mathrm{m}^{2} \cdot \mathrm{C}\right)$

Gas gap conductance $\left(W / \mathrm{m}^{2} \cdot \mathrm{C}\right)$
467.942

0.000

0.000

467.942

1722.283

118.523

2.227

1. 343

0.000

15.219

0.210

0.000

1723.787
413.555

0.000

0.000

413.555

1665.325

116.092

2. 103

1.307

0.000

15.131

0.207

0.000

1666.316
515.045

0.000

0.000

515.045

1774.236

120.909

2.331

1. 371

0.000

15.324

0.213

0.000

1776.233

Contact status codes:

$0=$ open/no heat transfer, 1 =near-field contact

2=closed and sliding, $3=$ closed and sticking

CONTACT SUMMARY FOR CONTACT ID 71: Clad2 TO Housing (Frictionless)

Contact surface material: Zircaloy

Target surface material: AL-6061

Interstitial gas: $1000 \mathrm{HE} 0$

Effective surface roughness: $2.2 \overline{6} 3 \mu \mathrm{m}$

Effective asperity slope: $0.214 \mathrm{rad}$

Effective microhardness: $\quad 1.220 \mathrm{GPa}$

\begin{tabular}{|c|c|c|c|}
\hline \multirow[b]{2}{*}{$\sim \sim \sim \sim \sim \sim \sim \sim \sim \sim \sim$ direct results $\sim \sim \sim \sim \sim \sim \sim \sim \sim$} & Average & Minimum & Maximum \\
\hline & & & \\
\hline Contact status & 1.000 & 1.000 & 1.000 \\
\hline Contact temperature $\left({ }^{\circ} \mathrm{C}\right)$ & 320.815 & 316.753 & 353.728 \\
\hline Target temperature $\left({ }^{\circ} \mathrm{C}\right)$ & 65.099 & 62.061 & 65.516 \\
\hline Geometric gas gap ( $\mu \mathrm{m})$ & 108.630 & 107.340 & 109.902 \\
\hline Contact pressure (MPa) & 0.000 & 0.000 & 0.000 \\
\hline Gap conduction heat flux $\left(\mathrm{kW} / \mathrm{m}^{2}\right)$ & 481.420 & 469.179 & 566.848 \\
\hline Radiation heat flux $\left(\mathrm{kW} / \mathrm{m}^{2}\right)$ & 0.000 & 0.000 & 0.000 \\
\hline Contact conduction heat flux $\left(\mathrm{kW} / \mathrm{m}^{2}\right)$ & 0.000 & 0.000 & 0.000 \\
\hline Total heat flux $\left(\mathrm{kW} / \mathrm{m}^{2}\right)$ & 481.420 & 469.179 & 566.848 \\
\hline $\begin{array}{l}\text { Thermal contact conductance }\left(\mathrm{W} / \mathrm{m}^{2} \cdot \mathrm{C}\right) \\
\sim \sim \sim \sim \sim \sim \sim \sim \sim \text { derived results } \sim \sim \sim \sim \sim \sim \sim \sim\end{array}$ & 1882.514 & 1856.248 & 1961.778 \\
\hline Effective gas gap ( $\mu \mathrm{m})$ & 106.892 & 104.785 & 108.257 \\
\hline Contact thermal jump distance ( $\mu \mathrm{m})$ & 2.132 & 2.110 & 2.328 \\
\hline Target thermal jump distance ( $\mu \mathrm{m})$ & 1.315 & 1.309 & 1.372 \\
\hline Effective contact pressure ( $\mathrm{MPa})$ & 0.000 & 0.000 & 0.000 \\
\hline Pressure index & 15.296 & 15.137 & 15.315 \\
\hline Gas thermal conductivity $\left(\mathrm{W} / \mathrm{m} \cdot{ }^{\circ} \mathrm{C}\right)$ & 0.208 & 0.207 & 0.213 \\
\hline Solid spot conductance $\left(\mathrm{W} / \mathrm{m}^{2} \cdot \mathrm{C}\right)$ & 0.000 & 0.000 & 0.000 \\
\hline Gas gap conductance $\left(W / \mathrm{m}^{2} \cdot \mathrm{C}\right)$ & 1883.953 & 1857.333 & 1963.933 \\
\hline
\end{tabular}

Contact status codes:

$0=$ open/no heat transfer, 1 =near-field contact

$2=\mathrm{closed}$ and sliding, $3=\mathrm{closed}$ and sticking 